\title{
SZENNYVÍZISZAPOK \\ BIOLÓGIAI LEBONTHATÓSÁGÁNAK NÖVELÉSE MIKROHULLÁMÚ ELŐKEZELÉSSEL
}

$\mathrm{PhD}$ értekezés

\section{Beszédes Sándor}

\author{
Témavezető: \\ Dr. Hodúr Cecilia \\ egyetemi tanár, $P h D$ \\ Társ-témavezető: \\ Dr. Keszthelyi-Szabó Gábor \\ egyetemi tanár, az MTA Doktora
}

Környezettudományi Doktori Iskola

Szegedi Tudományegyetem

Szeged

2014 


\section{TARTALOMJEGYZÉK}

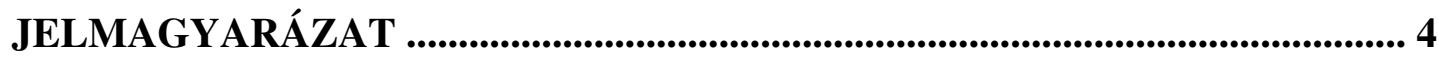

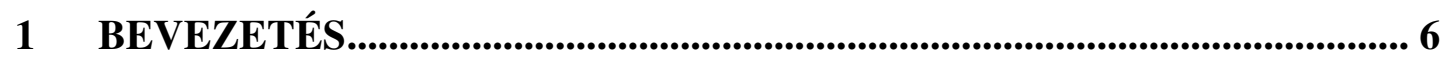

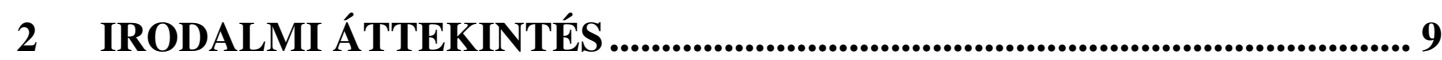

2.1 A mikrohullámú sugárzás és hőkeltési sajátosságai .................................. 9

2.1.1 A mikrohullámú sugárzás fizikai alapjai .......................................... 9

2.1.2 A mikrohullámú hőkeltés alapjai .................................................... 14

2.2 A mikrohullámú sugárzás alkalmazása és hatásai .................................. 22

2.2.1 A mikrohullám alkalmazási területei............................................... 22

2.2.2 A mikrohullámú sugárzás hatásai a biológiai rendszerekre......... 27

2.2.3 A mikrohullámú sugárzás nem-termikus hatásai.......................... 29

2.3 Mikrohullámú technika alkalmazása a szennyvíziszap-kezelésben.... 33

2.3.1 Szennyvíziszapok és kezelési lehetőségeik ........................................ 33

2.3.2 A mikrohullámú iszapkezelés eddigi eredményei........................... 40

2.3.2.1 Iszapszerkezetre gyakorolt hatások .............................................40

2.3.2.2 Az anaerob fermentáció hatékonyságára gyakorolt hatások ....45

3 CÉLKITÜZÉS ............................................................................................. 48

4 ANYAGOK ÉS MÓDSZEREK............................................................... 49

4.1 A kísérletekhez felhasznált iszapok.............................................................. 49

4.2 Mikrohullámú kezelések ................................................................................. 50

4.3 Dielektromos jellemzők meghatározása .................................................... 52

4.4 Vizsgálati és analitikai módszerek ............................................................ 53

4.4.1 Biokémiai oxigénigény mérése ......................................................... 53

4.4.2 Kémiai oxigénigény mérése............................................................. 54

4.4.3 Szárazanyag tartalom és összes illékony szilárd anyag.................. 55

4.4.4 Anaerob rothasztási tesztek .............................................................. 55

4.4.5 Mikrobiológiai vizsgálatok................................................................... 56

5 EREDMÉNYEK ÉS ÉRTÉKELÉSÜK ….................................................. 57

5.1 A vízoldható szervesanyagfrakció változásai ........................................... 57

5.1.1 Termikus iszapkezelési módszerek összehasonlító vizsgálata ..... 57

5.1.2 Mikrohullámú múveleti paraméterek és a szervesanyag oldhatóság összefüggése .................................................................................................................. 61 
5.2 A biológiailag bontható szervesanyagfrakció változásai..................... 67

5.2.1 Termikus és mikrohullámú eljárás összehasonlító vizsgálata ..... 67

5.2.2 A mikrohullámú eljárás kezelési körülményeinek hatása ............ 70

5.2.3 A biológiailag bontható komponensek relatív arányának változása ................................................................................................ 72

5.3 Mikrohullámú iszapkezelés múveleti paramétereinek optimálása ..... 77

5.3.1 Mikrohullámú kezelés jellemzésére alkotott paraméterek .......... 77

5.3.2 Mikrohullámú kezelés múveleti paramétereinek optimálása...... 80

5.4 A mikrohullámú előkezelés hatása az anaerob fermentációra............. 86

5.4.1 Az illékony komponensek változása.............................................. 86

5.4.2 Mezofil rothasztási tesztek eredményei ........................................... 88

5.4.3 A rothasztást megelőző mikrohullámú kezelések energiahasznosulási mutatói.

5.5 Az iszap szervesanyag frakciójában bekövetkező változások és a

dielektromos jellemzők összefüggése ...................................................................... 100

5.6 Költségbecslés és megtérülési idő számítása........................................... 106

6 ÖSSZEFOGLALÁS ........................................................................................ 111

7 ÚJ TUDOMÁNYOS EREDMÉNYEK ....................................................... 114

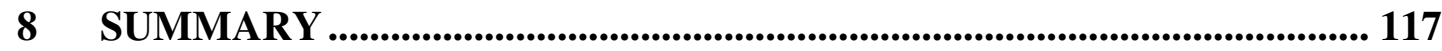

9 IRODALOMJEGYZÉK …................................................................................ 120

10 A DOKTORI ÉRTEKEZÉS ALAPJÁT KÉPEZŐ KÖZLEMÉNYEK... 127

KÖSZÖNETNYILVÁNÍTÁS .............................................................................. 129 


\section{JELMAGYARÁZAT}

\begin{tabular}{|c|c|c|}
\hline$\alpha$ & csillapítási tényező & {$[-]$} \\
\hline B & mágneses indukció & {$\left[\mathrm{N} \mathrm{s}(\mathrm{C} \mathrm{m})^{-1}\right]$} \\
\hline BDI & biodegradation index, biodegradálhatósági index & {$[-]$} \\
\hline $\mathrm{BOD}(\mathrm{BOI})$ & biochemyal oxygen demand, biokémiai oxigénigény & {$\left[\mathrm{kgm}^{-3}\right]$} \\
\hline $\mathrm{COD}(\mathrm{KOI})$ & chemycal oxygen demand, kémiai oxigénigény & {$\left[\mathrm{kgm}^{-3}\right]$} \\
\hline$c_{p}$ & állandó nyomáson mért fajhő & {$\left[\mathrm{kJkg}^{-1} \mathrm{~K}^{-1}\right]$} \\
\hline $\mathrm{c}_{\mathrm{v}(\mathrm{CH} 4)}$ & metánkoncentráció a biogázban & {$[\mathrm{V} / \mathrm{V} \%]$} \\
\hline $\mathrm{D}$ & elektromos eltolás & {$\left[\mathrm{C} \mathrm{m}^{-2}\right]$} \\
\hline$d_{p}$ & penetrációs mélység & {$[\mathrm{m}]$} \\
\hline $\mathrm{E}$ & elektromos térerősség & {$\left[\mathrm{V} \mathrm{m}^{-1}\right]$} \\
\hline$\varepsilon$ & permittivitás & {$[-]$} \\
\hline$\varepsilon^{\prime}$ & dielektromos állandó & {$[-]$} \\
\hline$\varepsilon "$ & dielektromos veszteségi tényező & {$[-]$} \\
\hline EPS & \multicolumn{2}{|c|}{ extracellular polymerc substance, sejteen kívüli polimer állomány } \\
\hline f & frekvencia & {$[\mathrm{Hz}]$} \\
\hline$\phi$ & magnetron villamosenergia transzformációs hatásfoka & {$[-]$} \\
\hline FÁ & földgáz bruttó díja & {$[\mathrm{Ft} / \mathrm{MJ}]$} \\
\hline $\mathrm{H}$ & mágneses térerősség & {$\left[\mathrm{A} \mathrm{m}^{-1}\right]$} \\
\hline$\eta$ & dinamikai viszkozitás & [Pas $]$ \\
\hline I & szakaszos mikrohullámú kezelés sugárzási idő & {$[\%]$} \\
\hline IMWE & \multicolumn{2}{|c|}{$\begin{array}{l}\text { irradiated microwave energy, közölt mikrohullámú energia } \\
\qquad\left[\mathrm{kJg}^{-1}\right]\end{array}$} \\
\hline $\mathrm{J}$ & áramsűrüség & {$\left[\mathrm{A} \mathrm{m}^{-2}\right]$} \\
\hline $\mathrm{k}$ & fajlagos iszapkezelési költség & {$[\mathrm{Ft} / \mathrm{kg}]$} \\
\hline K1 & teljesítménydíj & {$[\mathrm{Ft} / \mathrm{kW}]$} \\
\hline K2 & fogyasztási díj & {$[\mathrm{Ft} / \mathrm{kWh}]$} \\
\hline $\mathrm{K}_{\mathrm{V}}$ & havi teljes üzemeltetési költség & [Ft/hónap] \\
\hline$\lambda$ & hullámhossz & {$[\mathrm{m}]$} \\
\hline$\mu$ & mágneses permeabilitás & {$\left[\mathrm{H} \mathrm{m}^{-1}\right]$} \\
\hline MWPL & \multicolumn{2}{|c|}{ microwave power level, mikrohullámú teljesítmény-intenzitás $\left[\mathrm{Wg}^{-1}\right]$} \\
\hline PCOD & \multicolumn{2}{|c|}{$\begin{array}{l}\text { particular chemycal oxygen demand, szilárd fázisban mért kémiai } \\
\text { oxigénigény }\end{array}$} \\
\hline$P_{d}$ & disszipált teljesítmény & {$[\mathrm{W}]$} \\
\hline$P_{f}$ & fajlagos teljesítmény & {$[\mathrm{W}]$} \\
\hline
\end{tabular}




\begin{tabular}{|c|c|c|}
\hline $\mathrm{P}_{\mathrm{m}}$ & magnetron teljesítmény & {$[\mathrm{W}]$} \\
\hline q & metán energiatartalma & {$\left[\mathrm{MJ} / \mathrm{m}^{3}\right]$} \\
\hline $\mathrm{q}_{\mathrm{m}}$ & tömegáram & {$\left[\mathrm{gs}^{-1}\right]$} \\
\hline$\rho$ & sürüség & {$\left[\mathrm{kgm}^{-3}\right]$} \\
\hline $\mathrm{R}$ & nyereség & {$[\mathrm{Ft}]$} \\
\hline $\mathrm{R}^{\prime}$ & nettó nyereség & {$[\mathrm{Ft}]$} \\
\hline$\sigma$ & elektromos vezetőképesség & {$\left[\mathrm{S} \mathrm{m}^{-1}\right]$} \\
\hline SCOD & \multicolumn{2}{|c|}{$\begin{array}{l}\text { soluble chemycal oxygen demand, vízoldható fázisban mért kémiai } \\
\text { oxigénigény }\end{array}$} \\
\hline SLI & solubility index, szervesanyag oldhatósági index & {$[-]$} \\
\hline$\tau_{\text {megt }}$ & megtérülési idő & [hónap] \\
\hline$\tau_{\text {üz }}$ & napi üzemelési idő & [óra] \\
\hline TCOD & \multicolumn{2}{|c|}{$\begin{array}{l}\text { total chemycal oxygen demand, kémiai oxigénigény a teljes iszapmátrixból } \\
\qquad\left[\mathrm{kgm}^{-3}\right]\end{array}$} \\
\hline TS & total solids, száranyagtartalom & {$[\mathrm{m} / \mathrm{m} \%]$} \\
\hline$Y_{\text {biogáz }}$ & fajlagos biogázkitermelési mutató & {$\left[\mathrm{mL} \mathrm{g}^{-1}\right]$} \\
\hline $\mathrm{V}_{\mathrm{CH} 4}$ & képződő metán térfogat a & {$[\mathrm{L}]$} \\
\hline VS & volatile solids, illékonyanyag szárazanyagtartalom & {$[\mathrm{m} / \mathrm{m} \%]$} \\
\hline
\end{tabular}




\section{BEVEZETÉS}

A szennyvíztisztítási technológiák egyre szélesebb körben való terjedése, és a technológiák hatékonyságának növekedése, a kibocsátott tisztított víz minőségi paramétereinek folyamatos javulását okozza. A vízminőség javulásával és a tisztított szennyvíz arányának növekedésével párhuzamosan azonban a kommunális szennyvíztisztítók és egyes ipari szennyvíztisztító létesítmények üzemeltetői egyre gyakrabban szembesülnek a keletkező szennyvíziszapok kezelésének - ártalmatlanítás, tárolás, szállítás, hasznosítás - problémájával.

Az üzemi gyakorlatban a teljes üzemeltetési költségeket tekintve a szennyvíziszap kezelésének költségeit a szennyvízkezelés költségeivel közel azonos súllyal kell figyelembe venni, ezért a szennyvíziszap kezelés és hasznosítás a kutatás-fejlesztési munkák területén egyre nagyobb hangsúlyt kap.

A szennyvíziszap hasznosítása legtöbbször a mezőgazdasági területeken komposztálás, vagy anaerob fermentációs eljárások keretében történik. Környezetterhelési, környezetbiztonsági, higiénia és gazdasági megfontolások alapján is célszerünek látszik az iszapok előkezelése. A hasznosítási eljárások során egyrészt biztosítani kell, hogy a környezeti elemekkel kapcsolatba kerülő iszap patogén mikroorganizmusoktól és toxikus komponensektől mentes legyen, továbbá a lerakás vagy szállítás költségessége miatt a térfogata csökkenjen és a tárolás során a benne végbemenő mikrobiológiai és biokémiai folyamatok kockázatot ne jelentsenek, illetve a további hasznosítás hatásfoka megfelelő legyen.

A lehetséges kezelési eljárások közül a termikus módszereket alkalmazzák a legszélesebb körben. A termikus kezelések legfontosabb célja a vízteleníthetőség javítása, vagy a nedvességtartalom csökkentése, az iszapok büzterhelésének mérséklése és a mikrobiális kockázatuk csökkentése, valamint a rothaszthatóságuk javítása. A termikus iszapkezelés és előkezelésre vonatkozó több évtizedes kedvező tapasztalatok alátámasztották a módszer alkalmazhatóságát.

A hagyományos hőközlési eljárások alternatívájaként az utóbbi évtizedekben egyre többet vizsgálják a mikrohullámú energiaközléses müveleteket. A mikrohullámú sugárzás a speciális hőkeltési tulajdonságai révén, továbbá a változó, nagyfrekvenciás térben létrejövő ún. nem-termikus hatások miatt egyre szélesebb körben vált felhasználhatóvá. Ezek a 
speciális tulajdonságok például: az anyag magbelsejében történő hőfejlődés, a hőmérsékleti és nedvesség gradiens-vektorok azonos iránya (magbelsőtől a felszíni felé), az eltérő dielektromos tulajdonságok miatt fellépő szelektív felmelegítés jelensége a többkomponensű rendszerekben, a nagy energiasürűség miatti gyors felmelegítő képesség stb.

A mikrohullám alkalmazási területei kiterjednek a nedvesség-elvonási müveletekre, a gyógyászatra, élelmiszeripari felhasználásra, kémiai szintézisekre és egyes környezetvédelmi és hulladék-hasznosítási eljárásokra is. A mikrohullám széles körü felhasználása és potenciális alkalmazási lehetőségeinek kutatásai ellenére, az ipari hasznosítás lehetőségeit megteremtő tapasztalatok csak kismértékben állnak rendelkezésünkre.

A doktori értekezésemben a mikrohullámú energiaközléses szennyvíziszap kezelés vizsgálatával foglalkozom. A mikrohullámú iszapkezelésre vonatkozó szakirodalmi közlemények a rendelkezésre álló mikrohullámú témakörben megjelent publikációknak csupán néhány százalékát teszik ki. Az eddigi eredmények tekintetében megállapítható, hogy a mikrohullám az iszapok esetében intenzív nedvességelvonást tesz lehetővé, továbbá az alkalmazásával egyes komponensek (pl. hasznosítható fémek) jó hatásfokkal kinyerhetőek, valamint az anaerob fermentációt megelőzően alkalmazva a biogáz produktum növelhetö.

Az egyes közleményekben szereplő kezelési körülményeket és eredményeket részletesen megvizsgálva azonban sok esetben egymásnak ellentmondó megállapítások szerepelnek. A mikrohullámú módszer alkalmazhatóságának megítélését megnehezíti, hogy a különböző típusú és geometriájú berendezésekkel, eltérő kezelési intenzitások alkalmazásával kapott eredmények eltérő mérési metodikájú és különböző számítási módszerekkel képzett mutatók felhasználásával kerültek értékelésre és bemutatásra. A rendelkezésre álló mikrohullámú előkezelési eredmények és tapasztalatok szinte kivétel nélkül kommunális eredetü, biológiai tisztítási fokozatból származó, csökkent szervesanyag tartalmú és alacsony szárazanyag tartalmú iszapokra vonatkoznak.

Mindezek figyelembevételével a kutatási munkám célkitűzéseként az élelmiszeripari eredetü, elsődleges szennyvíztisztítási technológiai lépcsőben keletkező iszapok 
mikrohullámú kezelésének vizsgálatát, a kezelések hatásának matematikai modellezését és optimálását fogalmaztam meg.

A mikrohullámú iszapkezelés vizsgálata során, az előzetes eredményeim alapján, a szakirodalmi közleményekben szereplő magnetron teljesítmény és kezelési idő, mint műveleti paraméterek mellett a közölt energia nagyságának és a fajlagos kezelési intenzitás mértékének, mint eljárás paraméterek a hatását vizsgáltam.

A kísérleti munkám célja volt továbbá, a mikrohullámú iszap-elökezelésnek az anaerob fermentáció folyamatára gyakorolt hatásainak elemzése is. Az előkezelések hatékonyságának vizsgálata és összehasonlíthatósága céljából a munkám során mezofil hőmérséklettartományú rothasztási próbák alkalmazásával vizsgáltam az anaerob fermentáció fajlagos biogáz-kihozatali mutatóit, az előkezelt iszapokból keletkező biogáz összetételét, illetve az anaerob lebontási folyamat dinamikáját. Mindezek ismeretében továbbá célom volt a mikrohullámú iszap előkezelések energiahasznosulási mutatóinak elemzése és a kezelések energetikai szempontú optimálása is. 


\section{IRODALMI ÁTTEKINTÉS}

\subsection{A mikrohullámú sugárzás és hőkeltési sajátosságai}

A mikrohullámú ipari- és háztartási készülékek alkalmazása egyre elterjedtebb, a mikrohullámú hőkeltés okozta számos előnyös tulajdonságai következtében. A fejezetben rövid összefoglalást adok a mikrohullámú sugárzásról, valamint annak speciális hőkeltési mechanizmusáról. Dolgozatom főbb tématerülete a mikrohullámú anyagkezelés, és ezen belül a mikrohullámú iszapkezelés, így a telekommunikációs, radartechnikai és méréstechnikai alkalmazások tárgyalásától eltekintettem.

\subsubsection{A mikrohullámú sugárzás fizikai alapjai}

A mikrohullámú (MW) sugárzás az elektromágneses (EM) spektrum azon tartománya, amelynek frekvenciája $300 \mathrm{MHz}$ és $300 \mathrm{GHz}$, illetve hullámhossza $10^{6}$ és $10^{9} \mathrm{~nm}$ között van. A teljes EM spektrumot tekintve a mikrohullámú tartomány az infravörös- és a rádiófrekvenciás sugárzás között található (Almássy, 1964).

A MW sugárzás tulajdonságai és hatásai hullámterjedési sajátosságaira vezethető vissza, mivel az, az EM sugárzás többi tartományához hasonlóan, oszcilláló elektromos-, és mágneses mezőkből álló hullámok sorozata. Az elektromágneses tér hullám- és korpuszkuláris tulajdonságokkal egyaránt rendelkezik, amelynek következtében az energia kvantumok formájában terjed.

Mivel a mikrohullámot a navigációs rendszerekben, a radar- és híradástechnikában széles körben alkalmazzák, a Nemzetközi Telekommunikációs Szövetség (ITU: International Telecommunication Union) az esetleges interferenciák elkerülése céljából az ipari-, tudományos- és orvosi- alkalmazások számára az ún ISM frekvenciasávokat jelölte ki, amelyek közül két frekvencia használata, a $915 \pm 13 \mathrm{MHz}$ és a $2450 \pm 50 \mathrm{MHz}$, engedélyezett ipari vagy háztartási felmelegítési feladatokban való alkalmazásra (Nelson, 2010). A mikrohullámú sugárzást hőkeltési célra 1937-től kezdték el használni, az első háztartási célra is használható mikrohullámú sütő 1947-ben jelent meg, majd 1975-től már a laboratóriumokban, kémiai reakciókban hőkeltési célra is alkalmazzák. (Remya et al., 2011). 
A frekvencia ( $\left.\left[\mathrm{Hz}-\mathrm{s}^{-1}\right]\right)$ és a hullámhossz $(\lambda[\mathrm{m}])$ között a hullám terjedési sebessége $\left(\mathrm{v}\left[\mathrm{ms}^{-1}\right]\right)$ teremt kapcsolatot.

$$
\lambda=\frac{v}{f} \quad[m]
$$

Ha az (1) általános összefüggést tekintjük, és az elektromágneses hullámok légüres térben való terjedési sebességét $\left(\mathrm{v}_{0}=3 \times 10^{8} \mathrm{~m} \mathrm{~s}^{-1}\right)$ vesszük számításba, az előzőekben meghatározott rögzített frekvenciákon a szabadtéri hullámhossz $\lambda_{2450 \mathrm{MHz}}=12,24 \mathrm{~cm}$ és $\lambda_{915}$ $\mathrm{MHz}=32,79 \mathrm{~cm}$ értékeknek adódnak.

Az elektromágneses tér egyes állapotjelzőinek kapcsolata a Maxwell-féle differenciálegyenlet rendszerrel írható le. Az elektromágneses tér állapota a hely- és időtől ( $\tau)$ függő elektromos térerősség $\left(\mathrm{E}\left[\mathrm{V} \mathrm{m}^{-1}\right]\right)$, a mágneses térerősség $\left(\mathrm{H}\left[\mathrm{A} \mathrm{m}^{-1}\right]\right)$, az elektromos eltolás $\left(\mathrm{D}\left[\mathrm{C} \mathrm{m}^{-2}\right]\right)$ és a mágneses indukció $\left(\mathrm{B}\left[\mathrm{N} \mathrm{s}(\mathrm{C} \mathrm{m})^{-1}\right]\right)$ vektorokkal írható le.

$\mathrm{Az}$ elektromágneses teret $\mathrm{az}$ áramsürüség $\left(\mathrm{J}\left[\mathrm{A} \mathrm{m}{ }^{-2}\right]\right)$ és a töltéssürüség $\left(\rho_{\mathrm{e}}\left[\mathrm{C} \mathrm{m}^{-3}\right]\right)$ hozza létre, és a közegek állapotjelzői közül a mágneses permeabilitás $\left(\mu\left[\mathrm{H} \mathrm{m}^{-1}\right]\right)$, az elektromos vezetőképesség $\left(\sigma\left[\mathrm{S} \mathrm{m}^{-1}\right]\right)$ és a permittivitás $(\varepsilon[-])$ a meghatározó. A Maxwellféle egyenletrendszer a (2)-(6) egyenletekkel adható meg (Pennock and Shepherd, 1998):

$$
\begin{aligned}
& \nabla \times H=\frac{\partial D}{\partial \tau}+J \\
& \nabla \times E=-\frac{\partial B}{\partial \tau}=-\frac{\partial \mu H}{\partial \tau} \\
& \nabla . J=\sigma E \\
& \nabla . D=\nabla . \varepsilon E=\rho_{e} \\
& \nabla . B=\nabla . \mu H=0
\end{aligned}
$$


A permittivitás $(\varepsilon)$ tehát megadható az elektromos térerősség és az elektromos eltolás (elektromos fluxus-sürüség) hányadosaként (Housecroft and Sharpe, 2005).

$$
\varepsilon=\frac{D}{E}\left[\frac{A s}{V m}\right]
$$

$\mathrm{Az}$ abszolút permittivitás értelmezhető a relatív permittivitás $\left(\varepsilon_{\mathrm{r}}[-]\right)$ bevezetésével, amely a vákuum permittivitásához $\left(\varepsilon_{0}=8,8542 \times 10^{-12}\left[\mathrm{As}(\mathrm{Vm})^{-1}\right]\right)$ viszonyított érték $(8)$.

$$
\varepsilon=\varepsilon_{0} \times \varepsilon_{\mathrm{r}}
$$

A relatív permittivitás továbbá a dielektromos állandó ( $\left.\varepsilon^{\prime}\right)$ és a dielektromos veszteségi tényező ( $\varepsilon ")$ felhasználásával a (9) általános formában is megadható (Komarov et al., 2005).

$$
\varepsilon_{\mathrm{r}}=\varepsilon^{\prime}-\mathbf{j} \varepsilon^{\prime \prime}
$$

A kifejezés komplex szám, amely megmutatja, hogy a külső tér polarizáló hatását a molekuláris súrlódás csillapítja. A komplex kifejezés valós tagja, a dielektromos állandó $\left(\varepsilon^{\prime}\right)$, a kezelt anyagnak az elektromos tér energiájára vonatkozó tároló képességét jellemzi. A képzetes rész, a dielektromos veszteségi tényező ( $\varepsilon^{\prime \prime), ~ e ́ r t e ́ k e ~ a z ~ a n y a g b a n ~ t o ̈ r t e ́ n o ̋ ~}$ elnyelődés (abszorpció) következtében létrejövő hőkeltés mértékével arányos, amely az elektromos tér szempontjából veszteségként jelentkezik (Beke, 1997).

A gyakorlati tapasztalatok szerint a $10^{-2}$-nál kisebb dielektromos veszteségi tényezővel rendelkező anyagoknál csak nagy elektromos térerősség esetén érhető el számottevő hőmérsékletemelkedés, jelentős felmelegedést csak az 5-nél nagyobb dielektromos veszteségi tényezővel rendelkező anyagoknál tapasztalunk.

Az mikrohullámú sugárzással szembeni viselkedésük alapján az anyagok három csoportba oszthatóak:

- elnyelők (abszorbeálók, dielektrikumok): pl. víz

- áteresztők (transzparens anyagok): pl.: teflon

- visszaverők (reflektáló anyagok): pl.: fémek 


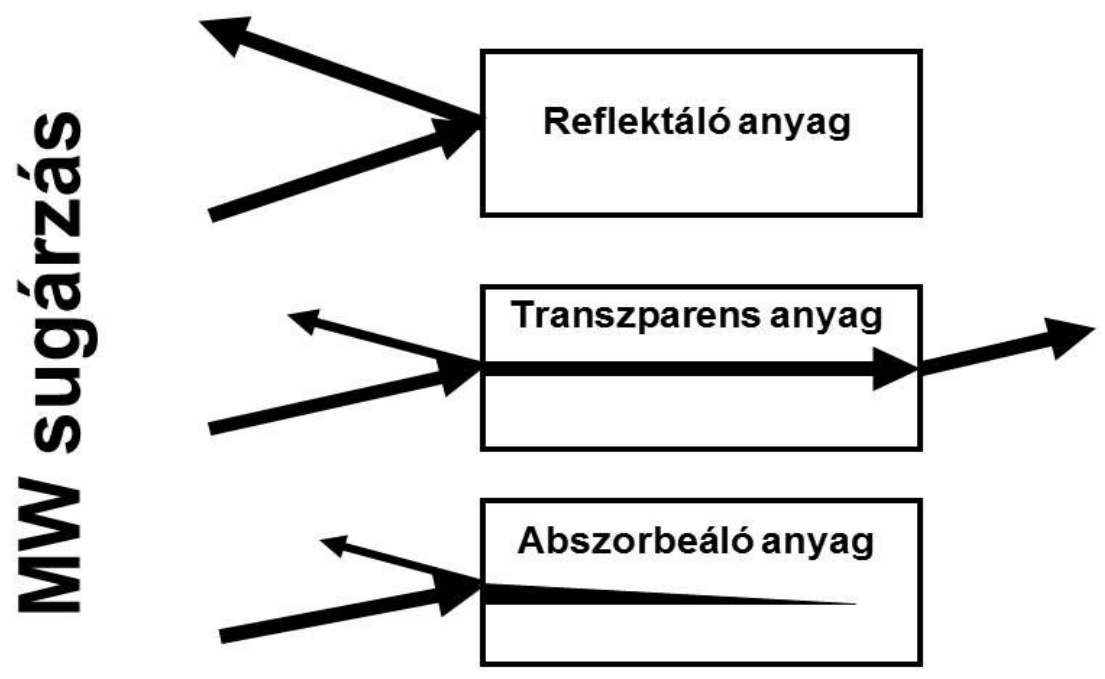

1. ábra. Anyagok viselkedése mikrohullámú (MW) sugárzás hatására (Remya and Lin, 2011 alapján)

Mivel az anyagok sugárzást elnyelö-, illetve visszaverő képessége elsősorban a dielektromos tulajdonságuk által meghatározott, ezért az áteresztő anyagok alacsony-, az abszorbeálók magas dielektromos veszteségi tényezővel jellemezhetőek. A mikrohullámú sugárzás, az azt elnyelő (veszteséges) közegben az ún. dielektrikumokban, a szabadtéritől eltérő hullámhosszakon terjed. Egyfázisú rendszerben, illetve dielektromos szempontból homogén anyagokban a dielektromos állandó permittivitás $(\varepsilon)$ és a sugárzás vákuumban való terjedési hullámhossza $\left(\lambda_{0}\right)$ ismeretében a terjedési hullámhossz $(\lambda)$ a (10) összefüggéssel adható meg (Pozar, 1998).

$$
\lambda=\frac{\lambda_{0}}{\varepsilon^{0,5}} \quad[m]
$$

Gyakorlati szempontok alapján, a klasszikus hullámterjedési tulajdonságokon történő csoportosításon túl, egy negyedik csoportot az ún. kevert abszorbereket is megkülönböztetnek. Ebbe a csoportba gyakorlatilag a különféle kompozitok és az eltérő dielektromos tulajdonságú anyagokból álló, többfázisú rendszerek tartoznak. Az alacsony dielektromos veszteségü komponensen a mikrohullámú sugárzás kis elnyelődés mellett, vagy gyakorlatilag csillapítás nélkül, keresztülhatol, míg a magas veszteségü komponens(ek) abszorbeálják a sugárzott energiát, vagyis létrejön az ún. „szelektív melegítés” (Leadbeater, 2011). A mikrohullámú melegítés specifikuma éppen ez, hiszen 
sem konvektív, sem konduktív, sem radiációs hőközlés esetében a szelektív felmelegedés nem tapasztalható. A különböző dielektromos tulajdonságú komponenseket tartalmazó rendszerek esetében fellépő szelektív felemelegedést használják ki az úgynevezett mikrohullámú hibrid hevítési (MHH) eljárásokban is ahol az alacsony veszteségi tényezőjü felmelegítendő anyaghoz valamilyen magas mikrohullámú energia abszorpcióra képes magas dielektromos veszteségi tényezővel rendelkező - szilárd részecskét, például szilícium-karbidot adagolnak. A mikrohullámú sugárzás a transzparens anyagon áthatol, az abszorber gyorsan és magas hőmérsékletre melegedve döntően radiációval adja át a hőt az őt körülvevő fázisnak. Sok esetben a transzparens anyag magasabb hőmérsékleten már képes abszorbeálni a mikrohullámú energiát, így a felmelegedési sebesség ugrásszerüen tovább növekszik (Clark et al., 2000).

Diszperz fázist tartalmazó rendszerek átlagos effektív permittivitásának $\left(\varepsilon_{\mathrm{eff}}\right)$ számítására a folytonos fázis permittivitásának $\left(\varepsilon_{1}\right)$ és a diszperz fázist alkotó komponens térfogati koncentrációjának $\left(c_{2}\right)$ és permittivitásánák $\left(\varepsilon_{2}\right)$ ismeretében a (11) Garnett-féle összefüggés használható (Greffe et al., 1992).

$$
\varepsilon_{\text {eff }}=\varepsilon_{1} \frac{2 \varepsilon_{1}+\varepsilon_{2}+2 c_{2}\left(\varepsilon_{2}-\varepsilon_{1}\right)}{2 \varepsilon_{1}+\varepsilon_{2}-c_{2}\left(\varepsilon_{2}-\varepsilon_{1}\right)}
$$

Az összefüggés alkalmazásának feltétele, hogy a diszperz fázis térfogati koncentrációja $20 \%$, vagy ennél kisebb; illetve a folytonos fázis permittivitása a diszperz fázisét ne haladja meg. Egy szélesebb körben, mintegy 50\%-os koncentráció értékig alkalmazható a kétfázisú rendszerek permittivitásának becslésére a (12) számú Kamyoshi öszefüggés (Kremer and Schönhals, 2003).

$$
\varepsilon_{\text {eff }}=\frac{2 \varepsilon_{\mathrm{I}} \varepsilon_{\mathrm{II}}}{\varepsilon_{\mathrm{I}}+\varepsilon_{\mathrm{II}}}
$$

ahol,

$$
\begin{gathered}
\varepsilon_{\mathrm{I}}=\varepsilon_{1}\left[\left(1+3 c_{2}\right) /\left(\frac{2 \varepsilon_{1}+\varepsilon_{2}}{\varepsilon_{2}-\varepsilon_{1}}-c_{2}-0.525\left(\frac{3 \varepsilon_{2}-3 \varepsilon_{1}}{3 \varepsilon_{2}+4 \varepsilon_{1}}\right) c_{2}^{10 / 3}\right)\right] \\
\varepsilon_{\mathrm{II}}=\varepsilon_{2}\left[\left(1+3\left(1-c_{2}\right) /\left(\frac{2 \varepsilon_{2}+\varepsilon_{1}}{\varepsilon_{1}-\varepsilon_{2}}-\left(1-c_{2}\right)-0.525\left(\frac{3 \varepsilon_{1}-3 \varepsilon_{2}}{3 \varepsilon_{1}+4 \varepsilon_{2}}\right)\left(1-c_{2}\right)^{10 / 3}\right)\right]\right.
\end{gathered}
$$

Az egyes fázisok jelölései a (11) egyenletben használtakkal megegyeznek. 


\subsubsection{A mikrohullámú hőkeltés alapjai}

A mikrohullámú sugárzás hatására az anyagban történő hőfejlődés, az anyagi tulajdonságoktól függően, alapvetően két mechanizmus, az ionos polarizáció és a dipólusos rotáció útján mehet végbe. Az ionos polarizáció jelensége olyan oldatok esetében számottevő, ahol oldott állapotú, elmozdulásra képes ionok vannak jelen. Az időben gyorsan változó elektromágneses térben a hidratált, vagy szolvatált ionok az erőtér pólusainak változása miatt folyamatosan változó irányú mozgásban vannak. Az ionok vándorlása és a folyamatos ütközések következtében a részecskék kinetikai energiája hőenergiává alakul át (Metaxas and Meredith; 1993).

A poláris molekulák az elektromágneses erőtér nélkül is dipólus-momentummal, ún. permanens dipólus-momentummal, rendelkeznek. A poláros anyagok dipólusai a szinuszosan változó nagyfrekvenciás térnek (amely az egyik fél-periódusban pozitív a másik fél-periódusban negatív) megfelelően állnak be, azaz forognak, és forgásuk során a molekulák közötti súrlódás következtében, továbbá egyes esetekben a kötések felbomlásával, az elektromos energia először mozgási-, majd hőenergiává alakul. Az apoláris anyagok a mikrohullámú energiát nem képesek elnyelni, vagyis szigetelőként viselkednek. Azonban az elektromágneses sugárzás a molekulák elektronjainak átrendeződését okozhatja, ún. indukált dipólusokat hozhat létre, amelyek elősegítik a sugárzási energia abszorpcióját (Jacob et al., 1995).

A molekulák dielektromos térben történő relaxációjának (visszarendeződésének) ideális esetben történő leírására a Debye egyenlet használható, amelyből az anyag $\varepsilon_{\infty}$ végtelen nagy frekvenciához tartozó dielektromos állandója ismeretében a relaxációs idő $(\tau)$ a (15) egyenlettel adható meg (Tang et al., 2002).

$$
\tau=\frac{\varepsilon^{\prime \prime}}{2 \cdot \pi \cdot f}\left(\mathcal{E}^{\prime}-\varepsilon_{\propto}\right)
$$

Az általános definíciója szerint a relaxációs idő az az idő, amely alatt az elektromágneses tér megszűnése után az orientációs polarizáció 1/e-ed részére csökken. Általánosságban a nagyobb méretű molekulák nagyobb relaxációs idővel jellemezhetőek. A mikrohullámú sugárzás intenzitása az anyagba hatolva, annak dielektromos tulajdonságaitól függően, csillapodik. Az elektromos tér erősségének az anyagba történő belépésnél tapasztalható $\mathrm{E}_{0}$ értékről 1 hosszon való exponenciális csökkenése, a Lambert-Beer 
törvénynek megfelelően, a dielektromos jellemzők figyelembevételével, a összefüggéssel leírható.

$$
E=E_{0} \exp \left[-\left(\frac{2 \pi}{\lambda} \frac{\varepsilon^{\prime \prime}}{\sqrt{\varepsilon^{\prime}}}\right)\right]
$$

A Lambert-Beer törvénnyel az anyagon belüli hőterjedés, valamint az elektromágneses sugárzás penetrációja legtöbb esetben kielégítő pontossággal leírható, és a Maxwell egyenletektől eltérően, nem szükséges az elektromágneses tér erősségének anyagon belüli meghatározása, amely méréstechnikai szempontból sok esetben nehezen kivitelezhető (Curet et al., 2008). Ha azonban a kezelt anyag rétegvastagsága lényegesen kisebb, mint az adott frekvencián a sugárzás behatolási mélysége, a reflexiós jelenségek hatásának figyelembevételére az egyszerübb Lambert törvény már nem alkalmas (Yang and Gunsekaran, 2004; Bhattacharya and Basak, 2006). A csillapodás, frekvenciától és az anyagi tulajdonságoktól függő mértékének jellemzésére, elsősorban a kezelő-berendezések tervezése és a sugárzásnak az egyes közegekben való terjedésének vizsgálata során a csillapítási tényező $(\alpha)$ használatos (Ayappa et al., 1991).

$$
\alpha=\frac{2 \pi}{\lambda}\left[\frac{\varepsilon^{\prime}}{2}\left(\sqrt{1+\left(\frac{\varepsilon^{\prime \prime}}{\varepsilon^{\prime}}\right)^{2}}-1\right)\right]^{0,5}
$$

A reális dielektrikumok a vezetőképességük következtében saját disszipációval is rendelkeznek. Az anyagban az eredő áramsűrűség vektor és a térerősség vektor egymással 90- $\delta$ szöget zár be. A tan $\delta$, a $\delta$ veszteségszögből képzett tag, amely a mikrohullámnak a közegben való elnyelődését és az anyagot való felmelegítő képességére egyaránt jellemzi (Kumar et al., 2001). A mikrohullámú tér magas körfrekvenciája (ळ) miatt a saját vezetőképesség lényegesen alacsonyabb, mint a $\varpi \varepsilon$ ” szorzat, ezért a dielektromos állandó és a dielektromos veszteségi tényező ismeretében a tan $\delta$ a (18) képlettel számítható (Metaxas and Meredith; 1993).

$$
\tan \delta=\frac{\varepsilon^{\prime \prime}}{\varepsilon^{\prime}}
$$

A mikrohullámú sugárzás formájában az anyagba hatoló energia hőenergiává való transzformációjának mértékével összefüggő dielektromos veszteség - $\varepsilon$ ”, illetve a felmelegedés mértékét és sebességét egyaránt és egy paraméterben jelző veszteség tangens, 
tanঠ, az anyagot alkotó molekulák geometriájától, kötéstípusaitól és azok elrendezésétől, valamint a hőmérséklettől és a sürüségtől, de biológiai anyagok esetében például a víztartalomtól, és azon belül a víz kötési módjától is függ (Nelson, 2010).

A dielektromos anyagi jellemzők a frekvencia, illetve a hőmérséklet függvényében is változnak. A legtöbb folyékony halmazállapotú, dielektromos szempontból „,veszteséges” anyagnál a dielektromos veszteségi tényező értékét alacsonyabb frekvenciatartományban elsősorban az ionos vezetés befolyásolja, míg magasabb frekvenciatartományban az ionos vezetés és a dipólus rotáció egyaránt meghatározó (Tang et al., 2002). Heterogén rendszerekben, alacsony frekvenciájú sugárzás esetében a Maxwell-Wagner polarizációs effektus is hozzájárul a dielektromos veszteségi tényező értékének növekedéséhez, amely a komponensek érintkezési felületén bekövetkező töltéssűrűség változásra vezethető vissza (Holtze et al., 2006).

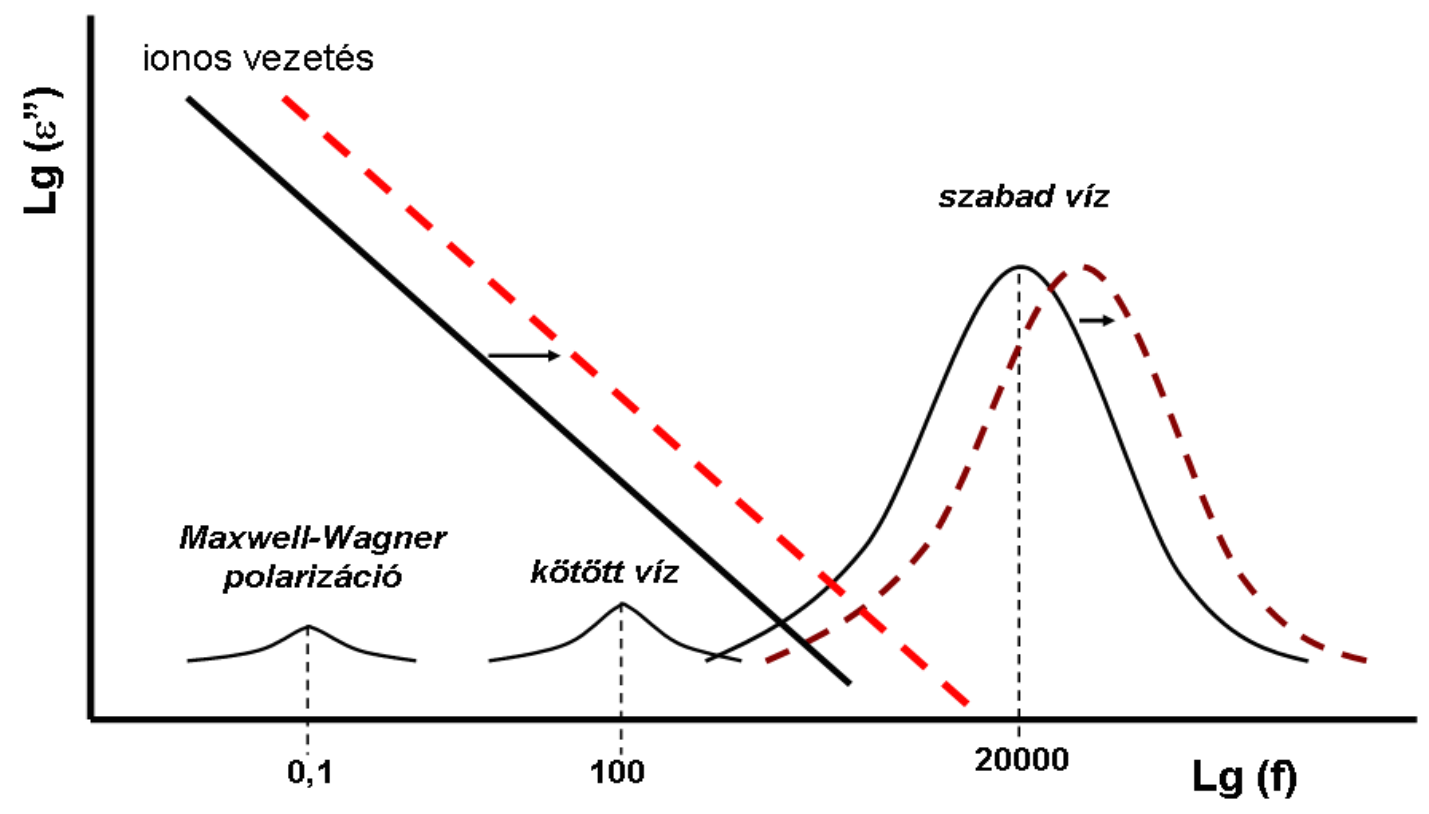

2. ábra: A dielektromos veszteségi tényező ( $\varepsilon ")$ értékét meghatározó mechanizmusok különböző frekvencia tartományokban (Tang et al., 2002 alapján)

Tiszta víz esetében a dielektromos veszteségi tényező a maximális értékét a Debye egyenlettel (19) meghatározható t relaxációs időtől függő kritikus frekvencián $\left(f_{\text {krit }}\right)$ veszi fel.

$$
\mathbf{f}_{\text {krit }}=\frac{1}{2 \pi \tau}
$$


Vizet tartalmazó összetett rendszerekben a poláris vízmolekulák a poláris tulajdonságú összetevők felületén egy- vagy több molekula vastagságnyi rétegben, kötött víz formájában, helyezkednek el. A kötött víz relaxációs ideje nagyobb, mint a szabad vízmolekuláké, ezért az attól fordított arányban függő kritikus frekvenciaértékek az alacsonyabb tartományba tolódnak el (Komarov et al., 2005).

A hőmérsékletnek a dielektromos jellemzőkre gyakorolt hatása a relaxációs idő változásával áll összefüggésben. A hőmérséklet növekedésével a folyadékok viszkozitása csökken, ami a molekulák elmozdulással szembeni ellenállásának csökkenésével a relaxációs idő értékét is csökkenti. A vezetőképesség a hőmérséklet növekedés hatására növekszik, amelynek oka egyrészt az ionok mobilitásának a hőmérséklet növelés hatására bekövetkező fokozódása, másrészt a hőmérsékletnövelés okozta viszkozitás csökkenés (Wang et al., 2003). Mindezek értelmében a kritikus frekvenciaérték a hőmérséklet emelkedésével növekszik és a frekvencianövelés a veszteségi tényező értékét csökkenti. Ionokat tartalmazó oldatok esetében, egy rögzített frekvenciájú sugárzást alkalmazva, a hőmérséklet növelése a dielektromos veszteségi tényező értékét növeli, poláris molekulák alkotta rendszerekben $0{ }^{\circ} \mathrm{C}$ feletti tartományban pedig csökkenti (de los Santos et al., 2003).

A dielektromos veszteségi tényezőnek a hőmérséklet hatására bekövetkező csökkenése a kezelések energetikai mutatóit rontja, de már régóta ismert, hogy például egyes élelmiszerek esetében éppen ez a csökkenés csökkenti a túlhevülés mértékét. A kisebb energiaabszorpció kisebb mértékű hőfejlődés mellett szilárd testekben a vezetéses hőtranszport révén már lehetővé teszi, hogy a hőmérsékletmező inhomogenitása csökkenjen (Bengtsson and Risman, 1971). A frekvencia növelésének a dielektromos állandóra, egy meghatározott értékig nincs számottevő hatása, ebben az alacsony- frekvenciatartományban a dielektromos állandó a frekvenciától független (statikus). A frekvencia további növelése a dielektromos állandó csökkenését és a dielektromos veszteségi tényező növekedését okozza, a vízmolekuláknak az elektromágneses térben létrejövő diszperziós kölcsönhatásainak következtében (diszperziós terület). Egy kritikus frekvenciát elérve a dielektromos állandó értéke eléri minimumát, állandósul. A dielektromos jellemzők szempontjából meghatározó diszperziós hatások víz esetében szük-, többkomponensü vizet tartalmazó - rendszerekben szélesebb frekvenciatartományban jellemzőek, mivel az utóbbi esetben az ionos vezetés is hatást gyakorol a dielektromos tényező, és a dielektromos veszteségi tényező értékére is. (Beneduci A., 2008). 


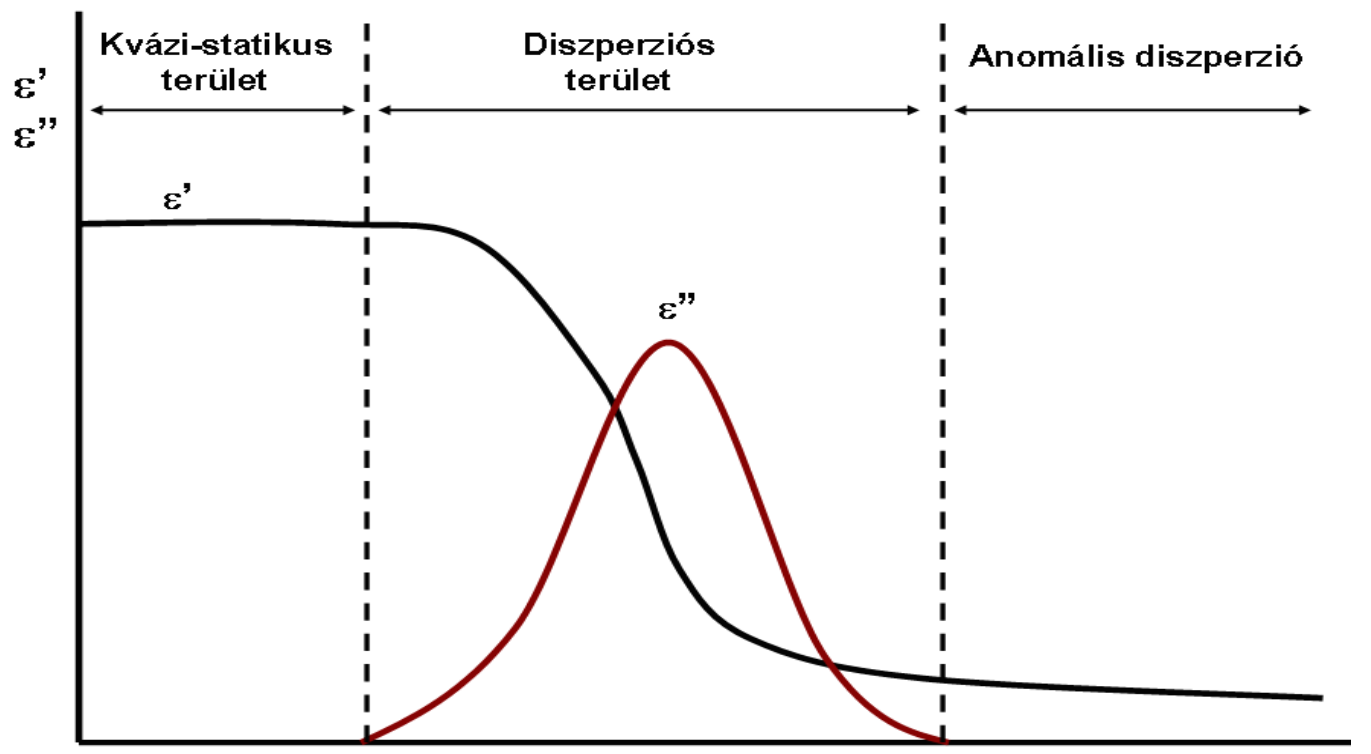

$\operatorname{Lg}(\mathbf{f})$

3. ábra. A dielektromos állandó és veszteségi tényező változása a frekvencia függvényében (Beneduci A., 2008 alapján)

A mikrohullámú szárítási folyamatok során a dielektromos állandó és a dielektromos veszteségi tényező egyaránt csökken. Ennek egyik természetes oka az abszolút nedvességtartalom csökkenése, másrészt, a szabad víztartalom csökkenése, amely már nemcsak a dipólusos mechanizmusok hatásfokát csökkenti, hanem az ionos vezetési jelenségekre is negatív hatással van. A szárítás esetében a nedvességtartalom egy kritikus érték alá csökkenése esetén, kapillár-porózus anyagok esetében, a pórusok egy részét már levegő tölti ki, amely az anyag átlagos dielektromos állandójának és a dielektromos veszteségi tényezőnek az értékét egyaránt csökkenti (Nelson et al., 1994).

Az anyagok különböző dielektromos vesztesége miatti eltérő felmelegedést használják ki például a szerves kémiai szintéziseknél is. Kétfázisú - kloroform/víz - rendszerben a magas hőmérsékleten lejátszódó, poláris tulajdonságú vegyületekből kiinduló szintézis reakcióközegeként a vizes fázist használták, míg az apoláris jellegü termék a szerves oldószerben oldódott. Mivel a kloroform dielektromos veszteségi tényezője alacsonyabb, mint a vízé, így a terméket tartalmazó fázis csak enyhén melegedett fel, amely megakadályozta, hogy a termék hőbomlást szenvedjen (Raner et al., 1995).

A dielektromos szempontból veszteséges rendszerek esetében, az elektromos térerő, és ezáltal a hatásos mikrohullámú teljesítmény értéke is exponenciálisan csökken az anyag belseje felé haladva. A felülettől vett x [m] távolságban, a felületet érő mikrohullámú 
sugárzás teljesítményének $\left(\mathrm{P}_{0}\right)$ és a csillapítási tényezőnek $(\alpha)$ az ismeretében a hatásos teljesítmény (P) a (20) összefüggéssel számítható (Komarov, 2012).

$$
\mathbf{P}=\mathbf{P}_{0} \mathbf{e}^{-2 \alpha z}[\mathbf{W}]
$$

A mikrohullámú melegítés során a csillapítási tényezőn kívül az annál szemléletesebb eredményt adó behatolási mélység számítását végzik. A behatolási (penetrációs) mélységet $\left(\mathrm{d}_{\mathrm{p}}\right)$ legtöbbször annak a távolságnak definiálják, amelyen belül a felületet érö mikrohullámú térerősség a behatolási felületen tapasztalható érték 1/e-ed részére csökken.

A közeg dielektromos állandója ( $\left.\varepsilon^{\prime}\right)$, dielektromos veszteségi tényezője ( $\varepsilon^{\prime \prime), ~ a ~ f e ́ n y ~}$ vákuumban való terjedési sebesség $\left(\mathrm{v}_{0}\right)$ és a frekvencia értékének függvényében a penetrációs mélység a (21) összefüggéssel számítható (Chandrasekaran et al., 2012).

$$
d_{p}=\frac{v_{0}}{2 \sqrt{2} \pi f\left\{\varepsilon^{\prime}\left[\sqrt{1+(\tan \delta)^{2}}-1\right]\right\}^{0,5}}[m]
$$

A fenti összefüggés alapján is látható, hogy azonos anyag esetében a magas frekvencia kisebb, az alacsonyabb frekvencia pedig nagyobb mélységü penetrációt tesz lehetővé, vagyis magas frekvenciájú kezeléssel felületi, alacsonyabb frekvencián inkább térfogati felmelegedés tapasztalható. A dielektromos tényező, illetve a tan $\delta$ értéke fordított arányosságban áll a penetrációs mélységgel.

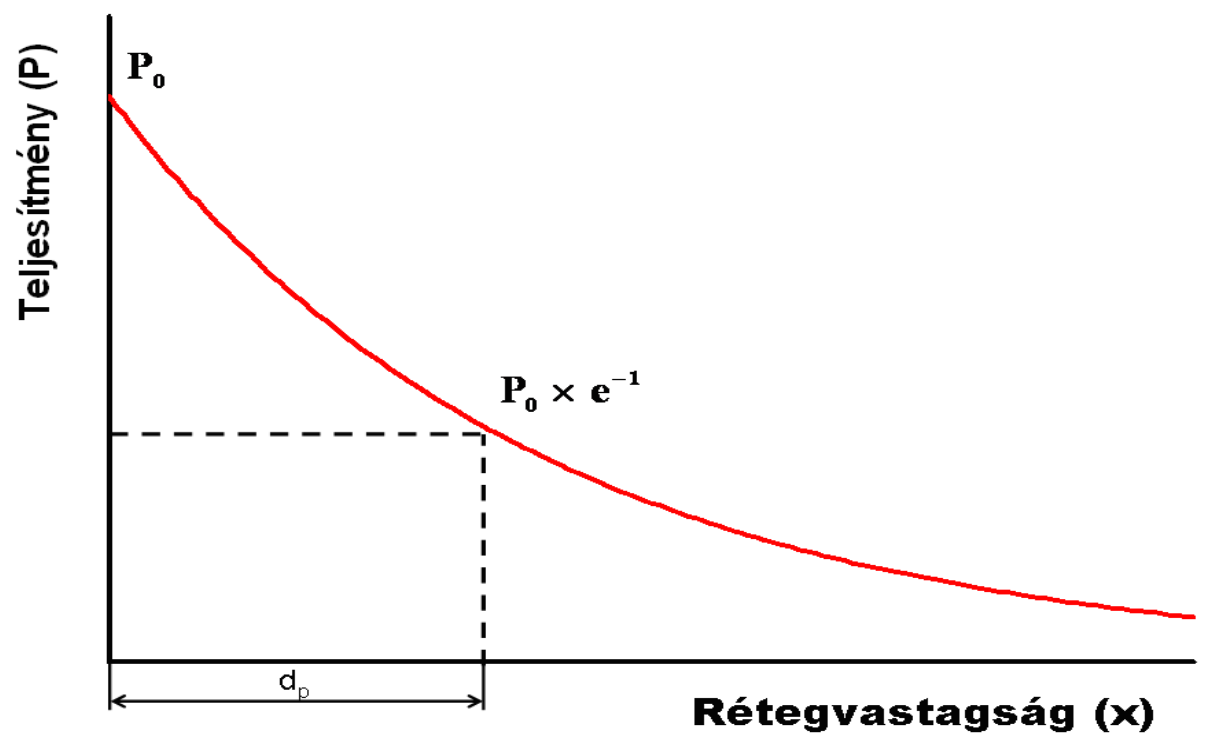

4. ábra: A penetrációs mélység $\left(\mathrm{d}_{\mathrm{p}}\right)$ értelmezése (Komarov et al., 2005 alapján) 
Az általános megállapítás, miszerint a mikrohullámú energiaközléssel az anyag belülről, egyenletesen melegíthető fel, csak a penetrációs mélység határán belül tekinthető igaznak. Ha az alkalmazott mikrohullámú sugárzás hullámhossza a kezelt anyag egyik lineáris méretével megegyezik, állóhullám alakul ki, amely elősegíti az ún. „hot-spot”-ok kialakulását és nagymértékben rontja a hőmérsékletmező homogenitását. A „hot-spot” kialakulását, illetve a hőmérséklet homogenitás időbeni instabilitását elősegíti az is, hogy az elektromágneses tulajdonságok és a hőtani paraméterek egyaránt hőmérséklettől függőek, azonban a hőmérséklettel nem lineárisan és nem azonos arányban változnak (Reimbert et al., 1996). Az állóhullámok kialakulása a frekvencia csökkentésével is lehetséges; az alacsonyabb frekvencián a dielektromos állandó és a veszteségszög is növekszik. Az elektromágneses sugárzást tekintve tehát a hatásfok javul, azonban a teljesítmény-veszteségből eredő hőmennyiség értéke ezzel ellentétesen változik, vagyis az elektromágneses sugárzás hőenergiává való transzformációja magasabb frekvencián kedvezőbb.

Az anyagban elnyelődött (abszorbeált, vagy disszipálódott) teljesítményt $\left(\mathrm{P}_{\mathrm{d}}\right)-$ mivel a mikrohullámú hevítés esetében sokszor annak térfogati felmelegítő tulajdonságát emelik ki - legtöbbször térfogatra vonatkoztatva adják meg, mennyisége a (22) összefüggéssel számítható a frekvencia (f), a kezelt anyagban kialakuló elektromos térerő (E) és az anyag relatív (vákuumra vonatkoztatott) dielektromos tényezője $\left(\varepsilon_{\mathrm{r}}\right)$ ismeretében (Metaxas and Meredith; 1993).

$$
P_{d}=2 \pi f \varepsilon_{0} \varepsilon_{r} \tan \delta|E|^{2} \quad\left[\frac{W}{m^{3}}\right]
$$

Mint ahogyan a fenti összefüggésben is látható, az elnyelődött teljesítmény nagyságát a frekvenciától is függő anyagi jellemzők, a dielektromos tényező, illetve a veszteségi tényező határozza meg, a hagyományos hőkeltési mechanizmusokban meghatározó fajhő, vagy a hővezetési tényező, illetve egyéb anyagi tulajdonságok közül például, a sürüség nem szerepel. Ezek alapján tehát a felmelegítési folyamatok mennyiségi jellemzése tisztán villamos paraméterekre is visszavezethető lenne, amely a folyamatszabályozás területén új lehetőségeket teremtene. Azonban nem hagyható figyelmen kívül az a tény sem, hogy a dielektromos paramétereket a frekvencián túl a mikrohullámot abszorbeáló médium hőmérséklete is befolyásolja (Göllei et al., 2010). 
A dielektromos szempontból veszteséges anyagok esetében az anyagban elnyelődő mikrohullámú teljesítmény legnagyobb része az anyag felmelegítésére fordítódik. Az anyag dielektromos, fizikai és hőtani jellemzőit, mint a sürüség $\left(\rho\left[\mathrm{kgm}^{-3}\right]\right)$ és a fajhő $\left(\mathrm{c}_{\mathrm{p}}[\mathrm{kJ}(\mathrm{kg}\right.$ $\left.\mathrm{K})^{-1}\right]$ ), figyelembe véve, a felmelegítés során a hőmérsékletemelkedési sebesség $\left(\frac{\Delta T}{\Delta \tau}\right)$ megadható a következő formában (Komarov et al., 2005):

$$
\frac{\Delta T}{\Delta \tau}=\frac{2 \pi f \varepsilon_{0} \varepsilon_{r} \tan \delta|E|^{2}}{\rho c_{p}} \quad\left[\frac{K}{s}\right]
$$

A mikrohullámú sugárzást széleskörüen használják elsősorban olyan alkalmazásokban, ahol gyors felmelegítésre van szükség. A hagyományos kondukciós és konvekciós hőtranszporton alapuló hőkeltési eljárásokban a hőenergia a külső érintkezési felület felől a belső rétegek felé halad. Ezzel szemben a mikrohullámú kezelések esetében, a behatolási mélységen belül, a hőfejlődés az anyagon belül történik (Szabó et al., 1998a).

Poláris tulajdonságú komponenseket tartalmazó oldatok esetében, már az alkalmazott mikrohullámú kutatások korai időszakában megfigyelték az ún. túlhevülési jelenséget is. Ebben az esetben a mikrohullámú melegítéskor az oldat fötömegében mérhető forráspont magasabb, mint a normál forrásponti hőmérséklet. Ennek magyarázata szintén a mikrohullám térfogati felmelegítő hatásában rejlik, mivel a penetrációs mélységen belül a hagyományos felmelegítéssel szemben ellentétes irányú, a folyadékfelszín felé irányuló, hőmérsékletgradiens tapasztalható. Mivel a forrási gócpontok nagyobb valószínüséggel a folyadék felszínén alakulnak ki, illetve figyelembe véve a felszínen kialakuló buborékokat alkotó - a fázisátmenet során képződő - pára hőtranszportot lassító hatását, a mikrohullámú energiaközléssel a rendszerbe bevitt energia a párolgó felület nagyobb ellenállása miatt a folyadék főtömegében magasabb hőmérsékletet idéz elő (Baghurst and Whittaker, 1997).

Meg kell azonban azt a tényt is jegyezni, hogy a hagyományos hőközlés esetében a fütött felületen képződött, majd az egész folyadéktérfogaton át a felszín felé mozgó buborékok keverő hatása a mikrohullámú kezelés esetében kisebb mértékü, amely szintén a túlhevülés kialakulását segíti elő. 


\subsection{A mikrohullámú sugárzás alkalmazása és hatásai}

Az alfejezetben a mikrohullámú energiaközlés néhány jellemző felhasználási területéről származó eredményt foglaltam össze, külön tárgyalva a mikrohullámú sugárzás specifikus hatásait a biológiai rendszerekre. A mikrohullámú iszap kezelések eddigi eredményeit részletesebben, a következő alfejezetben tárgyalom.

\subsubsection{A mikrohullám alkalmazási területei}

A mikrohullámú sugárzás sajátságos, belső hőkeltési mechanizmusa nem csupán laboratóriumi-, hanem ipari körülmények között is alkalmazható. Már az 1970-as évek elején először félüzemi méretű kísérletekben, majd a '80-as évektől Parallam ${ }^{\circledR}$ néven McMillan és Bloedel által kifejlesztett és szabadalmaztatott eljárásban, ipari méretekben is használták a mikrohullámú felmelegítéssel végzett polimer-fa laminálási technológiát. A mikrohullámú sugárzást alkalmazó technológiának a hagyományos felmelegítéssel végzett bevonáshoz és színezéshez képest a legfontosabb müveleti előnye a gyorsasága, a minőségi paramétereket tekintve pedig a felület és a belső részek közötti - penetrációs mélységen belüli - színezetbeni eltérés elkerülhetősége volt (Churchland, 1995).

Az üveggyártásban, az üveg szilárdságának növelése céljából végzett felületi ioncserén alapuló gyártási eljárás során, összehasonlítási célzattal vizsgálták a mikrohullámú (MW) és a hagyományos hőkeltési eljárás hatékonyságát. Megállapították, hogy azonos hőmérsékletprofil alkalmazása esetén az ioncsere sebessége magasabb és az ionok diffúziójában résztvevő réteg vastagsága nagyobb volt a $\mathrm{MW}$ eljárás esetében. Az üveggyártás során továbbá igazolták, hogy az anyag amorf formájában a dielektromos veszteségi tényező magasabb, mint kristályos állapotban. A kristályosodási magok megjelenésével ugrásszerüen csökkenő veszteségi tényező következtében az anyag a mikrohullám számára transzparenssé válik, az energia-abszorpció csökken, vagyis a hőmérsékletfelfutási görbén töréspont mutatkozik. A hagyományos hőkezeléstől eltérően tehát a MW eljárás esetében egy hőmérséklet-önszabályozó mechanizmus tapasztalható, amely az anyag túlhevülését külső beavatkozás nélkül akadályozza meg (Clark et al., 2000).

Az elektromágneses sugárzáson alapuló hőkeltési eljárásokat a környezetvédelemben is évtizedek óta hasznosítják. Az olajhomokból szelektív melegítéssel történő bitumenkinyerést már az 1970-es években vizsgálták (Kawala and Atamanczuk, 1998). A talajból történő kilevegőztetési eljárások, a talajok in-situ remediációja során, az illékony 
vegyületek, mint például a policiklikus szénhidrogének (PAH) és a poliklórozott bifenilek (PCB) eltávolítása, vagy a nehézfémek talajból történő kinyerése során a mikrohulámú módszerek szintén előtérbe kerültek (Jones et al., 2002).

A poláris tulajdonságú vegyületek esetében a mikrohullámú sugárzás önmagában alkalmas a hőkeltéssel járó kármentesítésre, apoláris vegyületek eltávolításakor a hőfejlődés elöidézésére mágneses tulajdonságú nanorészecskéket adagoltak (Holzwarth et al., 1998). A kigőzölési eljárásoknál azonban a talajnedvesség is intenzíven elpárolog, így a nedvességtartalom csökkenése a talaj mikrohullámú energiát abszorbeáló képességét csökkenti, így a felmelegedés mértéke is folyamatosan csökken. Mivel azonban a talajszerkezet és a talajerő megőrzése szempontjából a humuszanyagok megőrzése előnyös, a talajszennyező poláros vegyületek szelektív, a többi talajalkotótól nagyobb mértékü felmelegedése az eljárás egyik legfontosabb előnye.

$\mathrm{Az}$ elektronikai hulladékok esetében a manapság egyre magasabb árú színes- és nemesfémek kinyerése során is már több mint két évtizede szabadalmaztatott a kétlépcsős mikrohullámú eljárás, amelynek az első lépesében a mủanyag részek leolvasztása és az alacsonyabb olvadáspontú fémek (ón, alumínium) eltávolítása, a második lépésben egyes szennyező komponensek megszilárdítása és a magasabb olvadáspontú fémek elválasztása történik (Wicks and Schulcz, 1998). A szabadalmaztatott eljárást később továbbfejlesztették kórházi veszélyes hulladékok és gumiabroncsok ártalmatlanítására, illetve újrahasznosítására.

A többrétegü csomagolóanyagok megjelenésével azok lehetséges újrahasznosítási eljárásainak fejlesztése is megkezdődött. A Ludlow-Palafox és Chase (2001) által kifejlesztett eljárásban a csomagolási hulladékot oxigénmentes körülmények között, a nagyobb mértékü energiaabszorpció céljából szénágyban, mikrohullámmal hevítik, így a pirolízis során az alumínium nagy tisztaságban nyerhető vissza.

A gumiabroncsok újrahasznosítása során is vizsgálták a mikrohullámú hőkeltés alkalmazhatóságát. Amennyiben a poláris tulajdonságú adalékot, mint például kénvegyületeket, használtak a gumigyártási technológiában a vulkanizáláshoz, a mikrohullámú sugárzás jó hatásfokkal alkalmazható a devulkanizálás során a C-C kötések bontására, további depolimerizációs folyamatok lejátszódása nélkül. Ebben az esetben az 
eljárás rentábilissá tehető a hagyományos őrléssel történő előkészítési módszerhez képest (Adhikari et al., 2000).

A bányászati és kohászati technológiákban az aprítás és őrlés előkészítő műveleteként is régóta vizsgálják a mikrohullámú sugárzás hatásfokát. A termikus előkészítési műveletek esetében a hőközlést a kristályok rácsszerkezetének gyengítésére használják, amely következtében az aprítási müvelet energiaszükséglete csökkenthető. A kőzetet alkotó ásványok eltérő dielektromos tulajdonságából következően azok mikrohullámú energiaabszorpciója is különböző, továbbá az összetételtől függően a dielektromos jellemzők hőmérsékletfüggésének trendje is eltérő (Lovas et al., 2010). Az egyes rétegek eltérő felmelegedése mechanikai stresszhatásokat okoz és az ennek hatására létrejövő mikrorepedések a feldolgozási technológia következő lépcsőjében, az aprítás során, a törési munka szükségletet csökkentik.

A hagyományos hőközlési eljárásokhoz képest a mikrohullámú eljárás előnyei, hogy nem szükséges a kezelt kőzet teljes tömegét felmelegíteni és a szelektív felmelegedés következtében az energia nagyobb arányban fordítódik a kristály rácsszerkezetének bontására, mint hőkeltésre, így nincs szükség magas hőmérséklet alkalmazására sem. Ezen kívül a mikrohullámú módszer alkalmazásánál nincs szükség közvetítőközegre (energiatranszport a hőtranszport helyett) és a kezelés elindítása és leállítása rövidebb időt vesz igénybe, mint a klasszikus hőkezelésnél (felfütési és lehütési szakasz nagymértékben lerövidíthető) (Haque, 1999). Az ásványok közül a szénalapú, fémoxid, szulfid és arzenid alapúak magas, míg például a szilikát, karbonát és szulfát alapú ásványok alacsony mikrohullámú energiaabszorpcióra képesek (Kingman et al., 1999).

A széntartalmú kőzetek feldolgozása során is sikeresen alkalmazták a mikrohullámú hevítést. Az aprítási energiaszükséglet csökkentése érdekében alkalmazott hagyományos termikus kezelésekkor a felmelegítés energiaszükséglete meghaladja az aprítási energiaszükséglet csökkenését. Mivel a szén dielektromos veszteségi tényezője magas, a mikrohullámú sugárzás hatására nagy behatolási mélység mellett gyorsan és magas hőmérsékletre melegszik fel relatívan alacsony besugárzott teljesítmény mellett, amely energiahasznosulási szempontból kedvező (Marland et al., 2000). Ebben az esetben a további feldolgozás során alkalmazott aprítás energiaszükséglet csökkenése már meghaladja a mikrohullámmal végzett termikus kezelés energiaigényét. 
A kőszén mikrohullámú kezelésénél a nagymértékü felmelegedés következtében a kőzetben lévő víztartalom helyben fázisváltozást szenved és a keletkező pára nyomásnövekedése tovább fokozza a kőzetben ébredő mechanikai feszültségeket, amely az aprítási teljesítményigényt méginkább csökkenti. A vasérc feldolgozása esetében az előkezelésként alkalmazott mikrohullámú sugárzást a pirit nagyobb mértékben nyeli el, mint a kőszén és a pirit a rövid idő alatt lebomlik, amely gyors kéntelenítést tesz lehetővé (Weng and Wang, 1992).

A szén magas mikrohullámú energiaabszorpciós tulajdonsága az aktív szén előállítás és regenerálás során is jól felhasználható. Az aktív szén előállításakor elsősorban a hagyományos hőkeltést alkalmazó pirolízishez képes a nagymértékben lerövidülő folyamatidő az, amely egyrészt a kapacitást növeli, másrészt a költségeket csökkenti (Vass et al., 2005). Ez nemcsak a rövidebb melegítési időben és a kezelt réteg egyenletesebb átmelegedésében jelentkezik, hanem ennek következtében a lényegesen alacsonyabb inert gáz szükségletben is (Menendez et al., 1999). Meg kell azt is jegyezni, hogy a mikrohullámú hőkeltő berendezések mérete is jelentősen kisebb, mint a hagyományos hőkezelő berendezéseké, amely üzemi körülmények között a technológia területigényét is csökkenti. Mivel a mikrohullámú hőkeltésnél közvetítő közeg sem szükséges, így például a hevítést alkalmazó műveletekben keletkező utókezelendő (hűtés, tisztítás stb.) gázok térfogata is kisebb.

Az aktív szén töltetek újrahasznosításánál már a különböző hevítési módszerekkel történő előállítás részletes, összehasonlító vizsgálatait megelőzően is tapasztalták, hogy a mikrohullámú sugárzással történő regenerálás deszoprciós hatékonyságát és energetikai paramétereit tekintve is, kedvezőbb, mint a hagyományos hevítés. Ennek oka lehet az adszorbeálódott vegyület magas dielektromos vesztesége. A gáztisztítási eljárásokban használt granulált aktív szén szürők nitrogén-oxidokat $\left(\mathrm{NO}_{\mathrm{x}}\right)$ megkötő felülete például nagyobb arányban abszorbeálja a mikrohullámú energiát, így a közölt energia nagyobb része fordítódik ténylegesen a telített rétegek hevítésére. A kezelt aktív szén felületének adszorpciós kapacitása emellett nem romlik, illetve a fajlagos felület egyes esetekben növekszik (Kong and Cha, 1996).

Az illékony szerves vegyületekkel (VOC) szennyezett aktív szén mikrohullámú regenerálása esetében azonos tapasztalatokra jutottak, mint a nitrogén-oxid szennyezők deszorpciója során (Coss and Cha, 2000). A polimer adszorbensek a mikrohullámú 
sugárzást áteresztik, így az energia elnyelődés gyakorlatilag egészében az adszorbeálódott szennyezőanyag rétegben valósul meg. A mikrohullámú regenerálás az aktív szén esetében kialakuló $\quad 1400-1600^{\circ} \mathrm{C}$-al szemben a polimer adszorbenseknél kb. $250-350 \quad{ }^{\circ} \mathrm{C}$ hőmérséklettartományban történik (Oppermann and Brown, 1999).

A mikrohullámú sugárzás oxidációs eljárásokkal történő kombinációjával kapcsolatban is több területen folynak kutatások. A hidrogén-peroxidot alkalmazó víztisztítási eljárások esetében az egyik legnagyobb hátrányként emelik ki, hogy a folyamat jó hatásfokkal csak savas kémhatású reakcióközegben hajtható végre. Azonban kálium-perszulfát oxidálószert mikrohullámú sugárzással együtt alkalmazva a nehezen lebomló perfluoro-oktánsav, az insecticid hatású dimetoát származékok és az azoszínezékek lebontására a természetes vizek semleges közeli pH-ján is jó hatásfokkal volt alkalmazható a peroxidos módszerrel összehasonlítva (Lee et al., 2009). A mikrohullámmal intenzifikált Fenton reakció hatékonyságának elemzése során megállapították, hogy a hagyományos eljárásokhoz képest a mikrohullámú hőkeltés tömörebb pelyheket eredményezett, ami a további szeparációs mủveleteket (ülepítés, membránszürés) megkönnyítette (Yang et al., 2009).

A mikrohullám a katalitikus folyamatokban is jó hatásfokkal alkalmazható például fenol, klórozott szénhidrogének gyógyszermaradványok eltávolítására. A platina vagy a réz alapvetően reflektáló tulajdonságú az elektromágneses térben, azonban ha a fémkatalizátor részecskék átmérője kisebb, mint a penetrációs mélység az adott frekvencián, a mikrohullám a részecskehalmazon keresztülhatol. Ezt a jelenséget használják ki az aktív szén részecskék felületére felvitt fém-katalizátorok esetében is: a szén az igen gyors felhevülése révén biztosítja az elegendően magas hőmérsékletet a katalizátor számára. Ezekben az aljárásokban az aktív szén, illetve a granulált aktív szén egyaránt adszorbensként és (mikrohullámú sugárzás-) abszorbensként is funkcionál (Bo et al., 2008). A Magtrieve $^{\mathrm{TM}}$ króm-oxid katalizátort kifejezetten a mikrohullámú térben, alkoholok és szénhidrogének heterogén katalízissel történő oxidációs eljárásaira fejlesztették ki. Alkalmazásával nagyon rövid idő alatt lehet a reakcióelegyet a kívánt hőmérsékletre felmelegíteni, és az energiahasznosulási mutatók kedvezőbbek, mert az elegy átlaghőmérsékletéhez képest a poláris tulajdonságú katalizátor magasabb hőmérsékletre melegszik (Bogdal and Loupy, 2008). Titán-dioxid katalizátor esetében kimutatták, hogy a mikrohullámú sugárzás hatására, a hagyományos felmelegítéstől nagyobb mértékü hidoxil- 
gyök képződésen túl, a katalizátor felülete hidrofóbbá vált, ami az eltávolítandó anyag és a katalizátor összekapcsolódását segíti elő (Remya and Lin, 2011).

\subsubsection{A mikrohullámú sugárzás hatásai a biológiai rendszerekre}

A mikrohullámú sugárzás biológiai rendszerekre gyakorolt hatásai talán - ha nem is a legtöbbet kutatott -a legellentmondásosabb területe a kutatásoknak. Az élő rendszerek tekintetében az egyik kiemelt téma a mikroorganizmusok szaporodására gyakorolt hatás vizsgálata. A mikroorganizmusok egyes törzsei a rövid osztódási ciklusuk, pH- és hőmérsékletérzékenységük miatt jó tesztkörnyezetet biztosítanak a mikrohullámú sugárzás termikus és nem-termikus hatásainak vizsgálatára.

A rendelkezésre álló, több évtizedes kutatási eredmények alapján azonban ellentmondások tapasztalhatóak annak tekintetében, hogy a hagyományos és egyéb sugárzásos hőkeltésen alapuló termikus eljárásokhoz képest a mikrohullámú sugárzás rendelkezik-e egyértelmüen speciális hatással.

Az élő mikroorganizmusok esetében a kutatások megállapították, hogy a hagyományos hőkezelés esetében befolyásoló tényezőkön - hőmérséklet, hőkezelési idő, nyomás - kívül egyéb paraméterek is hatással bírnak a mikróbák pusztulására, illetve a szaporodásuk gátlására. Ilyen tényezők például a sugárzás frekvenciája, a mikrohullámú teljesítmény, vagy a kezelt rendszerek dielektromos szempontból értelmezett komplexitása (Fujikawa et al., 1992; Banik et al., 2003; Shamis et al., 2012a). A mikrohullámú energiaközlés továbbá alkalmas a mikróbaszám csökkentésen kívül a nemkívánatos enzimes folyamatok gátlására is, rövid műveleti idővel (Szabó et al., 1998b). Mivel a mikroorganizmusokra gyakorolt hatás vizsgálata az esetek döntő többségében vizes fázisban, vagy nagy víztartalom mellett történt, és mivel a poláros tulajdonságú vízmolekula jól abszorbeálja az elektromágneses spektrum mikrohullámú tartományát és ezáltal igen rövid idő alatt gyors felmelegedés tapasztalható, egyes szerzők az eltérő mikróbapusztulási dinamikát a hagyományos hőkezeléstől eltérő felmelegedési sebességgel és a hőmérsékletmező eltérő homogenitásával magyarázzák (Kozempel et al., 2000). A felmelegedési sebességet a rendszerben, illetve az anyagban lévő víz abszolút mennyiségén kívül annak kötési állapota (szabad, vagy kötött víz) is befolyásolja. 
Más szerzők bizonyítottnak látták a mikrohullámú sugárzás nem-termikus hatását a csíraszám-csökkentési eljárásokban. Shamis et al. (2009) Escheria coli esetében a baktériumra jellemzően megadott minimális pusztulási hőmérséklet $\left(45^{\circ} \mathrm{C}\right)$ alatti, $18 \mathrm{GHz}$ frekvenciájú mikrohullámú kezelések során már csíraszám csökkenést tapasztaltak, amely a nem-termikus hatásmechanizmusok létezését támasztja alá. A sejtekben bekövetkező változások müszeres vizsgálati módszereinek fejlődésével lehetőség nyílt a mikrohullámú sugárzás hatásának részletesebb vizsgálatára is. Lézer scanning mikroszkópos vizsgálatokkal kimutatták, hogy mikrohullámú kezelések során az élő sejtek sejthártyáiban pórusok képződnek, és ez a sejtmembrán anyagtranszportjára hatással vannak, amely morfológiai változás a sejt ideiglenes dehidratációjához és a sejten belüli nyomás megváltozása révén a sejt alakjának megváltozásához is vezet. A vizsgálati eredmények alapján továbbá feltételezték, hogy a vizes közegben lévő sejtek szaporodásának és anyagcseréjének megváltozása a vízmolekulák jó mikrohullámú abszorpciója következtében létrejövő elektrokinetikus mechanizmusokra és ozmotikus viszonyok megváltozására vezethető vissza (Shamis et al., 2011).

Az enzimes folyamatoknak, illetve ehhez kapcsolódóan a fehérjék térszerkezetének a változó nagyfrekvenciás térben történő megváltozását is több kutatócsoport vizsgálta. A leggyakrabban alkalmazott mikrohullámú frekvencián $(2,45 \mathrm{GHz})$, kis hőmérsékletemelkedést $\left(<0,5^{\circ} \mathrm{C}\right)$ elérve, a besugárzott $\beta$-laktoglobulinban a fehérjeszerkezet konformációs megváltozását figyelték meg, amely „hideg” denaturációt okozott, és amely a hagyományos felmelegítéssel kivitelezett, azonos végleges átlagos hőmérséklet esetén nem volt tapasztalható (Bohr \& Bohr, 2000a). A kutatók a hatásmechanizmust az alkalmazott elektromágneses sugárzás frekvenciájának, és a fehérje saját rezonancia frekvenciájának (2 GHz) egybeesésével magyarázták (Bohr \& Bohr, 2000b). Ebben az esetben természetesen figyelembe kell venni, hogy a besugárzási frekvencia $(2,45 \mathrm{GHz})$ a kezelt, dielektromos szempontból veszteséges rendszerben csillapodik, azaz a frekvenciája csökken, vagyis a mikrohullámú magnetron frekvenciáján kívül, a kezelt mátrix dielektromos tulajdonságai is befolyásolják a két frekvenciatartomány szükségesen elérendő azonosságát.

Az enzimeket tartalmazó folyékony halmazállapotú rendszerek mikrohullámú kezelése esetében az enzimek koncentrációja kevésbé, azonban az egyéb komponensek például a különböző sók jelenléte nagyobb mértékben meghatározó az aktivitás szempontjából. Az egyes enzimek esetében a hősokk hatására létrejövő inaktiválódása, illetve bizonyos 
hőmérséklettartományban tapasztalható aktivitás növekedés szempontjából az egyéb komponensek fajtája és koncentrációja eltérő hatású lehet. A termostabil enzimek nagyfrekvenciás elektromágneses térben történő kezelésének vizsgálata során Porcelli et al. (1997) már egy korai munkájában rámutatott, hogy a szubsztrátként, illetve a folyamat optimális pH tartományának biztosítására szolgáló kálium-dihidrogén foszfát adagolása egyes esetekben csökkenti, a kálium-klorid növeli az inaktiváció mértékét. A jelenség magyarázata feltehetőleg a szubsztrát enzimhez kötődésekor stabilizálódó térszerkezetben keresendő.

A citrát-szintáz enzim müködésének és aktivitásának vizsgálata során George et al. (2008) megállapították, hogy a mikrohullámmal azonos hőmérsékletre melegített elegy esetén az enzim-fehérje kötési tulajdonságok kedvezőbbek voltak, mint hagyományos felmelegítés esetén, amely alapján bizonyítottnak látták a mikrohullám nem-termikus hatásmechanizmusainak létezését. Az elektromágneses tér nem-termikus hatásaiból eredő enzimaktivitás növekedésről számolnak be Shamis et al. (2012b) citokróm-oxidáz és laktátdehidrogenáz, illetve Lakatos és mtsai. (2009) celluláz enzim esetében. A hagyományos (konvektív, konduktív) hőközlési eljárások és a mikrohullámú hőkeltés összehasonlító vizsgálatai során azonban figyelembe kell venni, hogy azonos véghőmérséklet értékek elérése ellenére a felmelegítési sebesség és a hőmérséklet homogenitása még kevertetett-, illetve átáramlásos rendszerek esetében is eltérő. A hőmérséklet profilok azonosságának biztosítását továbbá a mikrohullámú térben való pontos hőmérsékletmérés problémája is nehezíti.

\subsubsection{A mikrohullámú sugárzás nem-termikus hatásai}

A mikrohullámú sugárzás ún. nem-termikus, vagy specifikus hatásainak léte és létezésük bizonyítása az egyik legvitatottabb területe a mikrohullámú kutatásoknak. A mikrohullámnak a kezelt anyagra gyakorolt hatásainak megítélésénél fontos tényező a vizsgálat során alkalmazott teljesítmény, vagy intenzitás. Nagy energiájú kezelések esetén a dielektrikumok rövid idő alatt felmelegednek és figyelembe véve a mikrohullám speciális hőkeltési mechanizmusát, az elektromágneses tér inhomogentásait, a dielektromos tulajdonságok nem-lineáris hőmérsékletfüggését és ezeknek a hőtani paraméterekkel nem minden esetben egyértelmü összefüggéseit a termikus és a nem-termikus hatások szétválasztása nehézkes (Remya and Lin, 2011). 
A hagyományos hőközlési módszerekkel történő összehasonlítás nehézségét adja továbbá, hogy azonos felmelegedési sebesség azonos energiaáram biztosítása mellett, valamint a stacionaritás (nemcsak pusztán hőtani) értelmezése és definiálása a mikrohullámú energiaközléses eljárásoknál nehézkes. További technikai problémákat vet fel a mikrohullámú térben való hőmérsékletmérés. Ha manapság már rendelkezésre is állnak olyan módszerek, amelyek lehetővé teszik a mikrohullámú térben történő alkalmazást és a real-time adatfeldolgozási eljárást, a termikus egyensúly elérése a nagyfrekvenciás változó térben nehézkes és a szenzorok legtöbb esetben az elektromágneses tér perturbációját okozzák.

A másik lényeges tényező, hogy a vizsgálatokat milyen tulajdonságú rendszerben végzik. Az apoláris vegyületek mikrohullámú energiaabszorpciója a poláris vegyületekhez képest sok esetben elhanyagolható, azonban nem nulla. A transzparens anyagok egyedül, vagy heterogén rendszerek alkotóiként alapvetően energiát nem nyelnek el, vagyis veszteségmentesek, de heterogén rendszerben az elnyelök felmelegedését követően az egyéb hőátviteli mechanizmusok révén azok is felmelegednek, a növekvő hőmérséklet pedig legtöbbször a mikrohullámú energiaabszorpciójuk hatásfokát növeli.

A nem-termikus hatások meglétét egyes kutatások csak oldószert nem tartalmazó rendszerekben, illetve viszkózus vagy kétfázisú rendszerekben látják igazoltnak (Herrero et al., 2008), míg más vizsgálatok során oldatok és szuszpenziók esetében is közöltek a hagyományos hőkeltéstől eltérő, „mikrohullám-specifikus” hatásokat. Folyékony élelmiszerek folyamatos üzemü pasztőrözése során a hagyományos termikus és a mikrohullámú módszer mikróbapusztító hatásában lényeges eltérést nem tapasztaltak, de a kezelt tej, illetve narancslé komponenseinek kémiai változásait kolorimetriás mérésekkel alátámasztották (Géczi et al., 2013).

A szerves-kémiai szintéziseknél sok esetben a mikrohullámú energiaközlést előnyösebbnek találták a képződött vegyületek mennyisége és/vagy minősége szempontjából. Ciklo-addíciós reakciók esetében megállapították, hogy a mikrohullám alkalmazásával, különösen apoláris oldószerekben, a reakciósebesség magasabb, mint a klasszikus hőntartási módszer esetében (de la Hoz, 2005). 
A mikrohullám egyedi hőkeltési mechanizmusa révén az energiát abszorbeáló molekulák a nagyfrekvenciával változó elektromágneses térben intenzíven melegednek, a kialakuló pillanatnyi hőmérsékletmező térben nem homogén, és ez a felmelegés következtében megváltozó dielektromos tulajdonságok időbeni változása is követi, vagyis ún. „hot-spot”-ok jönnek létre. A rendszer egyes pontjainak pillanatnyi hőmérséklete nem mérhető, mivel ez a teljesítménytől, az anyagban kialakuló térerősségtől függ, amelyet meghatároznak a - hőmérséklettől és anyagi tulajdonságoktól, összetételtől és halmazállapottól függő - dielektromos anyagi jellemzők. A „hot-spot”-okban kialakuló becsült hőmérséklet figyelembevételével korrigált, későbbi modellek azonban a különböző melegítési eljárásokat alkalmazó reakciók kinetikájában nem mutattak különbséget, illetve a különbség a többkomponensü rendszerek egyes összetevőinek eltérő felmelegedésének következménye volt (Constable et al., 1992; Hajek, 1997). Meg kell azonban jegyezni azt is, hogy a „hot-spot”-okban a fötömegnél magasabb - de méréssel nehezen meghatározható - hőmérséklet lokális hőmérsékletgradiens kialakulásához vezet, amely befolyásolja például a hőmérsékletfüggő katalitikus folyamatok sebességét, sőt egyes esetekben a reakcióutakat is.

Egyes elméletek szerint a gyorsan változó elektromágneses tér polarizálja a molekulákat, amelyek mobilitása megnövekszik, továbbá forgásuk következtében nemcsak felmelegednek, hanem találkozási-kapcsolódási valószínűségük is nagyobb, ezért az egyes reakciók sebessége fokozódik, az aktivációs energia pedig csökken (Miklavc, 2001).

Aktív szén mikrohullámú kezelésekor, a hagyományos hőközléshez képest tapasztalt magasabb adszorpciós képességet is a hőmérsékleti hot-spotok létrejöttével hozták összefüggésbe. A feltételezett reakciómechanizmus szerint a delokalizált elektronok kinetikai energiája a nagyfrekvenciás mikrohullámú térben olyan mértékben növekszik, amely hatására az elektronok az anyagból a környező levegőbe lépnek ki, azt ionizálják. Ennek következtében a hot-spotokban plazma-állapot jön létre, amely szinte teljes energia abszorpciót okoz, így a lokális hőmérséklet igen rövid besugárzási időt követően $1000^{\circ} \mathrm{C}$ fölé emelkedik (Menendez et al., 2008). Feltételezve a mechanizmus helyességét, a kezdetben nem-termikus hatás következtében az anyagon belül intenzív hőtranszport indul meg. 
A mikrohullámú sugárzás hatással van a szerves kémiai reakciókban létrejövő vegyületek térizomériájára is, mivel befolyásolja az egyes reakcióutak valószínüségét (Hoz et al., 2004). Az elektromágneses térnek a fotokémiai reakciókra gyakorolt hatása is igazolt, mivel a gyökképződési mechanizmusokra, illetve ezek sebességére egyaránt hatással van, és segítségével a gyökpárok rekombinálódása befolyásolható, amely elektron spin rezonancia változás alapján, nyomon követhető (de la Hoz et al., 2005).

Kvantumkémiai modellezés és a különböző szerveskémiai szintézisek eredményeinek figyelembevételével a következő fontosabb megállapítások születtek a mikrohullám termikus és nem-termikus hatásaira vonatkozóan (Aklhori et al. 2002; Loupy et al., 2004):

- Gázfázisú reakciókban az elektromágneses tér dipólus indukációja a mikrohullámú energia elnyelődését fokozza.

- Folyadékok esetében a reakciókomplex saját rezgési frekvencájának és az elektromágneses tér frekvencia tartományának egybeesésekor a reakcióutak és a térizoméria eltérhetnek a hagyományos eljárások esetében tapasztaltaktól.

- A rendszerekben lévő oldószerek tulajdonságai, illetve ezek változásai (dipólusmomentum, polaritás stb) elfedik az esetlegesen létező nem-termikus hatásokat. A kémiai reakciókra gyakorolt hatások tehát oldószermentes körülmények között vizsgálhatóak.

- A mikrohullámú tér a molekulák esetében elősegíti a polarizálódást és a poláris köztestermékek stabilitásának növekedését okozza. 


\subsection{Mikrohullámú technika alkalmazása a szennyvíziszap-kezelésben}

A szennyvíziszapok mikrohullámú kezelésére vonatkozó kutatások viszonylag rövid, körülbelül egy évtizedes múlttal rendelkeznek. A fejezetben röviden összefoglalom az iszapkezelés lehetséges eljárásait, majd a mikrohullámú iszapkezelések eddigi eredményeit részletsebben elemzem.

\subsubsection{Szennyvíziszapok és kezelési lehetôségeik}

A kommunális és ipari szennyvíztisztítási eljárásokban egyaránt nagy mennyiségü és legtöbbször magas víztartalmú iszap keletkezik. A szennyvíziszap összefoglaló név alatt egyaránt értik az mechanikai szennyvízkezelési eljárásokban keletkező iszapot, és a biológiai szennyvíztisztítás, vagy a fizikai-kémiai szennyvíztisztítás során keletkező iszapot is. A szennyvíziszap fogalom ezért eléggé széleskörüen értelmezett.

Az 50/2001 (IV.3.) Kormányrendeletben megfogalmazott definíció alapján az iszap a kommunális szennyvíz tisztítási eljárásaiban képződő, valamint az az ehhez hasonló összetételü szennyvizeket kezelő szennyvíztisztító létesítményekből és berendezésekből származó iszap és a településeken keletkező folyékony halmazállapotú hulladék. Ezen csoporton belül a biológiai-, kémiai-, illetve termikus módszerekkel, vagy más „,megfelelő” eljárással (például komposztálás, vagy anaerob fermentáció) - továbbá a települési folyékony hulladékok tekintetében tartós (minimum 6 hónap) tárolásával, vagy kémiai módszerekkel - kezelt iszapok nevezhetőek szennyvíziszapnak, ha a rendeletben rögzített mikrobiológiai- és szennyezőanyag tartalomra vonatkozó előírásoknak megfelelnek.

Hétköznapi, vagy a tudományos közéletben használatos definíciók ennél tágabb értelmezésűek. A szennyvíziszap a szennyvízkezelés során kiválasztott nagy víztartalmú hulladék (Fodor, 2001). A tudományos közleményekben egy szintén az előzőektől eltérő aspektusok alapján megfogalmazatott definícióval találkozunk, miszerint a szennyvíziszap a szennyvízkezelési eljárásokban keletkező minden „félig szilárd” halmazállapotú maradvány (International Water Associacion (IWA) -Nemzetközi Víz Szövetség- 'Water wiki’ tudástárának definíciója).

A szennyvíziszapok, a szennyvizek keletkezésének helye és ezek összetétele, valamint a szennyvízkezelési technológiák és az iszap-előkezelési eljárások sokfélesége miatt eltérő összetétellel rendelkeznek, amely az átmeneti tárolás, vagy a deponálás során lejátszódó 
biokémiai folyamatok miatt tovább változhat. A szennyvíziszapokat legtöbbször a hasznos, vagy hasznosítható komponenscsoport, illetve az ún. korlátozó összetevők csoportja alapján szokták megkülönböztetni (Barótfi, 2000).

1. táblázat. A szennyvíziszapok általános összetétele

\begin{tabular}{|c|c|c|}
\hline \multirow{11}{*}{$\begin{array}{c}\text { Hasznos(ítható) } \\
\text { anyagok }\end{array}$} & \multirow{4}{*}{ Víz } & pórusvíz \\
\hline & & kapilláris-víz \\
\hline & & iszappelyhekbe zárt víz \\
\hline & & kémiailag kötött víz \\
\hline & \multirow{2}{*}{ Ásványi részecskék } & finom és durva homok \\
\hline & & egyéb részecskék \\
\hline & Szerves anyagok & széntartalmú vegyületek \\
\hline & \multirow{3}{*}{ Tápanyagok } & nitrogén \\
\hline & & foszfor \\
\hline & & kálium \\
\hline & Nyomelemek & fémes elemek, szerves anyagok \\
\hline \multirow{5}{*}{$\begin{array}{l}\text { Korlátozó } \\
\text { összetevők }\end{array}$} & \multirow{2}{*}{ Toxikus anyagok } & nehézfémek (pl.: Cd; $\mathrm{Pd} ; \mathrm{Cu} ; \mathrm{Hg}$ ) \\
\hline & & egyéb toxikus anyagok (pl.: As; Mo) \\
\hline & \multirow{3}{*}{ Patogének } & paraziták \\
\hline & & baktériumok \\
\hline & & vírusok \\
\hline
\end{tabular}

Az iszapok általános összetételének figyelembevételével megállapítható, hogy az összes víztartalom 90\%-át kitevő pórusvíz és a kapilláris-víz egyszerübb mechanikus és termikus elválasztási módszereket alkalmazva eltávolítható. Az iszapokban lévő víztartalom fiziko-kémiai állapotát a többi összetevő is meghatározza, ami a további sürítési és víztelenítési eljárások hatásfokát is befolyásolja. A csoportosítás viszonylagos, mivel például a kommunális iszapok esetén korlátozónak tekintett nehézfémek egy ipari eredetü iszap esetében hasznosíthatóvá tehetők.

Az iszapot alkotó részecskék szemcsemérete és szemcseeloszlása is függ az iszap jellegétől. Az előülepítőkből származó friss iszap szárazanyag tartalmának 9-33\%-át a 1017 mm közötti, 5-20\%-át a 1-10 mm-es, és 50-88\%-át az 1 mm-nél kisebb részecskék teszik ki. Az eleven iszapban ezzel szemben az 1 mm-nél kisebb méretű részecskék aránya eléri a $98 \%$-ot is. A kirothasztott iszap esetében az 1 mm-nél kisebb részecskék aránya körülbelül 85\% (Vermes, 2005). 
Az ipari, és ezen belül az élelmiszeripari szennyvíziszapok esetében nem állnak rendelkezésre olyan általános összetételi adatok, mint a kommunális szennyvíziszapok esetében. Ennek oka egyrészt a szennyvizet produkáló technológiák sokfélesége, a szennyvízkibocsátás mennyiségi és minőségi fluktuációja, az eltérő gyüjtési- és átmeneti tárolási rendszerek felépítése és müködtetési gyakorlata, továbbá maga a szennyvíztisztítási technológia (nincs, mechanikai, kémiai, vagy biológiai tisztítás, vagy ezek kombinációi) és ennek hatásfoka, illetve az iszapkezelési eljárások típusa (sűrítés, víztelenítés, kémiai kondicionálás, termikus kondicionálás) és ezek hatékonysága.

A feldolgozott alapanyagokat tekintve, mivel ezek a szennyvíz és ezáltal az iszap összetételét is meghatározzák, az élelmiszeripari technológiákból származó iszapok növényi nyersanyagok esetében magas szénhidrát, állati eredetű alapanyagok esetén magas fehérjetartalommal, és emellett számottevő zsírtartalommal rendelkeznek. Az egyes alapanyagcsoportokat felépítő elemek (szén, hidrogén) számítható elméleti biogázkihozatali mutatói azonban a valós mutatókat jelentősen meghaladják.

Ennek oka egyrészről a biológiai lebontás szempontjából nem optimális elem összetétel, az illékony és könnyen bomló komponensek tárolás és kezelés közbeni elvesztése, a biokémai folyaamtok közben az iszap pH-jának csökkenése. A szervesanyagok hasznosulását szintén befolyásolja az iparágra jellemző biológiai és biokémiai folyamatokat gátló vagy megváltoztató adalék- és segédanyagok (fertőtlenítőszerek, detergensek, tartósítószerek) jelenléte.

Mindezen okokból kifolyólag az élelmiszeripari anyagok esetében bizonyított, hogy hatékony anaerob fermentációs hasznosítás csak megfelelő előkezeléseket követően lehetséges (Iacovidou et al., 2012). A húsfeldogozási folyamatok szennyvíz, valamint az ebből fázisszeparálással keletkező iszap főbb komponenseinek jó biológiai lebonthatósága ellenére, a magas KOI-ban mért szervesanyagtartalma mellett a vártnál alacsonyabb, valóban lebomló - BOI-egységben mérhető - szervesanyag hányaddal rendelkezik (Bohdziewicz and Sroka, 2006; de Sena et al., 2008).

A kommunális iszapok esetében a további aerob és anaerob folyamtokban való hasznosítást (komposztálás, illetve biogáz fermentáció) az optimálisnál (20-30:1) alacsonyabb C:N arány nehezíti, ez az élelmiszeripari szennyvíziszapok, elsősorban az állati eredetü nyersanyagokat feldolgozó iparágak (hús-, baromfi- és tejipar) esetében kevésbé okoz problémát (Kim et al., 2003). Azonban az élelmiszeripari eredetű iszapoknál 
meghatározó a rothasztás, vagy egyéb biológiai hasznosítás hatékonysága szempontjából a magas fehérjetartalom következtében magas az extracelluláris polimer szerkezeti mátrixot képző anyagok (EPS) aránya, valamint a hidrolízis folyamatának a lebontási időre, illetve ütemre gyakorolt jelentős hatása (Eskicioglu et al., 2008; Mottet et al., 2009).

Az élelmiszeripari szennyvizek és szennyvíziszapok összetételét tekintve kiemelhető továbbá a kommunális iszapoktól eltérő, magasabb kation koncentráció. A kationok jelenléte a mikrobiális folyamatokban, a mikróbák szaporodásában meghatározó, azonban a túl magas koncentrációjuk, a kedvezőtlen ozmotikus körülmények kialakulása miatt, már az anaerob lebontási folyamatokban kedvezőtlennek tekinthető. A hosszú szénláncú zsírsavak és az ammónia, amelyek aránya a húsipari szennyvíziszapokban magas, az elméleti magas metánkihozatali mutatók mellett, az anaerob fermentációban inhibiáló hatásúak lehetnek (Chen et al., 2008). Az élelmiszeripari feldolgozási technológiákban mosásra, illetve fertőtlenítésre használt detergensek (anionos és nem ionos, illetve kationos) a szennyvíziszapba, majd az iszaprothasztókba kerülve az üzemeltetési problémákhoz vezető habképződési hajlamot növelik (Ganidi et al., 2009).

$\mathrm{Az}$ iszapkezelési eljárások az azokat felépítő műveletek és a használt berendezések alapján a következő csoportokba oszthatóak:

Sürítés

- Gravitációs sürítés

- Flotációs sürítés

- Dinamikus sürítés (vibráció, centrifuga)

- Sürítés szüréssel

Kondicionálás

- Elutráció (iszapmosás)

- Termikus kondicionálás (160-220 C, több lépcsőben)

- Pasztőrözés $\left(60-80^{\circ} \mathrm{C}\right)$

- Biokémiai kondicionálás

- Kémiai kondicionálás (pl.: polielektrolit, vas- és aluminium klorid)

Fertőtlenítés

- Klóros oxidáció

- Hőkezelés

- Meszes kezelés

- Besugárzás, ultrahang 
Iszapvíztelenítés (kondicionált iszap)

- Természetes (szikkasztó ágy és tavak, szoláris szárítás)

- Mesterséges víztelenítés

- Dinamikus (centrifuga, szeparátor)

- Statikus (szalagszürők, kamrás szürők)

- Szívóerő alkalmazása (vákuum szürés)

- Kombinált eljárások

Szárítás $\left(85-400^{\circ} \mathrm{C}\right)$

- Szalagos szárító

- Füstgáz-szárító

- Etage kemence

- Forgó csőkemence

Égetés

- Önálló égetés pót-tüzelőanyaggal

- Települési hulladékkal együttégetés

- Ipari hulladékkal történő együttégetés

\section{Pirolízis}

Komposztálás

Anaerob stabilizálás biogáz-fermentációval

Deponálás

A szennyvíziszap kezelési eljárások többségében a nedvességtartalom csökkentését végzik, elsősorban térfogat-csökkentési célzattal. A szennyvíziszap víztelenítése, a víz különböző fiziko-kémiai állapotai miatt, sok esetben nehézkes, a kötött víztartalom egy részét az önállóan alkalmazott hagyományos víztelenítési eljárásokkal nem lehet eltávolítani. A magasabb szárazanyag tartalom elérése érdekében különböző előkezelési eljárásokat alkalmaznak, amelyek fó célja az iszap szerkezetének megváltoztatása. Az anaerob fermentáció, illetve az egyéb energetikai hasznosítás esetén ki kell emelni, hogy ezek alkalmazásával a szennyvíztisztító telepek kilépnek a csupán szennyezőanyag tisztításra koncentráló, ún. „end-of-pipe” technológiák közül. Az iszappelyhek dezintegrálódásával, illetve a baktériumok sejtfalának sérülésével a sejtnedv kiszabadul, amely egyrészt a nedvességtartalom eltávolítását könnyíti meg, másrészt a biológiai ártalmatlanítási és egyéb iszapkezelési eljárásokban a nitrogén- és foszfor így 
hasznosíthatóvá válik. A baktériumok sejtfalának sérülése a patogén mikroorganizmusok elpusztítása szempontjából is meghatározó.

Az iszap előkezelési eljárások a következő csoportokba oszthatóak (Kepp et al., 2000; Müller, 2001)

- Termikus előkezelések: az ellenállóbb fehérjefrakciók lebontására, általában $60^{\circ} \mathrm{C}$ - $200^{\circ} \mathrm{C}$ hőmérséklettartományban.

- Kémiai előkezelések: sav, illetve lúg adagolással az elő-hidrolízis elősegítésére.

- Nagyhatékonyságú oxidációs eljárások (AOP’s): egyes iszap-komponensek, vagy a sejtfalak oxidációja és átalakítása.

- Mechanikai előkezelések: homogenizálók, ultrahangos, vagy egyéb aprítóberendezések, amelyekkel a sejtfalak integritása csökkenthető.

- Hőelvonás-fagyasztás/felengedtetés: a fagyasztás alatt a sejtnedvben kialakuló jégkristályok a sejtfalat károsítják, ezért a szabad víztartalom aránya növekszik, a sejtnedv szubsztrátként felhasználható lesz a biológiai kezelési eljárásokban.

- Biológiai/enzimes eljárások: a sejtfalnak vagy annak egyes komponenseinek lebontása a mikroorganizmusok saját enzimeinek, vagy hozzáadott enzimek/mikroorganizmusok alkalmazásával.

- Kombinált eljárások: az előző módszerek együttes, vagy egymást követő alkalmazása, például termokémiai eljárások, lúgos/savas termikus hidrolízis.

A termikus kezelések iszapszerkezetre gyakorolt - a további hasznosítás szempontjából előnyös - hatásait már több évtizede bizonyították. Brooks (1970) magas hőmérsékleten végrehajtott $\left(160^{\circ} \mathrm{C}\right.$-ot meghaladó) kommunális iszap kezelés után a szerves anyagok vízoldható fázisba kerülését figyelte meg, amely a vízteleníthetőség mértékében és a biogázhozam tekintetében is növekedést okozott. A magasabb hőmérséklet nagyobb mértékü hidrolízist eredményez, azonban már Fisher et al. (1971) és Haug et al. (1978) az iszapkezelés kutatásának egyik korai időszakából származó munkájukban is rámutattak, hogy a túl magas hőmérséklet a lebontásnak ellenálló szervesanyag frakció arányának növekedését okozza. A további anaerob fermentációban való felhasználás szempontjából kritikus előkezelési hőmérséklet értékét $175^{\circ} \mathrm{C}$-ban határozták meg. 
Az iszapkezelési eljárások ipari méretü intenzifikálására már az 1930-as években kidolgozták a Porteous technológiát, amelyet kb. $200^{\circ} \mathrm{C}$ hőmérsékleten kb. 30 perces hőntartási időt biztosítva végeztek, illetve az 1950-es évek közepén a Zimpro eljárást, amelyben kezdetben $250^{\circ} \mathrm{C}$ hőmérsékletet alkalmaztak, majd a kommunális iszapkezelési technológiákra adaptálva a kezelési hőmérsékletet, itt is $200^{\circ} \mathrm{C}$-ra, illetve ez alá csökkentették. Az anaerob rothasztási eljárást megelőző termikus előkezelések pozitív hatását nemcsak laboratóriumi, hanem ipari körülmények között is igazolták az 1980-as évek elején (pl. Haug et al., 1983), illetve a Cambi technológia alkalmazása során (Neyens, Baeyens, 2003). Az anaerob fermentációnak a termikus előkezelésekkel történő kombinálásának előnyeit a következőkben foglalták össze:

- A hőkezelési technológiában alkalmazott homogenizálás.

- A hőkezelést követően az iszappelyhek mérete csökken, ezért a biológiai folyamatok sebességét befolyásoló fajlagos felület növekszik.

- A hőkezelésnél a hő- és áramlástani viszonyok optimálásával a rothasztók fütési energiaszükséglete csökkenthetö.

- A hőkezelt iszap büzterhelése kisebb mértékü, mint a kezeletlené.

- A hőkezelést követően a vizes fázisú melléktermék (iszapvíz) mennyisége kismértékben növekszik, azonban ennek jó bonthatósága a rothasztók folyamatszabályozását megkönnyíti.

$\mathrm{Az}$ előzőekben bemutatott sikeres magas hőmérsékletü termikus iszapkezelésekkel párhuzamosan az 1980-as években találhatóak olyan tanulmányok (pl.: Hiraoka et al., 1985), amelyekben $100^{\circ} \mathrm{C}$ alatti előkezelések esetében is növekedésről számolnak be anaerob fermentációs hasznosítás esetén, azonban az eljárás legjelentősebb hátrányaként a hosszú kezelési időt említik. Mivel a legtöbb szennyvíziszap típusban az aerob mikroorganizmusok találhatóak meg nagy számban, az anaerob biológiai lebontás során először a mikroorganizmusok sejtfalaink extracelluláris enzimekkel történő lebontása történik. 


\subsubsection{A mikrohullámú iszapkezelés eddigi eredményei}

\subsubsection{Iszapszerkezetre gyakorolt hatások}

A sejtfalak lebontásának egyik gyors módszere a mikrohullámú energiaközlés. A mikrohullámú sugárzás sejtkomponens szintű abszorpciója következtében a sejtállomány víztartalma halmazállapot változáson megy keresztül, ami a sejtfalra ható nyomásnak egy kritikus szintet meghaladó értéke esetén a sejtfal integritásának megszűnéséhez vezet (Lucchesi et al., 2007).

A sejtfalak és sejthártyák feltáródását követően a további degradációt a makromolekulák oldalláncainak a frekvencia függvényében változó polarizációja következtében, a hidrogénkötések felszakadása is elősegíti (Park et al., 2004). Az elsődleges kémiai kötések felszakításához a legtöbbször használatos $2450 \mathrm{MHz}$ frekvenciájú mikrohullámú sugárzás energiája $\left(1,02 \times 10^{-5} \mathrm{eV} ; 0,4-40 \mathrm{~J} / \mathrm{mol}_{\text {foton }}\right.$ az 1-100 $\mathrm{GHz}$ frekvencia tartományban) nem elegendő. A hidrogénkötések felbomlása, és az iszapban található fehérjék másodlagos- és harmadlagos térszerkezetének változása az iszappelyhek szerkezeti stabilitásának csökkenéséhez vezet (Park et al., 2010; Tang et al., 2010).

Az iszapban lévő mikroorganizmusok sejtfalak felbomlásának, valamint az iszap szerkezeti változásainak kvantitatív jellemzésére a szakirodalom a kémiai oxigénigény (KOI, ill. COD $\left[\mathrm{mgL}^{-1}\right]$, ill. $\left.\left[\mathrm{kg} \mathrm{m}^{-3}\right]\right)$ egységben kifejezett szervesanyag vízoldhatóság változását, illetve ezen belül az egyes vegyületcsoportok (fehérjék, lipidek, szénhidrátok) vízoldhatóságában végbemenő változását használja. A vízoldható fázisban lévő szerves anyagoknak (SCOD) a teljes szervesanyag koncentrációhoz (TCOD) viszonyított aránya (SCOD/TCOD) kezeletlen, friss iszap esetében alacsony, előkezelés nélküli nyersiszap esetében növekedése a - körülményektől függően aerob, vagy anaerob - spontán biológiai lebomlási folyamatok megindulását jelzi. A mikrohullámú kezelések a SCOD/TCOD arányt növelik, a szervesanyag frakción belül az egyes vegyületcsoportok vízoldhatósága azonban nem azonos mértékben változik meg.

Kommunális eredetü, másodlagos szennyvíztisztítási eljárásból származó iszapok esetében a mikrohullámú kezelések a kezdeti SCOD/TCOD arányt több mint kétszeresére 6\%-ról 15\%-ra - növelték (Eskicioglu et al., 2006), de találhatunk olyan közleményeket, amelyben körülbelül ötszörös növekményről számolnak be (Partk et al., 2004). A 
körülbelül $10 \mathrm{~W} / \mathrm{cm}^{3}$ fajlagos mikrohullámú kezelési intenzitás rendelkezik olyan mértékü dezintegráló hatással, mint a pH12 kémhatású, 60 perces lúgos kezelés.

Meg kell jegyezni, hogy a hagyományos termikus és a mikrohullámú kezelések esetében egyaránt megfigyelték, hogy a magasabb hőmérséklet nagyobb mértékü vízoldhatóság növekményt okozott, azonban a hőmérsékletnek egy kritikus érték fölé emelése után a szerves anyagok egy része elveszik (illékony vagy bomló vegyületek). Ugyan találhatóak a lúgos kezelést és az önálló mikrohullámú kezelést tekintve olyan üzemeltetési paraméterek, amelyek a szervesanyag vízoldhatóság értékének változása szempontjából ekvivalensek, azonban a kolloid mérettartományú - vízteleníthetőséget negatívan befolyásoló - részecskék szempontjából, és az egyes szerves vegyületcsoportokat külön vizsgálva, a mikrohullámú, vagy a kombinált lúgos-mikrohullámú termokémiai kezelések előnyösebbek (Dogan and Sanin, 2009).

A mikrohullámú energiaközlés hatására kommunális iszapok esetében a szénhidrátfrakciók vízoldhatóságának növekedése, kb. 10-15\%-al magasabb, mint a fehérjéké (Appels et al., 2010). A szénhidrátok oldhatósági tulajdonságaiban végbemenő változások, a szerkezeti stabilitásukat biztosító glikozidos kötéseknek a mikrohullámú energiaközlés termikus hatására történő felszakadásával magyarázható (Wennberg et al., 2006). Appels és mtsai. egy későbbi (2013) tanulmányukban arról számolnak be, hogy az összes szervesanyag frakció vízoldhatóságánál a szénhidrát összetevők oldhatósága kb. 27\%-al volt magasabb, a teljes fehérje- és szénhidrát koncentrációk abszolút értékének változása nélkül. Egy másik kutatócsoport szintén kommunális eredetü, azonban alacsonyabb szervesanyag tartalmú iszap esetében a szénhidrátok oldhatósága esetében kb. kétszeres növekedésről számol be a fehérjékhez viszonyítva közel azonos mikrohullámú kezelési intenzitás esetében (Yu et al., 2009). Azonban az egyes komponensek oldható formáinak koncentrációváltozási dinamikáját tekintve ugyanezen tanulmány a fehérjék esetében gyorsabb növekedést ír le, amely az iszappelyhek szétesésén túl, a sejtfalak felbomlását követő sejtnedv kiáramlásnak tudható be.

A fehérjék vízoldhatóságának növelése szempontjából a forrásponti hőmérséklet növekedése kritikus, mivel ezt meghaladó kezelési hőmérséklet alkalmazásakor az oldhatóság vagy csak kismértékben növekszik, vagy tovább nem nő. Ennek oka feltehetőleg abban keresendő, hogy a hőmérséklet növelés hatására a molekulák kinetikus energiája olyan mértékben növekszik meg, amely a hidrogénkötések felszakadása mellett 
egyes nem-poláris, hidrofób kölcsönhatások erősségét is csökkenti, ami a fehérjemolekulák stabilitását csökkenti (Eskicioglu 2007).

A lúgos kezelésekhez hasonlítva a mikrohullámú energiaközlés hatására, $100^{\circ} \mathrm{C}$ kezelési hőmérséklet alatt, a fehérjék vízoldhatósága körülbelül azonos mértékben növekszik, míg a szénhidrátok esetében a mikrohullámú módszer hatékonyabb (Eskicioglu et al., 2006). A mikrohullámú és a lúgos kezelések során a két eljárással kapott oldatban lévő fehérjetartalom növekedés összege elmarad a kombinált lúgos-mikrohullámú kezelés esetében mérhető oldható fehérjekoncentrációtól, ami szinergista hatásmechanizmust jelez (Dogan and Sanin, 2009).

Az iszapok mikrohullámú energiaközléssel való kezelése esetében, a termikus hatás következtében a következő folyamatok mennek végbe:

$>$ az iszappelyhek szétesése

$>$ a sejtmembrán felszakadása

$>$ a nagymolekulájú anyagok hidrolízise

A fehérjéket és szénhidrátokat is tartalmazó anyagok, mint például a kommunális és élelmiszeripari szennyvíziszapok esetében, a hidrolízis során képződő reakciótermékek vagyis az aminosavak és egyszerü szénhidrátok- együttes jelenléte, valamint a magas hőmérséklet következtében Maillard reakció megy végbe, amely a lebontásnak ellenálló komponensek arányának növekedésében is szerepet játszik (Bougrier et al., 2007; Qiao et al., 2008). A Maillard reakció termékei legtöbbször a kb 50-70 kDa molekulaméret tartományba esnek (Dwyer et al., 2008), amely az iszap esetében a vízoldható fázisban jelenik meg. A reakció a $80^{\circ} \mathrm{C}$ feletti hőmérséklettartományban megy végbe, és polimerizációs folyamatok következtében, mind az oldható fehérjék, mind a redukáló cukrok mennyiségét csökkenti (Eskicioglu et al., 2007). Ezek alapján a magas hőmérsékletü mikrohullámú kezeléseket követően szervesanyag tartalmon belül a fermentáció vagy az aerob lebontási folyamatokat inhibiáló komponensek részaránya növekszik (Hong et al., 2006).

A mikrohullámú kezelések hatására a lipideknek a sejtközötti állományban történő növekedése figyelhető meg. A sejthártya és sejtfal feltáródásával a sejtfalat alkotó foszfolipid kettősréteg is az iszapvízbe kerül, ami szintén jelentősen hozzájárul a szervesanyag tartalom vízoldhatóvá válásához. A kétértékü kationok a negatív töltésű foszfolipidekhez kapcsolódva stabilizálják a biológiai membránokat (Chu et al., 2001) , 
ezen szabad ionok - például $\mathrm{Ca}^{2+}$ - mennyiségének a kezelések hatására történő növekedése szintén az előzőekben leírt hipotézist igazolja (Ahn et al., 2009).

A mikrohullámú kezelés folyamatparaméterei hatásának megítélése már nem ilyen egyértelmű. Egyes szerzők a mikrohullámú teljesítmény növelése esetében a szervesanyagok vízoldhatóságának növekedéséről számolnak be (Climent et al., 2007; Appels et al., 2010), míg mások csökkenő tendenciákat fedeztek fel (Park et al., 2010; Toreci et al., 2009). A szervesanyag vízoldhatóság mértékének csökkenése a nyitott kezelőteret alkalmazó kísérleti mikrohullámú berendezésekben az illékony komponenseknek a párolgás során történő elvesztésével is összefüggésbe hozható. Továbbá az atmoszferikus kezelőedényzet és a pára kondenzációt és annak visszavezetését végző egységek hiánya, vagy tökéletlensége révén a kezelés közben a párolgó felület nagymértékü nedvességvesztése az iszappelyhek részleges dehidrációjához és ennek következtében agglomerációjához vezet. Ebben az esetben még az esetlegesen a kezelés után adagolt víz sem lesz képes a szerves anyagok teljes mértékü visszaoldására (Sólyom et al., 2011).

Ha a mikrohullámú kezelés esetében egy adott hőmérséklet elérése fogalmazódik meg feladatként, a mikrohullámú teljesítmény növelése és a vízoldhatóság mértékében bekövetkező változás fordított arányosságát írták le (Eskiciouglu et al., 2006; Park et al., 2010), amely az eltérő besugárzási idő hatásával magyarázható. A változások trendjét és mértékét tekintve azonban a rendelkezésre álló eredmények alapján egyértelmü megállapítások nem tehetők, mivel a vizsgált iszapok összetétele, szárazanyagtartalma, a kísérleti berendezések konstrukciója, az alkalmazott mikrohullámú teljesítménytartományok, a kezelési hőmérséklet és a hőmérséklet emelkedés mértéke, és a fajlagos mikrohullámú kezelési intenzitás szintjei eltérőek, és ezek mind befolyásolják a kezelések hatékonyságát. Továbbá a változások jellemzésére szolgáló paraméterek (COD, SCOD, PCOD) mérési-, valamint az ezekből képzett mutatók számítási metódusai sem minden esetben egyeznek meg.

Az eddigi eredmények alapján az az általános megállapítás tehető, hogy a mikrohullámú kezeléssel az iszap forráspontja gyorsan elérhető, ebben az esetben a mikrohullámú hőkeltésnél a hagyományos hőkeltési módokhoz képest nagyobb számú gócpontban létrejövő, és magasabb hőmérsékletü gőzt tartalmazó mikrobuborékok a képződő szabadgyökök mennyiségét növelik. A képződő szabadgyökökkel kapcsolatban az ultrahangos iszapkezelések esetében már kimutatták, hogy az oldhatóság mértékét növeli, 
és a mikroorganizmuok inaktiválása szempontjából is előnyös (Chu et al., 2001; Ahn et al., 2009). A mikrobuborékok és a szabadgyökök képződésében is szerepet játszanak a többkomponensű rendszerek mikrohullámú térben leírt túlhevülési jelenségei is (Saillard et al., 1995).

A nyers, előkezelést nem kapott, iszapban hidrofil tulajdonságú, hidrátburokkal körbevett kolloid részecskék vannak, amelyeket az elektrosztatikus taszítóerők tartanak távol. A nagyfrekvenciával változó polaritású mikrohullámú térben a vízmolekulák rotációja révén a hidrátburok részlegesen felbomlik, a zeta-potenciál értéke csökken, így az iszapszerkezet destabilizálódik (Jones et al., 2002).

A víztelenítési eljárásokat megelőző mikrohullámú kondicionálás esetében megfigyelték, hogy flokkulálószereket alkalmazó szennyvíztisztítási technológiából származó iszapoknál a kezelési időtartam első részében az iszappelyhek szétesnek (fragmentálódtak), de a flokkulálószerek jelenléte miatt „újrapelyhesedési” mechanizmusok játszódnak le, azonban az így létrejött pelyhek tömörebbek, ezáltal a kötött víztartalom aránya az eredetinél alacsonyabb (Wojciechowska, 2005).

A kezelési teljesítményt, vagy a kezelési időt magas értékeknek választva az iszap sejtenkívüli, polimerekből (EPS) álló mátrixa, továbbá egyes sejtes összetevőinek sejtfala felszakad, amely a szürési- vagy préselési műveleteket alkalmazó nedvességelvonási eljárások során, a képződő sok kisméretü és kolloid mérettartományú részecske miatt, az eltömődés mértékét, illetve a viszkozitást, és ennek következtében a szűrési ellenállást is növeli (Yu et al., 2009). Az iszapmátrix szerkezeti és kémiai változásai a hőkeltés hatásfokára (a dielektromos tulajdonságok változása miatt) is hatással vannak, továbbá a viszkozitás változása a (konvektív) hőtranszport intenzitását is befolyásolja (Eskicioglu, 2007). A vizet és olajos fázist is tartalmazó iszapok esetében a mikrohullám, a zsír és olajszerü összetevők eltérő dielektromos jellemzői miatt különböző mértékű felmelegedése, és ezáltal a sűrüség- és viszkozitás változás különböző mértéke következtében fokozza a fázisok szeparálódását, így a műveleti idő a hagyományos órákig tartó eljárásokkal ellentétben néhány percre csökkenthető (Országh, 2004).

A mikrohullámú kezelést követően a kezeletlen iszaphoz képest a folyadékfázisban lévő kolloid mérettartományú részesecskék magasabb koncentrációját flokkulációs tesztekkel Chi et al. (2011) is igazolták. A mikrohullámú kezeléseket követően az iszap szerkezeti változása következtében az iszap saját pehelyképzési tulajdonságai is megváltoznak. A 
termikus hatások következtében az iszappelyhek szétesnek (dezintegrálódnak), és ezzel párhuzamosan az EPS frakció koncentrációja az iszapvízben növekszik. Az extracelluláris polimerek egy kritikus koncentrációjának elérése esetén azonban újrapelyhesedés játszódik le. A deflokkulációs-flokkulációs egyensúly a mikrohullámú kezelési idő növelésével azonban felborul, a hosszú idejű, és elsősorban a magas hőmérsékletű mikrohullámú kezelések esetében már a deflokkulációs mechanizmusok dominálnak. Ezért, és az egyéb elsősorban a szénhidrát komponensek által elszenvedett - kedvezőtlen kémiai változások az iszap vízteleníthetőségét már rontják (Jones et al., 2002; Yu et al., 2009).

\subsubsection{Az anaerob fermentáció hatékonyságára gyakorolt hatások}

Az előkezelések hatékonyságának értékelése szempontjából, az egyes vegyületcsoportok esetében végbemenő koncentrációváltozások mellett nem hagyható figyelmen kívül a további hasznosítási eljárások „hatékonyságának” mértékében végbemenő változások elemzése sem. Az anaerob fermentáció során a mikrohullámmal kezelt iszapok esetében a szervesanyag-eltávolítás (lebontás) hatékonysága jobb, mint a kezeletlen iszapok esetében. A fehérjék esetében a lebomlás mértékének növekedése kb.10\%-os, a teljes oldott szervesanyag tartalom esetében kb. 20\%-os (Appels et al., 2013). Ennél - a százalékos növekményt tekintve - nagyobb arányú változások mentek végbe az illékony zsírsavak (VFAs) tekintetében. A mikrohullámú előkezelések hatására javuló biogáz-kihozatali mutatókat ezért az illékony zsírsavak koncentrációjának megkétszereződésére vezették vissza.

A biogáz produkciót tekintve a mikrohullámú teljesítmény hatásának vizsgálatával kapcsolatosan szintén ellentmondó eredmények lelhetőek fel, egyesek a képződött biogáz mennyiségének növekedését emelik ki (Toreci et al., 2009), míg mások nem tekintik szignifikánsnak ezen folyamatparaméter hatását (Eskicioglu et al., 2007). A szervesanyagok vízoldhatóságának változása és a biogáz produktum növekedése sem minden esetben mutat egyértelmü tendenciát, a vízoldhatóság mértékét már tovább nem növelő mikrohullámú kezelési intenzitás a fajlagos biogáztermelődés szempontjából még előnyös lehet.

A cellulóztartalmú anyagok etanol fermentációját megelőzően alkalmazott magasabb intenzitású, nagyobb energiasürüséggel végzett mikrohullámú kezelések a makromolekulák hidrolízisét elősegítik, viszont a hidrolitikus és egyéb degradációs folyamatokban létrejövő 
melléktermékek az élesztőgombák etanol termelési folyamatát részben inhibiálják (Binod et al., 2012). Az iszapok esetében a fajlagos (egységnyi vízoldható szervesanyag tartalomra vonatkozatott) metánkihozatal vizsgálata során ez a jelenség kevésbé jelentős (Sólyom et al., 2011). A magas szervesanyag tartalmú, és alacsony nedvességtartalmú hulladékok nyomás alatti mikrohullámú elökezelésével a szervesanyagok vízoldhatósága hatékonyan növelhető és a kötött víztartalom csökkenthető, amely az anaerob fermentáció tekintetében potenciálisan előnyösen felhasználható (Shahriari et al., 2011)

A szervesanyagok oldhatósági tulajdonságai kedvező irányú megváltoztatásának, a termikus módszereken kívüli, további gyors módszere az oxidációs eljárások alkalmazása. A mikrohullámú előkezeléseknek az oxidációs eljárásokkal való kombinációja a szennyvíziszapok esetében a szervesanyagok vízoldhatóságának növelése szempontjából előnyös. Wong et al. (2006) például $80^{\circ} \mathrm{C}$-os mikrohullámú/hidrogén-peroxidos (1:15 térfogatarányú adagolás) rövid idejü kezeléssel a teljes szervesanyag tartalmat vízoldható formába alakították.

Önmagában a szervesanyagok oldhatóságának növekedése azonban nem minden esetben arányos a biogáztermelődés változásaival, sőt a kombinált mikrohullámú-peroxidos eljárások alkalmazásával kapcsolatban mind iszapok, mind egyéb szerves hulladékok esetében az anaerob lebontás lag fázisának növekedéséről, a kezdeti gázképződési sebesség, valamint a fermentációs folyamatok stabilitásának és képződő biogáz metántartalmának csökkenéséről beszámoló munkák találhatóak (Eskcioglu et al., 2008; Shahriari et al., 2012).

A biogáz kitermelést és a metánproduktumot tekintve a mikrohullámú kezelési körülményektől és az iszap típusától függően kb 10\%-os (Dogan and Sanin, 2009), 15\%-os (Sólyom t al., 2011); 30\%-os (Eskicioglu et al., 2007); vagy 110\%-os (Mudhoo et al., 2012) növekményre vonatkozó adatokat is találunk. A mikrohullámú előkezelésnek az anaerob fermentációs folyamatokra gyakorolt hatásainak részletesebb elemzése során megállapították továbbá, hogy a kezelési intenzitás növelése a biogázképződés ütemét is fokozza (Kennedy et al., 2007), valamint az anaerob lebontás kezdeti lag fázisa kb. 40\%-al lerövidül (Mudhoo et al., 2012). Mechanikai szennyvíztisztítási technológiából származó híg, nem-víztelenített iszap (4 m/m\% szárazanyag tartalom) esetében Zheng et al. (2009) a $90^{\circ} \mathrm{C}$-on kivitelezett mikrohullámú előkezelést követően a biogáz képződési ütem 37\%-os növekedéséről, és a teljes rothasztási folyamat idejének kb. 30\%-os csökkenését írták le, a 
maximális szervesanyag lebonthatóság 85\%-ának elérése mellett. A szerves hulladékok mikrohullámú előkezelésével kapcsolatban is megállapították, hogy a folyamatos üzemü rothasztás esetében számítható rövidebb hidraulikus tartózkodási időszükséglet elsősorban nem a teljes anaerob folyamatra megadott lebomlási sebesség magasabb értékének, hanem a fermentáció első harmadában tapasztalható gyorsabb gázképződési ütemnek tudható be (Shahriari et al., 2012).

Az iszapok rothaszthatóságának javítása céljából hatékonyan alkalmazható lúgos előkezeléseknek, a reakcióidőt jelentősen lerövidítő mikrohullámú eljárással való kombinációját vizsgálva Chi et al. (2011) rámutatott, hogy a hagyományos hőközléshez képest a kombinált mikrohullámú eljárás hatékonysága mind a hőmérséklet, mind az adagolt lúg koncentrációjának változására nézve érzékenyebb. A nem lebontható komponensek képződésének csökkentése érdekében alacsonyabb adagolási dózis, és alacsonyabb kezelési hőmérséklet megválasztása indokolt a mikrohullámú hőkeltés alkalmazása során. Amennyiben a kezelt anyag összetételétől függő kritikus hőmérséklet értékét nem meghaladó mikrohullámú kezelés történt, az iszap intracelluláris szerves anyagai, a szerkezet változásai miatt, az anaerob fermentációban résztvevő savképző baktériumok számára könnyebben hozzáférhetővé válnak, amelynek következtében az általuk a metanogén baktériumok számára előállított szubsztrát hasznosulását javítja.

A további biológiai kezelési eljárások alkalmazhatóságának szempontjából a kommunális és egyes ipari tevékenységekben keletkező iszapok esetében a fémionok jelenléte is meghatározó. A mikrohullámú energiaközlésnek az iszappelyhekre gyakorolt erőteljes dezintegráló hatása következtében az iszapvízben megjelenő réz ionok koncentrációja növekszik, ami például az anaerob fermentáció során a hidrogén képződését inhibiálja, 1́gy a gázképződés üteme csökken és a biogázkitermelési mutatók romlanak (Guo et al., 2008). 


\section{CÉLKITÜZÉS}

A doktori értekezésem célja a mikrohullámú energiaközlés hatásainak és alkalmazhatóságának vizsgálata egy, a szakirodalomban még nem teljesen feltárt területen, nevezetesen az élelmiszeripari iszapok esetében. A téma összetettsége, a gazdasági szempontból is jelentős, várható eredmények, a kutatómunka többirányú megközelítését tette szükségessé. Ennek megfelelően az alábbi rész-célkitüzésekkel éltem:

A mikrohullámú energiaközléses eljárás szervesanyag frakciókra gyakorolt hatásának vizsgálata, összehasonlítva a hagyományos termikus kezelések hatékonyságával.

A mikrohullámú energiaközléses eljárás hatékonyságának bizonyítása objektív paraméterek segítségével.

A mikrohullámú energiaközlésben meghatározó müveleti- és eljárás paraméterek, mint a kezelési idő, mikrohullámú teljesítmény-intenzitás, közölt energia, befolyásoló szerepének vizsgálata a szervesanyagok oldhatóságában és a biológiai lebonthatóság növekedésének folyamatában.

Az oldhatóság és a biológiai lebonthatóság mérésére szolgáló objektív mutatók kifejlesztése, amelyekkel az iszap mikrohullámú kezelési paraméterei objektíven vizsgálhatóvá tehetők, és amelyek alkalmasak a folyamat modellezésére és optimálására.

A mikrohullámú energiaközlés teljesítmény-intenzitástól és a közölt energia nagyságától függő hatásának vizsgálata az élelmiszeripari iszapok anaerob fermentációs folyamatára.

$>$ Összefüggések feltárása az iszapok szervesanyagtartalmában és biológiai lebonthatóságában bekövetkező változások és a dielektromos jellemzők között.

A mikrohullámú energiaközlési eljárás anaerob fermentációban történő előkezelésének gazdaságossági elemzése. 


\section{ANYAGOK ÉS MÓDSZEREK}

\subsection{A kísérletekhez felhasznált iszapok}

A kísérletekhez háromféle, különböző élelmiszeripari technológiákban keletkező szennyvízből származó iszapot használtam fel. A konzervipari szennyvíziszap kukoricakonzerv gyártásakor keletkező szennyvíz ülepítése, majd az iszap sűrítésekor keletkező, magas keményítőtartalmú iszap volt (DEKO-Food Zrt, Debrecen). A húsipari szennyvíziszap egy vágással és húsfeldolgozással foglalkozó üzem szennyvízének mechanikai szennyvíztisztítási fokozatából származó sürített iszap (PICK Zrt, Szeged). A tejipari szennyvíziszap egy tejüzem mechanikai szennyvíztisztítójából származó iszap (Sole-Mizo Zrt, Szeged). Az utóbbi két iszap esetében a rendelkezésre bocsátott minták víztelenítési eljárást követően kerültek gyüjtésre. A vizsgált iszap típusok esetében az üzemi- és a kommunális üzemi létesítmények szennyvize együttesen kezelt, az iszap tartalmazta a berendezések tisztításából és fertőtlenítéséből származó szennyvízben lévő vegyületeket is. A felhasznált szennyvíziszapok főbb jellemzőit a 2. táblázatban foglaltam össze.

2. táblázat. A vizsgálatokhoz használt iszapok jellemző paraméterei

\begin{tabular}{|l|c|c|c|c|}
\hline Iszap típusa & $\begin{array}{c}\text { TS } \\
{[\mathbf{m} / \mathbf{m} \%]}\end{array}$ & $\begin{array}{c}\mathbf{p H} \\
{[-]}\end{array}$ & $\begin{array}{c}\text { TCOD } \\
{\left[\mathbf{k g m}^{-3}\right]}\end{array}$ & $\begin{array}{c}\mathbf{B O D}_{\mathbf{5}} \\
{\left[\mathbf{k g m}^{-3}\right]}\end{array}$ \\
\hline Konzervipari & $5,2 \pm 0,9$ & $6,1 \pm 0,4$ & $136,2 \pm 4,1$ & $32,7 \pm 2,1$ \\
\hline Húsipari & $17,3 \pm 1,9$ & $6,2 \pm 0,3$ & $539,9 \pm 7,6$ & $31,4 \pm 2,1$ \\
\hline Tejipari & $24,8 \pm 1,3$ & $6,6 \pm 0,5$ & $398,5 \pm 9,2$ & $25,5 \pm 5,8$ \\
\hline
\end{tabular}

A mintákat a kezeléseket megelőzően fagyasztva tároltam $\left(-14^{\circ} \mathrm{C}\right)$ a levegőtől elzárt körülmények között PE tartályokban. A kezeléseket követően az analizálandó minták átmeneti tárolását hütve $\left(4^{\circ} \mathrm{C}\right)$ végeztem. 


\subsection{Mikrohullámú kezelések}

A mikrohullámú iszap kezeléseket a SZTE Mérnöki Kar Folyamatmérnöki Intézetében kifejlesztett mikrohullámú kezelő-mérőegységben végeztem. A berendezésbe a mikrohullámokat egy $2450 \mathrm{MHz}$ üzemi frekvencián müködő 700 Watt maximális teljesítménnyel rendelkező magnetron generálja. A magnetron fütőfeszültsége a nagyfeszültségü tápegység primer oldalán elhelyezett toroid transzformátor feszültség beállításával fokozatmentesen vezérelhető. A nagyfeszültségű tápegység vezérlése lehetővé teszi a folyamatos/szakaszos üzemmód választását, a szakaszosan sugárzó üzemmód esetén a sugárzási-sugárzásmentes időprogram másodperc pontossággal szabadon beállítható. A toroid transzformátor feszültségétől $\left(\mathrm{U}_{\mathrm{tr}}\right)$ függő magnetronteljesítményt $\left(\mathrm{P}_{\mathrm{m}}\right)$ előzetesen, teljesítményméréssel határoztam meg.

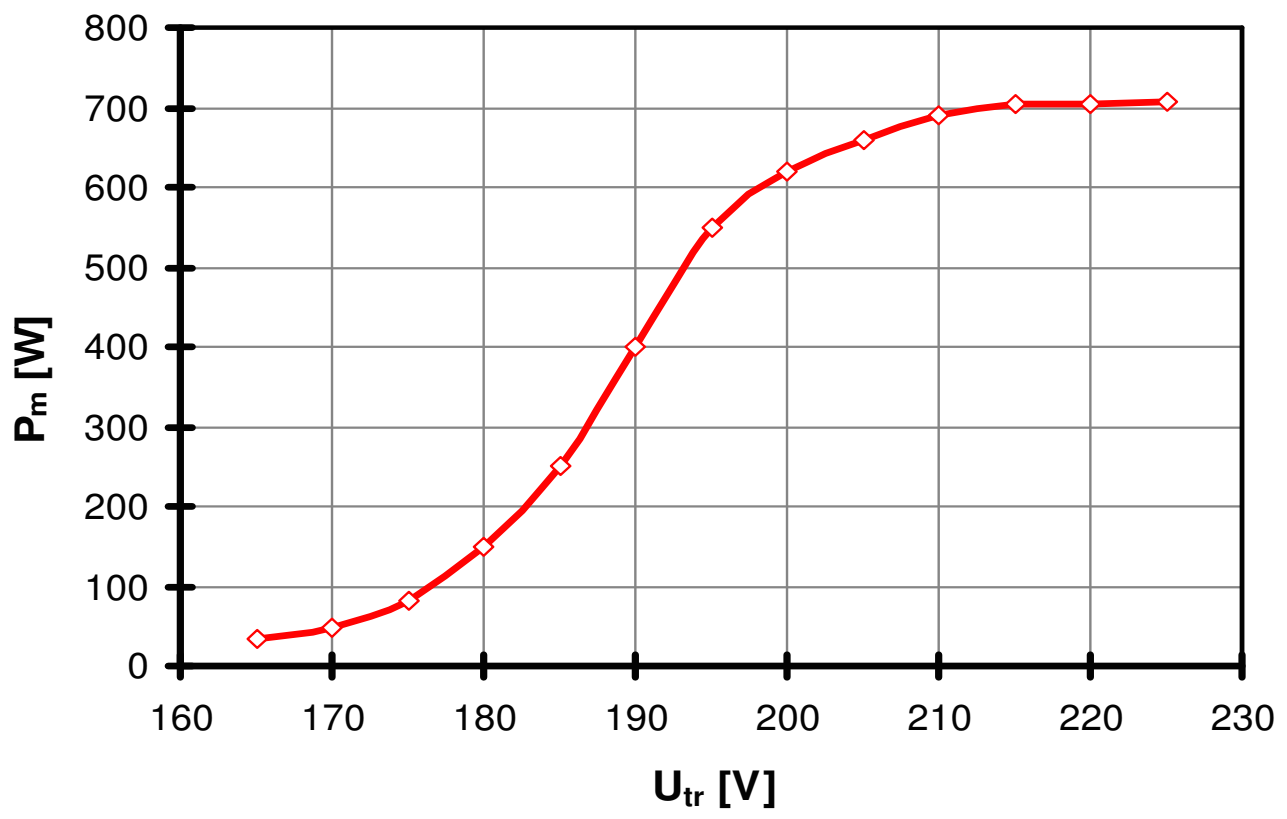

5. ábra. Magnetronteljesítmény kalibrációs görbéje

A magnetron által kibocsátott mikrohullámú energia a H10 hullámterjedést biztosító, négyszögletes csőtápvonalon, illetve a méretezett teflon illesztőéken keresztül jut be az alapmódusú (E010) hengeres üregrezonátor térbe. Ilyen hullámterjedés esetén az elektromos tér vektora párhuzamos a hengeres rezonátor szimmetriatengelyével, amely ebben az esetben már nem gerjeszti az üregrezonátoron az esetleges üzem közbeni nemkívánatos jelenségek megfigyelésére elhelyezett hosszanti vizsgálónyílásokat, továbbá a sugárzás környezetbe kijutását megakadályozó lezáró perforációt és hullámcsapdát. Az 
üreget lezáró lemez perforációjának átmérőjét, a sugárzás kijutásának megelőzése céljából, a frekvenciától függő szabadtéri hullámhossz értékének legfeljebb negyedének lehet megválasztani. A kiszámított $\lambda / 4(30,6 \mathrm{~mm})$ értéknél, a biztonságos müködést szem előtt tartva kisebb -12 mm - perforációjú elem került beépítésre. A berendezés négyszögletes tápvonalába helyezett $3 \mathrm{db}$ hangolórúd a tápvonal és az üregrezonátor illesztésére szolgálnak, segítségükkel a magnetronra visszajutó (reflektálódó) teljesítmény minimalizálható. Az illesztést minden mintatípus, illetve változtatott mintamennyiség esetén végrehajtottam.

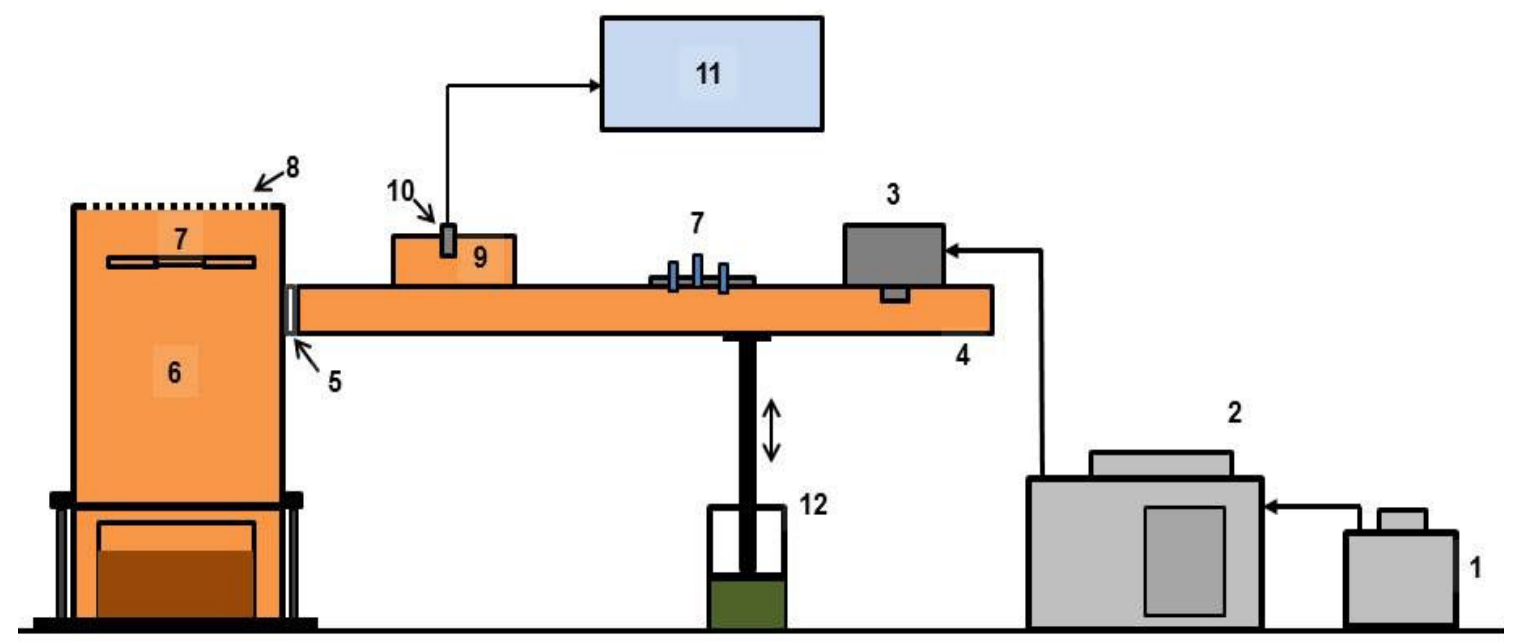

6. ábra. Mikrohullámú kezelőberendezés sematikus rajza

1-toroid transzformátor; 2-nagyfeszültségü táp vezérlöpanellel; 3-magnetron; 4- tápvonal; 5-illesztöék; 6-üregrezonátor; 7-hullámcsapda; 8-perforált lezárás; 9-iránycsatoló; 10-detektor; 11-teljesítménymérö;

12-hidraulikus emelö

A tápvonalba helyezett iránycsatoló, a kereszt alakú méretezett csatolórésen keresztül, az elektromágneses sugárzás a terjedési iránytól függően haladó irányú $\left(\mathrm{P}_{\mathrm{h}}\right)$, és visszavert irányú $\left(\mathrm{P}_{\mathrm{r}}\right)$ teljesítményeket csatol ki egy-egy csillapításon keresztül a berendezéshez csatlakoztatott NRVD típusú (Rohde\&Schwarz, Németország), kétcsatornás teljesíménymérőre.

A mikrohullámú iszap kezelési eljárás vizsgálata során a mikrohullámú teljesítményintenzitás (MWPL - microwave power level) és az anyaggal közölt fajlagos energia (IMWE-irradiated microwave energy) müveleti paraméterek hatását elemeztem. 


$$
\begin{aligned}
& \mathrm{MWPL}=\frac{\mathrm{P}_{\mathrm{m}}}{\mathrm{m}_{\text {iszap }}} \quad\left[\mathrm{Wg}^{-1}\right] \\
& \mathrm{IMWE}=\frac{\mathrm{P}_{\mathrm{m}} \times \tau \times \mathrm{I}}{100 \times \mathrm{m}_{\text {iszap }}} \quad\left[\mathrm{Jg}^{-1}\right]
\end{aligned}
$$

A két műveleti paramétert a magnetron teljesítmény $\left(\mathrm{P}_{\mathrm{m}}[\mathrm{W}]\right)$, a kezelt iszap tömege $\left(\mathrm{m}_{\text {iszap }}[\mathrm{g}]\right)$, a kezelési idő ( $\left.\tau[\mathrm{s}]\right)$ és a szakaszos üzemü kezelések során számított százalékos sugárzási idő (I [\%]) alapján határoztam meg.

\subsection{Dielektromos jellemzők meghatározása}

A dielektromos állandó ( $\varepsilon$ ') és a dielektromos veszteségi tényező ( $\varepsilon$ ") mérésére a SZTE Folyamatmérnöki Intézete számára fejleszette dielektrométer készüléket használtam. A berendezés mérőtápvonalához, NRVZ típusú szenzorokkal, kapcsolódó NRVD teljesítménymérő (Rohde\&Schwarz, Németország) segítségével a haladó irányú $\left(\mathrm{P}_{\mathrm{h}}\right)$ és a visszavert teljesítmény $\left(\mathrm{P}_{\mathrm{r}}\right)$ mérhető, amelyből [26] összefüggéssel a dielektromos állandó számítható.

$$
\mathcal{E}^{\prime}=\sqrt{\frac{\boldsymbol{P}_{r}}{\boldsymbol{P}_{h}}}
$$

Továbbá a mikrohullámú teret generáló 2450 MHz frekvenciájú magnetronból érkező sugárzás hullámkarakterisztikájának vizsgálatával - a $\lambda / 4$ távolságra elhelyezett detektorfejek villamos jeléből -fáziseltolás $(\phi)$ és a reflexió $(\Gamma)$ értékének felhasználásával a veszteségszög $(\delta)$ a [27] egyenlettel számítható, és ennek ismeretében a dielektromos veszteségi tényező értéke a [28] összefüggésből meghatározható.

$$
\begin{gathered}
\delta=\operatorname{arctg}\left(\frac{|\Gamma| \sin \varphi}{1-(|\Gamma| \cos \varphi)}\right)-\operatorname{arctg}\left(\frac{|\Gamma| \sin \varphi}{1+(|\Gamma| \cos \varphi)}\right) \\
\varepsilon^{\prime \prime}=\operatorname{tg} \delta \cdot \varepsilon^{\prime}
\end{gathered}
$$




\subsection{Vizsgálati és analitikai módszerek}

\subsubsection{Biokémiai oxigénigény mérése}

A biokémiai oxigénigény (BOI $\left[\mathrm{mgL}^{-1]}\right.$ ) a szerves anyagoknak a mikroorganizmusok által, aerob biológiai folyamatok során történő lebontása közben, meghatározott időtartam alatt, meghatározott hőmérsékleten elfogyasztott oxigén mennyiségét jelenti. A BOI koncentráció a minta biológiailag lebontható szervesanyag tartalmával arányos ún. nemspecifikus szervesanyag terhelési mutató.

A BOI több mérési módszer segítségével határozható meg. Az általam is használt respirometriás módszernél a mintát légmentesen zárt edényben mozgatják, kevertetik, és a baktériumok az anyagcsere-tevékenységük által elfogyasztott oxigént az edényben jelenlévő gázfázisból egészítik ki. A felszabaduló szén-dioxidot valamilyen abszorpciós szerrel (többnyire nátrium-hidroxiddal vagy kálium-hidroxiddal) a gázfázisból eltávolítják. Az oxigén fogyásának meghatározását legtöbbször állandó térfogaton, manometriás módszerrel a nyomás csökkenéséből számítják.

A vizsgálataim során a széntartalmú szerves anyagok mennyiségének meghatározására legtöbbször használt 5 napos biokémiai oxigénigényt $\left(\mathrm{BOI}_{5}\right)$ mértem egy hat férőhelyes, folyamatosan kevertetett rendszerü BOD Oxidirect (Lovibond) típusú respirometriás berendezéssel. A biológiai lebontás ütemét erősen befolyásoló hőmérséklet állandó értékének $\left(20 \pm 0,2^{\circ} \mathrm{C}\right)$ biztosítására a mérőrendszert termosztátszekrénybe (TS606, WTW) helyeztem. A BOI meghatározást az APHA 5210D (American Public Health Association, Approved Standard Methods, 2001) módszernek megfelelően végeztem. A minták hígítására és a meghatározás közben a pH fenntartására foszfát-puffer és nyomelem oldatok keverékét alkalmaztam.

A minták beoltására standardizált, szelektív, heterogén mikrobatörzseket tartalmazó BOD Seed (Cole-Parmer, USA) készítményt használtam. A poralakú készítményből szuszpenziót készítettem $50 \mathrm{ml}$ hígítóoldat felhasználásával, aktiváltam 60 perces folyamatos, intenzív keverés és levegőztetés mellett. A szilárd hordozóanyag eltávolítását 10 perces $600 \mathrm{~min}^{-1}$ fordulatszámon végzett centrifugálással végeztem. A beoltáshoz a felülúszó fázist használtam a minta térfogatára vonatkozóan 1\%-os koncentrációban. Az oltóiszap aktivitását glükóz-glutaminsavas módszerrel ellenőriztem. 
A BOI méréshez használt palackokba bemérendő minta térfogatát a készülék belső kalibrációjához tartozó mintatérfogatok és a várható BOI értékek függvényében választottam meg. A szénfázisban keletkező szén-dioxid megkötésére a zárószeptumon kialakított tartályba $\mathrm{KOH}$ pellet és $45 \mathrm{~m} / \mathrm{m} \%$-os $\mathrm{KOH}$ oldat keverékét helyeztem.

\subsubsection{Kémiai oxigénigény mérése}

A kémiai oxigénigény (KOI $\left.\left[\mathrm{mgL}^{-1}\right]\right)$ a mintában lévő szerves anyagok oxidálószerekkel, nedves úton végzett oxidációja során elfogyasztott oxigén mennyiségét adja meg. Az iszapok magas szervesanyag tartalma miatt a meghatározáshoz a bikromátos oxidáción alapuló mérési eljárást választottam. A kálium-bikromát savas közegben, magas hőmérsékleten a következőképpen reagál:

$$
\mathrm{K}_{2} \mathrm{Cr}_{2} \mathrm{O}_{7}+4 \mathrm{H}_{2} \mathrm{SO}_{4}=\mathrm{K}_{2} \mathrm{SO}_{4}+\mathrm{Cr}_{2}\left(\mathrm{SO}_{4}\right)_{3}+4 \mathrm{H}_{2} \mathrm{O}+3 \mathrm{O}
$$

A keletkező oxigén a szerves anyagokat oxidálja. Az általam használt HACH küvettás gyorstesztek mérési metódusa megfelel az USEPA5520D KOI mérési módszernek. A tesztcsövek a meghatározási módszernek megfelelően kálium-bikromátot és kénsavat, továbbá ezüst katalizátort és a klór tartalmú komponensek kicsapására szolgáló higanyszulfátot tartalmaznak. A minták roncsolását termikus roncsolóban (ET 108, Lovibond) végeztem $150^{\circ} \mathrm{C}$-on 2 óráig. A termikus-savas roncsolás során keletkező $\mathrm{Cr}^{3+}$ ionok okozta színváltozást fotometriásan mértem PC Checkit fotométerrel (Lovibond).

A szervesanyag tartalommal arányos KOI mérés során meghatároztam a teljes szervesanyag tartalmat (TCOD-total chemycal oxygen demand) valamint a vízoldható szervesanyag tartalommal arányos KOI értéket (SCOD-soluble chemycal oxygen demand). A TCOD mérésnél az analizált minta a teljes iszapmátrixot tartalmazta. A SCOD mérésénél először az iszap vízoldható fázisát kellett elválasztani. A szeparálást 15 perces centrifugálással (MPW-350, Lengyelország) 32000×g RCF értékkel végeztem. A centrifugálással kapott felülúszót $0,45 \mu \mathrm{m}$ (Millipore) pórusméretü cellulóz-acetát alapanyagú mikroszürőt alkalmazva fecskendőszürővel tovább szürtem. A vizsgált minta TCOD és SCOD értékeinek különbsége megadja a nem oldható (partikuláris) formában lévő szervesanyagok koncentrációját (PCOD).

$$
\mathrm{TCOD}=\mathrm{PCOD}+\mathrm{SCOD}
$$




\subsubsection{Szárazanyag tartalom és összes illékony szilárd anyag}

A szárazanyag tartalom (TS) meghatározását az iszapok esetén elfogadott APHA ASTM2540B metódusnak megfelelően szárítószekrényben történő, állandósult tömegig történő szárítási módszerrel végeztem $103^{\circ} \mathrm{C}$ hőmérsékleten, homogenizált mintából.

Az összes illékony szilárd anyagok (VS) koncentrációját az előzőekben leírtaknak megfelelően szárított iszapminták $550^{\circ} \mathrm{C}$-on, izzítókemencében (Nabertherm LE 2-11, Németország) történő 60 perces izzítása utáni tömegcsökkenésből határoztam meg, az APHA 2540E módszernek megfelelően.

\subsubsection{Anaerob rothasztási tesztek}

A szennyvíziszapok anaerob körülmények közötti biológiai lebonthatóságát mezofil hőmérséklettartományú rothasztási tesztekkel határoztam meg. A szennyvíziszapok biogáz hozamának mérésére a WTW OxiTop-C 110 típusú 12 féröhelyes, folyamatosan kevertetett, anaerob, manometrikus mérőrendszert használtam. A légmentesen zárható 250 $\mathrm{cm}^{3}$ hasznos térfogatú reaktorokhoz tartozó méröfejek 2 órás időközönként rögzítették a palackban mérhető nyomást. A mérési adatokat az adatgyüjtő egység a mérőfejekbe épített infravörös távadó egységből hívta le, és a készülék saját szoftvere segítségével a nyomásdiagramok megjeleníthetők, illetve MS Excel kompatibilis formátumba konvertálhatóak. A mérőfejek által a reaktorban mért és rögzített nyomásértékekből ( $\mathrm{p}_{\mathrm{r}}$ $[\mathrm{Pa}])$, a minta fölött lévő gáztér térfogatának $\left(\mathrm{V}_{\mathrm{r}}\left[\mathrm{m}^{3}\right]\right)$ és a fermentációs hőmérséklet $\left(\mathrm{T}_{\mathrm{f}}\right.$ [K]) ismeretében az egyetemes gáztörvényt felhasználva számítottam ki a keletkező biogáz térfogatát $\left(\mathrm{V}_{\mathrm{bg}}\left[\mathrm{m}^{3}\right]\right)$ szobahőmérsékletre $\left(\mathrm{T}_{\text {norm }}[\mathrm{K}]\right)$ és atmoszférikus nyomásra $\left(\mathrm{p}_{\mathrm{atm}}[\mathrm{Pa}]\right)$ normálva:

$$
V_{b g}=\frac{p_{r} \cdot V_{r}}{p_{a t m}} \frac{T_{n o r m}}{T_{f}} \quad\left[\mathrm{Nm}^{3}\right]
$$

A fermentációt $35 \pm 0,5^{\circ} \mathrm{C}$ hőmérsékleten végeztem, amely állandóságának biztosítására a kísérleti rendszert termosztátszekrénybe helyeztem. Az iszapminták beoltására egy kommunális szennyvíztisztító telep mezofil rothasztójának iszapját használtam. A beoltás előtt az oltóiszapot adaptáltam a vizsgált iszapokhoz. Az adaptálást a későbbi anaerob lebontási folyamatok során biztosított hőmérsékleten végeztem, az oltóiszap: 
szennyvíziszap térfogati arányát az előzetes mezofil rothasztási tesztek eredményei alapján 3:1 értéknek választva. A vizsgált iszapok esetleges eltérő összetétele miatt minden rothasztási teszt előtt az iszap szuszpenziók pH-ját 7,2 értékre állítottam be, az oltóiszap adagolási koncentrációját 10\%-nak állítottam be.

A biogáz összetételének vizsgálata céljából az azonos módon előkezelt iszapból párhuzamos mintákat alkalmazva az egyik reaktorban a megfelelően kialakított zárószeptum tartályába $\mathrm{KOH}$ pellet és túltelített $\mathrm{KOH}$ oldat keverékével (összes térfogat 6 $\mathrm{mL}$ ) a képződő szén-dioxidot megkötöttem, amelyből a biogázban lévő $\mathrm{CO}_{2}$ komponens aránya becsülhetővé vált. Az elegendő biogázproduktummal rendelkező minták esetében a biogáz összetételét Airtox infravörös detektorral rendelkező hordozható gázanalizátorral (Fresenius Gmbh, Németország) is vizsgáltam.

\subsubsection{Mikrobiológiai vizsgálatok}

Az iszapminták összes élőcsíraszámát IME 2032 Autoanalyzer (Cole\&Parmer, USA) készülékkel mértem, az iszapminták desztillált vízzel való hígítása és centrifugálás után. A csíraszám meghatározásra használt IME TM tesztcsöveket a steril edényzetben történő mintaelőkészítés után kapott felülúszóba törve, a csőben lévő vákuum a minát felszívta, majd 60 másodperces keverés és homogenizálás után (Vortex) a csöveket zártam és az inkubálóegységbe helyeztem $35^{\circ} \mathrm{C}$ hőmérsékletre.

A tesztcsövekben lévő trifenil-tetrazolium klorid (TTC) reagens a mintában található élő sejtek oxidációs folyamatai következtében színváltozáson megy keresztül, amely alapján az összes élő mikroorganizmus száma meghatározható (USPTO 5550032 számú szabadalom). Az abszorbancia változás mértékéből, illetve az inkubációs idő hosszából a fotometriás elven működő analizátor egység, a belső kalibrációja alapján számítja a csíraszámot (CFU/mL). 


\section{EREDMÉNYEK ÉS ÉRTÉKELÉSÜK}

\subsection{A vízoldható szervesanyagfrakció változásai}

Az iszap kezelési eljárások hatékonyságának jellemzésére a szakirodalomban az egyik legtöbbet használt módszer az iszapot alkotó szervesanyagok vízoldhatóságában bekövetkező változások mérése. A víz- és szennyvízkezelésben használt standardizált mérési módszerek közül a kémiai oxigénigény (KOI, COD) mérésre visszavezethető mutatók alapján az egyes kezelések hatékonysága számszerüsíthető és összehasonlítható. A mérési metódust az iszap hígítását követően a vízoldható frakció frakcionálásással nyert mintán elvégezve (SCOD) a szervesanyagok százalékos aránya megadhatóvá válik a teljes szervesanyaghoz viszonyítva.

\subsubsection{Termikus iszapkezelési módszerek összehasonlító vizsgálata}

A szakirodalmi forrásokat áttekintve megállapítható, hogy az élelmiszeripari eredetű nyers iszapokra vonatkozóan nem állnak rendelkezésre kutatási eredmények, ezért a saját kísérleti munkám tervezése során a kommunális iszapokhoz hasonló változási tendenciákat feltételeztem. Mivel a kísérleteim során kizárólag a mikrohullámú energiaközlés önálló hatását kívántam vizsgálni, így az előzetes kísérleti beállítások során összehasonlító módszerként a hagyományos termikus $(\mathrm{CH})$ kezelést választottam három különböző hőntartási hőmérsékleten $\left(80^{\circ} \mathrm{C}: \mathrm{CH}-80 ; 90^{\circ} \mathrm{C}\right.$ : $\mathrm{CH}-90 ; 95^{\circ} \mathrm{C}$ : $\left.\mathrm{CH}-95\right)$, minden esetben 60 perc hőntartási időtartamig. Az eddigi kutatási eredményekre és tapasztalatokra támaszkodva, a szakirodalomban leírt kísérleti körülmények és beállítások figyelembevételével, kiszámítottam az azoknak megfelelő fajlagos kezelési teljesítményintenzitást. Mivel ezek jelentős eltéréseket mutattak, illetve ezen paraméter változásának hatásait ugyanazon alapanyag és/vagy kísérletsorozat során nem vizsgálták, az előkísérleteimnél a fajlagos kezelési intenzitást három, általam kiválasztott értékre állítottam be $\left(0,5 ; 2 ;\right.$ ill.5 $\left.\mathrm{Wg}^{-1}\right)$.

A kétféle - tejipari és húsipari - eredetű szennyvíziszap esetében a kezdeti vízoldhatóság mértékében jelentős különbségek mutatkoztak. Az élelmiszeripari szennyvíz és iszap a magas szervesanyagtartalma ellenére alacsony hatásfokú biológiai hasznosíthatóságát a szakirodalomban már leírták (Bohdziewicz and Sroka, 2006), amely részben a lebontó 
mikroorganizmusok számára könnyen hasznosítható, oldott formában lévő komponensek alacsony részarányára vezethető vissza.

A saját kísérleteimhez felhasznált kezeletlen tejipari iszap szervesanyagainak vízoldhatósága lényegesen alacsonyabb (kb. 9,5\%) a húsipari iszaphoz viszonyítva (kb. 29\%), amely a tejipari szennyvíznek a húsipari szennyvíztől eltérő összetételére (savófehérjék, a hőkezelés és alvasztás hatására részlegesen koagulálódott fehérjefrakciók), és a magasabb ion, detergens és fertőtlenítőszer koncentrációra vezethető vissza. Az atmoszferikus nyomáson végzett termikus kezelések közül a legmagasabb hőmérsékletü $\left(95^{\circ} \mathrm{C}\right) 60$ perces kezeléssel a tejipari iszap vízoldhatóságának mértéke $67 \%$-al növekedett, amely százalékos növekmény jelentősnek tekinthető, azonban az oldhatóság a szervesanyagfrakción belül még így sem éri el a 16\%-ot.

A mikrohullámú kezelések esetében a növekmény minden beállítás esetében magasabb volt, mint a termikus eljárásnál, a $2 \mathrm{Wg}^{-1}$ fajlagos intenzitás melletti 25 perces, illetve az $5 \mathrm{Wg}^{-1}$ fajlagos teljesítmény-intenzitású rövid idejü -5 perces- kezelést követően a KOI egységben mért vízoldható formában lévő összetevők aránya 30\% fölé növekedett a teljes szervesanyag frakción belül (7. ábra).

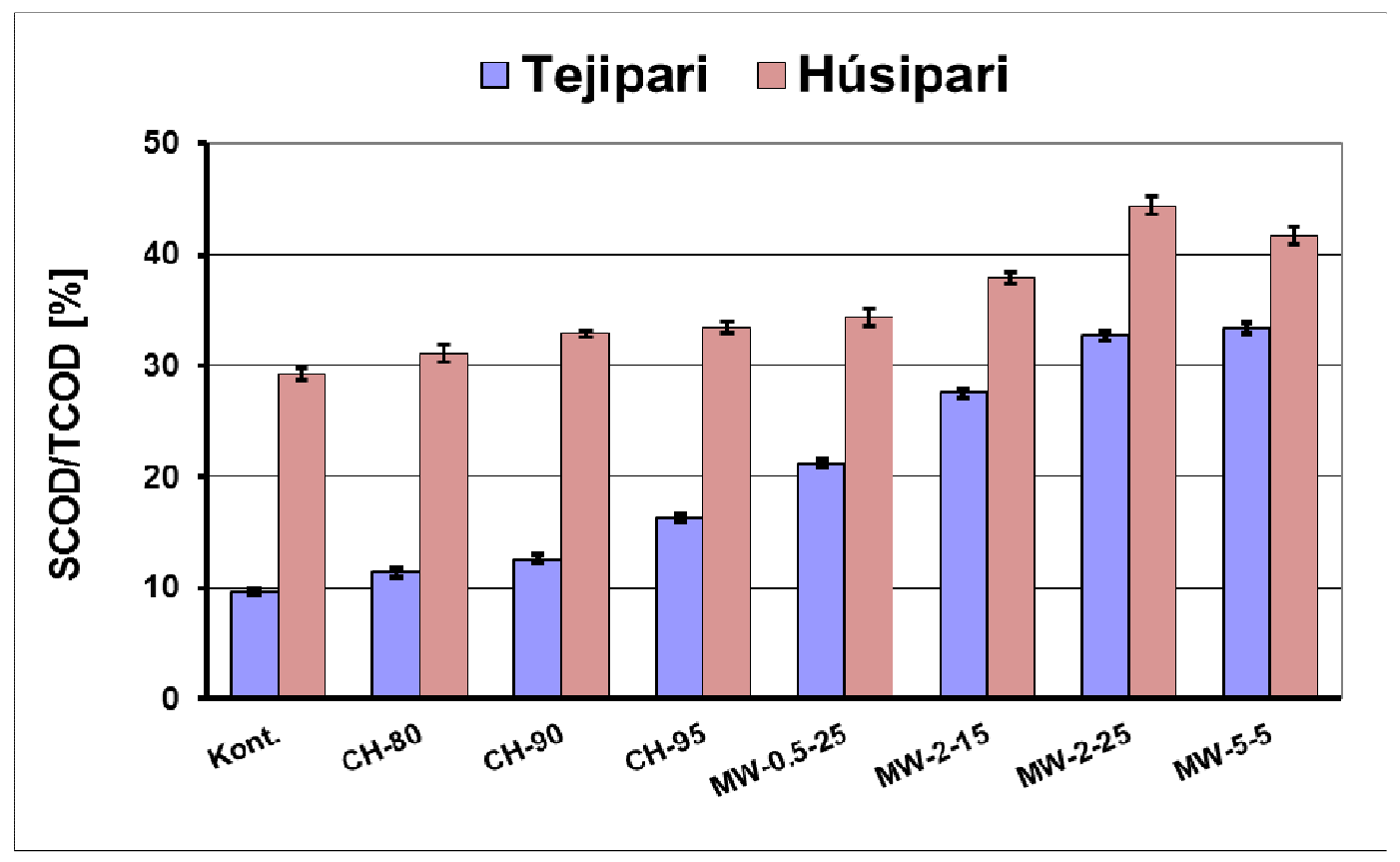

7. ábra. A szervesanyag-vízoldhatóság változása különböző kezeléseket követően 
A húsipari iszap esetében a kontrollminta kezdeti magas szervesanyag-oldhatósága a termikus kezelés hatására kismértékben növekedett, a kezelési hőmérséklet $90^{\circ} \mathrm{C}$-ról $95^{\circ} \mathrm{C}$ ra növelése a szórásterjedelmet figyelembe véve további szignifikáns változást azonban már nem eredményezett. Az előzetes kísérleti beállítások közül $2 \mathrm{Wg}^{-1}$ fajlagos teljesítményintenzitást alkalmazva, 25 perces kezelést (kódolás: MW-2-25) követően a vízoldhatóság abszolút értéke a tejipari iszaphoz képest magasabb volt, azonban a növekmény mértéke (kb. 51\%) a tejipari iszapéhoz képest (kb. 250\%) kisebbnek bizonyult. A húsipari eredetü iszapok esetében összességében tehát megállapítható, hogy a tejipari iszaphoz hasonlóan, a mikrohullámú kezelések a hagyományos termikus kezelésekhez képest nagyobb mértékben növelik a szervesanyagok vízoldhatóságát, azonban a mikrohullámú eljárás következtében, a kezeletlen iszaphoz viszonyított növekmény mértéke a húsipari iszapok magasabb kezdeti szervesanyag tartalmának ellenére - az alacsonyabb detergens és ionkoncentráció miatt - a tejipari iszaphoz képest alacsonyabb.

A kezelések hatására az SCOD/TCOD paraméter értékének százalékos növekményét az egyes tanulmányokban szereplő, 10-60\%-os nagyságrendbe eső, növekményekkel (Appels et al., 2010; Climent et al., 2007; Park et al., 2010) összevetve magasnak tünhet. Azonban figyelembe kell venni, hogy a primer és a kémiai tisztítási eljárásokból származó élelmiszeripari iszapok a kommunális, valamint a biológiai tisztítási eljárásból származó iszapoknál lényegesen alacsonyabb kezdeti oldhatósággal, kompaktabb iszappehely szerkezettel rendelkeznek, így az egyes kezelések hatására bekövetkező változások arányai nagyobbak.

$\mathrm{Az}$ élelmiszeripari iszapok esetében elért eredményeim a kommunális iszapok mikrohullámú kezelésének hatását vizsgáló más, nagyobb teljesítmény-intenzitást alkalmazó vizsgálatokról beszámoló, közleményekben leírt eredményekkel (pl.: Eskicioglu et al., 2006) egyező tendenciát mutatnak.

Az ismétlésekkel végzett különböző termikus kezelésekkel nyert minták vízoldható szervesanyag tartalom mérési eredményeire vonatkozóan $\chi^{2}$ próbát alkalmazva homogenitásvizsgálati módszer segítségével vizsgáltam, hogy az alkalmazott kezelés hatására bekövetkező koncentrációnövekedés szignifikánsnak (ha $\chi^{2}>\chi^{2}$ krit) tekinthetö-e tejipari (3. táblázat) és a húsipari iszap (4. táblázat) esetében. 
3. táblázat. Tejipari iszap kezelések vízoldhatóságra gyakorolt hatásának vizsgálata $\chi 2$ próbával

\begin{tabular}{|l|c|c|c|c|c|c|c|}
\hline \multicolumn{7}{|c|}{ Tejipari iszap kezelések $\chi$ 2 próba eredményei } \\
\hline & CH-80 & CH-90 & CH-95 & MW-0.5-25 & MW-2-15 & MW-2-25 & MW-5-5 \\
\hline Kont. & 14,24 & 137,89 & 105,92 & 129,38 & 89,68 & 176,56 & 112,79 \\
\hline CH-80 & - & 74,14 & 57,30 & 121,03 & 93,47 & 148,19 & 77,57 \\
\hline CH-90 & - & - & $\mathbf{7 , 4 1}$ & 85,75 & 113,62 & 60,66 & 41,07 \\
\hline CH-95 & - & - & - & 66,63 & 81,51 & 78,28 & 20,83 \\
\hline MW-0.5-25 & - & - & - & - & 14,21 & 81,64 & 34,50 \\
\hline MW-2-15 & - & - & - & - & - & 131,30 & 34,41 \\
\hline MW-2-25 & - & - & - & - & - & - & 105,34 \\
\hline
\end{tabular}

$\chi 2_{\text {krit }}=7,78 ; D F=4 ; p<0,05$

4. táblázat. Húsipari iszap kezelések vízoldhatóságra gyakorolt hatásának vizsgálata $\chi 2$ próbával

\section{Húsipari iszap kezelések $\chi 2$ próba eredményei}

\begin{tabular}{|l|c|c|c|c|c|c|c|}
\hline & CH-80 & CH-90 & CH-95 & MW-0.5-25 & MW-2-15 & MW-2-25 & MW-5-5 \\
\hline Kont. & 42,19 & 70,00 & 69,49 & 48,98 & 69,28 & 77,93 & 50,97 \\
\hline CH-80 & - & 12,88 & 52,50 & 38,49 & 50,88 & 44,36 & 15,61 \\
\hline CH-90 & - & - & 33,62 & 55,13 & 62,23 & 23,10 & 26,70 \\
\hline CH-95 & - & - & - & 43,82 & 126,07 & 31,06 & 96,80 \\
\hline MW-0.5-25 & - & - & - & - & 67,84 & 38,37 & 72,14 \\
\hline MW-2-15 & - & - & - & - & - & 51,52 & 21,80 \\
\hline MW-2-25 & - & - & - & - & - & - & 53,20 \\
\hline
\end{tabular}

$\chi 2_{\text {krit }}=7,78 ; D F=4 ; p<0,05$

A 3. illetve 4. táblázatban szereplő SCOD koncentrációkból számított $\chi^{2}$ értékeket tekintve megállapítható, hogy a vízoldható szervesanyagok mennyisége valamennyi kísérleti kezelési beállítás esetében, a kezeletlen mintához képest mindkét vizsgált élelmiszeripari eredetű iszap esetében szignifikánsan nagyobb. A különböző iszapkezelési módszerek összehasonlításakor megállapítható, hogy tejipari iszap esetében a hagyományos termikus kezelésnél a hőmérséklet $90^{\circ} \mathrm{C}$-ról $95^{\circ} \mathrm{C}$-ra növelésének hatása nem szignifikáns $\left(\chi^{2}<\chi_{\text {krit }}^{2}\right)$. 
A mikrohullámú kezelések a hagyományos termikus eljárásokhoz képest szignifikánsan nagyobb szervesanyag-oldhatósági növekmény elérését tette lehetővé mindkét iszaptípus esetében, $10 \%$ hibavalószínűséget feltételezve. Mindezek alapján a mikrohullámú sugárzás, annak teljesítmény-intenzitásától és a behatási időtől függő mértékben, a termikus kezeléstől jobb hatásfokkal alkalmazható, elsősorban az eredetileg komplexebb struktúrával rendelkező iszapoknál.

\section{T1a: Élelmiszeripari iszapok esetében az atmoszferikus nyomáson végzett mikrohullámú kezelés az atmoszferikus nyomáson kivitelezett, hagyományos termikus kezelésekhez képest rövidebb müveleti idöszüikséglet mellett nagyobb mértékben növeli a szervesanyagok oldhatóságát.}

\subsubsection{Mikrohullámú műveleti paraméterek és a szervesanyag oldhatóság összefüggése}

Az előzetes kísérletek során megállapítottam, hogy a mikrohullámú iszapkezelés a hagyományos termikus eljárásokhoz képest jobb hatásfokkal és rövidebb müveleti időszükséglettel alkalmas a vizsgált élelmiszeripari eredetű szennyvíziszapokban lévő szervesanyagok oldhatóságának növelésére. Ezen okból, a további vizsgálatok során a mikrohullámú kezelés fajlagos teljesítmény-intenzitásának hatását elemeztem. A kísérletek során öt teljesítményszint $\left(0,5 ; 1,5 ; 2,5 ; 3,5 ; 5 \quad \mathrm{Wg}^{-1}\right)$ és öt különböző kezelési idő (10;20;30;40;50 perc) beállítása mellett kezeltem mindkét iszapot háromszori ismétlés alkalmazásával.

A kétféle iszap jelentősen eltérő kezdeti szervesanyag oldhatóságának ellenére, a fajlagos mikrohullámú teljesítmény-intenzitás és a kezelési idő paraméterek hatását tekintve azonos tendencia állapítható meg. Alacsony fajlagos kezelési teljesítmény alkalmazásakor a kezelési idő nagyobb mértékben befolyásolja az oldhatóság változását, a nagyobb kezelési teljesítmény-intenzitásnál a kezelési idő egy - teljesítmény-intenzitástól függő - határon túli növelése nem okoz további növekedést az SCOD/TCOD paraméter értékében (7. ábra). 
A tejipari iszapnál a legnagyobb alkalmazott $5 \mathrm{~W} / \mathrm{g}$ teljesítmény-intenzitás esetén a kezelési időnek 30 percről 40 percre növelése a mérési eredmények szórásának kétmintás F-próbával igazolt egyezőségének teljesülése miatt $\left(\mathrm{F}=0,0224 ; \mathrm{F}_{\text {krit }}=0,0526\right.$; vagyis $\mathrm{s}_{1}=\mathrm{s}_{2}$; $\alpha=0.05)$ alkalmazható kétmintás t-próbával vizsgálva már nem tekinthető szignifikánsnak $\left(\mathrm{t}=2,219 ; \mathrm{t}_{\mathrm{krit}}=2,776\right)$ 95\%-os megbízhatósági szinten. A 3,5 W/g fajlagos teljesítményintenzitás esetén sincs szignifikáns hatása a kezelési idő 30 percet meghaladó alkalmazásának ( $\left.\mathrm{t}=1,959 ; \mathrm{t}_{\mathrm{krit}}=2,776\right)$. A 3,5 W/g-nál alacsonyabb fajlagos mikrohullámú teljesítmény tartományban a kezelési idő növelés hatása szignifikánsnak tekinthető.

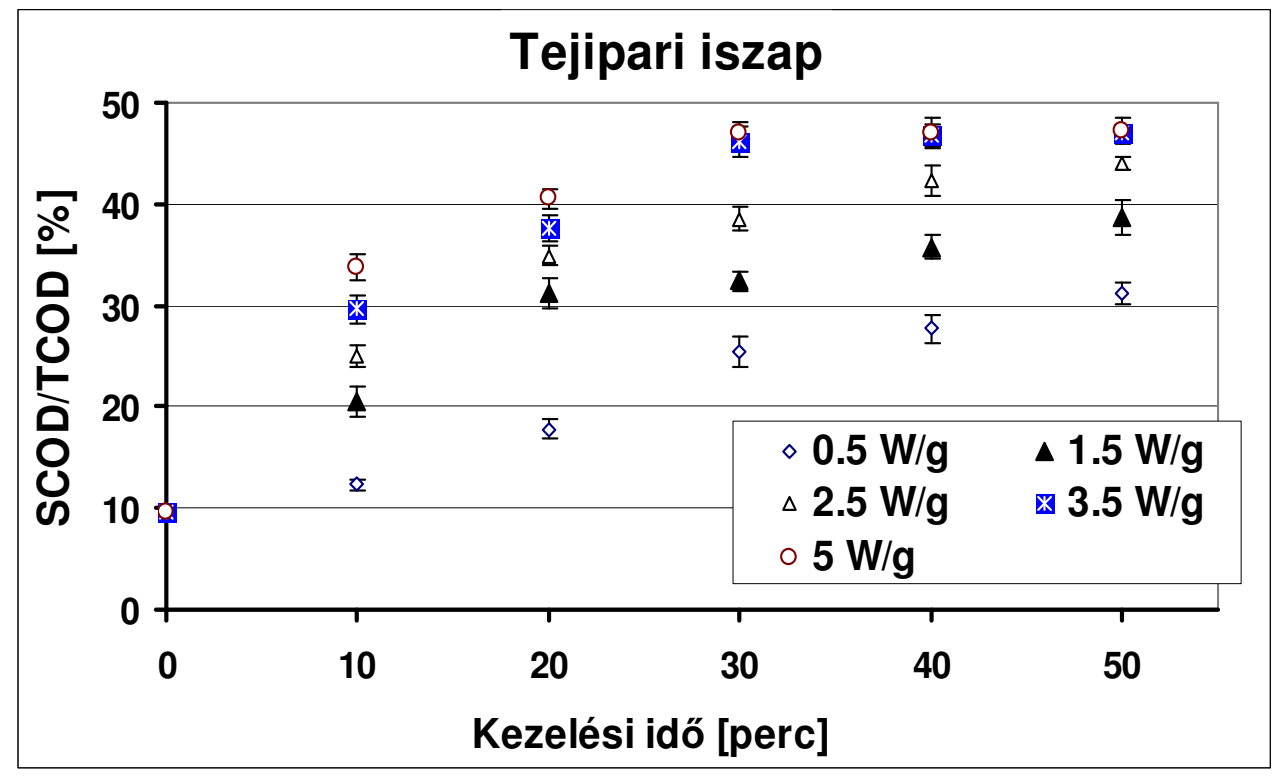

8. ábra. A százalékos szervesanyag vízoldhatóság tejipari iszap mikrohullámú kezelését követően

A húsipari eredetű iszapnál a szervesanyagok vízoldhatóságában bekövetkező növekedés mértékét a 2,5-5 W/g teljesítmény-intenzitás tartományban a kezelési idő kevésbé befolyásolja, mint a tejipari iszap esetében tapasztaltam (9. ábra). A 3,5 és $5 \mathrm{~W} / \mathrm{g}$ kezeléseket követően a szervesanyag vízoldhatóság mértékében 20 perces időtartam után szignifikáns növekedés nem volt kimutatható. A nagyobb szervesanyagtartalommal, és ezen belül a magasabb oldható szervesanyag hányaddal rendelkező húsipari iszap oldhatóság változása szempontjából a magasabb teljesítmény-intenzitás (MWPL) alkalmazása csak abban az esetben indokolt, amennyiben a kezelési időszükségletet csökkenteni (vagyis a kezelési kapacitást növelni) szükséges. 


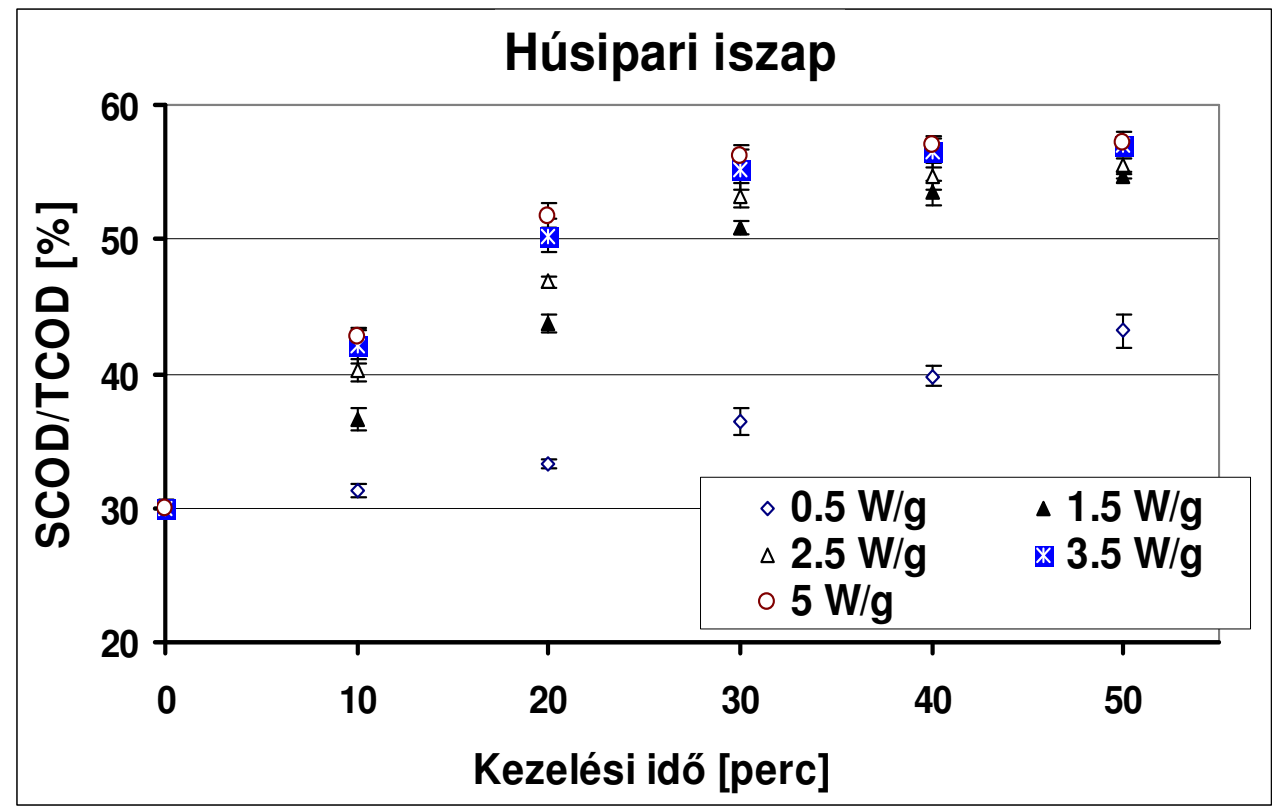

9. ábra. A százalékos szervesanyag vízoldhatóság húsipari iszap mikrohullámú kezelését követően

A kémiai oxigénigény paraméterrel jellemzett szervesanyag vízoldhatóságában végbement változások az iszapok szerkezeti dezintegrálódásával összefüggésben vannak, és ez az iszapok későbbi kezelési lehetőségeit - víztelenítés, biológiai stabilizálási eljárások befolyásolja (Eskcoiglu et al., 2008). A részletesebb anyagszerkezeti és analitikai vizsgálatok a szervesanyag frakción belül az egyes komponensek oldhatósági változásai tekintetében sokszor ellentmondó eredményeket közölnek.

A szénhidrát és fehérje komponensek változásai alapján sem azok mértékének, sem azok dinamikájának tekintetében egyértelmü és egybehangzó megállapítások nem tehetőek: Appels et al. (2013) például a szénhidrát frakciók oldhatóságának kb. 30\%-os növekedését figyelte meg, míg Yu et al. (2009) annak megkétszereződését. Mivel azonban az egyes komponesek elkülönített mennységi meghatározására, illetve az egyes vegyületek szerkezeti változásainak vizsgálatára nem volt lehetőségem, így a változásokat összegparaméterek mérésére visszavazetve jellemeztem. 
A sürített, illetve víztelenített, biológiai eredetű iszapokra jellemző polimer-mátrix szerkezet bomlása, továbbá az intenzív hőfejlődés következtében felszakadó sejtfalak miatt kiáramló intracelluláris komponensek következtében az intercelluláris térben a lebegőanyagok és kolloid mérettartományú vegyületek koncentrációja növekszik. A koncentrációnövekedés az indirekt módszernek tekinthető nefelometriás zavarosságméréssel nyomon követhető volt.

A SCOD/TCOD arányhoz hasonló tendenciával írható le a kezeléseket követően hígított minták szeparálása után nyert felülúszó fázis nefelometriás zavarosság egység (NTU) értékeinek változása is (10. ábra). A tejipari iszap esetében a legnagyobb teljesítmény-intenzitás alkalmazása során a 30 perces kezelést követően tapasztalt NTU csökkenés feltehetőleg a vizes fázisba került egyes szerves vegyületek hőhatásra bekövetkező részleges koagulálódásával, illetve a fehérje és szénhidrát frakciók részleges hidrolízisét követő polimerizációs jelenségekkel magyarázható (Eskiciouglu et al., 2007), amelyre a KOI mérés kevésbé érzékeny, mint az optikai módszer.

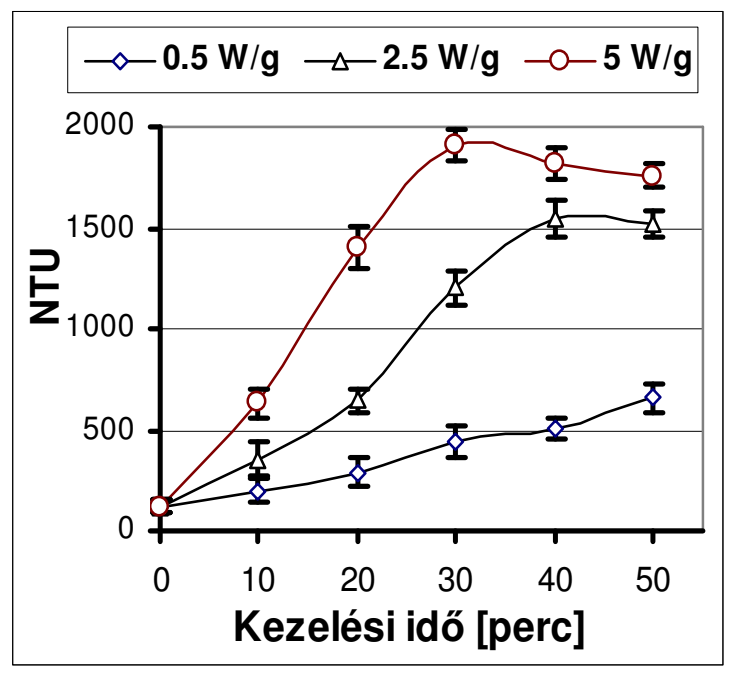

a)

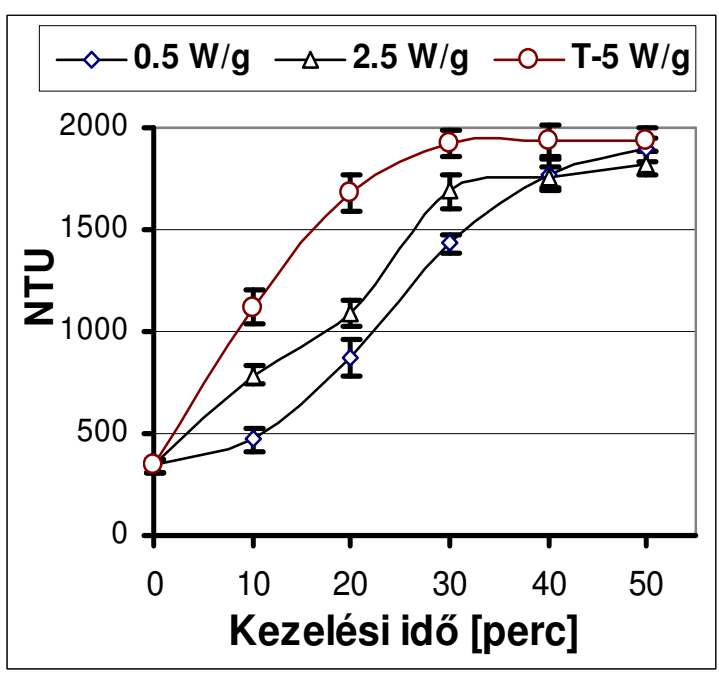

b)

10. ábra. Az iszapminták vizes szuszpenziójában mérhető zavarosság a) tejipari és b) húsipari iszap esetében

Meg kell jegyezni azonban, hogy az iszapok esetében, a magas szárazanyagtartalom miatt, a zavarosságmérést 150-szeres hígítást követően lehet elvégezni, amely az iszapmosási eljárásokhoz hasonlóan a szervesanyag tartalom oldhatóságát befolyásolja, így a zavarosságmérés az általam is alkalmazott formában, önmagában nem alkalmas a 
mikrohullámú kezelések hatására az anyagban végbemenő változások objektív, kvantitatív jellemzésére, ezért csak kiegészítő információkat nyújthat.

Az iszap szerkezetében végbemenő változások az iszap reológiai paramétereivel is jellemezhetőek. A termikus kezelések során először az iszappelyhek stabilitását biztosító extracelluláris polimerháló hidrolízise megy végbe, majd egy kritikus hőmérséklet, illetve ennek megfelelően egy meghatározott hőterhelés elérése után a sejtfalak felszakadásával a sejten belüli állomány kiszabadul (Cho et al., 2012). Az első lépcsőben lejátszódó iszapszerkezeti módosulást a viszkozitás csökkenése; majd a sejtnedv kiszabadulását, és ezáltal a vizes fázisban lévő szervesanyagok koncentrációjának növekedését a viszkozitás kismértékű növekedése kíséri.

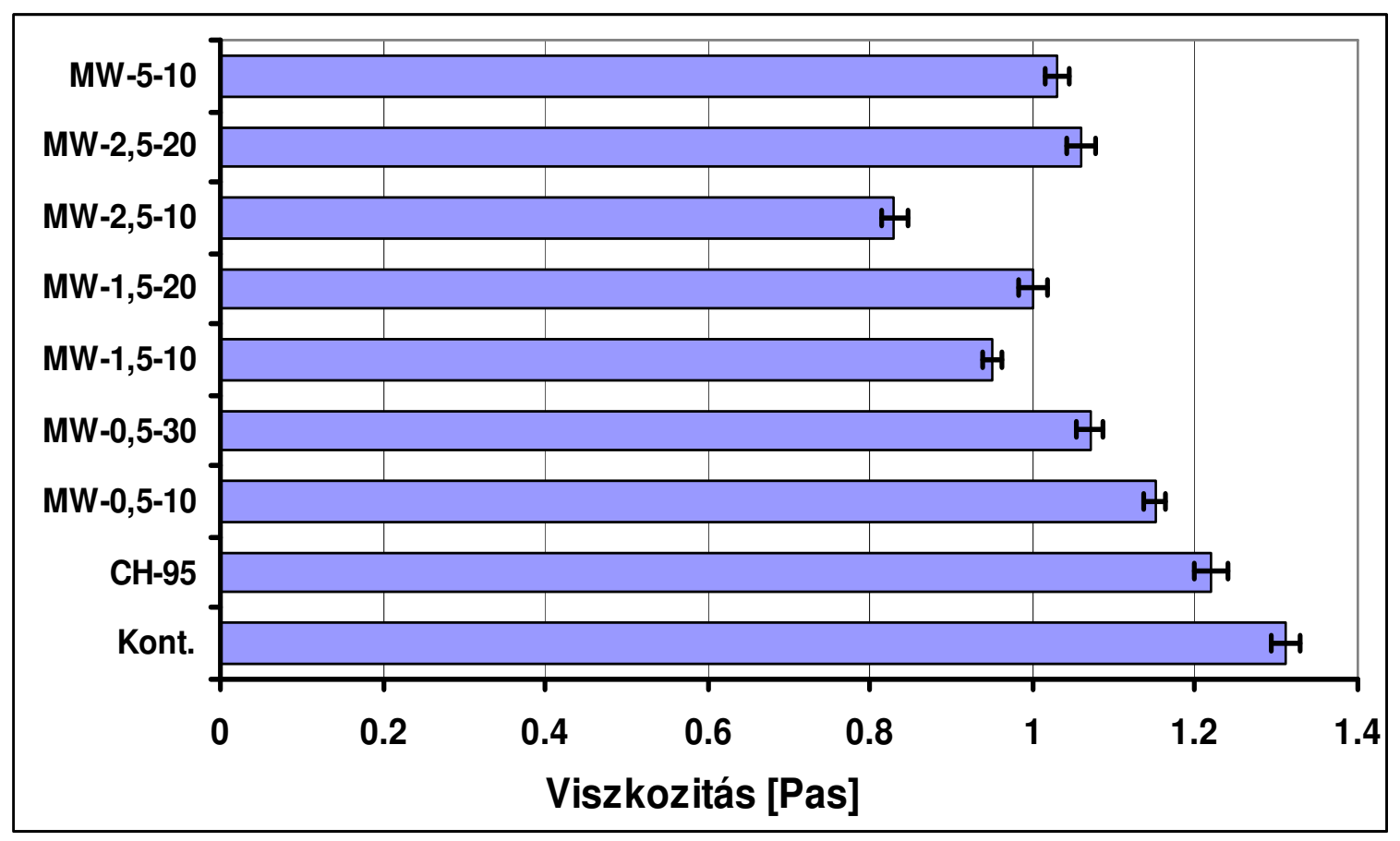

11. ábra. Viszkozitás tejipari iszap esetében $\left(\mathrm{t}=55^{\circ} \mathrm{C}\right)$

A tejipari iszap kezelését követően az azonos hőmérsékletre $\left(55^{\circ} \mathrm{C}\right)$ hütött minták viszkozitás értékei alapján megállapítható, hogy a mikrohullámú kezelésekkel az iszap áramoltathatósága javítható, amely folyamatos üzemü iszapkezelés és a technológiai csővezetékekben való szállítás, valamint a homogenizálás esetében is előnyös. 
Az anyaggal közölt energia egy határon túli növelése - amely egyaránt elérhető a magas teljesítményszint, vagy a hosszú idejű kezelésekkel - az előnyösen növekvő szervesanyag vízoldhatóság mellett már az áramoltathatóság csökkenését okozza. A folyamatban szerepet játszó, a sejtes összetevők és a polimerek hidrolíziséből származó vegyületek a mérettartományuk révén az iszapok fázisszeparációját, különösen a szürhetőséget, már negatívan befolyásolják (Yu et al., 2009).

Amennyiben az iszapkondicionálást a süríthetőség, vagy a szürhetőség javítása céljából végzik - további biológiai hasznosítási eljárások nélkülözésével - alacsony hőmérséklet, kis energiaintenzitás, vagy rövid műveleti idő alkalmazása indokolt.

T2a: A mikrohullámú iszapkezelési eljárásnak, a szervesanyagfrakció oldhatósága szempontjából értelmezett hatékonyságát, a mikrohullámú sugárzás behatási idején túl, a kezelt anyag egységnyi tömegére vonatkoztatott, azaz fajlagos teljesítmény-intenzitás is befolyásolja. 


\subsection{A biológiailag bontható szervesanyagfrakció változásai}

A szervesanyagtartalmon belül a biológiailag lebontható frakciók kvantitatív jellemzésére, aerob lebontást feltételezve, a biokémiai oxigénigény (BOI) használható. A BOI megmutatja, a mérési időintervallumon belül, adott hőmérsékleten, a szervesanyag biológiai oxidációjához felhasznált oxigén mennyiségét a vizsgált mintában. A BOI értékét a biológiailag lebontható szervesanyag tartalom nemspecifikus összegparamétereként használja mind a szakirodalom, mind a gyakorlat.

\subsubsection{Termikus és mikrohullámú eljárás összehasonlító vizsgálata}

A BOI értéke és változási trendjei a paraméter által mért komponensek, illetve a meghatározási módszer sajátosságai révén is, a szervesanyagok vízoldhatóságának mértékéhez kötött. Ezért a vizsgálataim során a kétféle iszaptípus kezdeti BOI értéke, illetve az egyes kezelések okozta különbségek tekintetében hasonló tendenciákat vártam. A termikus és a mikrohullámú kezelés összehasonlítása céljából végzett első kísérletsorozat eredményei alapján megállapítható, hogy a mikrohullámú eljárás, megfelelő kezelési körülményeket alkalmazva, alkalmas az élelmiszeripari iszapokban a biológiailag lebontható, oldott szervesanyagok koncentrációjának növelésére, a termikus eljárásoknál nagyobb hatékonysággal (12. ábra).

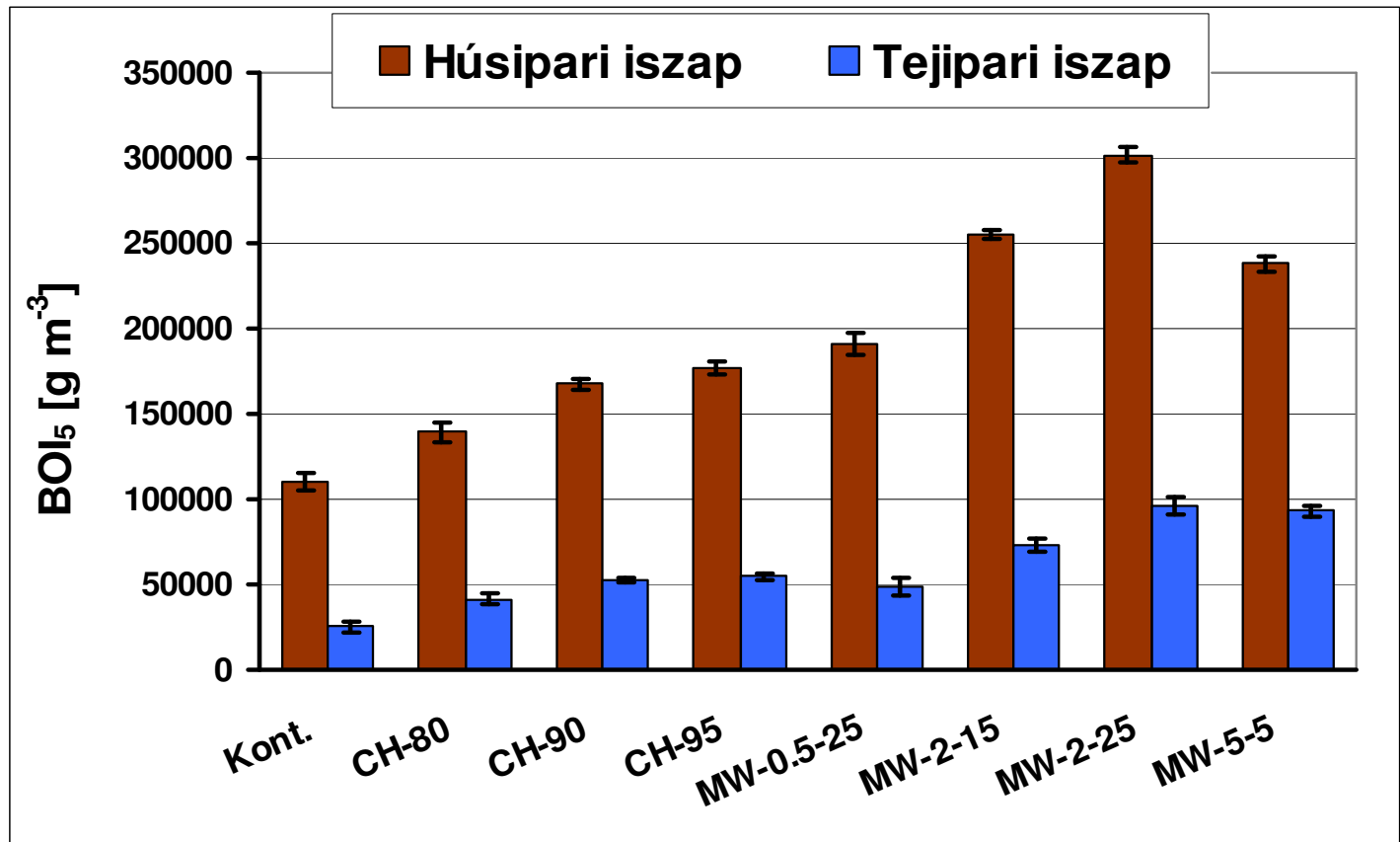

12. ábra. A biokémiai oxigénigény (BOI) változás (vizsgálati idő $=5 \mathrm{nap}, \mathrm{t}=20^{\circ} \mathrm{C}$ ) 
Az előzetes vizsgálatok során beállított teljesítmény-intenzitás és kezelési időszintek hatását tekintve a szervesanyagok oldhatóságában bekövetkezett változásokhoz viszonyítva, nem minden esetben találtam egyezést. Míg az alacsony teljesítményintenzitású, hosszabb idejü mikrohullámú kezelés (MW-0,5-25) a tejipari iszap oldott szervesanyagainak koncentrációját a termikus kezeléshez képest (CH-95) szignifikánsan növelte (7. ábra; 3. táblázat), addig a BOI-ban nem következett be számottevő, szignifikáns változás (12. ábra; 5. táblázat).

A mikrohullámú kezelések során alkalmazott müveleti paraméterek hatását vizsgálva a BOI értékek változásai alapján előzetesen megállapítható volt, hogy az alacsonyabb teljesítményszint beállítása mellett hosszú ideig végzett kezelések hatása több esetben ekvivalens a nagy teljesítmény-intenzitású, de rövidebb idejü kezelésekével.

5. táblázat. Tejipari iszap kezelések $\mathrm{BOI}_{5}$ értékre gyakorolt hatásának vizsgálata $\chi^{2}$ próbával

\section{Tejipari iszap kezelések $\chi 2$ próba eredményei}

\begin{tabular}{|l|c|c|c|c|c|c|c|}
\hline & CH-80 & CH-90 & CH-95 & MW-0.5-25 & MW-2-15 & MW-2-25 & MW-5-5 \\
\hline Kont. & 33,10 & 68,41 & 43,38 & 31,48 & 36,58 & 45,65 & 49,44 \\
\hline CH-80 & - & $\mathbf{4 , 9 8}$ & 22,96 & 11,89 & 12,02 & 14,80 & 14,84 \\
\hline CH-90 & - & - & $\mathbf{6 , 0 1}$ & $\mathbf{4 , 8 0}$ & 15,63 & 14,03 & 10,72 \\
\hline CH-95 & - & - & - & $\mathbf{7 , 1 0}$ & $\mathbf{7 , 3 8}$ & 11,39 & 8,73 \\
\hline MW-0.5-25 & - & - & - & - & $\mathbf{0 , 6 4}$ & 9,48 & $\mathbf{2 , 8 0}$ \\
\hline MW-2-15 & - & - & - & - & - & $\mathbf{2 , 2 6}$ & $\mathbf{1 , 5 2}$ \\
\hline MW-2-25 & - & - & - & - & - & - & $\mathbf{1 , 3 3}$ \\
\hline
\end{tabular}

$\chi 2_{\text {krit }}=7,78 ; D F=4 ; p<0,05$

A húsipari iszap eredeti biológiailag lebontható szervesanyagtartalma a tejipari iszapánál nagyobb, így a BOI értékének a kezelések hatására bekövetkező növekedése abszolútértékben meghaladja a tejipari iszapnál tapasztalt növekedést. Az oldhatóságnál megfigyelhető változásokkal azonos módon, de a tejipari iszap BOI értékeinek változásától eltérően, a húsipari iszap kezelésénél a nagy teljesítmény-intenzitású, rövid idejü mikrohullámú kezelés, biológiailag bontható szervesanyag frakciók növelése tekintetében, szignifikánsan kimutatható módon, kevésbé hatékony (6. táblázat), mint az alacsonyabb teljesítményszint és hosszabb idejű mikrohullámú energiaközlés alkalmazása. 
6. táblázat. Húsipari iszap kezelések $\mathrm{BOI}_{5}$ értékre gyakorolt hatásának vizsgálata

\begin{tabular}{|l|c|c|c|c|c|c|c|}
\hline \multicolumn{7}{|c|}{ Húsipari iszap kezelések $\chi 2$ próba eredményei } \\
\hline & CH-80 & $\begin{array}{c}\text { CH- } \\
\mathbf{9 0}\end{array}$ & $\begin{array}{c}\text { CH- } \\
\mathbf{9 5}\end{array}$ & $\mathbf{M W - 0 . 5 - 2 5}$ & $\mathbf{M W - 2 - 1 5}$ & $\mathbf{M W - 2 - 2 5}$ & $\mathbf{M W - 5 - 5}$ \\
\hline Kont. & 55,10 & 67,38 & 87,93 & 81,10 & 102,77 & 59,96 & 50,00 \\
\hline CH-80 & - & 22,59 & 51,20 & 53,82 & 33,97 & 24,89 & 17,96 \\
\hline CH-90 & - & - & $\mathbf{5 , 1 4}$ & 36,95 & 23,22 & 12,87 & 13,58 \\
\hline CH-95 & - & - & - & 18,66 & 16,42 & 11,45 & 15,57 \\
\hline MW-0.5-25 & - & - & - & - & $\mathbf{5 , 8 3}$ & 24,82 & 23,79 \\
\hline MW-2-15 & - & - & - & - & - & 15,67 & $\mathbf{6 , 0 7}$ \\
\hline MW-2-25 & - & - & - & - & - & - & 11,08 \\
\hline
\end{tabular}

$\chi 2_{\text {krit }}=7,78 ; D F=4 ; p<0,05$

Az előzetes kísérletek alapján azonban mindkét típusú iszap esetében megállapítható, hogy a mikrohullámú energiaközléssel végzett kezelés hatékony a BOI növelés céljából. Továbbá megállapítható, hogy a mikrohullámú teljesítmény-intenzitás (MWPL) a biológiailag bontható szervesanyag koncentráció és a kezelések optimálása szempontjából is meghatározó tényező lehet.

T1b: Élelmiszeripari iszapok esetében az atmoszferikus nyomáson végzett mikrohullámú kezelés az atmoszferikus nyomáson kivitelezett, hagyományos termikus kezelésekhez képest, rövidebb müveleti idöszüikséglet mellett, nagyobb mértékben növeli az aerob folyamatokban lebontható vegyületek koncentrációját, amely alkalmassá teszi a módszert a biológiai iszap-hasznosítási eljárások szervesanyag hasznosításának intenzifikálására. 


\subsubsection{A mikrohullámú eljárás kezelési körülményeinek hatása}

A mikrohullámú eljárás változó teljesítmény-intenzitásának hatását, az oldhatóság mellett, a BOI paraméter esetében is vizsgáltam. A biológiai lebonthatóságot jelző összegparaméterekkel kapcsolatos szakirodalmi közlemények elsősorban az anaerob körülmények közötti gáztermelődés változásait emelik ki, de a mikrohullámú eljárás esetében mind a kezelési idő, mind az alkalmazott teljesítmény vonatkozásában egyértelmü megállapításokat nem tettek. A kommunális iszapok esetében egyes közlemények a kezelések során az alkalmazott teljesítmény növelését előnyösnek ítélték meg (Toreci et al., 2009), míg más esetben ezt elhanyagolhatónak tartják (Eskicioglu et al., 2007). A kutatómunkám során ezért az egyéb kísérleti körülmények állandóságának biztosítása mellett vizsgáltam a két iszaptípus esetében a teljesítmény-intenzitás hatásait.

A saját kísérleti eredményeim alátámasztották a hipotézisemet, miszerint a fajlagos teljesítmény-intenzitás hatást gyakorol a lebontó mikroorganizmusok számára hozzáférhető iszapösszetevők koncentrációjára. A BOI változását tekintve megállapítható, hogy azonos fajlagos teljesíményszint esetében a kezelési idő, illetve azonos besugárzási időtartam alatt a fajlagos teljesítmény-intenzitás befolyásolja a biológialag könnyen oxidálható formában lévő szervesanyagok koncentrációját. A kezelések hatására bekövetkező változások időfüggése, jó illeszkedés mellett, logaritmikus telítési görbékkel írhatóak le mind a tejipari (13. ábra), mind a húsipari iszap (14. ábra) esetében.

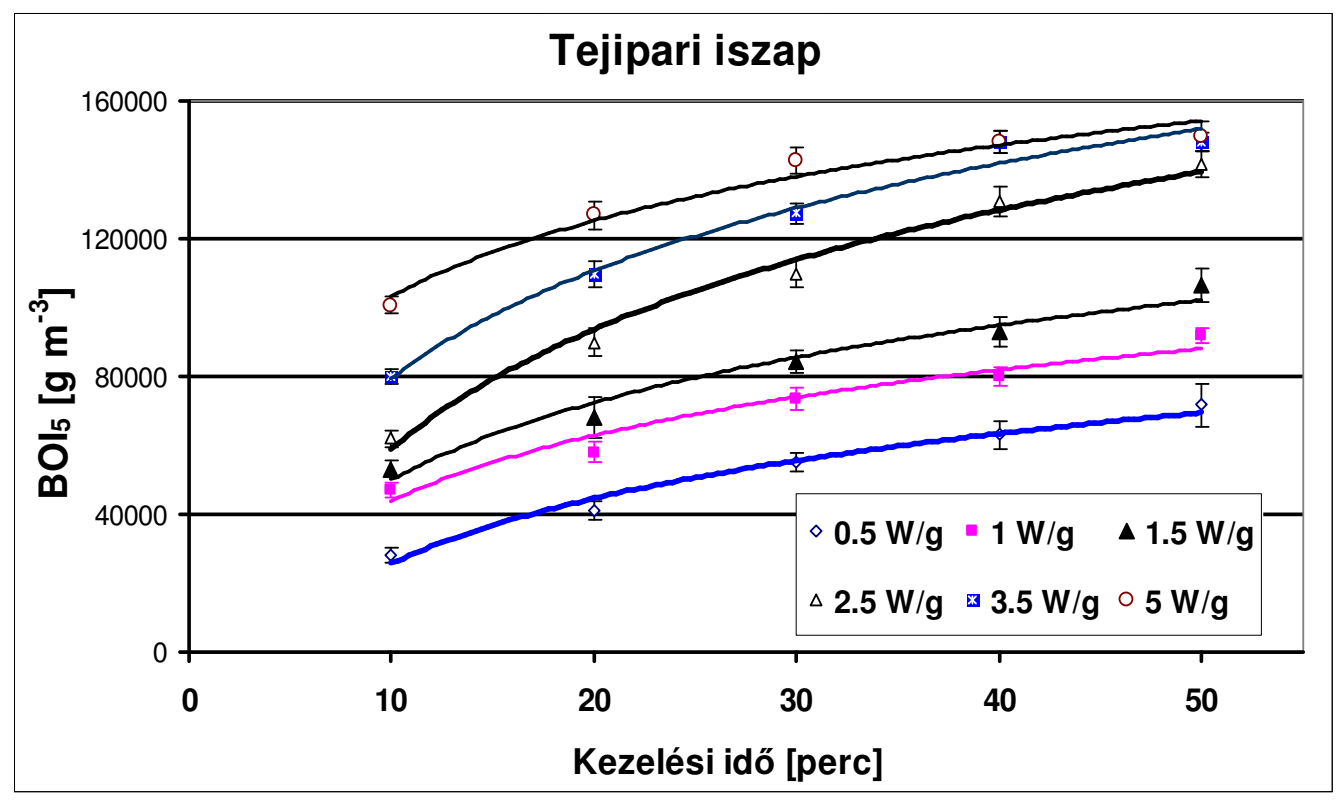

13. ábra. A BOI változása a különböző MWPL-en végzett tejipari iszap kezelések során 


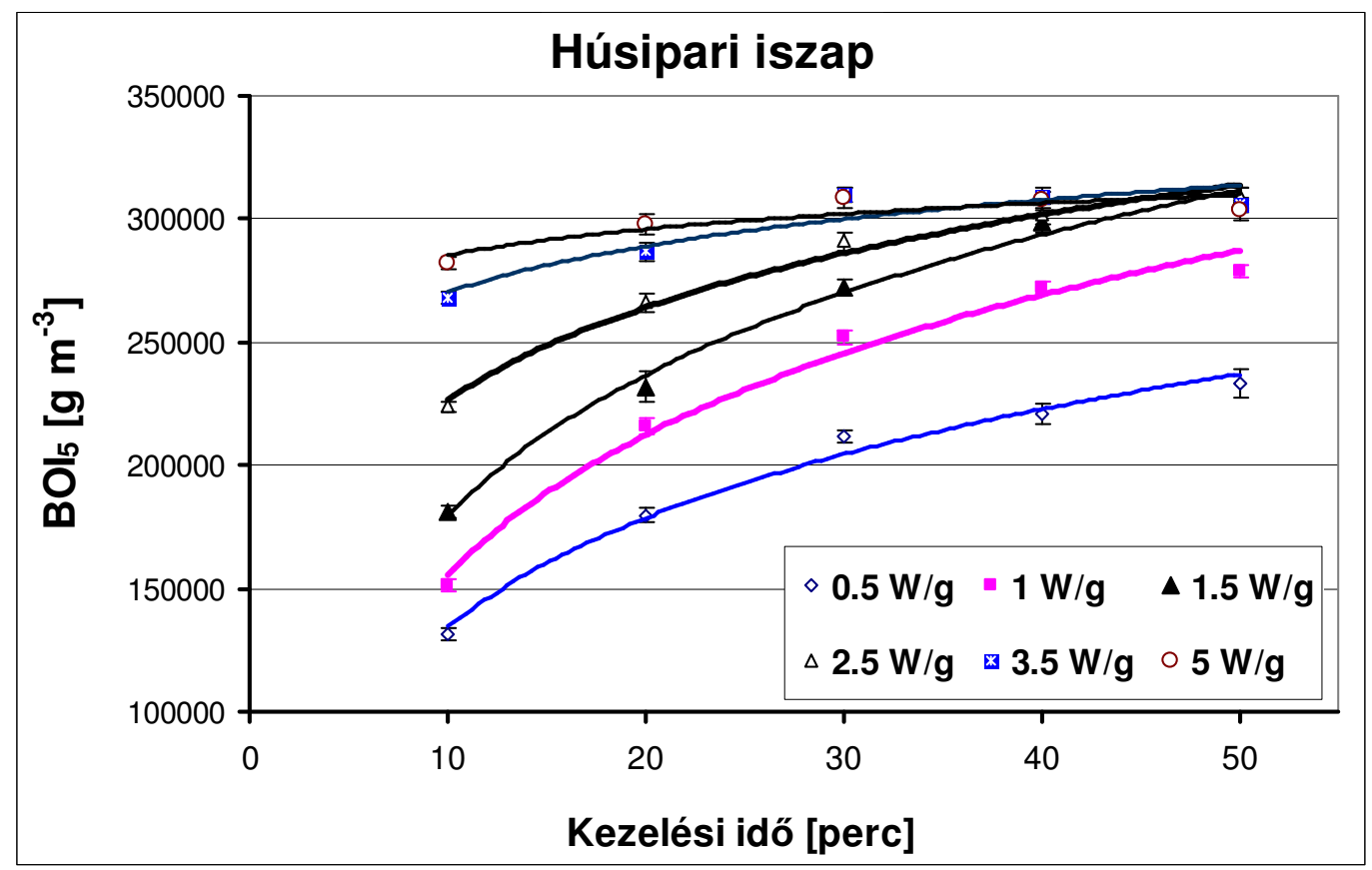

14. ábra. A BOI változása a különböző MWPL-en végzett húsipari iszap kezelések során

7. táblázat. BOI időfüggvényében való változását leíró egyenletek

\begin{tabular}{|c|c|c|c|c|}
\hline \multirow{2}{*}{$\begin{array}{c}\text { MWPL } \\
{\left[\mathbf{W g}^{-1}\right]}\end{array}$} & \multicolumn{2}{|c|}{ Tejipari iszap } & \multicolumn{2}{c|}{ Húsipari iszap } \\
\cline { 2 - 5 } & Illesztett függvény egyenlete & $\mathbf{R}^{\mathbf{2}}$ & Illesztett függvény egyenlete & $\mathbf{R}^{\mathbf{2}}$ \\
\hline 0.5 & $26985 \ln (\mathrm{x})-40439$ & 0.942 & $63721 \ln (\mathrm{x})-12309$ & 0.907 \\
\hline 1 & $27682 \ln (\mathrm{x})-22244$ & 0.896 & $81841 \ln (\mathrm{x})-32821$ & 0.982 \\
\hline 1.5 & $31162 \ln (\mathrm{x})-24538$ & 0.969 & $82089 \ln (\mathrm{x})-9242$ & 0.993 \\
\hline 2.5 & $32377 \ln (\mathrm{x})-24540$ & 0.902 & $5466 \ln (\mathrm{x})+101561$ & 0.889 \\
\hline 3.5 & $34114 \ln (\mathrm{x})-21571$ & 0.894 & $27033 \ln (\mathrm{x})+208030$ & 0.871 \\
\hline 5 & $46604 \ln (\mathrm{x})-47065$ & 0.903 & $15236 \ln (\mathrm{x})-250277$ & 0.817 \\
\hline
\end{tabular}

A mikrohullámú kezelések során a változó teljesítmény-intenzitásnak a kétféle iszaptípusra gyakorolt hatását tekintve, az oldhatóság esetében tapasztaltakhoz hasonlóan, a tejipari iszap esetében jelentősebbnek bitonyult. A húsipari iszapnál a $2,5-5 \mathrm{Wg}^{-1}$ fajlagos teljesítményszint alkalmazásakor a BOI értékének kezdeti különbségei lecsökkentek a kezelési idő növelésével. 
A 3,5 és $5 \mathrm{Wg}^{-1}$-os teljesítményszint alkalmazásánál 40 perces kezelésnél, illetve a 2,5; 3,5 és $5 \mathrm{Wg}^{-1}$ MWPL értékeknél 50 perces kezelésnél a BOI értékében, a szórások figyelembevételével 95\%-os megbízhatósági szinten kétmintás t-próbával vizsgálva szignifikáns különbség már nem mutatható ki.

A mikrohullámú energiaközlésen alapuló anyagkezelési eljárások hatásait tárgyaló tanulmányok jelentős részében a mikrohullámnak a hagyományos hőkeltési módszerekhez viszonyított legfontosabb előnyeként a jelentősen lerövidülő müveleti időt emelik ki. Az eredményeim alapján megállapítható, hogy az élelmiszeripari iszapok szervesanyagfrakcióiban végbemenő változások szempontjából a fajlagos teljesítményintenzitással befolyásolható a rövid idejű kezelések hatékonysága.

T2b: A mikrohullámú iszapkezelési eljárásnak, a biológiailag lebontható szervesanyagok koncentráció változása szempontjából értelmezett hatékonyságát, a mikrohullámú sugárzás idején túl, a fajlagos teljesítmény intenzitás, azaz a kezelt anyag egységnyi tömegére vonatkoztatott mikrohullámú teljesítmény is befolyásolja.

\subsubsection{A biológiailag bontható komponensek relatív arányának változása}

A mikrohullámú eljárással feltárt, oldott állapotba kerülő szervesanyagoknak az aerob lebontó mikroorganizmusok számára hozzáférhető és hasznosított összetevőinek mennyiségi jellemzését a BOI/KOI százalékos aránnyal is vizsgáltam. A kommunális iszapok termikus kezelésének a biológiai bonthatóság változására gyakorolt hatásának jellemzésére alkalmazott BOI/KOI hányados esetében Prorot et al. (2011) a kontroll és az előkezelt minta között nem találtak szignifikáns különbséget. A biokémiai oxigénigény mutatót alkalmazva Wojciechowska (2005) kommunális iszap esetében kimutatta, hogy a mikrohullámú kezeléssel a kémiai oxigénigénye mellett a BOI és a vizes fázisban detektálható nitrogén koncentrációja is növelhető.

A vizsgált iszapok esetében az analitikai eredményekből számított százalékos BOI/KOI arány nem követte egyértelműen sem az oldhatóság (SCOD/TCOD) sem a vizes fázisban mért BOI érték változását. A szervesanyag aerob mikrobiális lebontási folyamatokban való hasznosulást jellemző paraméter esetében, a nagy energia-intenzitású kezelések 
alkalmazásakor, egyértelmüen megállapítható volt, hogy a kezelési idő egy határon túli növelése már a mutató csökkenését okozza. Vagyis az oldhatóság változásának vizsgálata esetében megállapított hatás, miszerint a teljeítmény-intenzitás és a kezelési idő növelése korlátos, illetve a BOI esetében megállapított telítési jellegü függvénykapcsolat változásainak mértéke egy, az iszaptípustól és teljesítmény-intenzitástól függő, maximális, értéktartományt jelöl ki a BOI/KOI arány esetében. A tejipari iszapnál a kezelési idő egy határon túli növelésének negatív hatása a 3,5 és $5 \mathrm{~W} / \mathrm{g}$ fajlagos teljesíményszintek alkalmazása esetében volt tapasztalható (15. ábra)

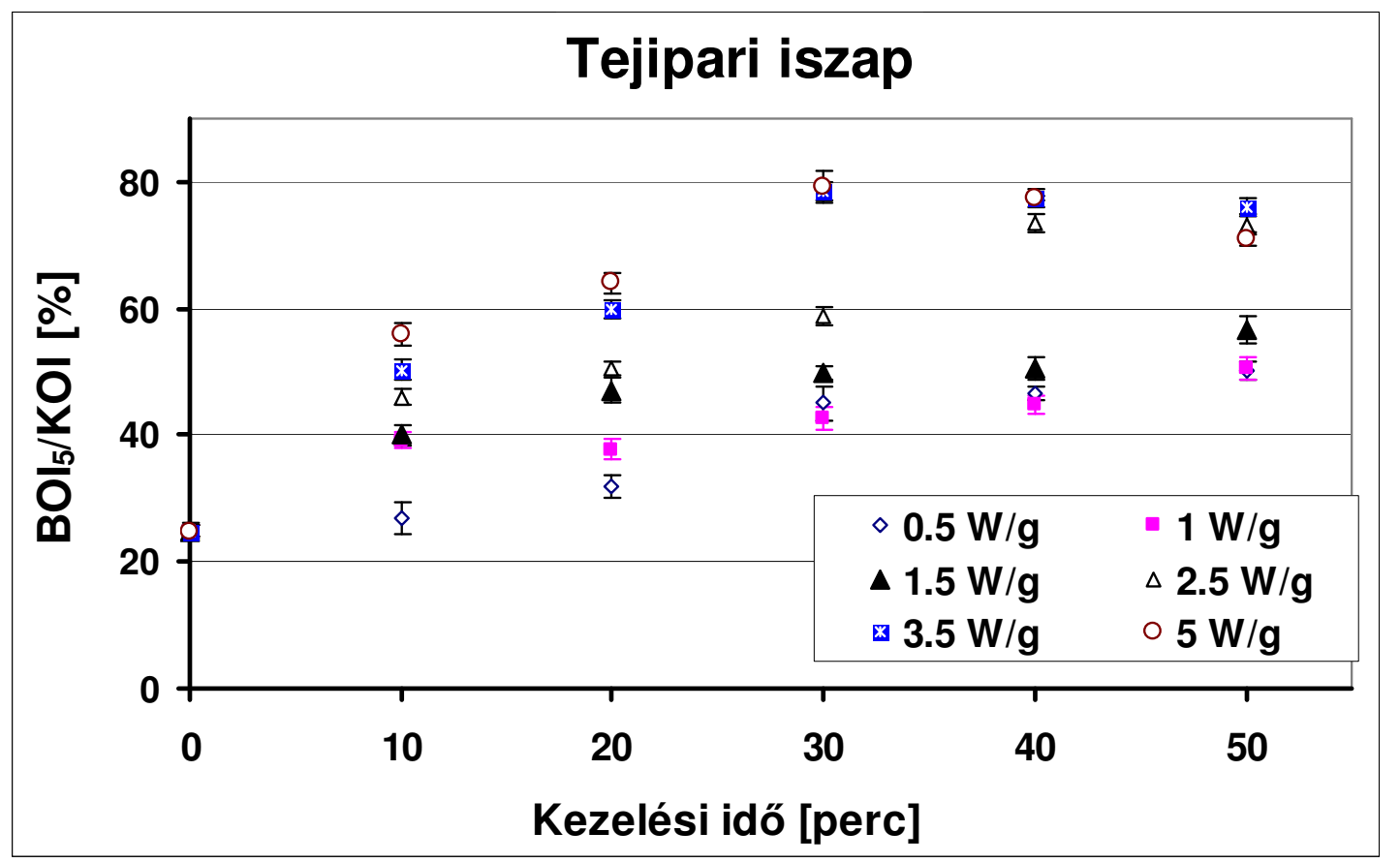

15. ábra. A BOI/KOI arány változása tejipari iszap kezelésekor

Ezen tartománynak megfeleltetett teljesítmény-intenzitás és besugárzási idő meghaladásakor a feltárt szervesanyagok aerob biológiai lebontási folyamatokban való hasznosíthatósága már romlik. A magasabb kezdeti szervesanyag tartalmú húsipari iszap esetében a 2,5; 3,5 és $5 \mathrm{~W} / \mathrm{g}$ teljesítményszintek alkalmazásakor tapasztalható a BOI/KOI arány csökkenése (16. ábra). 


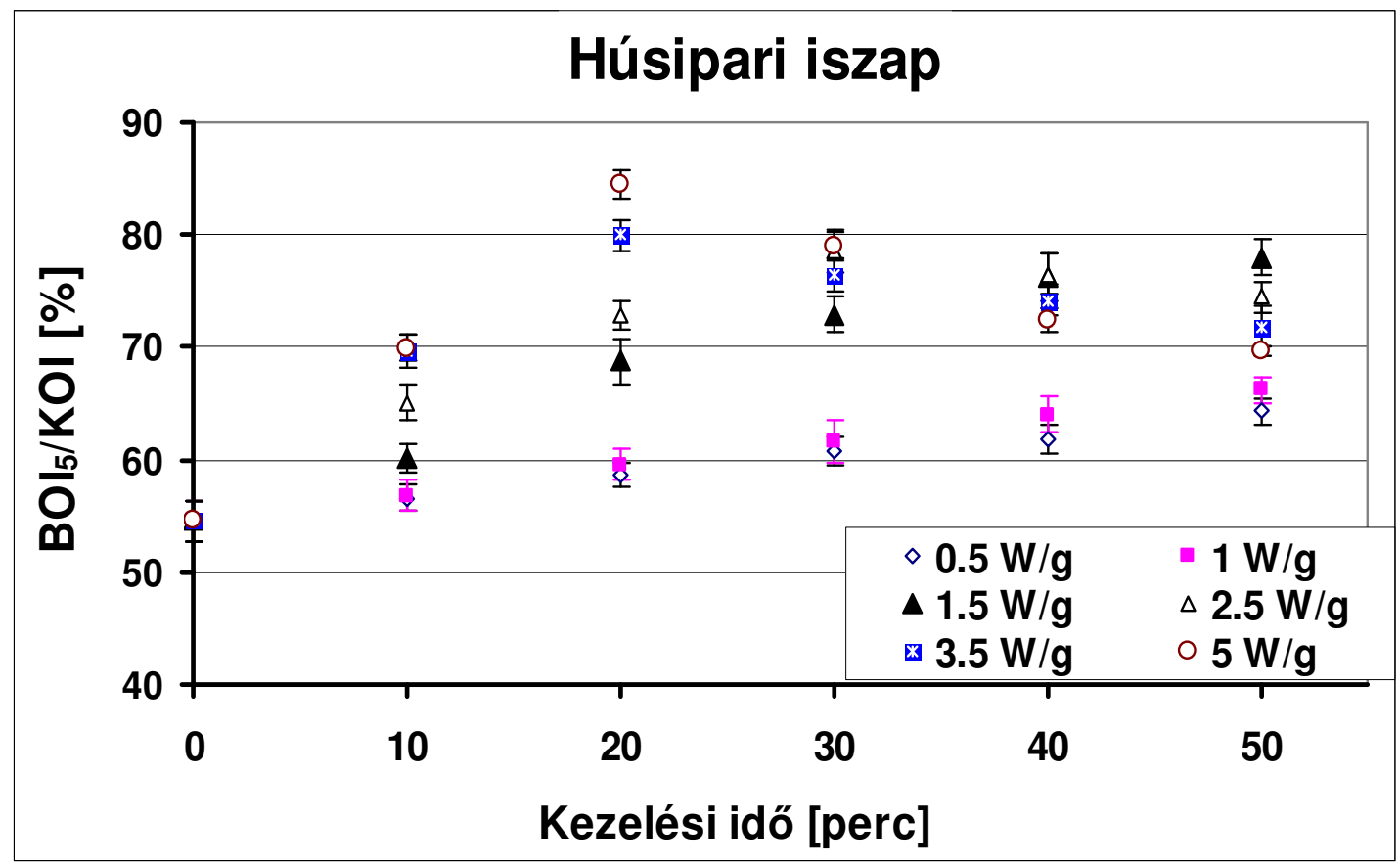

16. ábra. A BOI/KOI arány változása húsipari iszap kezelésekor

A mikrohullámú kezelések hatásait tekintve tehát megállapítható, hogy az eljárással a kezelés során feltárt és oldott álapotba került szervesanyagok aerob biológiai lebonthatósága növelhető. A biológiai lebonthatóság változását a kezelések során beállított fajlagos teljesítmény-intenzitás is befolyásolja. Továbbá mindkét vizsgált iszaptípus esetében a kezelési idő növelésekor, nagy teljesítmény-intenzitást alkalmazva az aerob szervesanyag hasznosíthatósággal összefüggő mutató csökkenő tendenciájú szakaszba megy át.

Az iszap szerkezetét részben meghatározó EPS frakció a sejteket érő hőstressz szempontjából védő funkcióval rendelkezik. Az iszap mikrohullámú kezelésekor az első szakaszban a közölt energia az EPS roncsolására hasznosul, majd a következő szakaszban a sejtfalak felszakítása következik. A sejtmembránok felbomlásával, illetve a kezelések során a fehérjék részleges hidrolízisével az ammónia-nitrogén koncentrációja a vizes fázisban növekszik (Eskicioglu et al., 2007; Kuglarz et al., 2013). 
A hidrolízis, és ennek következtében a molekulaméret csökkenésével könyebbé váló biológiai lebonthatóság, ezek alapján indirekt módon, az ammónia vegyületek okozta pH változással is nyomonkövethető. A mérési eredményeimben elsősorban a magasabb fehérjetartalommal rendelkező húsipari iszap esetében tapasztaltam a mikrohullámú kezelések következtében létrejövő pH változást (17. ábra). Azonos kezelési időt alkalmazó, de növekvő teljesítményintenzitású kezeléseknél, illetve ugyanazon teljesítményszint mellett a kezelési időt növelve az iszap pH-jának növekedése, majd állandósulása volt

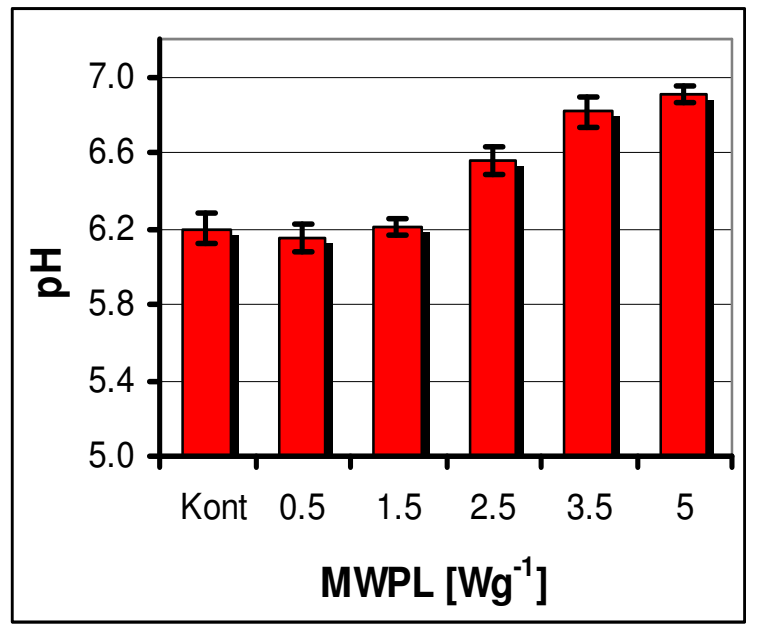

a)

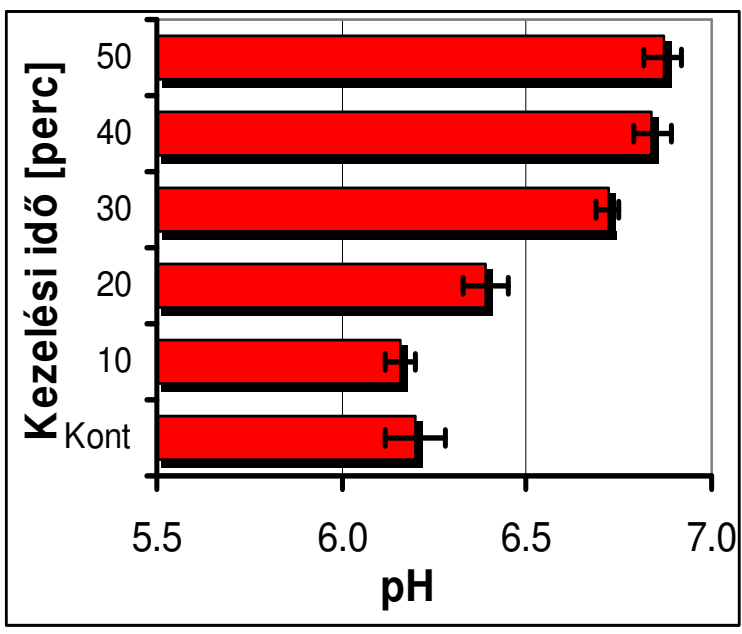

b)

17. ábra. A pH változása a teljesítmény intenzitás ( $\mathrm{t}=40$ perc) a) és a kezelési idő b) függvényében $(\mathrm{MWPL}=3,5 \mathrm{~W} / \mathrm{g})$

A nagy energia-intenzitású, hosszú kezelési időt alkalmazó nyitott rendszerekben kivitelezett mikrohullámú kezelések esetében leírt ammónia eltávozáshoz köthető pH csökkenést (Eskicioglu et al., 2008a) az általam alkalmazott kísérleti elrendezésben, élelmiszeripari iszapok esetén nem tapasztaltam.

Rövid idejü mikrohullámú kezelések esetében a fajlagos teljesítmény-intenzitás értéke meghatározó, a tejipari iszapok esetében a 10 perces kezeléseket alkalmazva a 0,5-5 W/g tartományban a fajlagos teljesítményszint növelés a BOI/KOI arány folyamatos növekedését okozza.

Ugyanezen kezelési paramétertartományban a húsipari iszap esetében a magasabb -3,5 és $5 \mathrm{~W} / \mathrm{g}$ - teljesítményszintek hatásának különbsége kétmintás t próbával vizsgálva 95\%-os megbízhatósági szinten már nem szignifikáns ( $\mathrm{t}=1,747$; $\left.\mathrm{t}_{\mathrm{krit}}=.4,303\right)$. 
Az energiaközlés behatási idejét növelve a teljesítmény-intenzitásnak a BOI/KOI arányra gyakorolt hatása mérséklődik. A húsipari iszap esetében a 40 perces kezeléseknél a 1,$5 ; 2,5$ és $5 \mathrm{~W} / \mathrm{g}$, a tejipari iszapnál a 3,5 és $5 \mathrm{~W} / \mathrm{g}$ teljesítményszintek hatásai közötti különbség a kétmintás t-próbák eredményei alapján nem tekinthető szignifikánsnak (18. ábra).
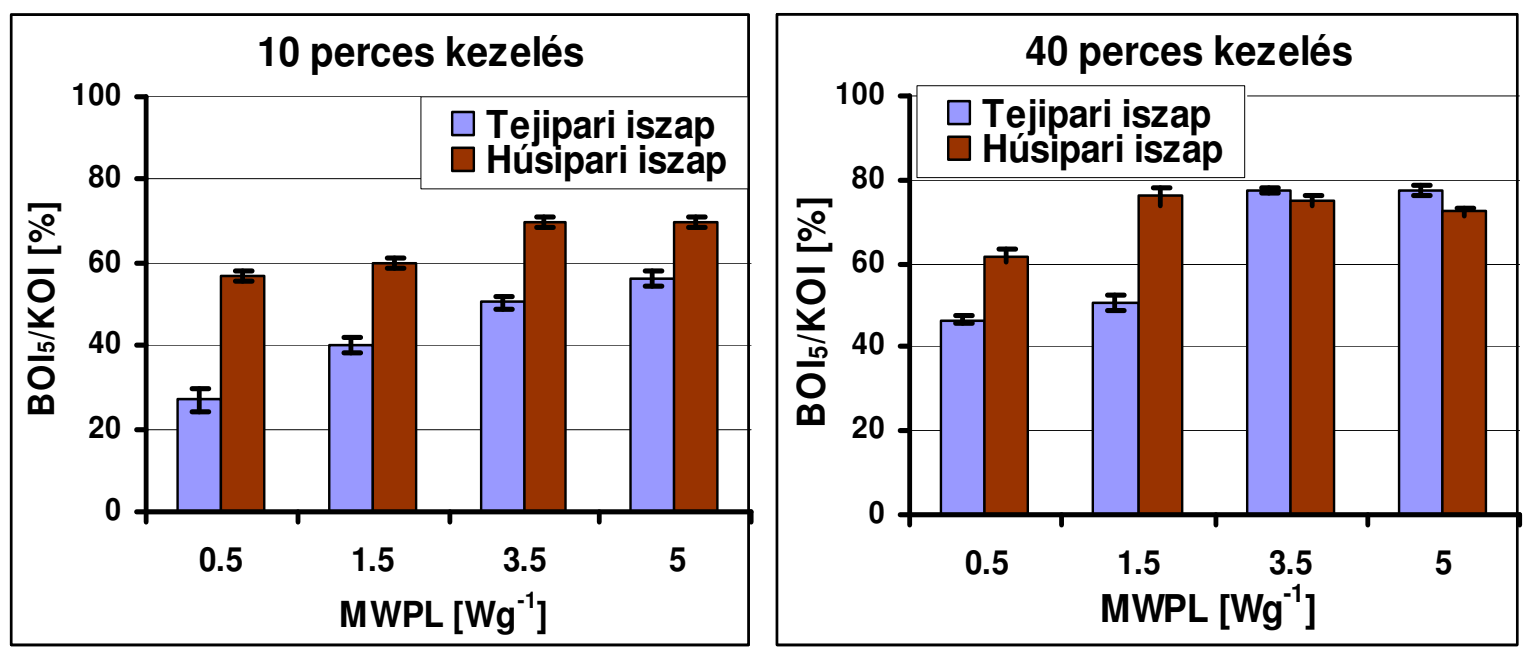

18. ábra. A BOI/KOI arány 10 és 40 perces kezeléseknél

A teljesítményszint által is meghatározott, maximum értékkel jellemzhető BOI/KOI-idő összefüggés a későbbiekben a műveleti paraméterek optimálásakor meghatározó jelentőségü lehet. 


\subsection{Mikrohullámú iszapkezelés múveleti paramétereinek optimálása}

A mikrohullámú iszapkezelési eljárás müveleti paramétereinek matematikai modellezéséhez és a folyamat optimálásához, a szakirodalmi és a saját mérési eredményeim ismeretében először olyan mutatókat fejlesztettem, amelyek alkalmasak az élelmiszeripari iszapok szervesanyagainak vízoldhatóságában, valamint az aerob biológiai lebonthatóság változásában végbement változások objektív jellemzésére.

\subsubsection{Mikrohullámú kezelés jellemzésére alkotott paraméterek}

Az iszapok összetételében mutatkozó fluktuáció, illetve az eltérő eredet következtében szükségessé vált olyan paraméterek kifejlesztése, amelyek a kezeléseknek az iszap szerkezetében és biológiai bonthatóságában bekövetkező változásokat számszerűen és objektíven jellemzik. A hagyományos termikus és a mikrohullámú iszapkezeléseket tárgyaló szakirodalmi közlemények legtöbbjében az iszappelyhek dezintegrálódásának és a szervesanyagok oldhatósági változásának jellemzésére a vízoldható kémiai oxigénigény (SCOD), illetve egyes esetekben a SCOD és teljes kémiai oxigénigény (TCOD) arányát használják. Az iszap szilárd fázisában (iszapot alkotó részecskékben) lévő szervesanyag tartalom (PCOD) a TCOD és SCOD érték különbségeként értelmezhető. Ez a paraméter azonban nem veszi figyelembe a kezeletlen iszap eredeti tulajdonságait és a százalékos növekmények összehasonlítása nehézkes, illetve ezek értékelésekor sok esetben nem tehetőek egyértelmű megállapítások, javaslatok.

A munkám célja, olyan mutató kifejlesztése, amellyel az élelmiszeripari szennyvíziszapok mikrohullámú kezelésének hatékonysága, az iszapok szervesanyag tartalmának oldhatóságában végbemenő változások tekintetében objektíven és egyértelmüen összehasonlíthatóvá válik. Az általam alkotott oldhatósági index (SLIsolubility index) a kémiai oxigénigény mérésén alapul, amelynek módját a KOI meghatározás leírásánál részleteztem. Az index számítása során figyelembe vettem az iszapminta kezdeti szervesanyag oldhatóságát (SCOD/TCOD) $)_{0}$, illetve ezen paraméteraránynak a kezelés utáni értékét (SCOD/TCOD)t. 
Viszonyítási alapként az adott minta esetében elérhető maximális szervesanyag oldhatóság (SCOD/TCOD) $\max$ értékét választottam. Ennek meghatározására - az elfogadott standard módszer hiánya miatt - a szakirodalomban található, és több tudományos munkában felhasznált módszert alkalmaztam (Eskicioglu et al., 2008b), azonban ebben, a különböző iszaptípus miatt, a hőmérséklet, lúgadagolási arány nem egységes.

Az általam vizsgált iszapok esetében, az előkísérleteim eredményei alapján, a maximális oldhatóság az iszapminta tömegére vonatkozóan 10-szeres, lúgos - pH 12 kémhatású nátrium-hidroxid oldattal történő hígítást követő 10 órás, $60^{\circ} \mathrm{C}$-os hőntartás után mérhető. Az oldhatósági indexet mindezek figyelembevételével a következő összefüggéssel határoztam meg:

$$
\text { SLI }=\frac{\left(\frac{\text { SCOD }}{\text { TCOD }}\right)_{t}-\left(\frac{\text { SCOD }}{\text { TCOD }}\right)_{0}}{\left(\frac{\text { SCOD }}{\text { TCOD }}\right)_{\max }-\left(\frac{\text { SCOD }}{\text { TCOD }}\right)_{0}} \quad[-]
$$

A biológiai bonthatóság változását jellemző paraméterek tekintetében a szakirodalom a biokémiai oxigénigényt, illetve az anaerob fermentáció egyes paramétereit (képződő biogáz térfogata, illetve folyamatos fermentáció esetén a hidraulikus tartózkodási idő változása, a szervesanyag eltávolítás hatásfoka) határozza meg. A kezelések alkalmazása esetében azonban figyelembe kell venni, hogy az eltérő eredet és összetétel következtében önmagukban ezek a paraméterek nem alkalmasak a kezelések hatékonyság-vizsgálatára.

A standardizált mérési metódusokkal meghatározható nem-specifikus szervesanyagterhelési paraméterek (BOI, KOI) felhasználásával definiáltam a biodegradálhatósági indexet (BDI-biodegradation index), amelynek értéke megmutatja, hogy a kezelések hatására a vízoldható formában lévő, vagy került szervesanyagokon belül az aerob módon lebontható vegyületcsoportok milyen arányban növekednek.

A BDI számítása során a kezeletlen iszap kezdeti és t kezelési idő után mért biokémiai oxigénigény (BOD) és vízoldható szervesanyag tartalmának (SCOD) változását hasonlítottam a maximálisan vízoldhatóvá tett szervesanyagtartalmú iszap BOD és SCOD arányának kezdeti értékhez viszonyított arányához. 


$$
\text { BDI }=\frac{\left(\frac{\text { BOD }}{\text { SCOD }}\right)_{t}-\left(\frac{\text { BOD }}{\text { SCOD }}\right)_{0}}{\left(\frac{\text { BOD }}{\text { SCOD }}\right)_{\max }-\left(\frac{\text { BOD }}{\text { SCOD }}\right)_{0}} \quad[-]
$$

A kezelések szennyvíziszapokra gyakorolt hatásának jellemzésére alkotott paraméterek, valamint a mérési és mintaelőkészítési módszerek összefüggését a következő folyamatábrán szemléltetem.

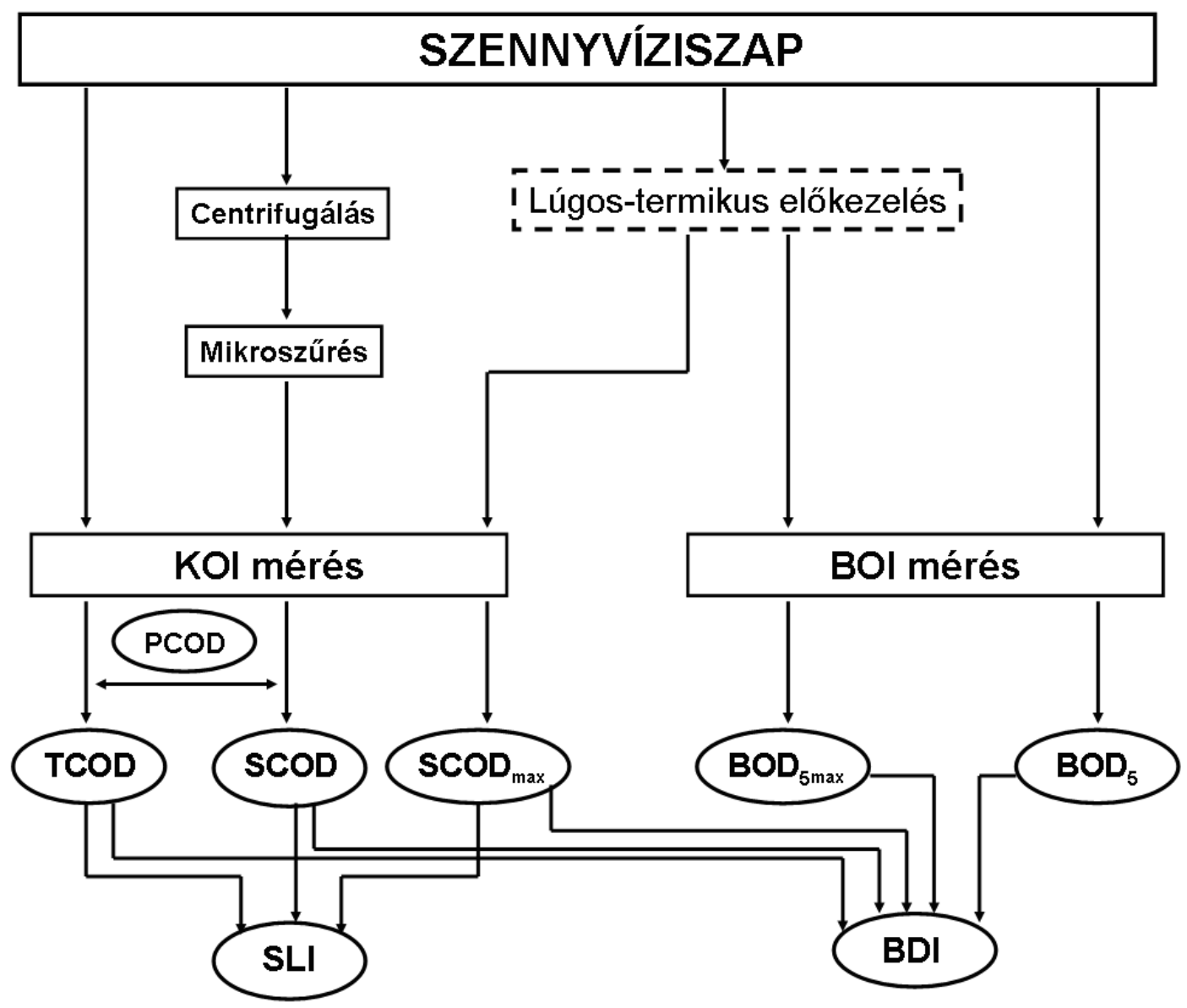

19. ábra. A mért szervesanyag mutatók és a kezelések hatékonyságának jellemzésére alkotott paraméterek kapcsolata és meghatározása 


\subsubsection{Mikrohullámú kezelés múveleti paramétereinek optimálása}

A kémiai-, illetve biokémiai oxigénigény és ezek arányának változásaira vonatkozó kísérleti eredményeim alapján a modellezés és a folyamatparaméterek optimálása esetében végzett kísérleteimhez a fajlagos mikrohullámú teljesítmény-intenzitás (MWPL) szintjeit 0,5-2,75-5 $\mathrm{Wg}^{-1}$ értéknek választottam. A fajlagos teljesítményszintek változtatása miatt, a sugárzási idő helyett, az anyaggal a mikrohullámú kezelés során közölt fajlagos energia (IMWE) paramétert választottam, amelyet 90 - $570-1050 \mathrm{kJg}^{-1}$ értékek beállításával változtattam húsipari eredetű iszap alapanyag esetében. Az elsősorban a mikrohullámú szárítási eljárások vizsgálatával foglalkozó szakirodalmi közlemények eredményei alapján vizsgáltam továbbá a szakaszos üzem esetén a százalékos kezelési idő (I) hatását is. A mủveleti paramétereket, illetve az oldhatósági index (SLI) és a biodegradálhatósági index (BDI) értékeit a 8. táblázat tartalmazza.

8. táblázat. Kísérleti paraméterek és eredmények táblázata

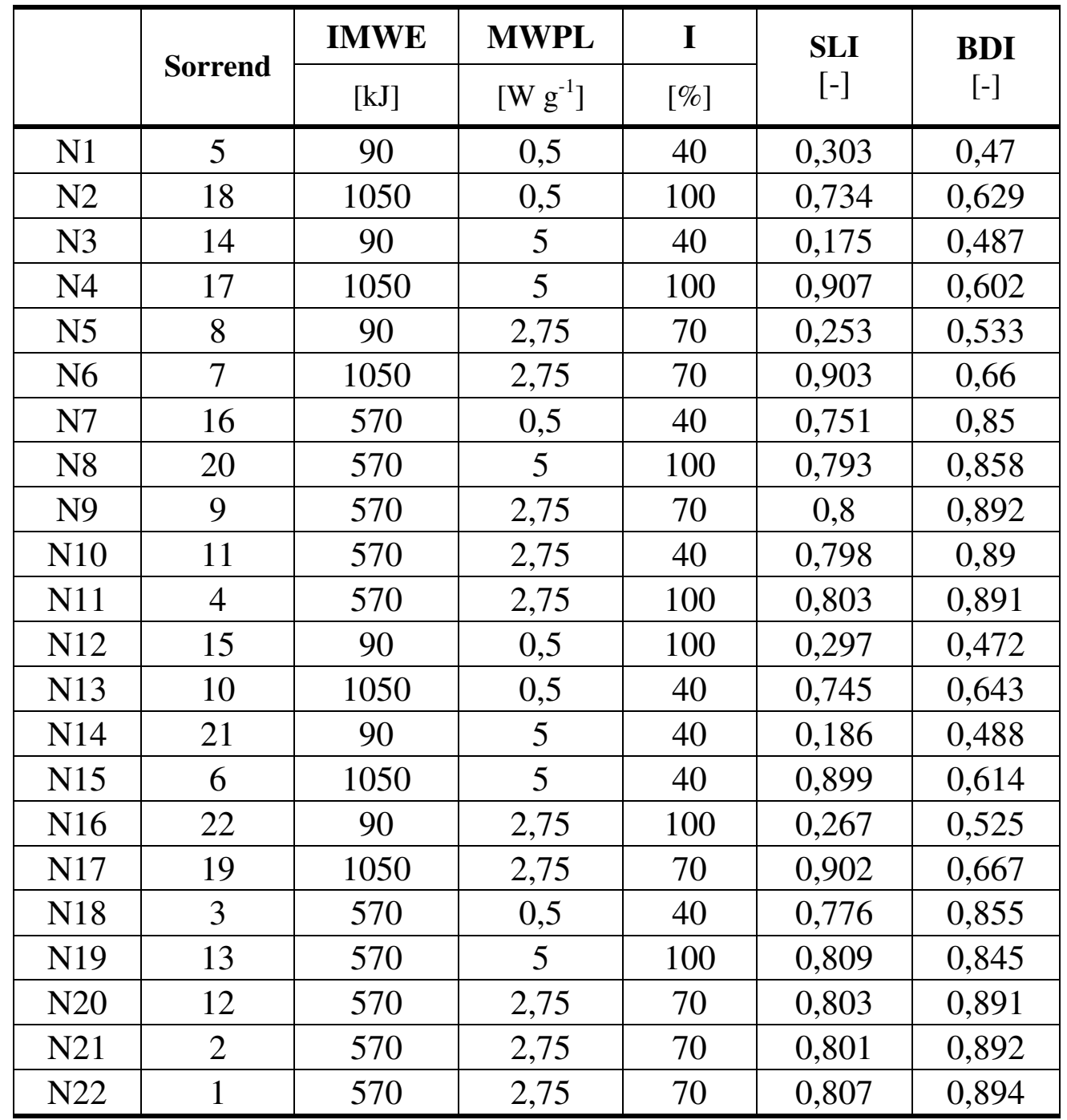


A kísérlettervezéshez kompozit kísérlettervet, a matematikai modellalkotáshoz és optimáláshoz többszörös lineáris regressziót (MLR) és válaszfelület elemzési módszert (RSM) választottam, amelyekhez MODDE 8.0 (Umetrics, Sweden) statisztikai szoftvert használtam. A kísérleti sorrendet a mérések elvégzésekor adódó hibák valószínüségének csökkentése érdekében randomizáltam.

Az egyes müveleti paraméterek, illetve ezek interakcióinak hatását az oldhatósági indexre (SLI) a 20. ábrán szemléltetem. A paraméterek hatása a grafikus ábrázolás alapján akkor tekinthető szignifikánsnak, ha azok, vagyok azok interakcióinak konfidenciaintervalluma nem foglalja magában a zérus értéket.

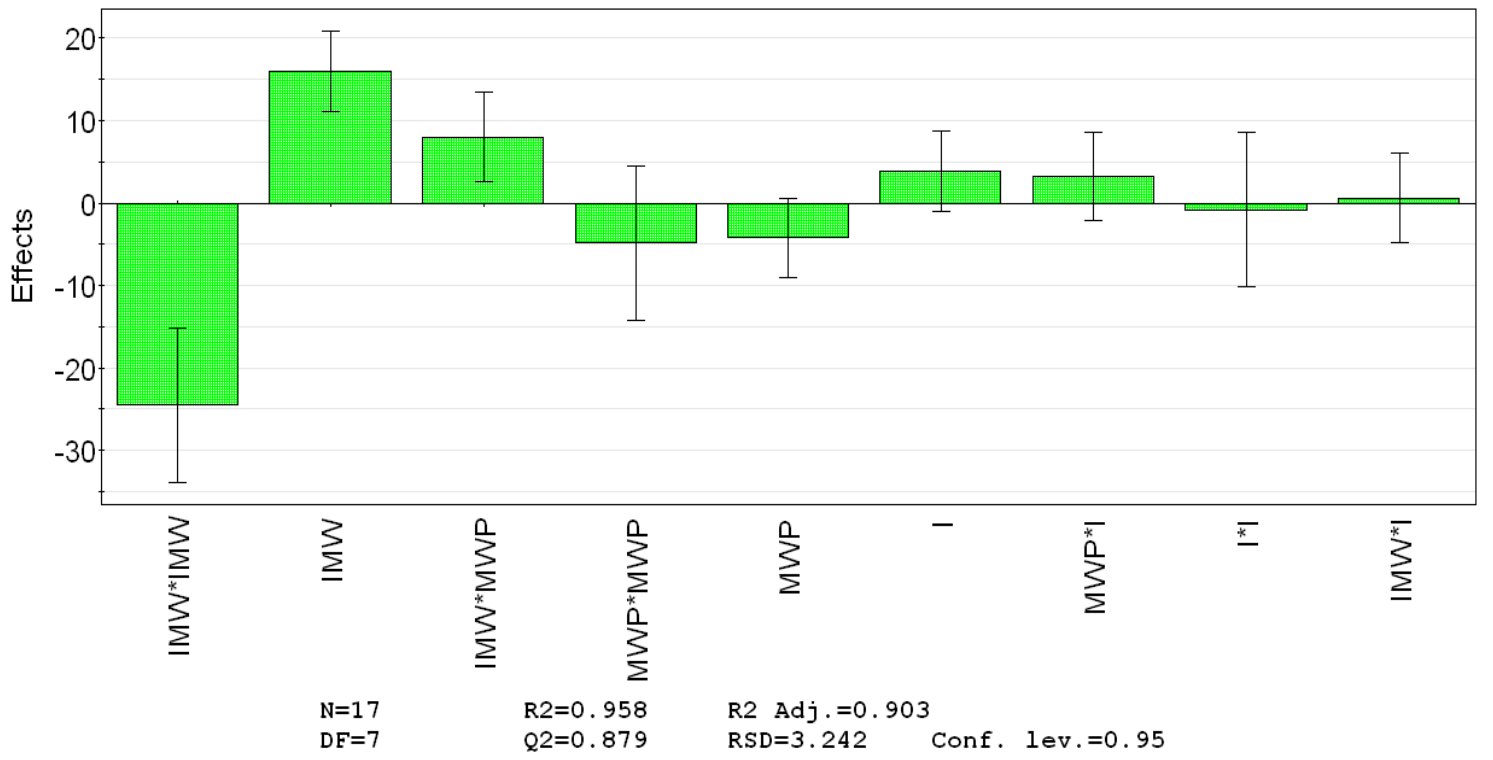

20. ábra. A müveleti paraméterek hatása az SLI értékére

A kommunális iszapok mikrohullámú kezelésekor Yu et al. (2010) a kezelések során közölt energia növelésének az iszapszerkezet felbomlására gyakorolt szignifikáns hatásáról számolnak be. Azonban kombinált mikrohullámú-lúgos kezelése kapcsán Yang et al. (2013) megállapították, hogy a pH mellett a fajlagos térfogati energiabevitel is hatást gyakorol az iszaprészecskék dezintegrálódásával összefüggő vízoldható szervesanyagtartalom változására, azonban a közölt energia növelése egy határon túl már nem okoz további oldhatósági változást. 
A húsipari eredetü szennyvíziszap kezelésekor kapott saját eredményeim alapján megállapítható, hogy a mikrohullámú iszapkondicionálás során az anyaggal közölt energia (IMWE), illetve a fajlagos teljesítmény-intenzitás (MWPL), illetve a két vizsgált műveleti paraméter kölcsönhatása egyaránt szignifikáns hatással van az oldhatósági index (SLI) értékére 95\%-os megbízhatósági szinten.

A szakaszos üzemü kezelések esetében egy adott időintevallumon belül a sugárzási/sugárzásmentes intervallumok változása, a vizsgált tartományon belül nem gyakorolt jelentős hatást az oldhatóság mértékére. A nem szignifikáns tényezőket figyelmen kívül hagyva, az újbóli illesztés a következő [33] másodfokú polinomot eredményezte, ahol $\mathrm{x}_{1}$ jelöli az IMWE, $\mathrm{x}_{2}$ pedig az MWPL paramétert.

A kísérleti paraméterek részletezésénél leírt MWPL (0,5-5 $\left.\mathrm{Wg}^{-1}\right)$ és IMWE (90-1050 $\mathrm{kJg}^{-1}$ ) tartományban érvényes modell mindkét változóra tartalmazott lineáris és négyzetes tagot, illetve lineáris interakciót a két változó között.

$$
\mathrm{SLI}=0,8085+0,301 x_{1}+0,014 x_{2}+0,0706 x_{1} x_{2}-0,237 x_{1}^{2}+0,036 x_{2}^{2}
$$

Az alkotott modell validitását variancianalízissel (ANOVA) vizsgáltam, amelynek az eredményét a 9. táblázatban foglaltam össze.

9. táblázat. Varianciaanalízis eredménye az SLI esetében meghatározott modellre

\begin{tabular}{|l|c|c|c|c|c|c|c|}
\hline & DF & SS & MS & F & F $_{\text {krit }}$ & p & SD \\
\hline Alapadatok & 21 & 1,4700 & 0,0070 & & & & 0,2646 \\
\hline Modellel becsült & 5 & 1,4657 & 0,2930 & 1012,11 & 2,85 & 0,0001 & 0,5414 \\
\hline Maradvány & 16 & 0,0046 & 0,0003 & & & & 0,0170 \\
\hline Illeszkedési hiba & 3 & 0,0039 & 0,0013 & 22,16 & 3,41 & 0,38 & 0,0359 \\
\hline Hiba & 13 & 0,0007 & 0,0001 & & & & 0,0076 \\
\hline
\end{tabular}

DF: szabadsági fok, SS: négyzetösszeg, MS: variancia, SD: standard deviation (tapasztalati szórás), $F_{\text {krit }}$ :95\% megbízhatósági szintre számított F érték, SD: standard eltérés 
A polinomra illesztett válaszfelület kétdimenziós metszetét a 21. ábrán szemléltetem. A számított korrelációs együttható négyzete megfelelő $\left(\mathrm{R}^{2}=0,943\right)$. Az illeszkedés 'jósági' (pontossági) mutatója (goodness of fit) szintén megfelelőnek tekinthető $\left(\mathrm{Q}^{2}=0,921\right)$.

A válaszfelület elemzése alapján megállapítható, hogy a szervesanyagok oldhatósága szempontjából a mikrohullámú kezelés során az anyaggal közölt fajlagos energiát (IMWE) tekintve a $650 \mathrm{kJg}^{-1}$ - $1050 \mathrm{kJg}^{-1}$ tartomány, a fajlagos teljesítmény-intenzitást (MWPL) tekintve a $2 \mathrm{Wg}^{-1}-5 \mathrm{Wg}^{-1}$ paramétertartomány tekinthető optimálisnak.

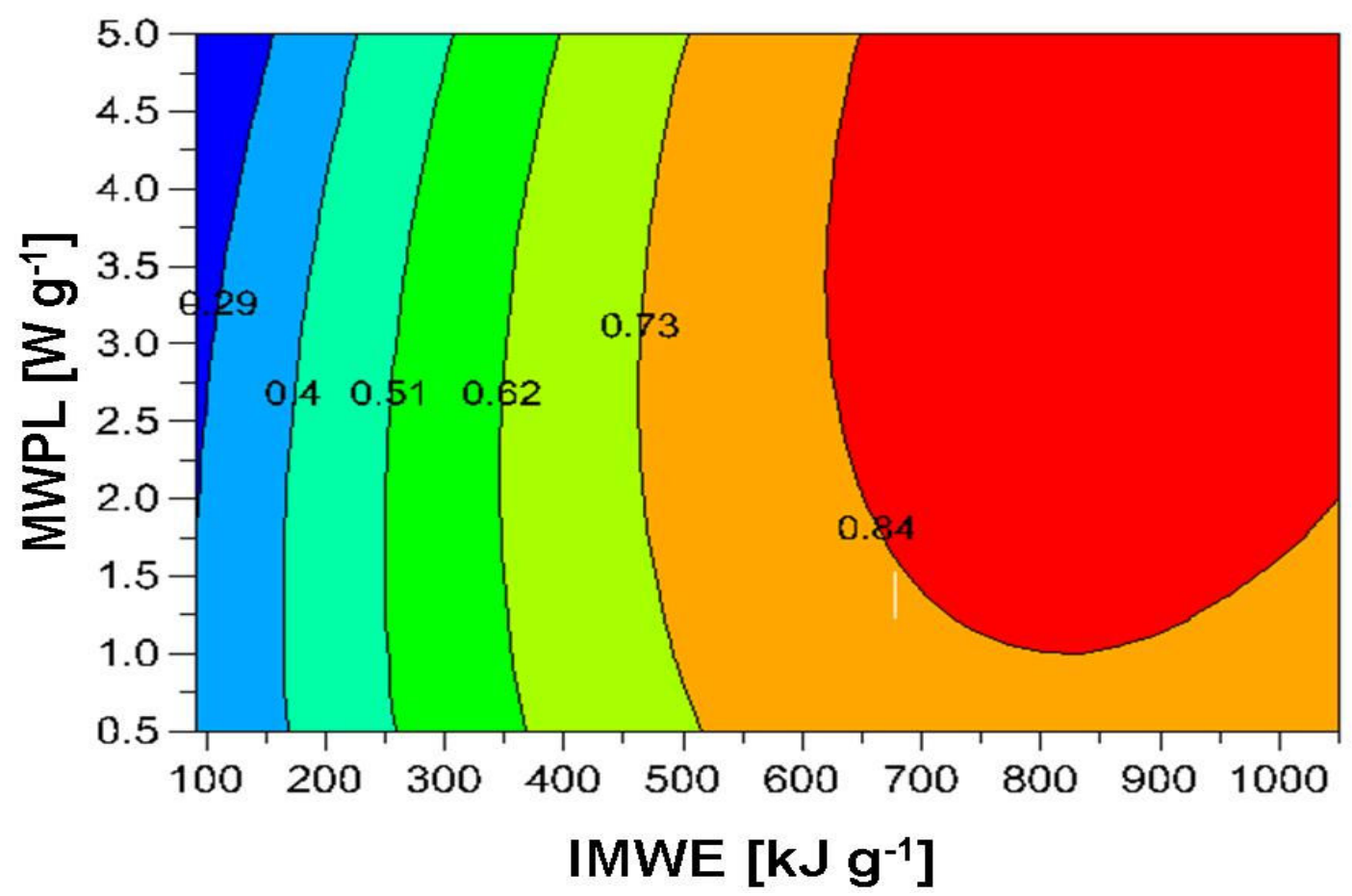

21. ábra. Az SLI esetében kapott válaszfelület 2D metszete

A nem szigifikáns hatású változókat, illetve kölcsönhatásokat mellőzve az illesztést a biodegradálhatósági index (BDI) esetében elvégezve, a megadott MWPL=0,5-5 $\mathrm{Wg}^{-1}$; illetve IMWE=90-1050 $\mathrm{kJg}^{-1}$ tartományban érvényes [34] összefüggést kaptam (a változók kódolása a [33] egyenletnek megfelelő).

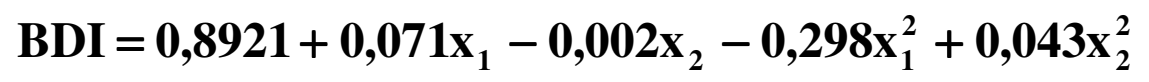

A [34] modell érvényességi tartomány: $\mathrm{MWPL}=0,5-5 \mathrm{Wg}^{-1}$; illetve IMWE=90-1050 $\mathrm{kJg}^{-1}$.

A modell esetében elvégzett variancianalízis eredményét a 10. táblázatban adtam meg (a jelölések megegyeznek a 9. táblázatban alkalmazottal). 
10. táblázat. Varianciaanalízis eredménye az BDI esetében

\begin{tabular}{|l|c|c|c|c|c|c|c|}
\hline & DF & SS & MS & F & F $_{\text {krit }}$ & p & SD \\
\hline Alapadatok & 20 & 0,5941 & 0,0070 & & & & 0,1682 \\
\hline Modellel becsült & 5 & 0,5936 & 0,2930 & 323,50 & 2,90 & 0,0001 & 0,3446 \\
\hline Maradvány & 15 & 0,0004 & 0,0003 & & & & 0,0052 \\
\hline Illeszkedési hiba & 3 & 0,0039 & 0,0000 & 11,31 & 3,49 & 0,314 & 0,0158 \\
\hline Hiba & 12 & 0,0007 & 0,0003 & & & & 0,0050 \\
\hline
\end{tabular}

A korrelációs együttható, illetve a jósági tényező értéke alapján a modell illeszkedése megfelelő $\left(\mathrm{R}^{2}=0,917 ; \mathrm{Q}^{2}=0,909\right)$. Az SLI kontrollparamétertől eltérően a BDI esetében megállapítható, hogy bár annak értékét a két vizsgált mủveleti paraméter az IMWE és az MWPL szintén befolyásolja, azonban ezek egy bizonyos határértéken túli további növelés már negatívan hat a biológiai lebonthatóságra.

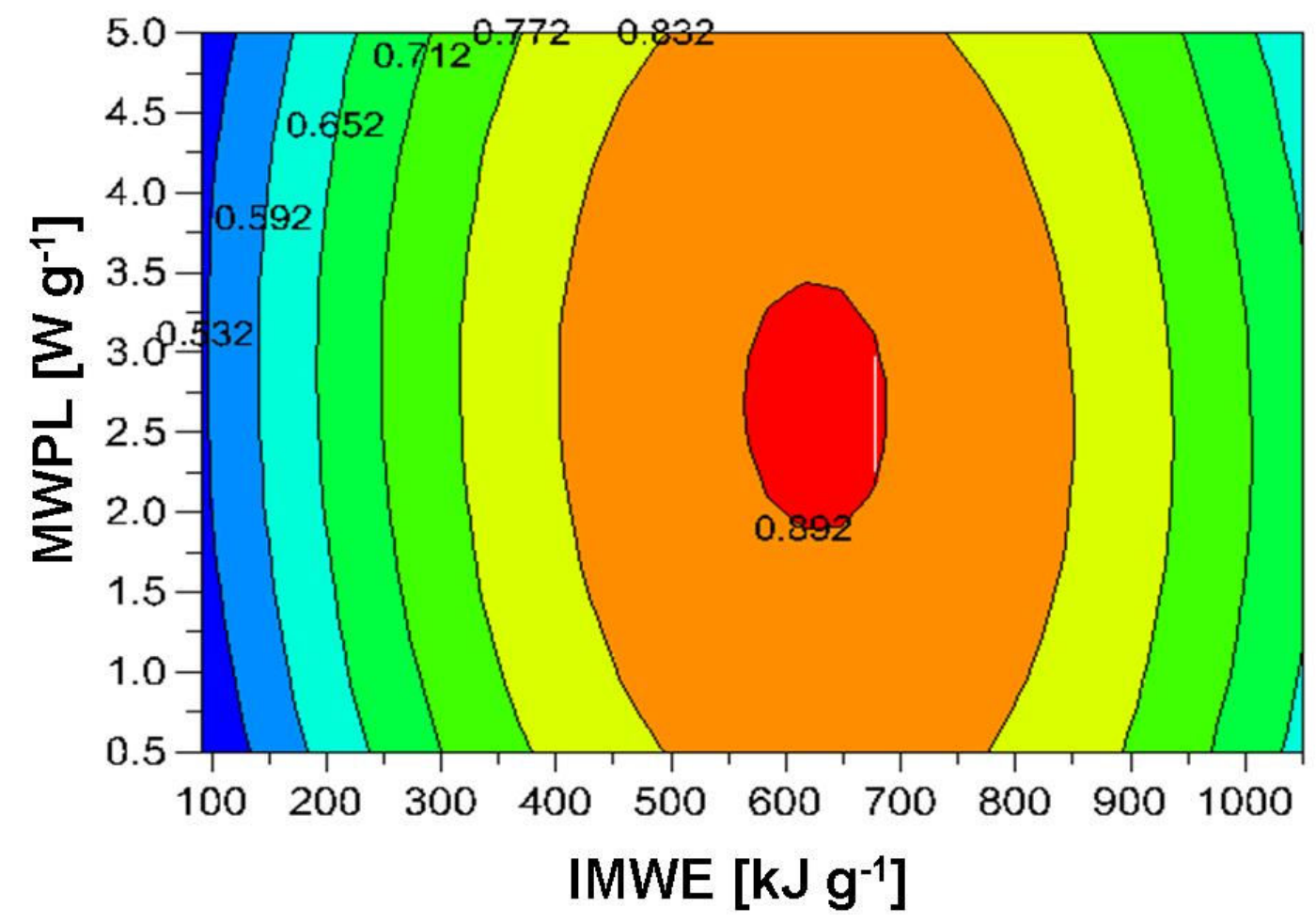

22. ábra. Az BDI esetében kapott válaszfelület $2 \mathrm{D}$ metszete 
A mikrohulámú energiaközléssel az iszapszerkezet stabilitását biztosítő EPS frakció, továbbá az iszappelyhek hatékony felbomlását követően a szervesanyagok feltáródnak, a koncentrációjuk az iszapvízben növekszik. Azonban a magas energiájú és/vagy nagy teljesítményủ mikrohullámú kezelések következtében olyan szerkezeti és kémiai változások következhetnek be, amelyek a szervesanyagoknak az aerob mikrobiális lebontási folyamatokban való hasznosulásának hetékonyságát már rontják.

A válaszfelület kétdimenziós metszete (22. ábra) alapján az aerob biológiai lebonthatóság szempontjából legkedvezőbb paramétertartománynak a fajlagosan közölt energia (IMWE) szempontjából az $550 \mathrm{kJg}^{-1}$ - $700 \mathrm{kJg}^{-1}$, a fajlagos mikrohullámú teljesítmény-intenzitás szempontjából az $1,75 \mathrm{Wg}^{-1}-3,5 \mathrm{Wg}^{-1}$ tekinthető.

T3: Az aerob biológiai lebonthatóság jellemzésére fejlesztett biodegradálhatósági index (BDI), és a szervesanyagok vizes fázisban mérhetö koncentrációváltozás jellemzésére fejlesztett oldhatósági index (SLI) alkalmas a mikrohullámú iszapkezelés müveleti paraméterei hatásának objektív vizsgálatára, és azok optimálására. 


\subsection{A mikrohullámú előkezelés hatása az anaerob fermentációra}

A mikrohullámú energiaközlésen alapuló iszap előkezelések során a kutatások a szervesanyagfrakción belül, mind a szénhidrátfrakciók, mind a fehérjék és lipidek oldhatóságának növekedését írják le. Az iszap típusától és a kezelési körülményektől függően az egyes vegyületcsoportok oldhatósági növekménye eltérhet (Appels et al., 2012; Yu et al., 2009). A szénhidrátok és fehérjék, a mikrobiális lebontást lassító iszapszerkezet roncsolás, majd a termikus hatások következtében lejátszódó részleges hidrolízisük miatt, a fajlagosan képződő biogáz térfogatának növekedése mellett a metántermelési folyamatokban a szubsztrát hozzáférést is felgyorsítják. A lipidek sejtmembránokból való felszabadulása, azok magas fajlagos elméleti biogázkihozatali mutatója miatt, elsősorban nem a lebontási folyamat időszükségletére, hanem a kitermelési mutatókra vannak hatással.

\subsubsection{Az illékony komponensek változása}

$\mathrm{Az}$ anaerob folyamatokban keletkező biogáz mennyiségét, illetve a lebontási ütemet az egyes komponensek illékonysága is befolyásolja. Az előkezeléseket követően meghatároztam az iszapminták szárazanyagtartalmán (TS) belül az illékonnyá tehető vegyületek (VS) százalékos arányát is (23. ábra).

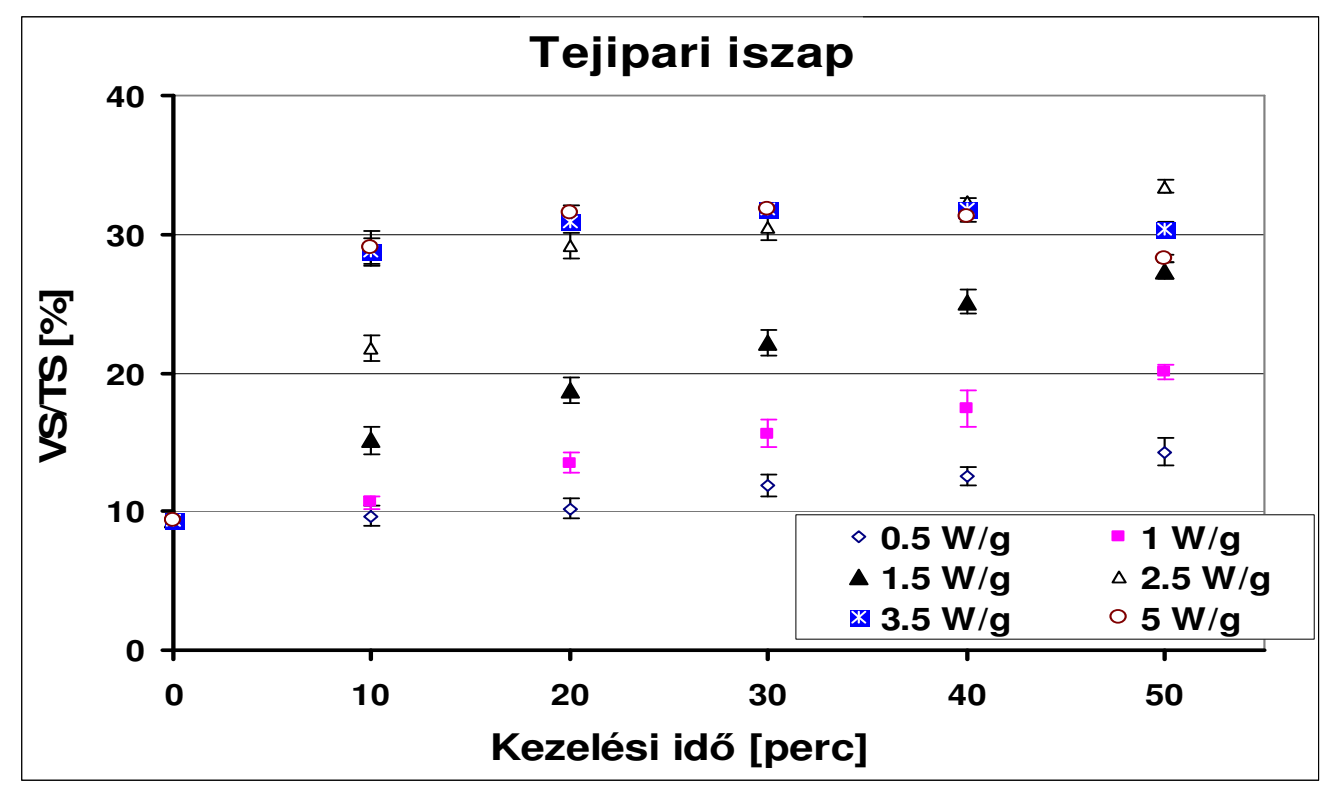

23. ábra. Az illékony vegyületek százalékos aránya a szárazanyagtartalmon belül tejipari iszapnál 
A termikus, és ezen belül a mikrohullámú előkezelési eljárásoknak az illékonyság növekedését okozó hatásairól kommunális eredetü iszapok esetében Dogan and Sanin (2009) már beszámoltak, azonban a mikrohullámú kezelés önálló alkalmazásakor magas véghőmérséklet elérésekor az illékony komponensek kismértékü csökkenését is leírták (Eskicioglu et al., 2008b).

Az élelmiszeripari iszapok esetében a VS/TS arány változása mindkét iszaptípus esetében azonos tendenciát mutatott a BOI/KOI arány változásával (1sd. 13. ábra). A magas teljesítmény-intenzitás (3,5 ill. $5 \mathrm{Wg}^{-1}$ ) hosszú kezelési idővel párosulva az iszap szárazanyagtartalmán belül az illékony vegyületek arányának csökkenését okozta. A VS/TS arány esetében a teljesítmény-intenzitás változásának hatása a húsipari iszap esetében kifejezettebb volt (24. ábra).

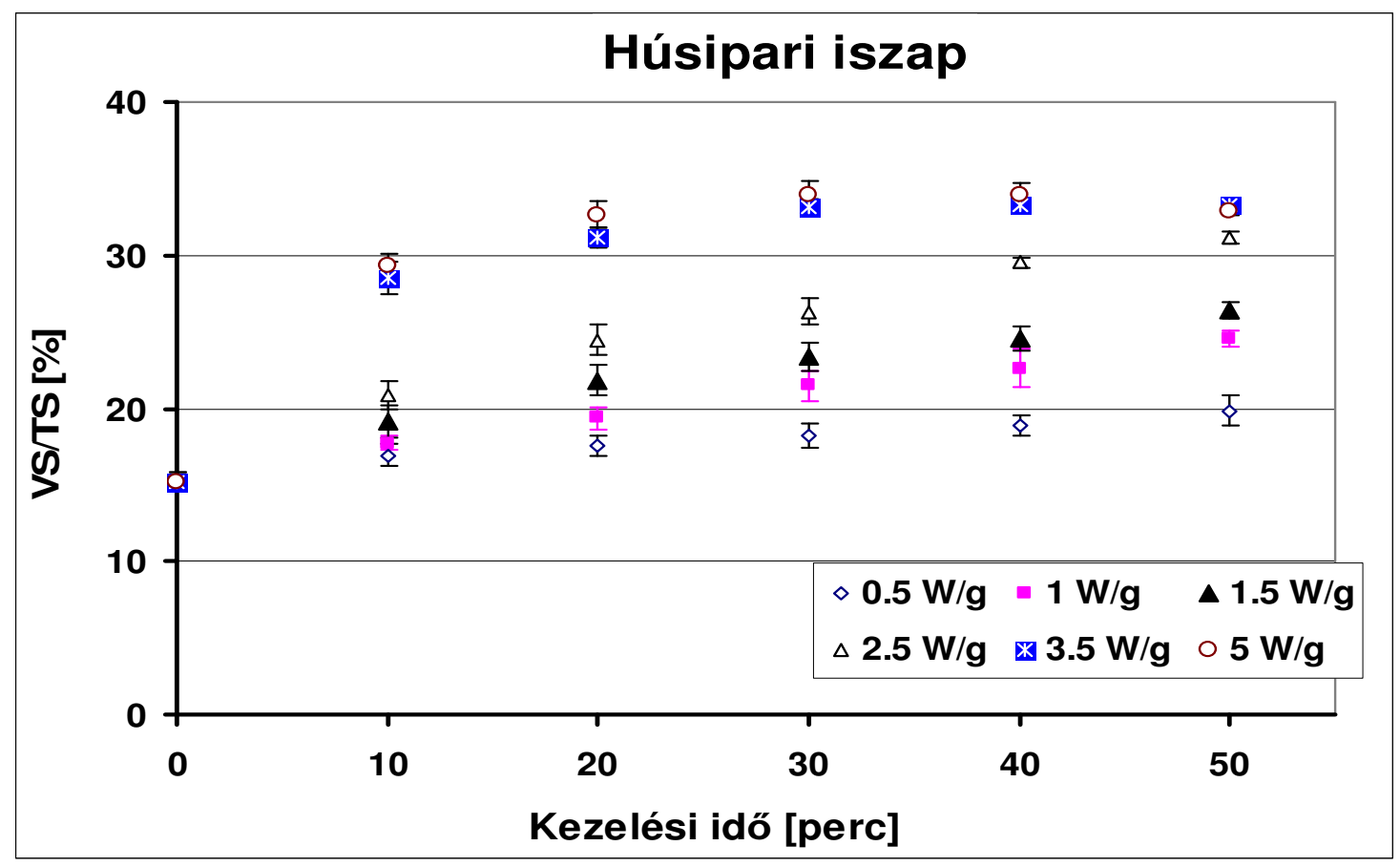

24. ábra. VS/TS változása húsipari iszap esetében 


\subsubsection{Mezofil rothasztási tesztek eredményei}

A mikrohullámú energiaközlés a konzervipari eredetü, magas keményítőtartalmú iszapok elökezelése során is előnyösnek bizonyult a biogáz mennyiségének, és a fermentáció kezdeti szakaszában a biogázképződési sebesség növelésének a szempontjából is. A kontrollként végzett ózonkezeléshez képest a savas kémhatású anyag mikrohullámú kezelését követően a biológiai lebonthatósággal arányos BOI/KOI arány azonos volt, míg az anaerob fermentációban képződő biogáz mennyiséget tekintve a mikrohullám eredményesebbnek bizonyult (25. ábra).

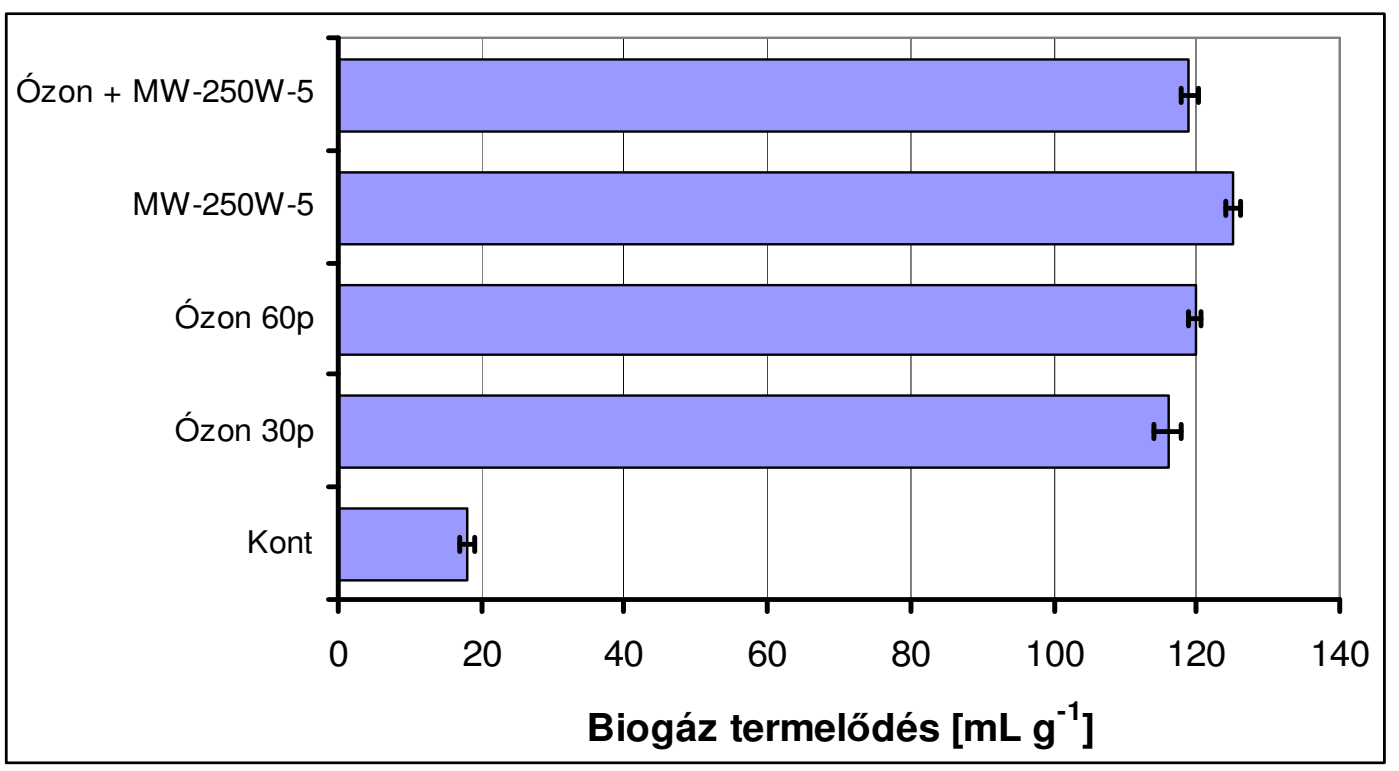

25. ábra. Keményítőtartalmú konzervipari iszap biogáztermelése

A biogázkihozatal mellett a mikrohullámú eljárás legfőbb előnyeként azonban a biogáztermelődés kezdeti sebességének növelése emelhető ki. Az ózonkezeléssel elérhető napi 7,4 $\left[\mathrm{mLg}^{-1}\right]$ biogázképződési ütem, a savas-mikrohullámú előkezelés alkalmazásával $25\left[\mathrm{mLg}^{-1}\right]$ fölé növekedett.

A tejipari és húsipari iszapok három párhuzamosban végzett mezofil hőmérséklettartományú rothaszási tesztjeinek eredményei alapján megállapítható volt, hogy az egységnyi tömegü iszapra számított fajlagos biogázproduktum a kezeletlen mintához képest a mikrohullámú elökezelésekkel növelhető volt, és a mikrohullámmal kezelt iszapminták biogázkihozatali mutatójának növekménye jelentősen meghaladta a hagyományos termikus előkezelésekkel elérhetőeket (26. ábra). 


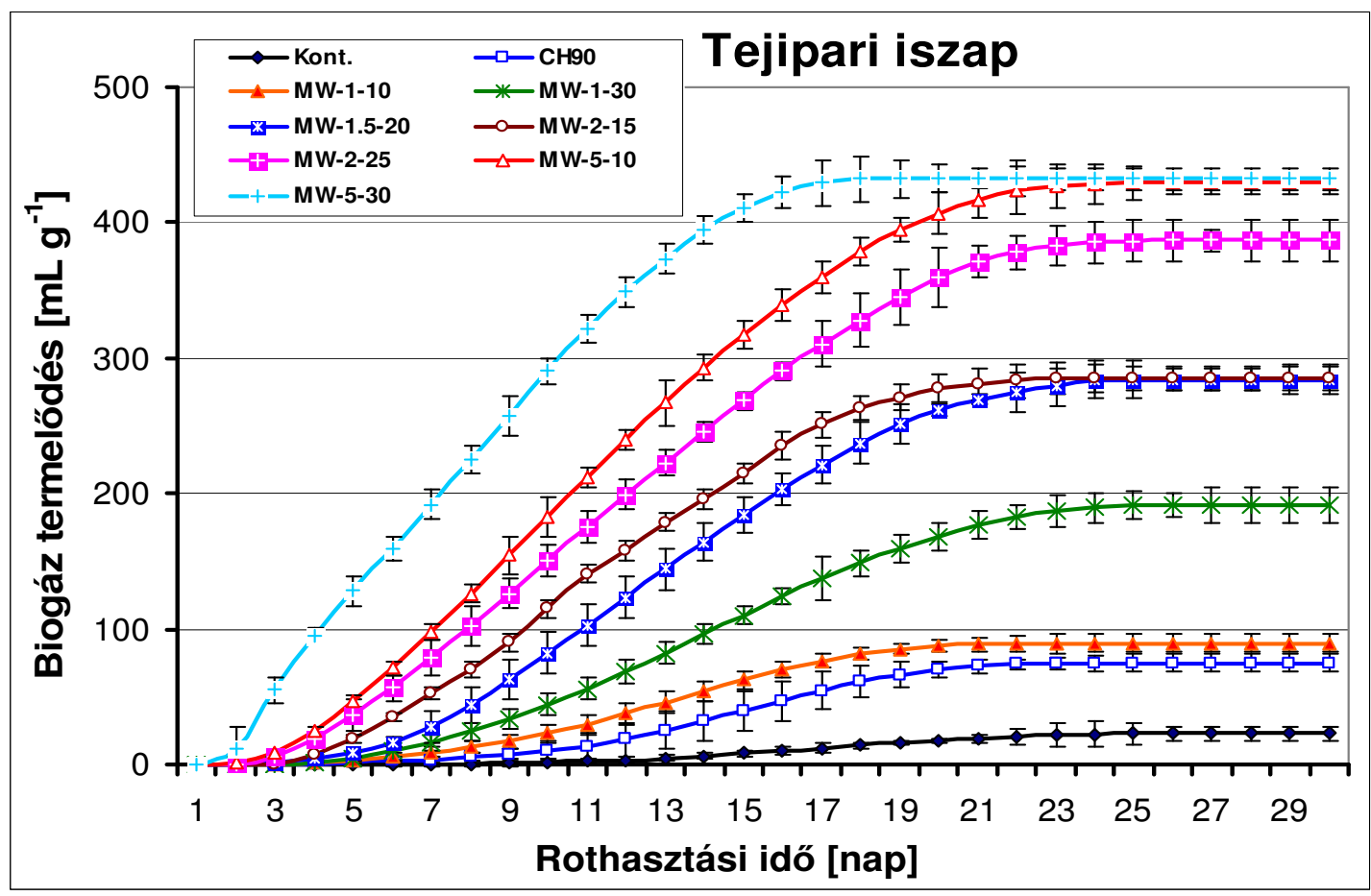

26. ábra. Tejipari iszap kummulatív biogáztermelési görbéi

$\mathrm{Az}$ aerob lebontás jellemzésére kifejleszett biodegradálhatósági index esetében leírtaktól eltérően, a lebontást végző mikróbaközösségek összetételének, illetve az egyes lebontási folyamatokban lejátszódó biokémiai folyamatok különbözősége, valamint a meghatározás során alkalmazott lebontási idő jelentősnek tekinthető eltérése miatt, az anaerob lebonthatóság mértékére jellemző biogáz térfogat, a kummulatív biogáztermelési görbék alapján, az MWPL növelésével nem mutatott csökkenő tendenciát. A BDI szempontjából optimális teljesítmény-intenzitásnál intenzívebb előkezelést alkalmazva a fajlagos biogázkihozatali mutató tovább növekedett. Az élelmiszeripari iszapoknál a mikrohullámú teljesítmény-intenzitás növelésének a biogázfermentációra gyakorolt előnyös hatása a szakirodalomban a kommunális iszapok esetében leírt egyes tapasztalatoknak ellentmond (Eskicioglu et al., 2007), míg más kutatási eredmények megállapításaival egyezik (Toreci et al., 2009; Mudhoo et al., 2012).

Az időegység alatti biogázproduktumot, vagyis a biogázképződés ütemét tekintve a mikrohullámmal előkezelt iszap rothaszthatósága a kontrollmintához képest jobb volt. Mind az anaerob lebontási folyamat során elérhető maximális biogázképződési sebességet, mind az anaerob elbontáshoz szükséges időtartamot, mind a biogázképződés megindulásához szükséges kezdeti adaptációs időt tekintve a mikrohullámú kezelés 
előnyösebbnek bizonyult a termikus előkezeléshez képest. $\mathrm{Az} 5 \mathrm{Wg}^{-1}$ fajlagos teljesítményintenzitással 10 és 30 perc időtartamig kezelt húsipari iszap kummulatív biogázproduktuma között nem mutatkozott különbség, azonban a gáztermelődési ütemet tekintve a kezelési idő növelése a maximális gáztermelődési sebesség további növekedése, és a lebontási folyamat időszükségletének csökkentése miatt előnyösebbnek bizonyult (27. ábra).

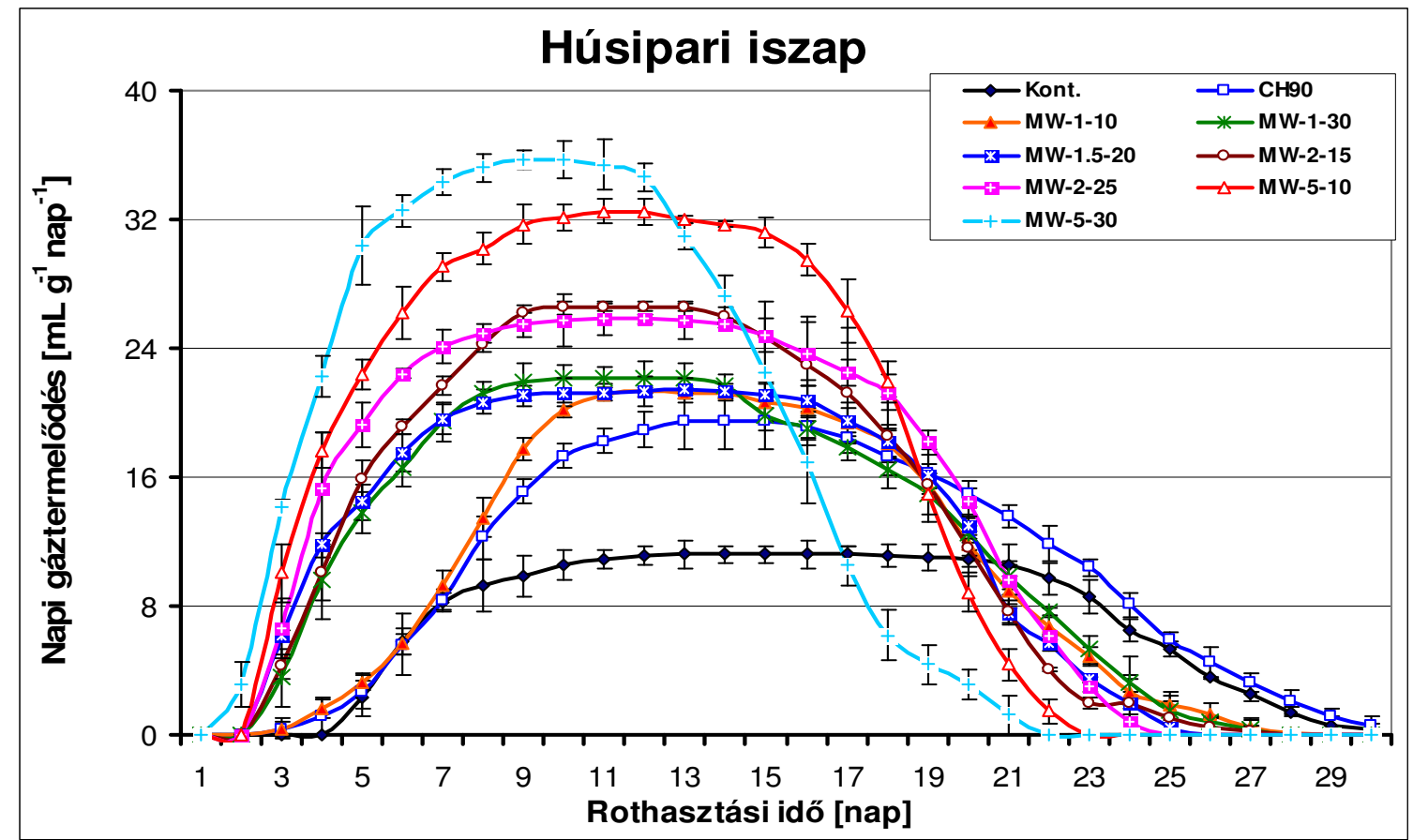

27. ábra. Húsipari iszap biogáztermelődési üteme

A kétféle vizsgált szennyvíziszap esetében a 11. összefoglaló táblázatban megadtam az egyes előkezelések után rothasztott iszapok anaerob fermentációs hatékonysága szempontjából meghatározó paramétereket. A tömegegységre vonatkoztatott, fajlagos biogázkihozatali mutató a kummulatív görbék telítési értékeként, illetve a napi lebomlási ütemet leíró gáztermelődési sebességgörbék integrálásával kapható meg. Emellett szerepeltetem a biogázképződés megindulásához szükséges, az anaerob lebontás teljes folyamatidejét nagyban befolyásoló kezdeti LAG periódus hosszát is, amely a rothasztási tesztek mérési eredményéből volt meghatározható. A kummulatív biogázkihozatali, vagy másnéven biogáztermelődési görbék a kezdeti adaptációs szakasz után egy lienáris felfutási szakasszal jellemezhetőek. A különböző előkezeléseket követően tapasztalt eltérő adaptációs periódus, és a telítési szakaszok kezelések okozta eltolódásai miatt valamennyi 
esetben a görbék lineáris szakaszainak öt napos periódusára egyeneseket illesztettem, amelyek iránytangense megadja az átlagos napi gáztermelődési sebességet.

A biogázkihozatal 50\%-ának eléréséhez $(Y=0,5)$ tartozó időszükségletet, amely egyben a szervesanyagok maximális kirothaszthatóságának 50\%-ához szükséges időtartam is, a napi gáztermelődési görbékből számítottam. Amennyiben azok normál eloszlásúnak voltak tekinthetőek a mediánhoz tartozó időpontot az MS Excel Solver bővítményével határoztam meg, amely egyben a maximális gáztermelődési sebességhez tartozó időpont, vagyis a gáztermelődési „haranggörbék” maximuma. Amennyiben statiszikai módszerekkel kimutathatóan a mérési adatok nem követték a normál eloszlást, akkor a mérési időpontokhoz tartozó értékek ismeretében manuálisan határoztam meg a paramétert.

11. táblázat. A biogázfermentációs kísérletek összefoglaló táblázata

\begin{tabular}{|c|c|c|c|c|c|c|c|c|}
\hline \multicolumn{4}{|c|}{ Tejipari iszap } & \multirow{2}{*}{$\begin{array}{c}\text { Kezelés } \\
\text { típusa }\end{array}$} & \multicolumn{4}{|c|}{ Húsipari iszap } \\
\hline $\begin{array}{l}\text { LAG } \\
\text { szakasz } \\
\text { [nap] }\end{array}$ & $\begin{array}{c}\text { Átl. } \\
\text { gázterm } \\
\text { [mL/nap] }\end{array}$ & $\begin{array}{l}\text { Biogáz } \\
\text { kihoz. } \\
{\left[\mathrm{mL} \mathrm{g}^{-1}\right]}\end{array}$ & $\begin{array}{c}\text { Roth. idő } \\
(\mathrm{Y}=0.5) \\
\text { [nap] }\end{array}$ & & $\begin{array}{c}\text { LAG } \\
\text { szakasz } \\
\text { [nap] }\end{array}$ & $\begin{array}{c}\text { Átl. } \\
\text { gázterm } \\
\text { [mL/nap] }\end{array}$ & $\begin{array}{c}\text { Biogáz } \\
\text { kihoz }^{-1} \\
{\left[\mathrm{~mL} \mathrm{~g}^{-1}\right]}\end{array}$ & $\begin{array}{c}\text { Roth. idő } \\
(Y=0.5) \\
\text { [nap] }\end{array}$ \\
\hline 7,2 & 0,883 & 23,2 & 16,63 & Kont. & 4,5 & 7,682 & 206,3 & 15,18 \\
\hline 6,4 & 1,872 & 68,7 & 14,42 & $\mathrm{CH}-80$ & 4,2 & 8,291 & 224,6 & 13,03 \\
\hline 5,2 & 2,074 & 78,1 & 13,48 & CH-90 & 3,6 & 8,342 & 293,9 & 11,98 \\
\hline 5,4 & 3,179 & 89,7 & 13,96 & MW-1-10 & 3,2 & 9,407 & 289 & 14,53 \\
\hline 4,6 & 7,315 & 192,1 & 13,26 & $M W-1-30$ & 2,6 & 13,374 & 345,9 & 12,68 \\
\hline 3,8 & 13,086 & 351,6 & 12,43 & $M W-1-50$ & 2,4 & 15,105 & 367,2 & 12,18 \\
\hline 4,2 & 8,377 & 284,3 & 13,01 & MW-1.5-20 & 2,4 & 16,428 & 342,5 & 12,23 \\
\hline 3,4 & 13,388 & 285,1 & 11,89 & MW-2-15 & 2 & 17,523 & 385,6 & 11,76 \\
\hline 3,2 & 15,819 & 386,8 & 11,39 & MW-2-25 & 1,6 & 20,618 & 411,1 & 11,47 \\
\hline 2 & 15,917 & 429,2 & 10,78 & MW-5-10 & 1,8 & 20,987 & 450,7 & 10,81 \\
\hline 1,4 & 21,841 & 432,5 & 7,85 & $M W-5-30$ & 1,2 & 22,017 & 446,5 & 9,36 \\
\hline
\end{tabular}

Az anaerob fermentáció szempontjából leghatékonyabbnak tekinthető mikrohullámú előkezelés alkalmazásával a tejipari iszap esetében, a kezeletlen iszaphoz képest, közel 19szeres, húsipari iszapnál kb. 1,2-szeres térfogatú biogáz nyerhető. A tejipari iszap rothaszthatósága még az aerob lebonthatóságnál is nagyobb mértékben gátoltnak tekinthető a húsipari iszaphoz viszonyítva, ennek megfelelően a tejipari iszap mikrohullámú előkezelése méginkább indokolt. 
A maximális biogázkihozatal 50\%-ának eléréséhez szükséges időt figyelembe véve a fajlagos teljesítmény-intenzitást magas értéknek választva érhető el a termikus előkezelésekhez képest kedvezőbb eredmény. Az alacsony teljesítmény-intenzitású kezelések a termikus kezelésekhez képest nem tekinthetőek előnyösebbnek, rövidebb idejü kezeléseket alkalmazva a biogáz kihozatal is közel azonos. A tényleges biogáztermelődés kezdetéhez szükséges idő a mikrohullámú előkezeléssel tejipari iszapnál akár 80\%-al, húsipari iszapnál kb. 75\%-al csökkenthetö. A LAG fázisnak a mikrohullámú kezelés hatására bekövetkező kb. 40\%-os csökkenését kommunális iszapok esetében is tapasztalták (Mudhoo et al., 2012).

Szintén kommunális eredetü, biológiai tisztítóból elvezetett fölösiszapok esetében ismert, hogy a mikrohullámú kezelési teljesítmény hatást gyakorolhat a gázképződési sebességre (Kennedy et al., 2007). Az élelmiszeripari iszapok esetében a saját kísérleti eredményeimből megállapítottam, hogy az átlagos gáztermelődési sebességnek a teljesítményszinttől és a kezelési időtől való függését az iszap típusa is befolyásolja. Míg a húsipari iszap esetében az $1,5 \mathrm{Wg}^{-1} 20$ perces kezelés az $1 \mathrm{Wg}^{-1} 50$ perces kezeléshez képest a gáztermelődési ütemet fokozza, addig tejipari iszap kezelésekor ugyanezen kezelési körülmények összehasonlításakor jelentős - kb. 64\%-os - csökkenést tapasztaltam.

Az anyaggal közölt fajlagos energiát tekintve az $1,5 \mathrm{Wg}^{-1} 20$ perces és a $2 \mathrm{Wg}^{-1} 15$ perces kezelés azonosnak tekinthető, azonban a 11. táblázat alapján látható, hogy a húsipari iszapnál a biogázkitermelési mutatóban kb 12\%-os, míg a tejipari iszap esetén pedig a gáztermelődési sebességben közel 60\%-os különbség van. A biogáz kihozatali eredmények esetében azonban meg kell jegyezni, hogy ha a képződő biogáz térfogatát nem a rothasztásra kerülő minta szárazanyagtartalmára, hanem az egységnyi lebontott szervesanyagra vonatkoztatjuk, akkor az anaerob fermentációban a szervesanyag hasznosításra vonatkozóan nyerhetünk információkat.

A két mintánál a KOI egységben mért szervesanyag fogyasztásra eső gáztérfogatot kiszámítva látható, hogy míg a húsipari iszap esetében az anyaggal közölt energia alapján azonosnak tekinthető kezelések a szervesanyagfogyásra eső biogáz mennyiség alapján azonos hatásfokkal fermentálhatóak, addig a tejipari iszapot mgasabb teljesítményszinten kezelve a szervesanyag biogázzá való transzformációjának hatásfoka romlik (28. ábra). 


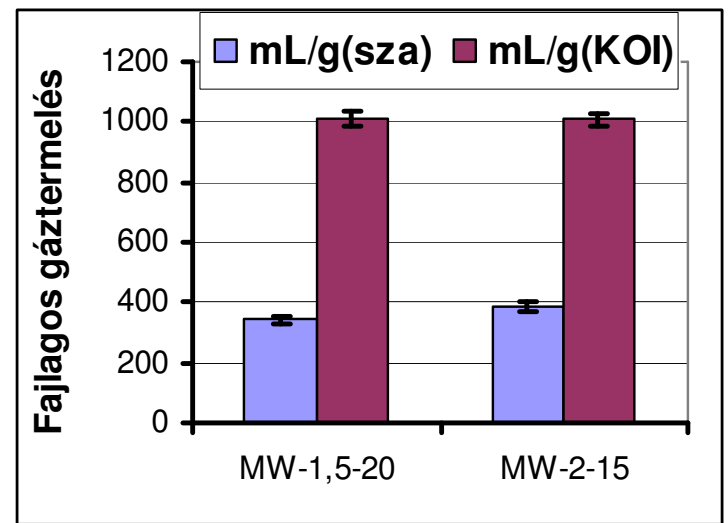

a)

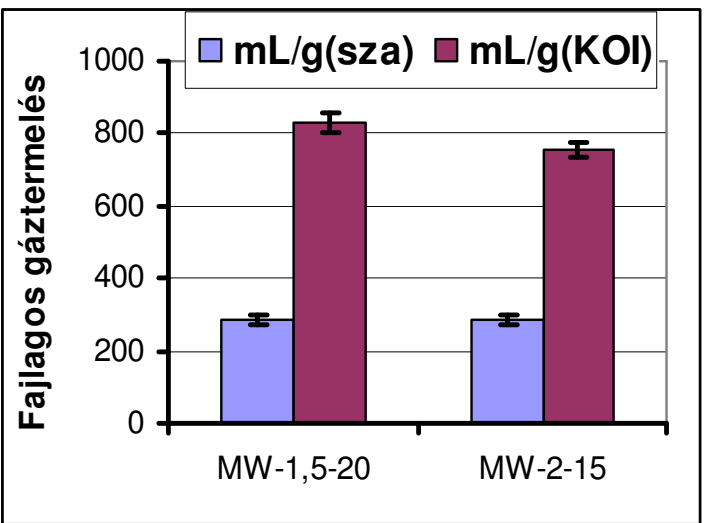

b)

28. ábra. Húsipari (a) és tejipari (b) iszap biogázkihozatali mutatói

A közölt energiát tekintve szintén ekvivalens $2 \mathrm{Wg}^{-1} 25$ perces és $5 \mathrm{Wg}^{-1} 10$ perces kezelések esetében a gáztermelödési sebességek közötti különség csekély, azonban a magasabb teljesítmény-intenzitás alkalmazásakor a tejipari iszapnál 11\%-os biogáztöbblet volt.

A gáztermelődési sebesség a szervesanyagok mikroorganizmusok számára biztosított hozzéférhetőségével is összefügg. A szubsztrát-hasznosításbeli különbségek a fermentáció kezdeti szakaszában az élőcsíraszám változással, indirekt módon, is nyomonkövethetőek. A kezelések után meghatározott csíraszám alapján látható, hogy az egyes előkezelések az iszap eredeti élőmikroorganizmus számát milyen mértékben képesek elpusztítani.

Az oltóiszap adagolást megelőző csíraszámcsökkenés az adagolt anaerob mikroorganizmusokkal a szubsztrátért való kezdeti versenyt csökkenti. Az élőcsíraszám változási dinamikája, azonos körülmények és oltóiszap alkalmazásakor, a szubsztrátként hasznosítható vegyületek koncentrációja és oldhatósági viszonyai által is meghatározott. A kezelések után, illetve a beoltást követő 5-10 napos idő intervallumban a csíraszám változása, valamint a gáztermelődés változási dinamikája azonos tendenciát mutatott a vizsgált iszap esetében (29. ábra). 


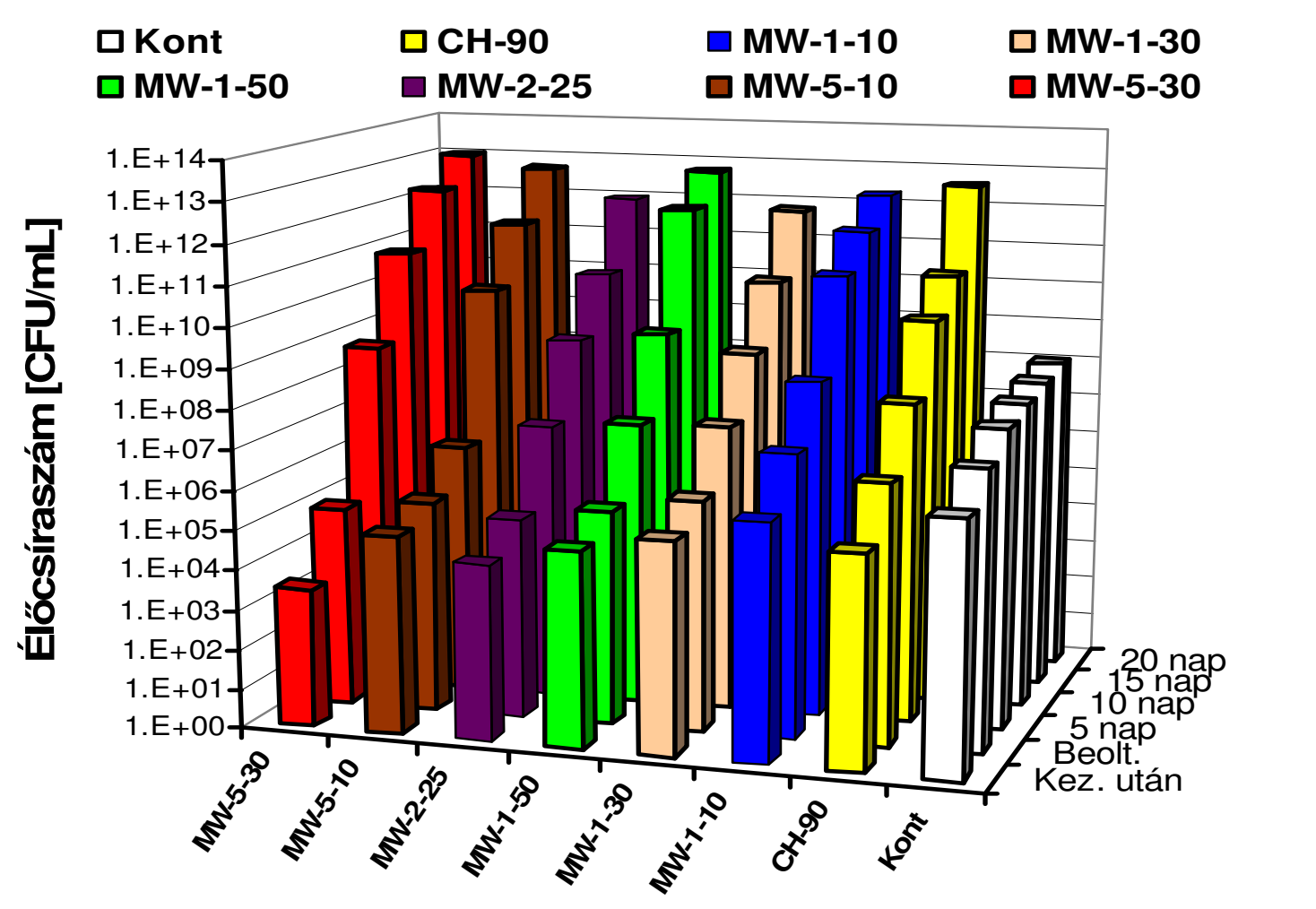

29. ábra. Az élőcsíraszám változása húsipari iszap rothasztásakor

Az iszapból képződő biogáz teljes térfogatának ismerete mellett, a további energetikai hasznosítás szempontjából a metán, mint éghető és magas fütőértékü komponens, arányának ismerete is lényeges tényező az egyes előkezelések hatékonyságának megítélése szempontjából. A mikrohullámú iszapkondicionálás a kommunális iszapok esetében a kezeletlen alapanyaghoz képest növeli az egységnyi rothasztott iszap tömegre vonatkoztatott metán kihozatali mutatót (Kuglarz et al., 2013).

Emellet meg kell jegyezni, hogy a szervesanyag feltárás szempontjából hatékonyabbnak tekinthető oxidációs eljárásokkal kombinált mikrohullámú kezelések egyik legfőbb hátránya, hogy a fajlagos metántermelődés alacsonyabb, mint a mikrohullám önálló előkezelésként való alkalmazásakor (Eskicioglu et al., 2008a). A lúgos-termikus kezelésekkel összehasonlítva a metánprodukció szempontjából a mikrohullámú kezelés közel azonos hatékonyságú, a kezeletlen iszaphoz viszonyítva kb. 11\%-os növekményt találtak, az erősen lúgos kémhatású mikrohullámú hevítéssel a képződő metán mennyisége kb. 20\%-al növelhető (Dogan and Sanin, 2009). 
Alacsony szárazanyagtartalmú, kommunális eredetü iszapok mikrohullámú kondicionálása esetében a kezelések során alkalmazott mikrohullámú teljesítmény hatását Kuglarz et al. (2013) nem találták szignifikánsnak, amellett, hogy a mikrohullámú előkezeléssel a kezeletlen iszaphoz képest kb. 40\%-al nőtt a metánkitermelés, és az azonos hőmérsékleten kivitelezett hagyományos hőkezelés a mikrohullámú kezeléshez képest kb. 50\%-al alacsonyabb kihozatali mutatót eredményezett.

Mindezeket figyelembe véve, az élelmiszeripari eredetü iszapok esetében is szükségesnek tartottam a biogázon belül a metán komponens arányának vizsgálatát is. A mérési eredményeim a vizsgált élelmiszeripari iszapok esetében is igazolták a mikrohullámnak az anaerob fermentáció alatti metánképződésre gyakorolt előnyös hatását, amelnyek mértéke meghaladta a kontroll kezelésként alkalmazott termikus kezelések hatásfokát.

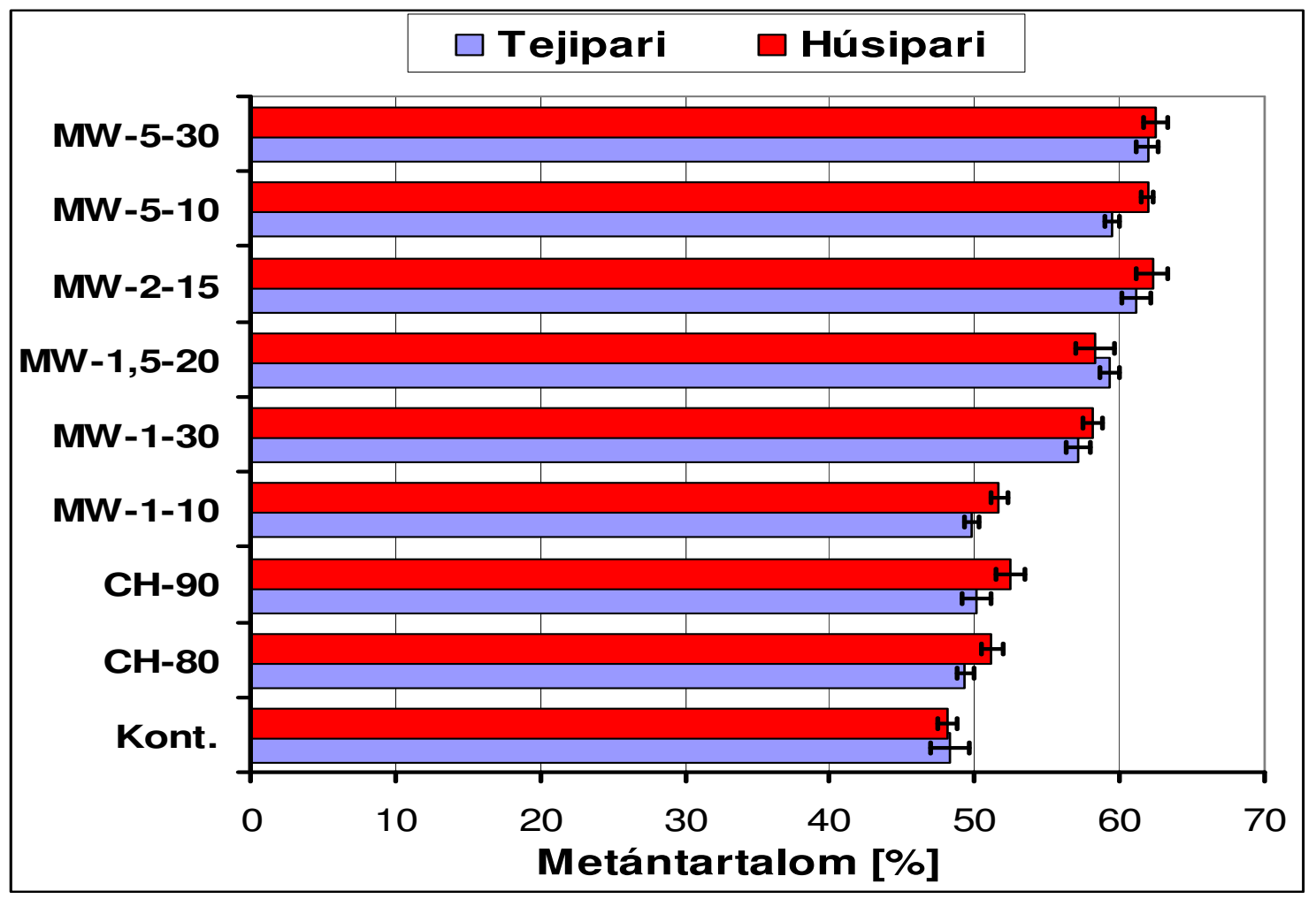

30. ábra. A biogáz metántartalmának változásai 
Mind a tejipari, mind a húsipari iszapból képződő biogáz a 30 napos fermentációs időszak végén $\mathrm{kb}$. 48\%-os metántartalommal rendelkezett, ami a $2 \mathrm{Wg}^{-1}$, illetve ennél nagyobb teljesítmény-intenzitású előkezeléssel $60 \%$ fölé volt növelhető (30. ábra).

A teljesítmény-intenzitás $2 \mathrm{Wg}^{-1}$ értéket meghaladó tartománya, illetve az adott teljesítményszinten a kezelési idő 10 perc fölé növelése a fajlagos biogázprodukciót növelte, azonban a metán részarányának változása az azonos szórások feltételének teljesülése miatt alkalmazott kétmintás t-próba eredményei alapján már nem tekinthető szignifikánsnak.

T4: A mikrohullámú energiaközlésen alapuló elókezelés az anaerob fermenteció során a biogázkitermelési mutatót az alkalmazott fajlagos kezelési teljesitmény-intenzitástól függö mértékben javítja, továbbá a képzödö biogáz metán tartalmát növeli élelmiszeripari iszapok esetében.

T5: A mikrohullámú iszapkondicionálási eljárás az élelmiszeripari iszapok anaerob fermentációs folyamatban való hasznosítása során alkalmas a rothasztási idöszüikséglet hatékony csökkentésére, továbbá az anaerob lebomlás ütemének felgyorsítása révén a biogáz képzödési sebességének növelésére. 


\subsubsection{A rothasztást megelőző mikrohullámú kezelések energia- hasznosulási mutatói}

A mikrohullámú energiaközlés az anaerob fermentációs folyamatban képződő biogáz térfogata, és ezen belül a metán komponens aránya szempontjából a vizsgált élelmiszeripari iszapok esetében előnyösnek bizonyult. Azonban a mikrohullámú eljárások hatékonyságának elemzésekor figyelelmbe kell venni a folyamat során befektetett energiának a rothaszthatóság szempontjából értelmezett megtérülését is.

Az anaerob fermentáció előtt alkalmazott mikrohullámú kezelések energihasznosulásának jellemzését a [35] összefüggés felhasználásával végeztem.

$$
\Delta E=\frac{\left(q_{\text {égés }} \cdot V_{C H_{4}}\right)-\left(P_{\text {mag }} \cdot \tau_{\text {kez }}\right)}{m_{\text {iszap }}} \quad\left[J g^{-1}\right]
$$

A kezelések alkalmazásának betudható „,nettó fajlagos energia növekményt,, $(\Delta \mathrm{E})$ az azok hatására mérhető többlet biogáz energiatartalmának, illetve a kezelés során beállított magnetronteljesítmény $\left(\mathrm{P}_{\mathrm{mag}}\right)$ és idő $(\tau)$ szorzatának különbségeként értelmeztem, egységnyi tömegü kezelt anyagra $\left(\mathrm{m}_{\mathrm{iszap}}\right)$ vonatkoztatva.

A szakirodalom által gyakran használt átlagos fajlagos biogáz energiatartalom helyett, a saját kísérleteimben igazolt változó metán arány miatt, a metán térfogatának $\left(\mathrm{V}_{\mathrm{CH} 4}\right)$ és égésghőjének (qégés) szorzataként számítottam azt.

A 8. táblázatban leírt müveleti paraméterek megfelelő szintjeinek beállításával kezelt, majd mezofil hőmérséklettartomány biztosítása mellet rothasztott iszap minták esetében meghatározott $\Delta \mathrm{E}$ értékek felhasználásával az SLI és BDI paraméterek esetében leírtakkal azonos módon vizsgáltam az egyes változók hatásának szignifikanciáját, majd a nem szignifikánsú változók és interakciók mellőzésével a [36] regressziós egyenletet nyertem (az egyenletben a $\mathrm{X}_{1}$ és $\mathrm{X}_{2}$ változó a [33] összefüggés jelölésével azonos).

$$
\Delta E=326.12-27.29 X_{1}-237.74 X_{2}-4.017 X_{1}^{2}-470.79 X_{2}^{2}-385.9 X_{1} X_{2} \quad\left[J g^{-1}\right]
$$

A matematikai modell alapján a $\Delta \mathrm{E}$ kontrollparaméter esetében is megállapítható volt, hogy mindkét változó meghatározza a folyamat energiahatékonyságát, illeve azok kölcsönhatása is befolyásoló erővel bír. 
Az alkotott modell érvényességét varianciaanalízissel vizsgáltam, amelynek az eredményét a 12. táblázat foglalja össze.

12. táblázat. Varianciaanalízis eredménye a $\Delta \mathrm{E}$-re vonatkozóan

\begin{tabular}{|l|c|c|c|c|c|c|c|}
\hline & DF & SS & MS & F & $\mathrm{F}_{\text {krit }}$ & $p$ & SD \\
\hline Alapadatok & 18 & 0,4632 & 0,0182 & & & & 0,0995 \\
\hline $\begin{array}{l}\text { Modellel } \\
\text { becsült }\end{array}$ & 5 & 0,3914 & 0,2317 & 845,36 & 3,02 & 0,0001 & 0,1532 \\
\hline Maradvány & 13 & 0,0045 & 0,0010 & & & & 0,0021 \\
\hline $\begin{array}{l}\text { Illeszkedési } \\
\text { hiba }\end{array}$ & 4 & 0,0032 & 0,0001 & 8,26 & 3,63 & 0,314 & 0,0019 \\
\hline Hiba & 9 & 0,0006 & 0,0002 & & & & 0,0038 \\
\hline
\end{tabular}

A $\Delta \mathrm{E}$ paraméter becslésére alkotott modell esetében megállapítható, hogy a modell korrelációs együtthatója és jósági tényezője rosszabb $\left(\mathrm{R}^{2}=0,851 ; \mathrm{Q}^{2}=0,793\right)$, mint a SLI és BDI esetében volt.

A modell felhasználásával alkotott válaszfelület kétdimenziós metszetét (31. ábra) tekintve azonban megállapítható, hogy a mikrohullámú energiaközlésen alapuló iszap előkezelés, a szervesanyagok oldhatóságának növelése, az aerob biológiai lebonthatóság fokozása, illetve az anaerob fermentációs folyamatban képződő biogáz mennyiségének növelése és a lebontási ütem felgyorsítása mellett, a nagy energiaigény ellenére, a vizsgált élelmiszeripari iszapok esetében, a müveleti paraméterek megfelelő megválasztásával a kezelések energiamegtérülési mutatója szempontjából is hatékonynak tekinthető.

A mikrohullámú előkezelés, az annak alkalmazása során az anyaggal közölt energia, illetve a hatására keletkező biogáztöbblet alapján a 600-750 kJg ${ }^{-1}$ IMWE, illetve az 2,5-3,0 $\mathrm{Wg}^{-1}$ MWPL paraméter tartományokon belül tekinthető energetikailag a legkedvezőbbnek. 


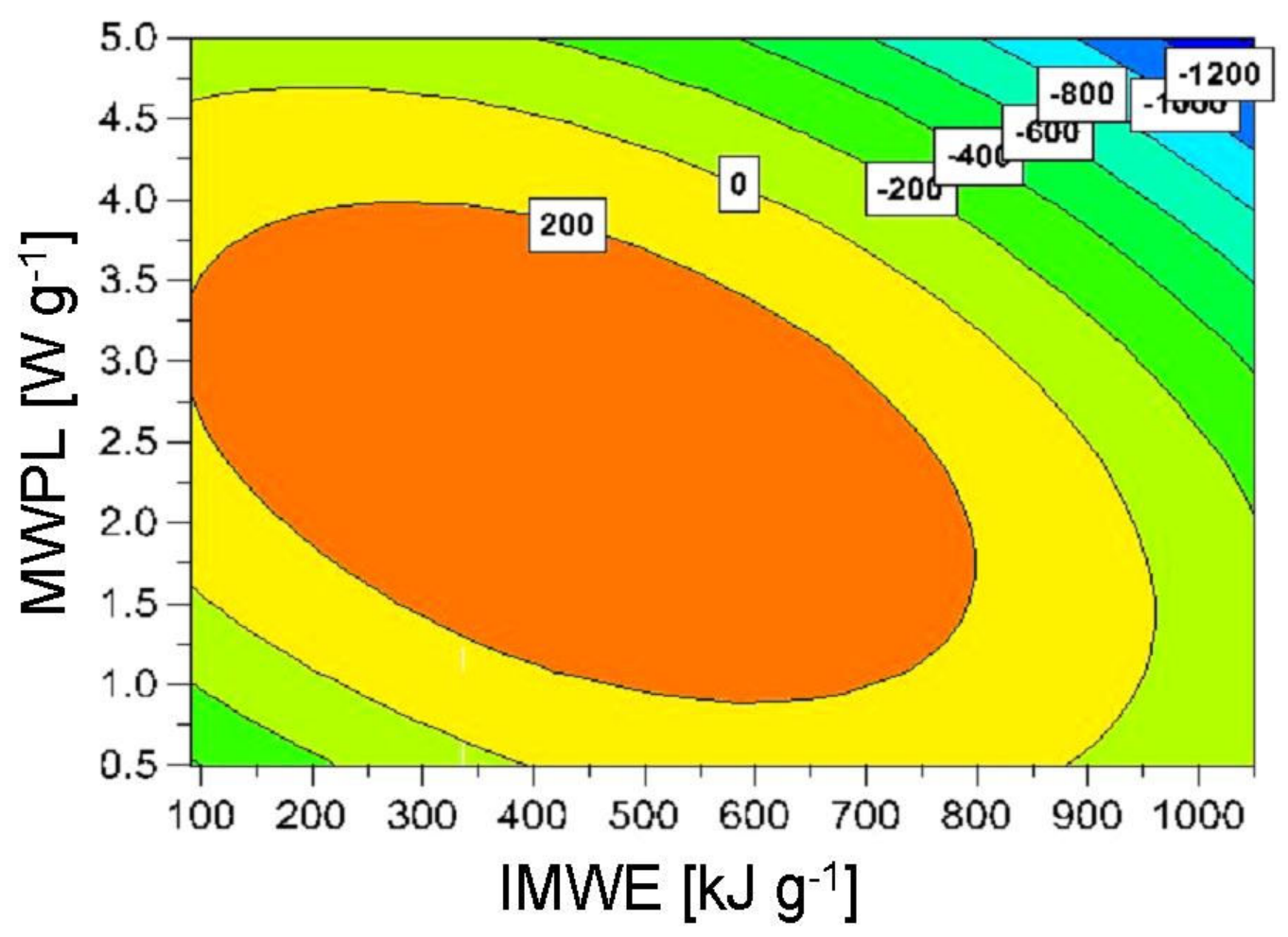

31 ábra. $\Delta \mathrm{E}$ paraméterre alkotott modell által generált válaszfelület $2 \mathrm{D}$ metszete

A viszonylag széles optimum tartományon belül az alkalmazásra javasolható kezelési paraméterek, illetve paraméter-tartományok megválasztását az esetleges léptéknövelés során a kezelési kapacitásigény mértéke és ennek fluktuációja, továbbá a teljesítményintenzitás miatt a tényleges hálózati villamos teljesítményigény és a nagyteljesítményü kezelőberendezések hozzáférhetősége, illetve ezek ára is befolyásolja.

T6: A mikrohullámú iszap kondicionálási eljárás esetében a biogázproduktum, és annak metántartalma alapján meghatározott optimális müveleti paramétertartományok nem azonosak az energetikai szempontú optimálás során meghatározottal. A rothasztást megelezö mikrohullámú elókezelés hatékonyságának elemzésekor az energiahasznosulási mutató alkalmazása szükséges. 


\subsection{Az iszap szervesanyag frakciójában bekövetkező változások és a dielektromos jellemzők összefüggése}

A mikrohullámú sugárzás terjedését, valamint a mikrohullámú hőkeltés hatásfokát, a kezelt anyag dielektromos jellemzői nagymértékben meghatározzák. A dielektromos jellemzők értékei, illetve ezeknek a mikrohullámú térben, a különböző célú kezelések közben bekövetkező változásai, az anyag összetételétől és szerkezetétől, a komponensek kémiai tulajdonságaitól, a változó polaritású elektromágneses sugárzás frekvenciájától, illetve a sugárzás hatására esetlegesen lejátszódó kémiai és fizikai változásoktól, továbbá a hőmérséklettől egyaránt függnek (Nelson, 2010). Abban az esetben, ha a mikrohullámú energiaközlést éppen az anyag szerkezeti tulajdonságainak megváltoztatása, vagy kémiai reakciók feltételeinek biztosítása céljából alkalmazzák, a dielektromos jellemzők - mint a dielektromos állandó, vagy a dielektromos veszteségi tényező - értékei nem tekinthetőek állandónak. Az iszapoknak a magas víztartalmuk mellett, a víz kötésformáit befolyásoló intracelluláris és intercelluláris szerkezetük is befolyásolja a dielektromos jellemzőik értékeit. A kezelések hatására az iszappelyhek szerkezetének felbomlásával, illetve a sejthártyák felszakadásával a szabad víz aránya növekszik. Ezen kívül figyelembe kell venni, hogy a vízben oldott vegyületek koncentrációváltozásai szintén befolyásolják az energia elnyelődését, illetve az ezzel összefüggő dielektromos és egyéb anyagi jellemzőket is.

Mivel az előző fejezetekben bemutatott kísérleti eredményeim igazolták, hogy az élelmiszeripari iszapokban a mikrohullámú kezelés hatására szerkezeti változások mennek végbe, vizsgáltam az ezekkel összefüggő szervesanyag oldhatóság (SCOD/TCOD), illetve a szervesanyagon belüli biológiailag lebontható komponens-arány (BOI/KOI) paramétereknek a dielektromos jellemzőkre gyakorolt esetelges hatásait, illetve a paramétercsoportok összefüggéseit is.

Mivel az általam vizsgáltakhoz hasonló szerkezetủ és tulajdonságú iszapok dielektromos jellemzőire vonatkozóan szakirodalmi adatok nem állnak rendelkezésre, a húsipari eredetű iszappal végzett kísérletsorozat során, azok magas nedvességtartalma miatt, a dielektromos jellemzők esetében a vízhez hasonló viselkedés volt várható a hőmérséklet változásának függvényében. A szakirodalmi eredmények alapján a dipólusos vízmolekulák alkotta rendszerben, az általam is használt frekvenciatartományban, a dielektromos állandó és a 
dielektromos veszteségi tényező értéke a hőmérséklet növelésével csökken. Apoláris molekulákat tartalmazó rendszerkben a veszteségi tényező hőmérsékletfüggése ezzel ellentétes tendenciával jellemezhető (de los Santos, et al., 2003).

A kísérleteket elvégeztem a rendelkezésemre álló húsipari eredetű szenyvíziszappal (ISZ1; TS=9,7 m/m\%), illetve víztelenített húsipari iszap adagolásával megnövelt szárazanyagtartalmú iszappal is (ISZ2, TS=14,7 m/m\%). A kísérletek során meghatározott dielektromos állandó $(\varepsilon ’)$ és a dielektromos veszteségi tényező ( $\left.\varepsilon^{\prime \prime}\right)$ hőmérsékletfüggése az irodalmi adatokban leírt tendenciákkal nem egyezett. Az eredeti szennyvíziszap (ISZ1) dielektromos állandója $20-50^{\circ} \mathrm{C}$ hőmérséklettartományban csökkent, majd kismértékben emelkedett (32. ábra), míg a dielektromos veszteségi tényező kismértékű csökkenést követően $30-60^{\circ} \mathrm{C}$ tartományban nem mutatott szignifikáns változást, majd ezt követően a hőmérséklet emelkedésével ugrásszerüen növekedett az értéke (33. ábra).

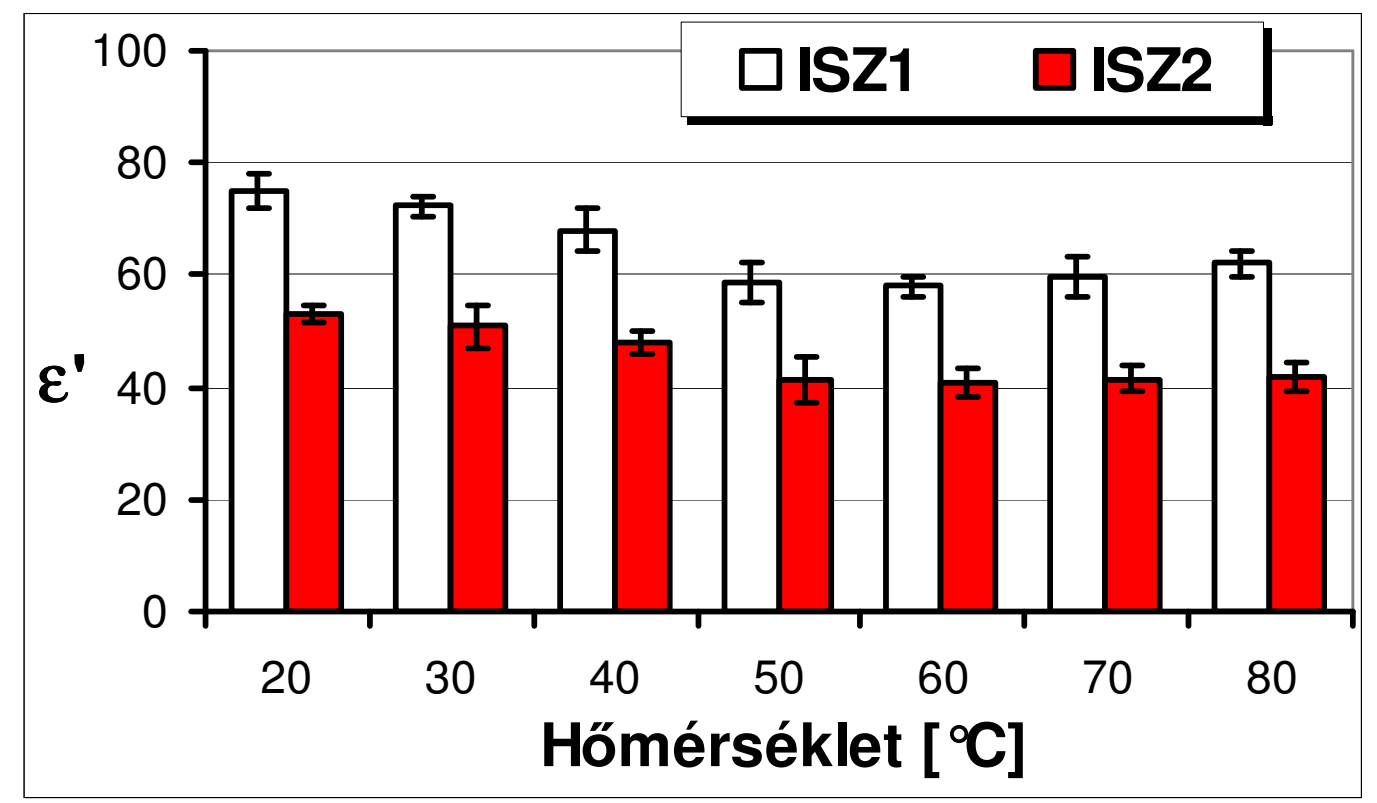

32 ábra. A dielektromos állandó hőmérsékletfüggése

A magasabb szárazanyagtartalmú iszap esetében az $\varepsilon^{\prime}$ az $50^{\circ} \mathrm{C}$ hőmérséklet eléréséig csökkent, majd az értéke nem változott az iszap további felmelegedésével. A veszteségi tényező hőmérséklet függvényében való változásának tendenciája egyezett a hígabb iszapéval. 
A dielektromos jellemzők változásának oka az iszap kétlépcsős dezintegrálódására vezethet vissza. A termikus kezelések során először az iszappelyheket stabilizáló EPS struktúra bomlik fel, majd egy kritikus hőmérséklet elérésekor az iszapban lévő sejtfalak felszakadnak, és a sejtnedv kiszabadul (Cho et al., 2012).

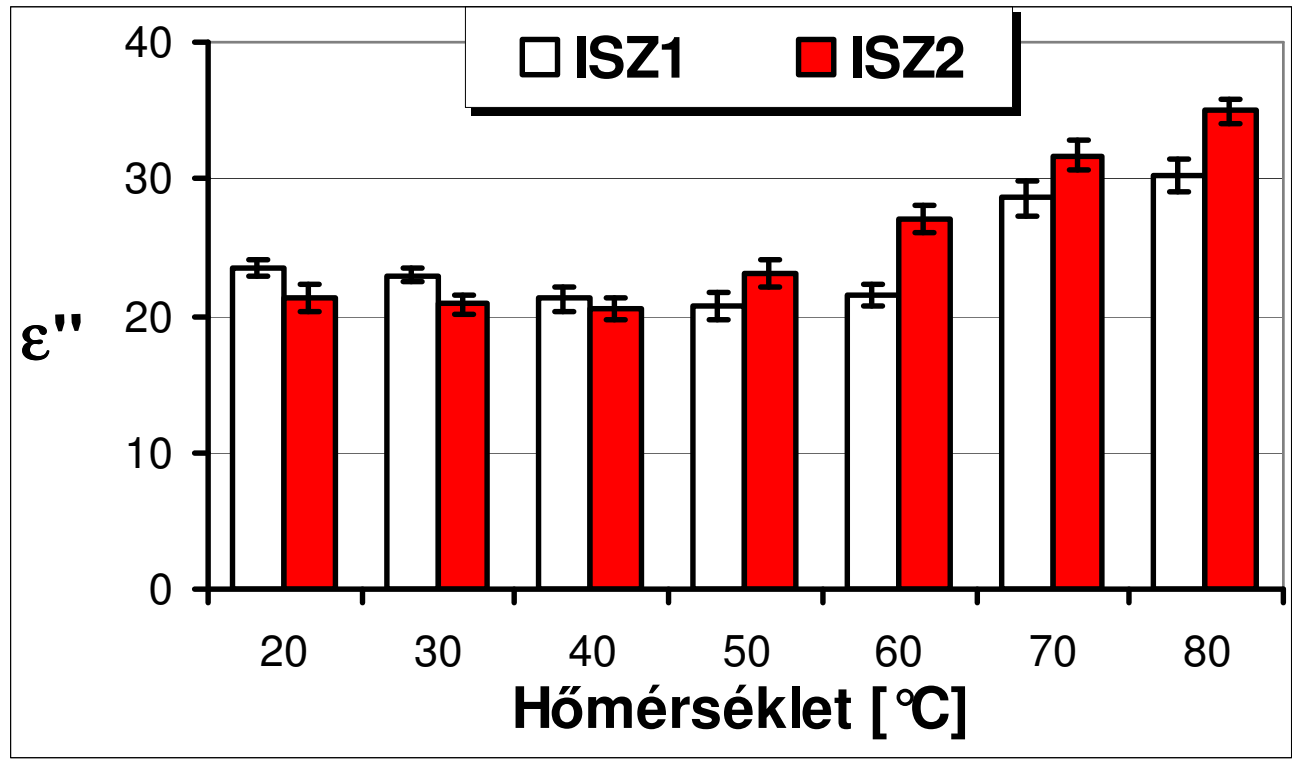

33 ábra. A dielektromos veszteségi tényező hőmérsékletfüggése

Az iszap szerkezeti változásának megfelelően az iszappelyhek dezintegrálódása, illetve a sejtfalak részleges felszakadásához szükséges hőmérséklet alatt a dielektromos jellemzők változását elsősorban az iszap eredeti szabad víztartalmának viselkedése határozza meg. Az iszapmátrixot stabilizáló polimerek felszakadásával az azokhoz kötődő víz felszabadul, a szabad víz aránya növekszik (Jones at al., 2002).

A polimerek részleges termikus hidrolízise, illetve a sejtfalak felszakadása után a sejtnedvvel kiszabaduló -mobilissá váló- ionoknak a növekvő arányú szabad víztartalomban mérhető koncentráció-emelkedése (Ahn et al, 2009) az ionos vezetés jelentőségének növekedése miatt, a dielektromos veszteségi tényező értékére egyre nagyobb hatást gyakorol, annak értékét növelve. A sejtmembránok lízise következtében az azt alkotó foszfolipidek szintén az iszapvízbe koncentrálódnak (Chu et al., 2001), amely a víztől, és a többi poláris vegyülettől eltérő szerkezet révén, a dielektromos jellemzők értékét szintén befolyásolja. 
A fentiek figyelembevételével, és mivel az iszaprészecskék destruktúrálódása, valamint a sejtfalak integritásának megszünése következtében az oldott szervesanyagok koncentrációja növekszik, a dielektromos paramétereknek a különböző hőmérsékleten történő mérésére szolgáló mintákból meghatároztam a vizes fázis kémiai oxigénigényét, illetve számítottam az oldhatósággal összefüggő SCOD/TCOD százalékos arányt is.

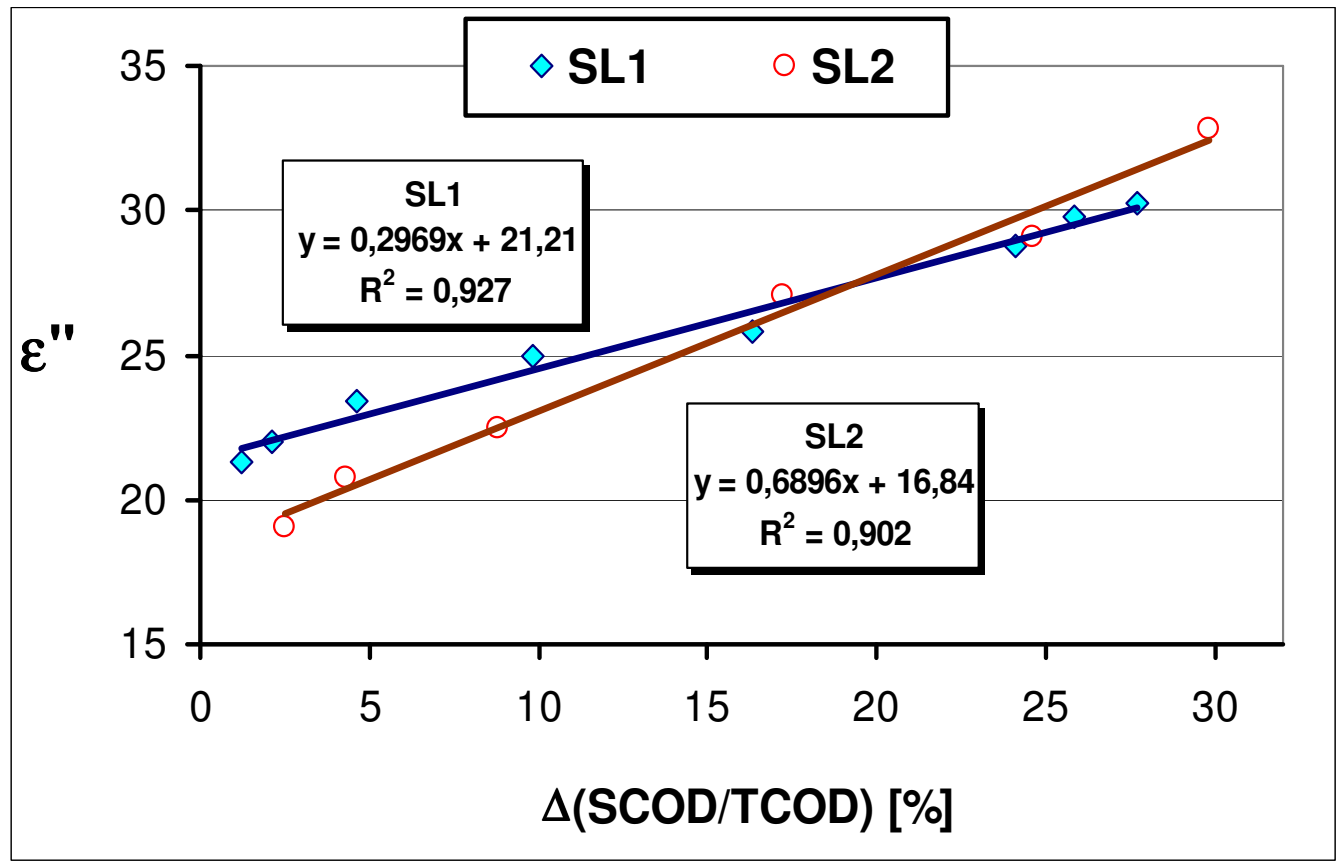

34 ábra. Az $\varepsilon "$ és az oldható szervesanyag arány változása közötti összefüggés

A dielektromos paraméterek közül a veszteségi tényező ( $\varepsilon$ ") változása, és a szervesanyag oldhatóság kontroll mintához viszonyított változása között a vizsgált iszap esetében, az alkalmazott kísérleti körülmények között, szoros lineáris kapcsolat mutatható ki (34. ábra). A termikus kezelések következtében a szervesanyagok oldhatóságában tapasztalható növekedés tehát a dielektomos veszteségi tényező mérésével nyomonkövethető, ennek értékéből az oldhatósági változások mértéke becsülhetővé válik.

A különböző szárazanyagtartalmú, és ennek következtében eltérő szervesanyag tartalmú iszapok esetében az $\varepsilon$ " és SCOD/TCOD változást tekintve látható, hogy egy adott $\varepsilon$ " értékhez, az iszap típusától, illetve kezdeti összetételi jellemzőitől függően, több oldhatósági arány is tartozhat. Ezek alapján tehát a dielektromos veszteségi tényező mérése önmagában nem alkalmas a szervesanyag oldhatóság becslésére, nem lehetséges a kezdeti analitikai paraméterek mérésének helyettesítése önmagában villamos mérési módszerrel. 
Azonban a dielektromos veszteségi tényező folyamatközbeni - vagyis egy adott anyag kezelése közben történő - meghatározásával az anyag szerkezeti változásának mértékét becsülhetjük.

Az oldhatósági változások mellett az iszapnak a BOI és KOI értékek hányadosával jellemzett biológiai bonthatóságának és a dielektromos jellemzőknek a kapcsolatát is vizsgáltam. A teljes szervesanyagon belül a biológiailag lebontható vegyületek arányának és a dielektromos veszteségi tényezőnek a kapcsolata, az oldhatóság arányhoz hasonlóan, a vizsgálat során használt iszap, illetve az alkalmazott hőmérséklettartományban lineárisnak tekinthető (35. ábra).

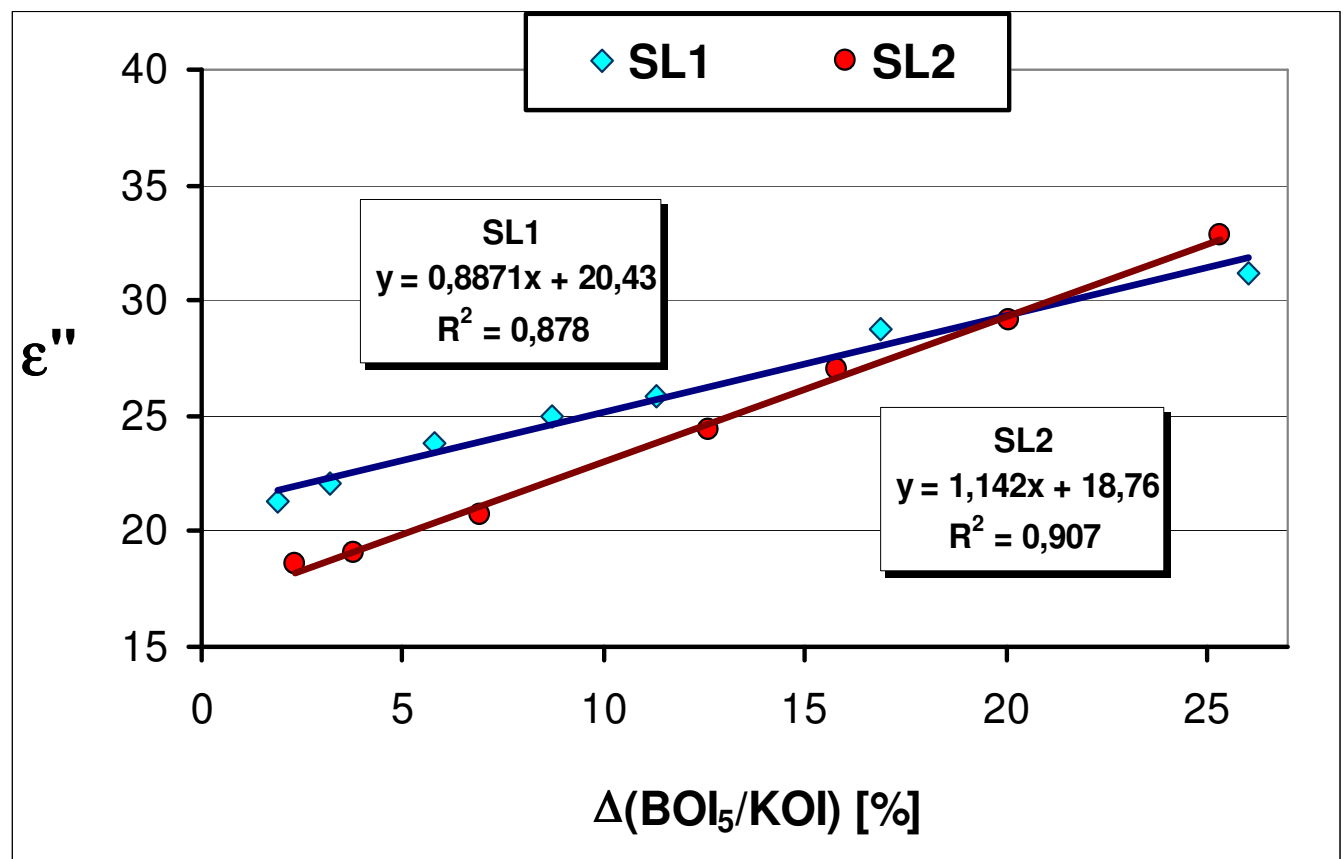

35 ábra. Az $\varepsilon$ " és a biológiailag lebontható szervesanyag arány kapcsolata

A biológiailag lebontható szervesanyagok koncentrációjának a dielektromos veszteségi tényező mérésével való nyomonkövetése esetében szintén meg kell jegyezni, hogy az $\varepsilon$ " ismerete önmagában nem elegendő a biológiai bonthatóság meghatározására, azonban a kezelések közbeni változásainak mértékéből becsülhetővé válik a bonthatóság változásának mértéke, vagyis a kezelések hatékonysága.

Az eddigi eredményeim alapján a dielektromos jellemzők mérésének jelentősége például a félüzemi, vagy üzemi méretü, folytonos anyagkezelést alkalmazó berendezések hatékonyságának ellenőrzésében, és folyamatszabályozásában lehet. 
A dielektromos jellemzők helyszíni, a kezelővonalba épített - in-line - és a valósidejü mérést és a kezelési paraméterek szabályozását lehetővé tevő - real-time - mérésével a kezelések, és a dielektromos paramétereknek a szerepe miatt elsősorban a mikrohullámú kondicionálási eljárás, biológiai lebonthatóság és energetikai szempontú, a feldolgozott anyag összetételéhez és szerkezetéhez igazodó, dinamikus optimálása válhat lehetővé.

T7: A mikrohullámú hókeltés szempontjából meghatározó dielektromos veszteségi tényezö értéke az iszapok szervesanyag oldhatóságával, és biológiai lebonthatóságával összefüggésben áll. A dielektromos veszteségi tényezőnek a kezelési folyamatok során bekövetkezö változásának mérésével a biológiai lebonthatóság mértékének növekedése becsülhetővé válik. 


\subsection{Költségbecslés és megtérülési idő számítása}

A gazdasági számítások esetében a következőket feltételeztem

- Az élelmiszeripari iszap keletkezési helyén működő üzem már rendelkezik az azt kezelő rothasztóval.

- A rothasztási technológia és müszaki berendezések alkalmasak a mikrohullámú kezelés okozta biogáz többlet kezelésére.

- A telep jelenleg is rendelkezik elegendő humáneröforrással, amely a technológiába beépítendő új egységet kezelni képes.

- A mikrohullámú előkezelő a meglévő állapotfelügyeleti, vezérlési-szabályozási rendszerbe integrálható.

- Az üzem a biogáz előállításával jelenleg is a saját energiaszükségletét fedezi, a keletkező biogáz többlet még felhasználható a vállalkozás külső energiaszükségletének csökkentésére, amely a földgáz energiahordozó helyettesítését jelenti.

- Az üzemben keletkező iszap mennyiségi és minőségi fluktuációja egynapi időintervallumban nem jelentős.

A mikrohullámú rendszer beruházási $\left(\mathrm{K}_{\mathrm{I}}\right)$ és müködtetési költségét $\left(\mathrm{K}_{\mathrm{V}}\right)$ is nagymértékben meghatározza a kezelőrendszerrel szemben támasztott teljesítményigény. A teljesítményigény számításánál a saját kísérleti eredményeimet vettem figyelembe. Ebben az esetben nem a maximális biogázkihozatal fogalmazódik meg feladatként, hanem a rendszer gazdaságos müködtetése.

Ezért az eredményeim közül a beruházási és a müködtetési költségek szempontjából is leginkább meghatározó energetikai számítások eredményeiből indultam ki. Tehát a biogáz kitermelés és ennek sebessége, a metántartalom változása és a kezelésekhez befektetett energia figyelembevételével az üzemeltetésnél

- $\quad$ az MWPL-t tekintve $2,5 \mathrm{Wg}^{-1}$

- az IMWE-t tekintve $200 \mathrm{kJg}^{-1}$ értékek javasolhatóak. 
Az előkezelés alkalmazása nélkül tejipari iszap esetében kb. $23 \mathrm{Lkg}^{-1}$ fajlagos biogázkihozatal várható kb. 48\%-os metántartalommal. A megadott paraméter tartományok alkalmazásával végzett előkezeléseket követően a várható biogázkihozatal kb. $390 \mathrm{Lkg}^{-1} \mathrm{~kb}$. 61\%-os metántartalommal.

Egy nemzetközi összehasonlításban közepes-, hazai viszonylatban nagy kapacitással rendelkező tejipari üzem napi nyersiszap produktuma a megkérdezéses felméréseim alapján kb. $750 \mathrm{~kg}$. Ebböl a feltételezett iszapproduktumból $\left(\mathrm{m}_{\mathrm{i}}\right)$, folyamatos müködést, és ezen belül napi 1 órás leállást (tisztítás, karbantartás) feltételezve az iszap tömegárama ( $\left.\mathrm{q}_{\mathrm{mi}}\right)$

$$
q_{m_{i}}=\frac{m_{i}}{\tau_{i i z}}=\frac{750 \cdot 1000[g]}{23 \cdot 3600[s]}=9,1\left[g s^{-1}\right]
$$

Ezek alapján a fajlagos teljesítmény $\left(\mathrm{P}_{\mathrm{f}}\right)$ szükséglet:

$$
P_{f}=q_{m_{i}} \cdot M W P L=9,1\left[g s^{-1}\right] \cdot 2,5\left[W^{-1}\right]=22,75\left[W^{-1}\right]
$$

A kezelőberendezés magnetronteljesítmény-igénye $\left(\mathrm{P}_{\mathrm{m}}\right)$, a fajlagos teljesítmény $\left(\mathrm{P}_{\mathrm{f}}\right)$ és az optimális MWPL és IMWE értékekből számítható tartózkodási idő $\left(\tau_{\text {tart }}\right)$ figyelembevételével

$$
P_{m}=P_{f} \cdot \tau_{\text {tart }}=22,75\left[\mathrm{Ws}^{-1}\right] \cdot 720[s]=16380[\mathrm{~W}]=16,4[\mathrm{~kW}]
$$

Ami a valós - vagyis nem a disszipálódott - magnetronteljesítményt jelenti, mivel a saját kísérleteim során meghatározott MWPL erre vonatkozott.

A költségbecsléshez, illetve a megtérülési számításoknál az ipari méretü, nagyteljesítményü, iszapkezelésre kifejlesztett és forgalmazott mikrohullámú berendezések hiánya miatt ezek beruházási költségét az építésükhöz szükséges elemek árából (magnetron, cirkulátor, tápegység, vezérlőegységek, hütőrendszer, az iszapkezelésre is alkalmassá tehető applikátorok), illetve ezek tervezési és összeszerelési költségeinek becsléséből kaptam meg.

Ezek alapján a mikrohullámú kezelő alaprendszer költsége kb. 70000 USD, vagyis az akutális MNB napi középárfolyamon (2014.07.27)

$$
K_{I}=100000 U S D \cdot 229,3 F t / U S D=22,93 M F t
$$


A mikrohullámú iszapkezelő rendszer müködtetési költségének kb. 95-97\%-át a villamosenergia felhasználás adja. A villamosenergia felhasználás tényleges költségének $\left(\mathrm{K}_{\mathrm{V}}\right)$ ipari fogyasztók esetén 90-95\%-ban a teljesítménydíjtól $\left(\mathrm{K}_{1}\right)$ és a fogyasztási díjból $\left(\mathrm{K}_{2}\right)$ tevődik össze.

A jelenleg érvényes hatósági díjszabás alapján, a magnetron átlagos villamos teljestmény transzformációs hatékonyságát tekintve $(\phi=0,51)$ a tervezett rendszer esetében ez a következő havi költségeket eredményezi:

$$
K_{1}^{\prime}=\frac{K_{1} \cdot P_{m}}{\varphi}=\frac{637\left[\frac{F t}{k W}\right] \cdot 16,4[k W]}{0,51}=20484 F t / \text { hónap }
$$

Átlagosan 30 napos hónapot, és napi 23 órás üzemidőt feltételeve a fogyasztási díj:

$$
K_{2}^{\prime}=\frac{K_{2} \cdot P_{m} \cdot 30 \cdot 23}{\varphi}=\frac{18\left[\frac{F t}{k W h}\right] \cdot 16,4[k W] \cdot 690[h]}{0,51}=390400 \mathrm{Ft} / \text { hónap }
$$

Ezekből a [41] és [42] összefüggésekből kapott eredmények összegzésével a havi teljes üzemeltetési költség:

$$
K_{V}=K_{1}^{\prime}+K_{2}^{\prime}=410900 \mathrm{Ft} / \text { hónap }
$$

A feldolgozott iszap havi mennyiségét figyelembevéve a mikrohullámú iszapkondicionálás fajlagos (iszaptömegre vonatkoztatott) költsége (k) a [44] összefüggés eredményeképpen kapható meg:

$$
k=\frac{K_{V}}{30 \cdot m_{\text {iszap }}}=\frac{410900[\mathrm{Ft} / \text { hónap }]}{30 \cdot 750[\mathrm{~kg} / \mathrm{nap}]}=18,26[\mathrm{Ft} / \mathrm{kg}]
$$

A mikrohullámú rendszer esetében a bevétel (R) a felhasználói oldalon a földgáz helyettesítésére, vagy más felhasználók számára értékesített, a kezelések hatására képződő többlet biogáz metántartalma jelenti. 
A feldolgozott iszapmennyiséget $\left(\mathrm{m}_{\mathrm{i}}\right)$, illetve ennek fajlagos biogázkitermelési mutatóját ( $Y_{\text {biogáz }}$ ), valamint a biogáz (kezelések hatására magasabb) metánkoncentrációját $\left(\mathrm{c}_{\mathrm{v}(\mathrm{CH} 4)}\right)$ tekintve a havi metántöbblet a következőképpen, a [45] összefüggéssel számítható:

$$
V_{\mathrm{CH}_{4}}=30 \cdot \mathrm{m}_{\mathrm{i}} \cdot \Delta Y_{\text {biogáz }} \cdot c_{V_{\mathrm{CH}_{4}}}=30 \cdot 750[\mathrm{~kg}] \cdot 367[\mathrm{~L} / \mathrm{kg}] \cdot 0,61=5037,1\left[\mathrm{~m}^{3} / \mathrm{hónap}\right]
$$

Nem-lakossági felhasználókat tekintve a földgáz bruttó díja (FÁ) 4,54 Ft/MJ. A metán átlagos energiatartalmával (q 40 $\mathrm{MJ} / \mathrm{m}^{3}$ ) számítva a keletkező biogázzal, a földgáz helyettesítése révén kapott nyereség számítható.

$$
\begin{aligned}
& R=V_{\mathrm{CH}_{4}} \cdot F A ́ \cdot q=5037,1\left[\mathrm{~m}^{3} / \text { hónap }\right] \cdot 4,54[\mathrm{Ft} / \mathrm{MJ}] \cdot 40\left[\mathrm{MJ} / \mathrm{m}^{3}\right]= \\
& =914738 \mathrm{Ft} / \text { hónap }
\end{aligned}
$$

A rendszer müködtetési költségét figyelenbe vevő korrigált 'nettó' nyereség (R') a nyereség $(\mathrm{R})$ és a teljes müködési különbségeként $\left(\mathrm{K}_{\mathrm{V}}\right)$ képezhető:

$$
R^{\prime}=R-K_{V}=914738-410900=503838 \text { Ft } / \text { hónap }
$$

A mikrohullámú rendszer bekerülési költségének $\left(\mathrm{K}_{\mathrm{I}}\right)$ és a havi korrigált nyereség (R') ismeretében a megtérülési idő ( $\left.\tau_{\text {megt }}\right)$ a következőképpen adható meg:

$$
\tau_{\text {megt }}=\frac{K_{I}}{R^{\prime}}=\frac{22930000 \mathrm{Ft}}{503838 \mathrm{Ft} / \text { hónap }}=45,5 \text { hónap }
$$

Ha ugyanezen rendszert azonos napi volumenü húsipari iszap előkezelésére használjuk, a rendszer bekerülési és üzemeltetési költségét, valamint a fajlagos iszapkezelési költséget azonosnak tekinthetjük a tejipari iszap esetében leírtakéval.

A nyereség számításánál azonban a kezelés hatására bekövetkező biogázproduktum növekedés eltérö, így azt [45] összefüggés módosításával a húsipari iszap adataival számíhatjuk

$$
V_{C H_{4}}(\text { húsip })=30 \cdot m_{i} \cdot \Delta Y_{\text {biogáz }} \cdot c_{V_{C_{4}}}=30 \cdot 750[\mathrm{~kg}] \cdot 195[\mathrm{~L} / \mathrm{kg}] \cdot 0,62=2720,3\left[\mathrm{~m}^{3} / \text { hónap }\right]
$$


Ebből a nyereség a [46] összefüggéssel analóg módon számítva:

$$
\begin{aligned}
& R=V_{\mathrm{CH}_{4}} \cdot \mathrm{FÁ} \cdot q=2720,3\left[\mathrm{~m}^{3} / \text { hónap }\right] \cdot 4,54[\mathrm{Ft} / \mathrm{MJ}] \cdot 40\left[\mathrm{MJ} / \mathrm{m}^{3}\right]= \\
& =494006 \mathrm{Ft} / \text { hónap }
\end{aligned}
$$

Mindezek figyelembevételével a megtérülési idő húsipari iszap mikrohullámú kezelése esetében

$$
\tau_{\text {megt }}=\frac{K_{I}}{R-K_{V}}=\frac{22930000 \mathrm{Ft}}{494006-410900 \mathrm{Ft} / \text { hónap }}=275,9 \text { hónap }
$$

A megtérülési idő számításának eredményei alapján tehát igazolható, hogy a mikrohullámú kondicionálási módszer alkalmazása azon típusú alapanyagok esetében gazdaságos, amelyek eredeti biológiai lebonthatósága erősen korlátozott. Ebben az esetben a mikrohullámú rendszer (4 évnél rövidebb idejü) megtérülése kedvezőnek ítélhető.

A jelen költségbecslés és megtérülési számítások esetén feltételezett feldolgozási kapacitást jelentősen meghaladó iszapproduktum esetében azonban már figyelembe kell venni a teljesítményigénnyel exponenciálisan növekvő beruházási költségeket, amelyek a gazdaságossági mutatókat nagyban ronthatják. 


\section{6 ÖSSZEFOGLALÁS}

Napjainkban az elérhető és biztonságos ivóvízkészletek csökkenésével a szennyvíztisztítási eljárások kapacitásigényével és a tisztítási hatásfokukkal szemben támasztott követelmények fokozódnak. A szennyvízkezelés technológiai és müszaki fejlődésével párhuzamosan azonban az azokban képződő iszapok mennyisége is növekszik. Az iszapkezelési eljárások tervezése során, a környezetvédelmi és a jogszabályi változások miatt, egyre inkább a hasznosításra koncentrálnak. Az iszapok hasznosítása legtöbb esetben valamilyen előkezelési eljárást igényel.

Az utóbbi évek kutatási eredményei alapján a mikrohullámú energiaközlés alkalmasnak bizonyult a különböző hulladékok és melléktermékek hatékony kezelésére. A hagyományos termikus módszerekkel összehasonlítva legfontosabb előnyei közé tartozik az igen gyors hőfejlesztő képessége, az eltérő hőkeltési mechanizmusa révén a térfogati felmelegítő hatása, az összetett rendszerekben tapasztalható szelektív felmelegítő hatása és az igen rövid műveleti idő szükségelete. Mindezen előnyös tulajdonságai mellett azonban megállapítható, hogy a mikrohullámú anyagkezelési eljárások több alapanyag esetében nem kellő mélységben vizsgáltak.

A szakirodalom a mikrohullámú iszapkezelés esetében szinte kizárólagosan a kommunális eredetű iszapokkal kapcsolatos eredményekről számol be. Az egyes közleményekben leírt eredmények objektív összehasonlítása az eltérő kísérleti körülmények és sok esetben a nem kellően definiált kontrollparaméterek miatt nehézkes, az így nyert tapasztalatok más anyagtípusra való adaptálása téves következtetésekhez vezethet.

Mindezen okok miatt a doktori munkám során az élelmiszeripari eredetü iszapok mikrohullámú kezelésének a biológiai lebonthatóság szempontjából értelmezett hatékonyságát és a mikrohullámú műveleti paraméterek hatásait vizsgáltam.

A tejipari és húsipari iszapok esetében az atmoszferikus nyomáson kivitelezett mikrohullámú kezelésnek az iszapszerkezet stabilitását biztosító extracelluláris polimer vegyületekre (EPS) és a sejtfalakra gyakorolt roncsolóhatása következtében, a szervesanyagok oldhatóságát jellemző, kémiai oxigénigény méréssel meghatározható, SCOD/TCOD aránya a hagyományos termikus módszereknél matematikai statisztikai módszerekkel igazolhatóan szignifikánsan nagyobb mértékben növekedett. A növekmény 
mértéke a kezelési körülményektől függően a tejipari iszapnál a 250\%-ot is elérheti, illetve húsipari iszapnál a 30\%-ot meghaladhatja.

A biokémiai oxigénigény (BOI) méréssel meghatározható, az aerob körülmények között lebontható szervesanyagok mennyisége a mikrohullámú energiaközlés hatására, a további biológiai eljárásokban való iszaphasznosítás szempontjából előnyösen változott. Az iszap típusától, és a kezelési körülményektől függően a szervesanyagoknak az aerob lebontó mikroorganizmusok számára lebontható aránya a kezeletlen iszaphoz képest a mikrohullámú energiaközléssel 50-220\%-al növelhető.

Az eredményeim alapján látható, hogy a mikrohullámú eljárás hatása a kisebb kezdeti lebonthatósággal jellemezhető tejipari iszapok esetében kifejezettebb. A mikrohullámú eljárás hatékonyságának igazolása mellett azonban megállapítottam, hogy a szervesanyagok oldható formában lévő frakcióinak arányát, valamint az aerob körülmények között lebontható komponensek arányát tekintve a fajlagos kezelési teljesítmény-intenzitás egyaránt befolyásolja a kezelések hatékonyságát.

Az eltérő eredetű, illetve a sokszor jelentősen változó összetételü iszapokkal végzett mikrohullámú kezelések hatékonyságának összehasonlíthatósága érdekében a kezdeti összetételi paraméterektől független, a kezelések hatását mérő mutatókat fejlesztettem. A szervesanyag frakciók oldhatósági változásainak mérésére az oldhatósági index (SLI), illetve a szervesanyagon belül az aerob úton bontható vegyületek arányának változásának jellemzésére a biodegradálhatósági index (BDI) paramétereket definiáltam.

Az SLI és BDI mutatókat, mint kontrollparamétereket felhasználva kísérlettervezés és válaszfelület elemzési módszerrel (RSM) alkotott fiziko-matematikai modellalkotást követően vizsgáltam a teljesítménytől és a besugárzási időtől függő mikrohullámmal közölt energia (IMWE) és a fajlagos kezelési teljesítmény-intenzitás (MWPL) müveleti paraméterek hatásait.

Az eredményeim alapján megállapítottam, hogy a vizsgált paramétertartományban (IMWE: 90-1050 kJ; MWPL 0,5-5 $\mathrm{Wg}^{-1}$ ) az aerob lebonthatóságot jelző BDI értékének növekedése maximum tartománnyal jellemezhető, az IMWE és MWPL egy határon túli növekedése már negatívan befolyásolja a lebonthatóság mértékét. Az aerob lebonthatóság szempontjából legkedvezőbbnek tekinthető paramétertartomány az MWPL esetében 1,75 $\mathrm{Wg}^{-1}-3,5 \mathrm{Wg}^{-1}$, az IMWE esetében $550 \mathrm{kJg}^{-1}-700 \mathrm{kJg}^{-1}$. 
A müveleti paraméterek hatását elemezve megállapítottam, hogy mind az IMWE, mind az MWPL szignifikáns hatást gyakorol mindkét vizsgált változóra, vagyis az oldhatósági indexre és a biodegradálhatósági indexre egyaránt. A dielektromos jellemzők mérésével igazoltam, hogy a dielektromos veszteségi tényező ( $\varepsilon ")$ és a szervesanyagok oldhatósági változása, valamint a biológiai lebonthatóság mértékének változása között korreláció mutatható ki. A villamos paraméterek és a biológiai lebnthatóság összefüggése a folyamatos mikrohullámú anyagkezelő rendszerek szabályozására, illetve a kezelések hatékonyságának folyamatközbeni ellenörzésére is alkalmas.

A mikrohullámú előkezelésnek az anaerob lebonthatóságra gyakorolt hatásait mezofil hőmérséklettartományú rothasztási tesztekkel vizsgáltam. Az anaerob fermentációs kísérletek eredményei alapján megállapítottam, hogy a mikrohullámú energiaközlés előnyösen hat az anaerob lebonthatóság mértékére. A mikrohullámú eljárás az élelmiszeripari iszapok esetében a fajlagos biogázkiteremlési mutatót, a rothaszthatóság mértékét és a lebontási ütemmel összefüggő biogázképződési sebességet, a hagyományos termikus módszereknél hatékonyabban növeli.

Az anaerob fermentáció szempontjából leghatékonyabbnak tekinthető mikrohullámú előkezelés alkalmazásával a tejipari iszap esetében, a kezeletlen iszaphoz képest, közel 19szeres húsipari iszapnál kb. 1,2-szeres biogáztérfogatot eredményezett. A mikrohullámú kezelés műveleti paramétereit tekintve megállapítottam, hogy a BDI esetében meghatározott optimális IMWE és MWPL tartománynál intenzívebb energiaközlés az anaerob fermentáció szempontjából a keletkező biogáz térfogatát még növelte.

A vizsgálataim alapján a mikrohullámú előkezelés a 30 napos rothasztás alatt keletkező biogázban a metán komponens arányát növelte. A kezelések során az anyaggal közölt energia, valamint a hatására keletkező többlet biogáz energiatartalmának különbségeként meghatározott nettó energia-hasznosulási mutatói alapján azonban megállapítottam, hogy az energetikai szempontok alapján meghatározott optimális IMWE és MWPL tartományok nincs teljes átfedésben a lebonthatóság szempontjából meghatározottakkal. A mikrohullámú előkezelés a korlátozott eredeti bonthatóságú, ezáltal alacsony kezdeti biogázkitermelési mutatóval jellemezhető iszapok esetében az eljárás költség-haszon elemzése alapján hatékonynak tekinthető, a beruházás - 4 évnél kisebb - megtérülési mutatója kedvező. 


\section{7 ÚJ TUDOMÁNYOS EREDMÉNYEK}

$\mathrm{Az}$ értekezés tematikus alfejezeteinek végén szereplő új tudományos eredményeket összefoglalásként, az egyes rész-tézispontokat összevonva a következőekben sorolom fel:

T1) Élelmiszeripari iszapok esetében az atmoszferikus nyomáson végzett mikrohullámú kezelés, az atmoszferikus nyomáson kivitelezett, hagyományos termikus kezelésekhez képest, rövidebb múveleti időszükséglet mellett, nagyobb mértékben növeli a szervesanyagok oldhatóságát és az aerob folyamatokban lebontható vegyületek koncentrációját, amely alkalmassá teszi a módszert a biológiai iszapkezelési eljárások szervesanyag hasznosításának intenzifikálására.

A kémiai oxigénigény mérési módszerrel meghatározható, az összes szervesanyag tartalmon belüli vízoldható összetevők arányát jelzö, SCOD/TCOD paraméter a tejipari iszap esetében a kezdeti 9,7\%-ról 30\% fölé, húsipari iszap esetében 29\%-ról 45\%-ra növelhetö mikrohullámú kezeléssel. Az aerob körülmények között lebontható szervesanyagok koncentrációjával arányos BOI értéke a kezeletlen mintához képest, mikrohullámú kezelésekkel a tejiapri iszap esetében négyszeresére, húsipari iszap esetében közel háromszorosára növelhetö.

T2) A mikrohullámú iszapkezelési eljárásnak, a szervesanyagfrakció oldhatósága, valamint a biológiailag lebontható szervesanyagok koncentráció változása szempontjából értelmezett hatékonyságát, a mikrohullámú sugárzás behatási idején túl, a kezelt anyag egységnyi tömegére vonatkoztatott, azaz fajlagos teljesítmény-intenzitás is befolyásolja.

Mind a tejipari, mind a húsipari eredetü iszap esetében a szervesanyag vízoldhatóság mértékével arányos SCOD/TCOD arány növekedését, továbbá a szervesanyag tartalmon belül a biológiailag lebontható vegyületek arányát jelzö BOI/KOI arány változását a fajlagos mikrohullámú kezelési teljesítményintenzitás a vizsgált $0,5-5 \mathrm{Wg}^{-1}$ tartományban szignifikánsan befolyásolja. 
T3) Az aerob biológiai lebonthatóság jellemzésére fejlesztett biodegradálhatósági index (BDI), és a szervesanyagok vizes fázisban mérhető koncentráció változás jellemzésére fejlesztett oldhatósági index (SLI) alkalmas a mikrohullámú iszapkezelés múveleti paraméterei hatásának objektív vizsgálatára, és azok optimálására.

Az oldhatósági index (SLI) valamint a biodegradálhatósági index (BDI) az alábbi, a fajlagos teljesítmény-intenzitást (MWPL) tekintve a 0,5-5 $\mathrm{Wg}^{-1}$, illetve az anyaggal közölt mikrohullámú energiát (IMWE) tekintve 90-1050 $\mathrm{kJg}^{-1}$ tartományban érvényes modellekkel becsülhetö:

$$
\begin{aligned}
& \text { SLI }=0,8085+0,301 x_{1}+0,014 x_{2}+0,0706 x_{1} x_{2}-0,237 x_{1}^{2}+0,036 x_{2}^{2} \\
& \text { BDI }=0,8921+0,071 x_{1}-0,002 x_{2}-0,298 x_{1}^{2}+0,043 x_{2}^{2}
\end{aligned}
$$

Ahol $x_{1}$ jelöli az IMWE, $x_{2}$ pedig az MWPL paramétert.

T4) A mikrohullámú energiaközlésen alapuló előkezelés az anaerob fermenteció során a biogázkitermelési mutatót az alkalmazott fajlagos kezelési teljesítmény-intenzitástól függő mértékben javítja, továbbá a képződő biogáz metán tartalmát növeli élelmiszeripari iszapok esetében.

A mikrohullámú elökezelés alkalmazásával az anaerob körülmények között nehezen bontható tejipari iszap biogáz-kitermelési mutatója a kezeletlen iszaphoz képest közel 19-szeresére, míg a húsipari iszap esetében 1,2-szeresére növelhetö. A leghatékonyabbnak tekinthetö mikrohullámú kezeléssel a biogáz metántartalma 25\%-ot meghaladó mértékben növelhetö volt mind a tejipari, mind a húsipari iszap esetében.

T5) A mikrohullámú iszapkondicionálási eljárás az élelmiszeripari iszapok anaerob fermentációs folyamatban való hasznosítása során alkalmas a rothasztási időszükséglet hatékony csökkentésére, továbbá az anaerob lebomlás ütemének felgyorsítása révén a biogáz képződési sebességének növelésére. 
A mikrohullámú kezelésekkel a biogázképzödés kezdetéhez szükséges idö mezofil rothasztás esetében tejipari iszapnál 80\%-al, húsipari iszapnál 75\%-al rövidül le. A 30 napos fermentációs idöszak alatt a biogáz képzödés ötnapos lineáris felfutási szakaszából meghatározott átlagos gáztermelödési sebesség a kezeletlen iszaphoz képest, tejipari iszapnál húszszorosára, húsipari iszapnál háromszorosára növelhetö mikrohullámú kezelések alkalmazásával.

T6) A mikrohullámú iszap kondicionálási eljárás esetében a biogázproduktum, és annak metántartalma alapján meghatározott optimális múveleti paramétertartományok nem azonosak az energetikai szempontú optimálás során meghatározottal. A rothasztást megelőző mikrohullámú előkezelés hatékonyságának elemzésekor az energia-hasznosulási mutató alkalmazása szükséges.

Az anaerob fermentációt megelöző mikrohullámú kezelés energiahatékonysága $(\Delta E)$ a kezelés teljesítmény-igényének és idejének, valamint a hatására képzödö biogáz többlet fütöértékének figyelembevételével jellemezhetö. A kezelések energetikai szempontú optimálása az IMWE $\left(x_{1}\right)$ és MWPL $\left(x_{2}\right)$ müveleti paramétereket tartalmazó modell alkalmazásával végezhetö.

$$
\Delta E=326.12-27.29 X_{1}-237.74 X_{2}-4.017 X_{1}^{2}-470.79 X_{2}^{2}-385.9 X_{1} X_{2} \quad\left[J g^{-1}\right\rfloor
$$

T7) A mikrohullámú hőkeltés szempontjából meghatározó dielektromos veszteségi tényező értéke az iszapok szervesanyag oldhatóságával, és biológiai lebonthatóságával összefüggésben áll. A dielektromos veszteségi tényezőnek a kezelési folyamatok során bekövetkező változásának mérésével a biológiai lebonthatóság mértékének növekedése becsülhetővé válik.

Az iszapot alkotó szervesanyagok vízoldhatóságának változásával arányos SCOD/TCOD paraméter, valamint a biológiailag lebontható szervesanyag frakciók koncentráció változásával arányos BOI/KOI paraméter a dielektromos veszteségi tényező ( $\left.\varepsilon^{\prime \prime}\right)$ értékének változásával szoros $\left(R^{2}>0,9 ;\right.$ ill. $\left.R^{2}>0,85\right)$ kapcsolatban áll. 


\section{SUMMARY}

Nowadays, because of the shortening of water resources, expectations for higher capacity and cleaning efficiency of wastewater purification technologies are growing. Notwithstanding of the technological development of wastewater treatment works the amount of sludge produced in these process is continuously increasing. Taking into consideration the environmental awareness and the more and more rigorous pollution control regulations, the research and development activity focuses on the sludge utilization processes. However the sludge utilization and valorization technologies require applying pre-treatments.

Previous investigations have been verified, that microwave irradiation is applicable in various waste and by-products handling technologies with high efficiency. The main advantages of microwave technique over the conventional thermal heating methods are the follow: rapid heat generation, volumetric heating, selecting heating in multicomponent system and the very short processing cycle time. Beside these advantages, it can be concluded, that the effects and efficiency of microwave processes are not enough deeply investigated and analyzed for many types of materials. It can be also established, that results of studies on microwave sludge conditioning obtained mainly from municipal sludge processing.

Comparing of the results obtained from different studies has difficulties because of the different condition of experimental set-up, and the undefined or not exactly defined control parameters used for evaluation of microwave process. Therefore these observations are often led to incorrect conclusion, determined optimum parameters can not be used for another material or equipment, and make complicated the scale up of processes. Taking into consideration the above mentioned, the objective of my work was the investigation of the efficiency of microwave treatment process on the biodegradability of food industry sludge, and analyzis of the effect of microwave process parameters.

Because of the strong disintegration effect of microwave irradiation on extracellular polymeric substances (EPS), which form complex sludge structure, and also on microbial cell walls has led to enhanced solubility of organic matters of food industry sludge, given by the ratio of soluble to total chemical oxygen demand (SCOD/TCOD). Increasing of organic matter solubility of microwave irradiated dairy and meat processing sludge was 
statistically and significantly higher than that of obtained from conventionally heated samples. By microwave treatment, an increment of $250 \%$ and over $30 \%$ in the SCOD/TCOD value was achieved for dairy and meat processing sludge, respectively.

From the aspect of the further utilization of sludge, the change of biochemical oxygen demand (BOD), which correlates the degradable organic matters of sludge under aerobic condition, can be considered advantageous. Depend on the type of sludge, and the process parameters of microwave treatment, amount of the available substrate, i.e. the biodegradable compounds, increased by $55-220 \%$ compared to the untreated control sample.

My results proved that the microwave pre-treatment has a stronger effect on the biodegradability of dairy sludge with more resistant original sludge structure, than on the meat processing sludge. Beside the verified overall efficiency of microwave process, it was also established, that the specific microwave power intensity has significant influence on the change of organic matter solubility and the aerobically degraded component of sludge, as well.

For comparison purpose, and for modeling and optimization of process, it is needed to create novel control parameters, by which can be measured the changes in organic matter fraction of sludge independently from the varying characteristic or different origin of raw sludge. To quantify the change in the solubility of organic matter of sludge and in the degree of biodegradability the solubilization index (SLI) and the biodegradation index (BDI) were developed. Defined SLI and BDI as control parameters, effects and significance of irradiated microwave energy (IMWE) and microwave power level (MWPL) were investigated with experimental design and response surface methodology (RSM).

Based on my results, I have established that in the range of $90-1050 \mathrm{kJkg}^{-1}$, and $0,5-5$ $\mathrm{Wg}^{-1}$ for IMWE and MWPL, the surface fitted by constructed model can be characterized by a maximum value for BDI. Microwave treatment carried out over a certain value of MWPL and IMWE has resulted in lower biodegradability. Optimum range of IMWE and MWPL was concluded as $600-650 \mathrm{~kJ}$ and $2,5-3,0 \mathrm{Wg}^{-1}$, respectively, and both process parameters have significant effect on the change of BDI and SLI, as well. 
Furthermore, in another series of my experiments I have verified correlation between the organic matter solubility, degree of biodegradability and the dielectric loss factor $(\varepsilon ")$. Relationship between the dielectric parameters and biodegradability provide facility to an in-line and real-time estimation and control the efficiency of microwave sludge conditioning process.

Mesophilic anaerobic digestion (AD) tests were applied to examine the effect of microwave pre-treatment on the anaerobic degradation. It was proved, that microwave irradiation as pre-treatment before $\mathrm{AD}$ process was more effective than conventional heating, which is resulted in higher biogas yield, organic matter removal efficiency, and accelerated biogas production rate.

By microwave pre-treatment, the volume of produced biogas from dairy and meat industry sludge was 19-times and 1.2 times higher, than that of obtained from raw sludge. From the aspects of biogas yield and the rate of anaerobic degradation the optimum range of IMWE and MWPL was higher than determined for BDI. Over the optimum MWPL or IMWE level the aerobic degradability start to decrease, but the enhanced power intensity of microwave pretreatment could increase further the efficiency and the rate of biogas production.

My experimental results demonstrated that microwave irradiation could increase the methane production during a 30 days fermentation process. Net energy product of microwave pre-treatment was calculated as the difference between the energy content of produced surplus biogas and the irradiated microwave energy. Based on my calculations can be concluded, that despite of higher biogas yield, MW pre-treatment at higher MWPL and using increased IMWE were not favorable from energetic aspects, the optimum range for net energy product was not the same that was determined for maximum biogas production. Cost-benefit analysis shows that investment to a medium capacity microwave sludge conditioning equipment has a short (less than 4 years) payback period for food industry sludge with low original biodegradability. 


\section{IRODALOMJEGYZÉK}

1) Adhikari B., De D., Maiti S. Reclamation and recycling of waste rubber. Progress in Polymer Science 25, 2000, 909-948.

2) Ahn J.H., Shin S.G., Hwang S. Effect of microwave irradiation ont he disintegration and acidogenesis of municipal secondary sludge. Chemical Engineering Journal 153, 2009, 145150.

3) Aklhori S., Minaev B., Stone-Elander, S., Elander N. Quantum Chemical Model of an $\mathrm{S}_{\mathrm{N}} 2$ Reaction in a Microwave Field. Journal of Physical Chemistry. A, 106(37), 2002, 8516-8524

4) Almássy Gy. Mikrohullámú mérőműszerek és mérések. Műszaki Könyvkiadó, Budapest, 1964, $380 \mathrm{p}$.

5) Appels L., Degreve J., Van der Bruggen B., Van Impe J., Dewil R. Influence of low temperature thermal pre-reatment on sludge solubilization, heavy metal release, and anaerobic digestion. Bioresource Technology 101, 2010, 5743-5748.

6) Appels L., Houtmeyers S., Dereve J., Van Impe J., Dewil R. Influence of microwave pretreatment on sludge solubilization and pilot scale semi-continuous anaerobic digestion. Bioresource Technology 128, 2013, 598-603.

7) Ayappa, K.G., Davis, H.T., Grapiste, G., Davis, E.A., Gordon, J. Microwave heating: an evaluation of power formulations, Chemical Engineering Science 46, 1991, 1005-1016.

8) Baghurst DR., Whittaker AG. Microwave dielectric heating effects in chemical synthesys. In: Chemistry under non-classical condition. Ed.: van Eldik R. and Hubbard CD., John Wiley \& Sons, New York, 1997, 479-514.

9) Banik S., Bandyopadhyay S., Ganguly S. Bioeffects of microwave-a breif review, Bioresource Technology 87, 2003, 155-159

10) Barótfi I. Környezettechnika. Mezőgazda Kiadó, Budapest, 2000, 981p.

11) Beke, J. Terményszárítás. Agroinform Kiadó, Budapest, 1997, 419p.

12) Beneduci A. Which is the effective time-scale of the fast Debye relaxation proces in water. Journal of molecular liquids 138(1-3), 2008, 55-60.

13) Bengtsson N.E., Risman P.O. Dielectric properties of foods at $3 \mathrm{GHz}$ as determined by a cavity perturbation technique. Journal of Microwave Power EM Energy 6, 1971, 107-123.

14) Bhattacharya M., Basak T. A novel closed-form analysis on asymptotes and resonances of microwave power. Chemical Engineering Science, 61 (19), 2006, 6273-6301.

15) Binod P., Satyanagalakshmi K., Sindhu R., Janu K.U., Sukumara R., Pandey A. Short duration microwave assisted pretreatment enhances the enzymatic saccharification and fermentable sugar yield from sugarcane bagasse. Renewable Energy 37, 2012, 109-116.

16) Bo L.L., Zhang Y.B., Quan X., Zhao B. Microwave assisted catalytic oxidation of p-nitrophenol in aqueous solution using carbon-supported copper catalyst. Journal of Hazardous Material $153,2008,1201-1206$.

17) Bogdal D., Loupy A. Application of microwve radiation to phase-transfer catalyzed reactions. Organic Process Research and Development, 12(4), 2008, 710-722.

18) Bohdziewicz J., Sroka E. Application of hybrid systems to the treatment of meat industry wastewater. Desalination, 198, 2006, 33-40.

19) Bohr H., Bohr J. Microwave enhanced folding and denaturation of globular proteins. Physical Review 61, 2000a, 4310-4314.

20) Bohr H., Bohr J. Microwave enhanced kinetics observed in ORD studies of a protein. Bioelectromagnetics 21, 2000b, 68-72. 
21) Bougrier C., Delgenes J.P., Carrere H. Impacts of thermal pretreatments ont he semi-continuous anaerobic digestion of waste activated sludge. Biochemical Engineering Journal, 34(1), 2007, 20-27.

22) Brooks R.B. Heat treatment of sewage sludge. Water Pollution and Control, 69(2), 1970, 221231.

23) Chandrasekaran S., Ramanathan S., Basak T. Microwave material processing-a review. Fluid Mechanics and Tranport Phenomena, 58(2), 2012, 330-363.

24) Chen Y., Cheng J.J., Creamer K.S. Inhibition of anaerobic digestion process: a review. Bioresource Technology, 99, 2008, 4044-4054.

25) Chi Y., Li Y., Fei X., Wang S., Yuan H. Enhancement of thermophilic anaerobic digestion of thickened waste activated sludge by combined microwave and alkaline pretreatment. Journal of Environmental Sciences 23(8), 2011, 1257-1265.

26) Cho SK., Shin HS., Kim DH. Waste activated sludge hydrolysis during ultrasonication: twostep disintegration. Bioresource Technology 44, 2012, 480-483.

27) Chu C.P., Chang B.V., Liao G.S., Jean D.S., Lee D.J. Observationas on changes in ultrasonically treated waste-activated sludge. Water Research 35, 2001, 1038-1046.

28) Churchland M.T. Microwaves:Theory and Application in materials Processing III. American Ceramic Society, Westerwille, OH, 1995, 63 p.

29) Clark D.E., Folz D., West J.K. Processing materials with microwave energy. Materials Science and Engineering A287, 2000, 153-158.

30) Climent M., Ferrer I., Baeza M., Artola A., Vazquez F., Font F. Effects of thermal and mechanical pretreatments of secondary sludge on biogas production under thermophilic conditions. Chemical Engineering Journal 133, 2007, 335-342.

31) Constable D., Raner K., Somlo P., Strauss C. A New Microwave Reactor Suitable for Organic Synthesis and Kinetics Studies. Journal of Microwave Power and Electromegnetic Energy, 27(4), 1992, 195-198.

32) Coss PM., Cha CY. Microwave regeneration of activated carbon used for the removal of solvents from vented air. Journal of the Air and Waste Management Association, 50(4), 2000, 529-535.

33) Curet, S., Rouaud, O., Boillereaux, L. Microwave tempering and heating in a single-mode cavity: Numerical and experimental investigations. Chemical Engineering and Processing, 47, 2008, 1656-1665.

34) de la Hoz A., Diaz-Ortiz A., Moreno A. Microwaves in organic synthesis. Thermal and nonthermal microwave effects.Chemical Society Reviews 34(2), 2005, 164-178.

35) de los Santos J., Garsia D., Eiras J.A. Dielectris chracterization of materials at microwave frequency range. Materials Research 6(2003), 742-746.

36) De Sena R., Claudino A., Moretti K., Bonfanti I.C.P., Jose H.J. Biofuel application of biomass obtained from a meat industry wastewater plant through the flotation process-a case study. Resozrces, Conservation and Recycling 52, 2008, 557-569.

37) Dogan I., Sanin F.D. Alkaline solubilization and microwave irradiation as a combined sludge disintegration and minimization method. Water Research 43, 2009, 2139-2148.

38) Dwyer J., Starrenburg D., Tait S., Barr K., Batstone T.J., Lant P. Decreasing activated sludge thermal hydrolysis temperature reduces product colour, without decreasing degradability. Water Research 42(18), 2008, 4699-4709.

39) Eskicioglu C., Kennedy K.J., Droste R.L. Characterization of soluble organic matter of waste activated sludge before and after thermal pretreatment. Water Research 40, 2006, 3725-3736.

40) Eskicioglu C., Kennedy K.J., Droste R.L. Performance of anaerobic waste activated sludge digesters after microwave pretreatment. Water Environment Research 79, 2007, 2265-2273. 
41) Eskicioglu C., Terzian N, Kennedy K.J., Droste L.R., Hamoda M. Athermal microwave effects for enhancing digestibility of waste activated sludge. Water Research 41, 2007, 2457-2466.

42) Eskicioglu C., Prorot A., Marin J., Droste R.L., Kennedy K.J. Synergetic pretreatment of sewage sludge by microwave irradiation in prsence of $\mathrm{H} 2 \mathrm{O} 2$ for enhanced anaerobic digestion. Water Research 42 (18), 2008a, 4674-4682.

43) Eskicioglu C., Kennedy K.J., Droste R.L. Initial examination of microwave pretreatment on primary, secondary and mixed sludges before and after anaerobic digestion. Water Science and Technology 57, 2008b, 311-317.

44) Fisher R.A., Swanwick S.J. High temperature treatment of sewage sludges. Water Pollution and Control, 71(3), 1971, 255-270.

45) Fodor I. A környezetvédelem és regionalitás Magyarországon. Dialóg Campus Kiadó, Budapest, 2001, 384 p.

46) Fujikawa H., Ushioda H., Kudo Y. Kinetics of Escheria coli destruction by microwave irradiation. Applied Environmental Microbiology 58, 1992, 920-924.

47) Ganidi N., Tyrrel S., Cartmell E. Anaerobic digestion foaming causes-a review. Bioresource Technology 100, 2009, 5546-5554.

48) Géczi G., Horváth M., Kaszab T., Alemany G.G. No major differences found between the effects of microwave-based and conventional heat treatment methods on two different liquid foods. PLOS ONE 8(1), 2013, 1-12.

49) George D.F., Bilek M.M., McKenzie D.R. Non-thermal effects int he microwave induced unfolding of proteins observes by chaperone binding. Bioelectromagnetics 29, 2008, 324-330

50) Göllei A., Magyar A., Gerzson M., Ludányi L. Mikrohullámú tápvonalelemek modellezése. Múszaki Kémiai Napok 2010 Konferenciakiadványa, 2010, 40-46.

51) Greffe J.L., Grosse C., Priou A. Dielectric properties of heterogenous materials. In PIER Series, Vol. 6., Ch.:2; Elsevier, New York, 1992, 398 p.

52) Guo L., Li X., Bo X., Yang Q., Zeng G., Liao D., Liu J. Impacts of sterilization, microwave and ultrasonication pretreatment on hydrogen producing using waste sludge. Bioresource Technology 99, 2008, 3651-3658.

53) Hajek M. Microwave Activation of Homogeneous and Heterogeneous Catalytic Reactions. Collection of Czechoslovak Chemical Communications, 62(2), 1997, 347-354.

54) Haque KE. Microwave energy for mineral treatment processes-a brief review. International Journal of Mineral Processing, 57(1), 1999, 1-24.

55) Haug R.T., Stuckey D.C., Gossett J.M., McCarthy P.L. Effects of thermal pre-treatment on digestibility and dewaterability of organic sludges. Journal of Water Pollution Control Federation 50, 1978, 73-85.

56) Haug R.T., LeBrun T.J., Tortorici L.D. Theraml pre-treatment of sludge, a field demonstartion. Journal of Water Pollution Control Federation 55, 1983, 23-34.

57) Herrero M.A., Kremsner J.M., Kappe C.O. Nonthermal microwave effects revisited:ont he importance of internal temperature monitoring and agitation in microwave chemistry. Journal of Organic Chemistry, 73, 2008, 36-47.

58) Hiraoka M., Takeda N., Sakai S., Yasuda A. Highly efficient anaerobic digestion with thermal pre-treatment. Water Science and Technolgy 17, 1985, 529-539.

59) Holtze C,., Sivaramakrishnan R., Antonietti M., Tsowi J., Kremer F., Kramer K.D. The microwave absorption of emulsions containing aqueous micro- and nanodroplets: A menas to optimize microwva heating. Journal of Colloid and Interface Science 302, 2006, 651-657.

60) Holzwarth A., Lou J., Hatton TA., Laibinis PE. Enhanced microwave heating of non-polar solvents by dispersed magnetic nanoparticles. Industrial and Engineering Chemistry Research 37(7), 1998, 2701-2706. 
61) Hong S.M., Park J.K., Teeradej N., Lee Y.O., Cho Y.K., Park C.H. Pretreatment of sludge with microwaves for pathogen destruction and improved anaerobic digestion performance. Water Environmental Research 78(1), 2006, 76-83.

62) Housecroft C.E., Sharpe A.G. Inorganic chemistry 2nd Ed., Pearson Ed. Ltd., 2005, 949 p.

63) Hoz DLA., Diaz-Ortiz A., Moreno A. Selectivity in Organic Synthesis Under Microwave Irradiation. Current Organic Chemistry, 8(10), 2004, 903-918.

64) Iacovidou E., Ohandja D.G., Voulvoulis N. Food waste co-digestion with sewage sludgeRealising its potential in the UK. Journal of Environmental Management 112, 2012, 267-274.

65) Jacob J., Chia LHL., Boey FYC, Review-thermal and non-thermal interaction of microwave radiation with materials. Journal of Materials Science 30(21), 1995, 5321-5327.

66) Jones DA., Lelyveld T.P., Mavrofidis S.D., Kingman S.W., Miles N.J. Microwae heating applications in environmental engineering-areview. Resources, Conservation and Recycling. 34, 2002, 75-90.

67) Kawala Z., Atamanczuk T. Microwave enhanced thermal decontamination of soil. Environmental Science and Technology 32(17), 1998, 2602-2607.

68) Kennedy K.J., Thibault G., Droste R.L. Microwave enhanced digestion of aerobic SBR sludge. Water SA 33(2), 2007, 261-270.

69) Kepp, U., Machenbach I., Weisz N., Solheim O.E. Enhanced stabilization of sewage sludge through thermal hydrolysis 3 years of experience with full scale plant. Water Science and Technology 42(9), 2000, 89-96.

70) Kim h.W., Han S.K., Shin S.H. The optimisation of food waste addition as a co-substrate in anaerobic digestion of sewage sludge. Waste Management Research, 21, 2003, 515-526.

71) Kingman SW., Vorster W., Rowson NA. The influence of mineralogy on microwave assisted grinding. Minerals Engineering 13(3), 1999, 313-327.

72) Komarov V., Wang S., Tang J. Permittivity and measurement. In: Wiley Encyclopedia of RF and Microwave Engineering, Vol.4., Wiley and Sons, Hoboken, 2005, 3694-3711

73) Komarov V. Handbook of dielectricand thermal properties of materials at microwave frequencies. Artech House, US, 2012, 169 p.

74) Kong Y., Cha CY. Reduction of NOX adsorbed on char with microwave energy. Carbon, 34(8), 1996, 1035-1040.

75) Kozempel M., Cook RD., Scullen O.J., Annouos B.A. Development of a process for detecting non-thermal effects of a microwave energy on microorganisms at low temperature. Journal of Food Processing and Preservation 24, 2000, 287-301.

76) Kremer F., Schönhals A. Broadband dielectric spectroscopy. Springer Verlag, BerlinHeidelberg, 2003, 729 p.

77) Kuglarz M., Karakashev D., Angelidaki I. Microwave and thermal pretreatment as methods for increasing the biogas potential of secondary sludge. Bioresource Technology 134, 2013, 290297.

78) Kumar S.B., Matthew K.T., Raveendaranath U., Augustine P. Dielectric properties of certain biological materials at microwave frequencies. International Journal of Microwave Power and EM Energy, 36, 2001, 67-75.

79) Lakatos E., Kovács A.J., Szerencsi Á., Neményi M. Non-thermal effect of microwave treatment on enzyme suspensions Part II.: Cellulose enzyme activity. Review of Faculty of Engineering Analecta technica Szegedinensia, 2009, 63-68.

80) Leadbeater N.E. Microwave heating as a tool for sustainable chemistry. CRC Press, 2011, 278 p. 
81) Lee Y.C., Lo S.L., Chiueh P.T., Chang D.G. Efficient decomposition of perfluorocarboxylic acids in aqueous solution using microwave-induced persulfate. Water Research 43, 2009, 2811-2816.

82) Loupy A., Maurel F., Sabatie-Gogova A. Improvements in Diels-Alder cycloadditions with some acetylenic compounds under solvent-free microwave-assisted conditions: experimental results and theoretical approaches.Tetrahedron, 60(7), 2004, 1683-1691.

83) Lovas M., Kovacova M., Dimitrakis G., Cuvanova S., Znamenackova I., Jakabsky S. Modeling of microwave heating of andesite and minerals. International Journal of Heat and Mass Transfer 53, 2010, 3387-3393.

84) Lucchesi M.E., Smadja J., Bradshow S., Louw W., Chemat F. Solvent free microwave extraction of Ellataria cardamonum L.: a multivariate study of a new technique for the extraction of essential oil. Journal of Food Engineering 79, 2007, 1079-1086.

85) Ludlow-Palafox C., Chase HA. Microwave-induced pyrolysis of plastic wastes. Industrial and Engineering Chemistry Research 40(22), 2001, 4749-4756.

86) Marland S., Han B., Merchant A., Rowson N. The effect of microwave radiation on coal grindability. Fuel 79(11), 2000, 1283-1288.

87) Metaxas AC., Meredith RJ. Industrial microwave heating. Power Engineering Series 4. Peter Peregrinus Ltd. (IEE),., 1993, 376 p.

88) Menendez JA., Menendez EM., Inglesias Mj., Garcia A., Parra, PB., Pis JJ. Thermal treatment of active carbons: a comparison between microwave and electric heating. Journal of Microwave Power and Electromagnetic Energy, 34(3), 1999, 137-140.

89) Menendez J.A., Arenillas A., Fidalgo B., Fernandez Y., Zubizarreta L., Calvo E.G. Bermudez J.M. Review: microwave heating processes involving carbon materials. Fueal Processing Technology 91, 2008, 1-8.

90) Miklavc A. Strong Acceleration of Chemical Reactions Occurring Through the Effects of Rotational Excitation on Collision Geometry. ChemPhysChem, 2(8-9), 2001, 552-555

91) Mottet A., Steyer J.P., Deleris S., Vedrenne F., Chauzy J., Carrere J. Kinetics of thermophilic batch anaerobic digestion of thermal hydrolized waste activetd sludge. Biochemical Engineering Journal 46, 2009, 169-175.

92) Mudhoo A., Moorateeah P., Mohee R. Effects of microwave heating on biogas production, chemycal oxygen demand and volatile solids solubilization of food residues. World Academy of Science, Engineering and Technology 69, 2012, 805-810.

93) Müller J.A. Prospects and problems of sludge pretreatment processes. Water Science and Technology 44(10), 2001, 121-128.

94) Nelson S.O., Forbus J., Lawrence K. Permittivity o fresh fruits and vegetables at 0,2 to $2 \mathrm{GHz}$. Journal of microwave Power and Electromagnetic Energy 29, 1994, 81-93.

95) Nelson S.O. Fundamentals of dielectric properties measurements and agricultural applications. Journal of Microwave Power and electromagnetic Energy 44(2), 2010, 98-113.

96) Neyens E., Baeyens J. A review of thermal sludge pre-treatment processes to improve dewaterability. Journal of Hazardous Materials B(98), 2003, 51-67.

97) Oppermann SH., Brown RC. VOC emission control with polymeric adsorbents and microwave desorption. Pollution Engineering, 31(1), 1999, 58-60.

98) Országh I. Baromfifeldolgozási szennyvíziszap környezeti ártalmának megszüntetése mikrohullámú energiaközléssel. Múszaki Kémiai Napok Konferencia Kiadvány (2004), Veszprém, 117-122 p.

99) Park B., Ahn J.H., Kim J., Hwang S. Use of microwave pretreatment for enhanced anaerobiosos of secondary sludge. Water Science and Technology 50, 2004, 17-23. 
100) Park W.J., Ahn J.H., Hwang S., Lee C.K. Effect of output power, target temperature, and solid concentration ont he solubilization of waste activated sludge using microwave irradiation. Bioresource Technology 101, 2010, S13-S16

101) Pennock S.R., Shepherd P.R. Microwave Engineering. McGraw-Hill Publ. Ltd., 352p.

102) Porcelli M., Cacciapuotia G., Fuscoa S., Massab R., D’Ambriosob G., Bertoldoa C., Rosaa M.D., Zappia V. Non-thermal effects of microwaves on proteins: thermophilic enzymes as modes system. FEBS Letter 402, 1997, 102-106.

103) Pozar D.M. Microwave Engineering. 2nd Ed., John Wiley and Sons, 1998, 716 p.

104) Prorot A., Julien L., Dagot C., Leprat P. Sludge disintegration during heat treatment at low temperature. Biochemical Engineering Journal 54, 2011, 178-184.

105) Qiao W., Wang W., Xun R. Lu WJ., Yin K.Q. Sewage sludge hydrothermal treatment by microwave irradiation combined with alkali addition. Journal of Materials Science 43(7), 2008, 2431-2436.

106) Raner KD., Strauss CR., Trainor RW., Thorn JS. A new microwave reactor for batchwise organic synthesis. Journal of Organic Chemistry 60(8), 1995, 2456-2460

107) Reimbert CG., Minzoni AA., Smyth NF. Effect of radiation losses on hotspot formation and propagation in microwave heating. IMA Journal of Applied Mathematics 57(2), 1996, 165 179.

108) Remya N., Lin J-G. Current status of microwave application in wastewater treatment-A review. Chemical Engineering Journal 166, 2011, 797-813.

109) Saillard R., Poux M., Berlan J. Audhuy-Peaudecerf M. Microwave heating of organic solvents: thermal effects and field modelling. Tetrahedron 51(14), 1995, 4033-4042.

110) Shahriari H., Warith M., Kennedy K.J. Effect of microwave temperature, intensity and moisture content on solubilization of organic fraction of municipal solid waste. International Journal of Environmental Technology and Management, 14(1-4), 2011, 67-83.

111) Shahriari H., Warith M., Hamoda M., Kennedy K.J. Anaerobic digestion of organic fraction of municipal solid waste combining two pretreatment modalities, high temperature microwave and hydrogen peroxide. Waste Management 32, 2012, 41-52.

112) Shamis Y., Patel S., Taube A., Morsi Y., Sbarski I., Shramkov Y., Croft R., Crawford R.J., Ivanova E.P. A new sterilization technique of bovine pericardial biomaterial using microwave radiation. Tissue Engineering Method 15, 2009, 445-454

113) Shamis Y., Mitik-Dineva N., Taube A., Crawford R.J., Ivanoca E.P. A study of the specific electromagnetic effects of microwave radiation on Escherichia coli. Applied Environmental Microbiology 77, 2011, 3017-3022.

114) Shamis Y., Croft R., Taube A., Crawford R.J., Ivanoca E.P. Review of the specific effects of microwave radiation on bacterial cells, Applied Microbiology and Biotechnology 96, 2012a, 319-325

115) Shamis Y., Taube A., Croft R.., Crawford R.J., Ivanoca E.P. Influence of $18 \mathrm{GHz}$ microwave radiation ont he enzymatic activity of Eschericia coli lactate dehydrogenase and cytochrome $\mathrm{c}$ oxidase. Journal of Physics D: Applied Physics 5, 2012b, 13-17.

116) Sólyom K., Mato RB., Perez-Elvira SI., Cocero MJ: The influence of the energy absorbed from microwave pretreatment on biogas production from secondary wastewater sludge. Bioresource Technology 102(23), 2011, 10849-10854.

117) Szabó G., Rajko R., Hodúr C. Combined energy transfer by microwave-convective drying of agriculture materials. Hungarian Agricultural Engineering 11, 1998a, 23-25.

118) Szabó G., Rajkó R., Kovács E., Vidal-Valverde C. Optimisation of microwave treatment for reducing enzyme activity of soya bean. Acta Horticulturae 476, 1998b, 141-147.

119) Tang J., Feng H., Lau M. Microwave heating in food processing. In Yang and Tang eds. Advances in Bioprocessing Engineering Vol.1., World Scientific, London UK, 2002, 173 p. 
120) Tang B., Yu L.F., Huang S.S., Luo J.Z., Zhuo Y. Energy efficinecy of pretreating excess sewage sludge with microwave irradiation. Bioresource Technology 101(14), 2010, 50925097.

121) Toreci I., Kennedy K.J., Droste R.L. Evaluation of continuous mesophilic anaerobic sludge digestion after high temperature microwave pretreatment. Water Resource 43, 2009, 1273 1284.

122) Yang, H.W., Gunsekaran, S. Comparison of temperature distribution in model food cylinders based on Maxwell's eguations and Lambert's law during pulsed microwave heating, Journal of Food Engineering, 64(4), 2004, 445-453.

123) Yang Y., Wang P., Shi S., Liu Y. Microwave enhanced Fenton-like process for the treatment of high concentration pharmaceutical wastewater. Journal of Hazardous Material 168, 2009, 238-245.

124) Yang Q., Yi J.., Jing X., Liu Y., Zeng. Improving disintegration and acidification of waste activated sludge by combined alkaline and microwave pretreatment. Process Safety and Environmental Protection 91, 2013, 521-526.

125) Yu Q., Lei H., Yu G., Feng X., Li Z., Wu Z. Influence of microwave irradiation on sludge dewaterability. Chemical Engineering Journal 155, 2009, 88-93.

126) Yu Q., Lei H.Y., Li Z., Li H.L., Chen K., Zhang X.H., Liang R.L. Physical and chemical properties of waste activated sludge after microwave treatment. Water Resource 44, 2010, 2841-2849.

127) Vass A., Pallai-Varsányi E., Göllei A., Halász L., Solymosi J., Vincze Á. Impregnált aktív szenek mikrohullámú viselkedése I. Hőmérsékleti profilok. Müszaki Kémiai Napok Konferenciakiadványa, 2005, 188-191

128) Vermes L. Hulladékgazdálkodás, hulladékhasznosítás. Mezőgazda Kiadó, Budapest, 2005, $220 \mathrm{p}$.

129) Wang S., Tang J., Cavalierai R.P., Davis D. Differential heating of insects in dried nuts and fruits associated with radio frequency and microwave treatments. Transaction ASAE 46, 2003, 1175-1182.

130) Weng SH., Wang J. Exploration ont he mechanism of coal desulphurisation using microwave irradiation and acid washing method. Fuel Processing Technology 31(3), 1992, 233-240.

131) Wennberg M., Ekvall J., Olsson K., Nyman M. Changes in carbohydrate and glucosinolat composition in white cabbage during blanching and treatment with acetic acid. Food Chemistry 95, 2006, 226-236.

132) Wicks GG., Schulz RL. Microwave remediation of hazardous and radioactive wastes. (WSRC-MS-99-00762 U:S: Patent, 1998)

133) Wojciechowska E. Application of microwaves for sewage sludge conditioning. Water Resource 39, 2005, 4749-4754.

134) Wong W.T., Chan W.I., Liao P.H., Lo K.V., Mavinic D.S. Exploring the role of hydrogenperoxide in the microwave advanced oxidation process: solubilization of ammonia and phosphates. Journal of Environmental Engineering and Science 5(6), 2006, 459-465.

135) Zheng J., Kennedy K.J., Eskicioglu C. Effect of low temperature microwave pretreatment on characteristic and mesophilic digestion of primary slduge. Environmental Technology 30(4), 2009, 319-327.

136) 20/2001 (IV.3.) Kormányrendelet „A szennyvizek és szennyvíziszapok mezőgazdasági felhasználásának és kezelésének szabályairól” 


\section{A DOKTORI ÉRTEKEZÉS ALAPJÁT KÉPEZÖ KÖZLEMÉNYEK}

1) Biogas production of ozone and/or microwave-pretreated canned maize production sludge

Beszédes S., Kertész Sz., László Zs., Szabó G., Hodúr C.

Ozone Science \& Engineering 31(3) (2009) 257-261; IF: 1,252

2) Comparison of the effects of microwave irradiation with different intensities on the biodegradability of sludge from the dairy- and meat-industry

Beszédes S., László Zs., Horváth H. Zs., Szabó G., Hodúr C.

Bioresource Technology 102(2) (2011) 814-821; IF: 4,980

3) Effects of microwave pretreatments on the anaerobic digestion of food industrial sewage sludge

Beszédes S., László Zs., Szabó G., Hodúr C.

Environmental Progress \& Sustainable Energy 30(3) (2011) 486-492; IF: 1,649

4) Microwave enhanced biodegradability of meat processing wastewater sludge

Beszédes S., Ludányi L., Szabó G., Hodúr C.

Environmental Engineering and Management (ISSN: 1582-9596)

Accepted paper (2013 aug.); IF:1,258*

Abstract online elérhetö:

http://omicron.ch.tuiasi.ro/EEMJ/pdfs/accepted/332_46_Beszedes_13.pdf

5) Application of response surface methodology to optimize microwave sludge conditioning for enhanced biogas production

Beszédes S., Ábel M., László Zs., Szabó G., Hodúr C.

Annals of Faculty Engineering Hunedoara-International Journal of Engineering 9(2) (2011) 189-193 (ISSN: 1821-4487)

\section{Egyéb közlemények}

1) The possibilities of bioenergy production from whey Beszédes S., László Zs., Szabó G., Hodúr C.

Journal of Agricultural Science and Technology 4(1) (2010) 62-68 (ISSN: 1939-1250)

2) Berry pectins: Microwave-assisted extraction and rheological properties Bélafi-Bakó K., Cserjési P., Beszédes S., Csanádi Zs., Hodúr C. Food and Bioprocess Technology 5(3) (2012) 1100-1105; IF: 4,115

3) Microwave-assisted extraction of anthocyanins from black currant marc Pap N., Beszédes S., Pongracz E., Myllykoski L., Gábor M., Gyimes E., Hodúr C., Keiski R.L.

Food and Bioprocess Technology 6(10) (2013) 2666-2674; IF: 3,126 
4) Maximum recovery of different types of berry byproducts

Hodúr C., Beszédes S., Kertész Sz., László Zs., Szabó G.

Journal on Processing and Energy in Agriculture 13(4) (2009) 312-314 (ISSN:1821-4487)

5) Enhanced enzymatic saccharification of agri-food sloid wastes by microwave pre-treatment

Beszédes S., Ábel M., szabó G., Hodúr C., László Zs.

Annals of Faculty Engineering Hunedoara-International Journal of Engineering 9(3) (2011) 453-458 (ISSN: 1821-4487)

\section{Konferencia előadások}

1) Increasing of biodegradability and digestibility of dairy sludge by microwave treatment

Beszédes S., László Zs., Szabó G., Hodúr C.

5th International Technical Symposium on Food Processing, Monitoring Technology in Bioprocesses and Food Quality Management (Potsdam, Németország, 2009.08.31-2009.09.02) pp.: 315-323 (ISBN.978-300-028-811-1)

2) Toroid-rezonátor fejlesztése szennyvíziszapok mikrohullámú kondicionálására Beszédes S., Ludányi L., Koltai A., Szabó G.

7. Magyar Szárítási Szimpózium (Gödöllő, Magyarország, 2011.04.07-2011.04.08) pp.:12-13 (ISBN: 978-963-269-212-8)

3) Biogas production from food industry wastewater sludge intensified by microwave irradiation

Beszédes S., Ábel M., László Zs., Szabó G., Hodúr C.

Bioenergy and Other Renewable Energy Technologies and Systems (BRETS 2011): 33 International Symposium of Section IV of CIGR (Bucuresti, Románia, 2011.06.23-2011.06.25) Paper PS307 (8p) (ISBN 978-606-521-686-0)

4) Application of microwave toroidal cavity resonators for conditioning of food industry wastewater sludge

Beszédes S., Ludányi L., Veszelovszki P., Hodúr C., Szabó G.

ISEKI Food 2011 - Bridging Training and Research for Industry and the Wider Community: 2nd International ISEKI Food Conference (Milan, Olaszország, 2011.08.31-2011.09.02) p..170 (ISBN 978-889-059-890-6)

5) Microwave treatment as a tool for enhanced waste valorisation

Beszédes S., Kovács-Veszelovszky P., Ludányi L., Hodúr C., Szabó G.

Synergy in the Technical Development of Agriculture and Food Industry, Abstracts of the II International Conference of the CIGR Hungarian National Committee. (Gödöllö, Magyarország, 2011.10.09-2011.10.15) pp.: 65-71 (ISBN 978-963-269-249-4) 


\section{KÖSZÖNETNYILVÁNÍTÁS}

A doktori munkámhoz kapcsolódó infrastrukturális feltételek folyamatos biztosítása, továbbá a kísérleti munka és az eredmények értékelése és elemzése, valamint a disszertációm készítésében nyújtott segítségéért köszönetemet fejezem ki témavezetőmnek, Dr. Hodúr Cecilia egyetemi tanárnak és társ-témavezetőmnek Dr. Keszthelyi-Szabó Gábor egyetemi tanárnak. Köszönöm nekik, hogy 2002 óta lehetőséget biztosítanak az Intézet és a Kutatócsoport munkájában való részvételre, rendelkezésemre álltak a szakmai problémáim megoldásában, támogattak a tanulmányaim során és a kutató munkám nehézségeiben is.

Köszönetet szeretnék mondani Dr. Ludányi Lajos föiskolai tanárnak, aki a kutatómunkám kezdete óta a mikrohullámú berendezések tervezésében és kivitelezésében, továbbá a mikrohullámú mérési metódusok fejlesztésében a kutatócsoportunk munkáját segíti. Köszönetemet szeretném továbbá kifejezni Dr. László Zsuzsanna egyetemi docensek, aki a szakmai munkámat a kezdetektől támogatta és hathatós segítséget nyújtott a kísérletek tervezése és a módszerfejlesztési feladatok során. Sokat segítettek a problémák megoldásában, és a mindennapok szürkeségeit átvészelni PhD-s „társaim”: Dr. Kertész Szabolcs, Szép Angéla, Ábel Marietta, Kiss Zsolt és Veszelovszki Petra, köszönöm ezt nekik. Továbbá köszönet illeti a Folyamatmérnök Intézet miden kollégáját, mert a munkám során végig segítségemre voltak és elviselték a kísérleteim okozta „kellemetlenségeket”. Továbbá köszönet és hála illeti Krisztát, családomat és barátaimat, akik a nehézségek és kételyeim során mellettem álltak és biztattak.

Köszönetemet fejezem ki a „Jedlik Ányos Doktorjelölti Ösztöndíj a Konvergencia régióban” projekt által nyújtott pénzügyi támogatásért. A kutatás a TÁMOP 4.2.4.A/2-111-2012-0001 Nemzeti Kiválóság Program című kiemelt projekt keretében zajlott. A projekt az Európai Unió támogatásával, az Európai Szociális Alap társfinanszírozásával valósult meg. 